\title{
Igneous Rocks
}

\subsection{Intrusives}

\subsubsection{Overview}

Intrusives in the survey area are mainly formed in the Mesozoic acid to intermediate-acid magmatism, which belongs to the Shunxi-Huzhou tectono-magmatic subbelt, north Zhejiang Province. There are 39 plutons of different sizes in the Anji-Chun'an area and some span the provinces of Zhejiang and Anhui, which are mainly stock and apophysis, followed by bosse and a few batholith. Distribution of the intrusives is closely related to structures, and regional faults and folds axial zone provided space for magmatic emplacement. In addition, the contact zone along the Mesozoic volcanic rock and the Paleozoic sedimentary rock is also a favorable emplacement location. The formation time of intrusives can be roughly divided into the Late Jurassic and Early Cretaceous, the former a total of 13 places accounting for one-third of the total number of plutons, the latter about 26 places accounting for two-thirds of the total number. However, based on the study of modern isotope geochronology, there is no obvious temporal interval between both periods, often in a transitional relationship, indicating that there were frequent magma activities from Late Jurassic to Early Cretaceous in northwestern Zhejiang. Intrusives are mainly distributed in the northern part of the survey area (the Anji-Lin'an belt). The outcroppings are less in the southern part of the survey area (the west Chun'an belt), only a small number of granodiorite plutons, but geophysical exploration data indicate that there may be concealed plutons under the overlying strata. The intrusives in the survey area are mainly granodiorite, monzonitic granite, and syenogranite, etc., and secondly quartz (porphyritic)-syenite and quartz monzonite, etc. Metallogenesis is mainly closely related to granodiorite, monzonitic granite, and syenogranite. The contact zone between plutons and wall rocks often developed alterations such as hornfelsic, silicification, pyritization, skarnization, and marbleization, while alterations such as albitization, potassic, greisenization, and sericitization were usually visible on plutons.

\section{(1) Distribution Characteristics}

In the survey area, the intrusives are widely distributed in large scale, with total outcropping about $254.38 \mathrm{~km}^{2}$, and the area of plutons varies greatly ranging from 0.7 to $84.18 \mathrm{~km}^{2}$ with stock or apophysis occurrence. From north to south and from west to east, there are mainly seven composite plutons: Ma'anshan, Tangshe, Tonglizhuang, Xianxia, Zhinanshan, Dongkeng, and Wushanguan. Among them, Ma'anshan, Tangshe, and Xianxia plutons mainly intruded along the northeast fracture zone or the core of the Nanhua-Cambrian anticlinorium. Tonglizhuang and Wushanguan plutons intruded mainly along the contact zone between the Paleozoic strata and the Mesozoic volcanic rocks, which were under the joint control of nearly EW, NE and NW fractures. Zhinanshan-Dongkeng pluton mainly intruded into the volcanic rocks. All these plutons were affected and damaged by the later NE and NW fracture structures to different degrees. The intrusive distribution, contact relationship, lithology, and rock-formation age of these intrusives are detailed in Table 3.1.

\section{(2) Rock Classification}

During the geological survey on intrusive rocks, the map expression mode of "lithology + grain size structure + age + stage" is used to analyzing and dividing lithological compositions and intrusive periods. First classify lithological categories and then structures, and finally, determine facies-change transitional contact or different periods of intrusive contact according to contact relationship. The results show that in the survey area, the lithology of intrusive rocks is mainly monzonitic granite and syenogranite, followed by syenite, quartz syenite, and quartz diorite. Monzonitic granite mainly has textures such as megacrystic-pegmatitic porphyritic and medium-grained 
Table 3.1 Geological characteristics of intrusives in the survey area

\begin{tabular}{|c|c|c|c|c|c|c|c|}
\hline \multirow[t]{2}{*}{ Name } & \multirow{2}{*}{$\begin{array}{l}\text { Geographical } \\
\text { location }\end{array}$} & \multirow{2}{*}{$\begin{array}{l}\text { Area } \\
\left(\mathrm{km}^{2}\right)\end{array}$} & \multirow[t]{2}{*}{ Geological features } & \multicolumn{2}{|l|}{ Lithological combination } & \multirow{2}{*}{$\begin{array}{l}\text { Zircon U-Pb } \\
\text { age (Ma) }\end{array}$} & \multirow{2}{*}{$\begin{array}{l}\text { Lithologic } \\
\text { symbol }\end{array}$} \\
\hline & & & & Lithology & Mineral assemblage & & \\
\hline \multirow[t]{3}{*}{ Ma'anshan } & \multirow[t]{3}{*}{$\begin{array}{l}\text { Northeast: } \\
119^{\circ} 27^{\prime} 30^{\prime \prime} \\
30^{\circ} 40^{\prime} 00^{\prime \prime} \\
\text { Southwest: } \\
119^{\circ} 25^{\prime} 40^{\prime \prime} \\
30^{\circ} 34^{\prime} 52^{\prime \prime}\end{array}$} & \multirow[t]{3}{*}{83.86} & \multirow{3}{*}{$\begin{array}{l}\text { In the strike of northeast, } \\
\text { distributed in } \\
\text { Shangshanling- } \\
\text { Tongkengcun-Lingxi, its } \\
\text { southeast side contacts by } \\
\text { the NE5 } 0^{\circ}-60^{\circ} \text { faults } \\
\text { with the Paleozoic strata, } \\
\text { the fault occurrence is } \\
300^{\circ}-310^{\circ} \angle 60^{\circ}-80^{\circ} \text {; its } \\
\text { east side from } \\
\text { Longxianshan to } \\
\text { Xiayangcun is } \\
\text { fine-grained syenogranite } \\
\text { and megacrystic } \\
\text { porphyritic monzonitic } \\
\text { granite, in intrusive } \\
\text { contact with the } \\
\text { Ordovician strata; the } \\
\text { border in the northeast } \\
\text { side is not seen in the } \\
\text { survey area, and based on } \\
\text { previous study, it is in } \\
\text { intrusive contact with the } \\
\text { Silurian strata, and the } \\
\text { contact surface } \\
\text { occurrence is } 300^{\circ}- \\
340^{\circ} \angle 70^{\circ}-80^{\circ}, \text { locally in } \\
\text { fault contact, and the } \\
\text { contact surface between } \\
\text { plutons and strata has } \\
\text { hornfelsic alteration }\end{array}$} & $\begin{array}{l}\text { Pegmatitic porphyritic } \\
\text { monzonitic granite }\end{array}$ & $\begin{array}{l}\text { Quartz } 35 \%, \text { K-feldspar } \\
50 \% \text {, plagioclase } 15 \% \text {, a } \\
\text { few biotite, and } \\
\text { hornblende, etc., apatite } \\
\text { and zircon occasionally } \\
\text { seen; minerals grain size } \\
\text { was generally <2 mm; } \\
\text { quartz is in the anhedral } \\
\text { granular shape, feldspar } \\
\text { in the shape of block and } \\
\text { strip, quartz and feldspar } \\
\text { are distributed alternately } \\
\text { in equal size }\end{array}$ & $\begin{array}{l}132.2 \pm 1.6 \\
\text { SHRIMP }\end{array}$ & $\eta \gamma^{(\mathrm{W})} \mathrm{K}_{1}^{2}$ \\
\hline & & & & $\begin{array}{l}\text { Phenocryst-porphyritic } \\
\text { monzonitic granite }\end{array}$ & $\begin{array}{l}\text { Phenocryst: plagioclase } \\
5-8 \%, \mathrm{~K} \text {-feldspar } 2-7 \% \text {, } \\
\text { quartz } 2 \% \text {, with grain size } \\
\text { of } 1-3 \mathrm{~cm} \text {; matrix: quartz } \\
25 \%, \mathrm{~K} \text {-feldspar } 20 \%, \\
\text { plagioclase } 20 \% \text {, biotite } \\
10-20 \% \text {, a handful of } \\
\text { hornblende and metallic } \\
\text { minerals, with grain size } \\
\text { of } 2-5 \mathrm{~mm} \text { in general, } \\
\text { and }>5 \mathrm{~mm} \text { for a handful }\end{array}$ & $\begin{array}{l}127.7 \pm 1.2 \\
\text { SHRIMP }\end{array}$ & $\eta \gamma^{(\mathrm{G})} \mathrm{K}_{1}^{2}$ \\
\hline & & & & $\begin{array}{l}\text { Fine-grained } \\
\text { syenogranite }\end{array}$ & $\begin{array}{l}\text { Phenocryst: plagioclase } \\
5-10 \%, \mathrm{~K} \text {-feldspar } 2- \\
4 \% \text {, and a handful of } \\
\text { quartz } 3-5 \% \text {, generally } \\
\text { the grain size }>3 \mathrm{~cm} \text {; } \\
\text { matrix: quartz } 25 \% \text {, } \\
\text { K-feldspar } 20 \% \text {, } \\
\text { plagioclase } 20 \% \text {, biotite } \\
10-20 \% \text {, a handful of } \\
\text { hornblende } 1-2 \% \text {, and } \\
\text { the grain size is } 3-8 \mathrm{~mm}\end{array}$ & $\begin{array}{l}128.3 \pm 1.1 \\
\text { SHRIMP }\end{array}$ & $\gamma^{(\mathrm{x})} \mathrm{K}_{1}^{2}$ \\
\hline \multirow[t]{2}{*}{ Tangshe } & \multirow[t]{2}{*}{$\begin{array}{l}\text { North: } 119^{\circ} \\
19^{\prime} 20^{\prime \prime} \\
30^{\circ} 32^{\prime} 09^{\prime \prime} \\
\text { East: } 119^{\circ} 21^{\prime} \\
10^{\prime \prime} \\
30^{\circ} 31^{\prime} 02^{\prime \prime} \\
\text { Southwest: } \\
119^{\circ} 15^{\prime} 57^{\prime \prime} \\
30^{\circ} 29^{\prime} 34^{\prime \prime}\end{array}$} & \multirow[t]{2}{*}{18.90} & \multirow{2}{*}{$\begin{array}{l}\text { In the strike of northeast, } \\
\text { intruded in the anticline } \\
\text { core. The north part of the } \\
\text { medium-coarse-grained } \\
\text { syenogranite in Bijia } \\
\text { Mount-Tali Mount is in } \\
\text { intrusive contact with the } \\
\text { Nanhua-Sinian strata, the } \\
\text { contact zone has } \\
\text { developed strong } \\
\text { skarnization and } \\
\text { hornfelsic, with the dip } \\
\text { angle of } 60^{\circ}-80^{\circ} \text {; } \\
\text { medium-grained } \\
\text { monzonitic granite in } \\
\text { Nanshan-Tangshe, in its } \\
\text { south is in intrusive } \\
\text { contact with the Nanhua- } \\
\text { Cambrian strata, the } \\
\text { contact zone has } \\
\text { developed hornfelsic, or } \\
\text { locally strong }\end{array}$} & $\begin{array}{l}\text { Medium-grained } \\
\text { monzonitic granite }\end{array}$ & $\begin{array}{l}\text { Quartz } 20 \% \text {, } \\
\text { K-Na-feldspar } 30 \% \text {, } \\
\text { plagioclase } 35 \% \text {, biotite } \\
5-10 \% \text {, hornblende } 5 \% \text {, a } \\
\text { handful of pyrite, and } \\
\text { magnetite, etc., zircon } \\
\text { and apatite visible } \\
\text { occasionally; minerals } \\
\text { have smaller grain sizes, } \\
\text { generally } 2-3 \text { mm or few } \\
0.5-2 \text { mm }\end{array}$ & $\begin{array}{l}140.9 \pm 3.4 \\
\text { LA-ICP-MS }\end{array}$ & $\eta \gamma^{(\mathrm{z})} \mathrm{K}_{1}^{1}$ \\
\hline & & & & $\begin{array}{l}\text { Medium-coarse-grained } \\
\text { syenogranite }\end{array}$ & $\begin{array}{l}\text { K-feldspar } 40 \% \text {, } \\
\text { plagioclase } 15 \% \text {, quartz } \\
30 \% \text {, biotite } 5-10 \% \text {, } \\
\text { hornblende } 3 \% \text {, a handful } \\
\text { of metallic minerals, and } \\
\text { zircon occasionally seen; } \\
\text { minerals have a bigger } \\
\text { grain size, generally } 3- \\
9 \text { mm, up to } 1-2 \mathrm{~cm} \text { for } \\
\text { some K-feldspar }\end{array}$ & $\begin{array}{l}132.2 \pm 1.6 \\
\text { LA-ICP-MS }\end{array}$ & $\gamma^{(\mathrm{c})} \mathrm{K}_{1}^{2}$ \\
\hline
\end{tabular}


Table 3.1 (continued)

\begin{tabular}{|c|c|c|c|c|c|c|c|}
\hline \multirow[t]{2}{*}{ Name } & \multirow{2}{*}{$\begin{array}{l}\text { Geographical } \\
\text { location }\end{array}$} & \multirow{2}{*}{$\begin{array}{l}\text { Area } \\
\left(\mathrm{km}^{2}\right)\end{array}$} & \multirow[t]{2}{*}{ Geological features } & \multicolumn{2}{|l|}{ Lithological combination } & \multirow{2}{*}{$\begin{array}{l}\text { Zircon U-Pb } \\
\text { age (Ma) }\end{array}$} & \multirow{2}{*}{$\begin{array}{l}\text { Lithologic } \\
\text { symbol }\end{array}$} \\
\hline & & & & Lithology & Mineral assemblage & & \\
\hline & & & $\begin{array}{l}\text { skarnization; in the } \\
\text { southeast side of main }\end{array}$ & & $\begin{array}{l}\text { and }>3 \mathrm{~cm} \text { for a handful } \\
\text { of them }\end{array}$ & & \\
\hline & & & $\begin{array}{l}\text { pluton, there are } \\
\text { developed small stocks } \\
\text { such as medium-grained } \\
\text { syenogranite, fine-grained } \\
\text { syenogranite, and } \\
\text { fine-grained monzonitic } \\
\text { granite }\end{array}$ & $\begin{array}{l}\text { Fine-grained } \\
\text { syenogranite }\end{array}$ & $\begin{array}{l}\text { Quartz } 30 \%, \mathrm{~K}- \\
\text { Na-feldspar } 45 \% \text {, } \\
\text { plagioclase } 20 \% \text {, biotite } \\
5 \% \text {, a handful of metallic } \\
\text { minerals, zircon, and } \\
\text { apatite occasionally seen; } \\
\text { general grain size is } 0.5- \\
2 \mathrm{~mm} \text {, and a handful of } \\
\text { grain size up to } 2-3 \mathrm{~mm}\end{array}$ & $\begin{array}{l}125.0 \pm 2.0 \\
\text { LA-ICP-MS }\end{array}$ & $\gamma^{(\mathrm{x})} \mathrm{K}_{1}^{2}$ \\
\hline \multirow[t]{3}{*}{ Tonglizhuang } & \multirow[t]{3}{*}{$\begin{array}{l}\text { North: } 119^{\circ} \\
29^{\prime} 44^{\prime \prime} \\
30^{\circ} 30^{\prime} 40^{\prime \prime} \\
\text { South: } 119^{\circ} \\
28^{\prime} 56^{\prime \prime} \\
30^{\circ} 29^{\prime} 57^{\prime \prime}\end{array}$} & \multirow[t]{3}{*}{1.54} & \multirow{3}{*}{$\begin{array}{l}\text { It partially outcrops near } \\
\text { Baofu Town in the survey } \\
\text { area. Fine-grained } \\
\text { syenogranite at the north } \\
\text { side of the pluton is in } \\
\text { intrusive contact with the } \\
\text { Cambrian-Ordovician } \\
\text { strata, the contact surface } \\
\text { occurrence is } 300^{\circ}- \\
330^{\circ} \angle 60^{\circ}-80^{\circ} \text { and it has } \\
\text { developed hornfelsic } \\
\text { alteration. In the south } \\
\text { side of the pluton at } \\
\text { Shimendong, } \\
\text { medium-coarse-grained } \\
\text { porphyritic quartz syenite } \\
\text { is in intrusive contact } \\
\text { with the first member of } \\
\text { the Huangian Formation } \\
\text { volcanic strata. The } \\
\text { medium-grained } \\
\text { monzonitic granite in the } \\
\text { southeast side also } \\
\text { intrude into the first } \\
\text { member of the Early } \\
\text { Cretaceous Huangjian } \\
\text { Formation, with the } \\
\text { intrusive contact surface } \\
\text { occurrence of } 320^{\circ} \angle 70^{\circ}\end{array}$} & $\begin{array}{l}\text { Coarse-medium-grained } \\
\text { porphyritic quartz } \\
\text { syenite }\end{array}$ & $\begin{array}{l}\text { Phenocryst: } \mathrm{K}- \\
\text { Na-feldspar } 25 \% \text {, } \\
\text { plagioclase } 5 \% \text {, and } \\
\text { dark-colored minerals } \\
2 \% \text {, minerals have bigger } \\
\text { grain sizes, generally } \\
\text { over } 2 \mathrm{~mm} \text {, even up to } 6- \\
7 \mathrm{~mm} \text { individually; a } \\
\text { handful of plagioclase } \\
\text { phenocryst has eroded } \\
\text { into clay minerals. } \\
\text { Matrix: feldspar } 48 \% \text { and } \\
\text { quartz } 12 \% \text {, with grain } \\
\text { size below } 0.5 \text { mm in } \\
\text { general }\end{array}$ & $\begin{array}{l}126.0 \pm 3.0 \\
\text { LA-ICP-MS }\end{array}$ & $\xi_{o}{ }^{(\mathrm{z})} \mathrm{K}_{1}^{3}$ \\
\hline & & & & $\begin{array}{l}\text { Fine-grained } \\
\text { syenogranite }\end{array}$ & $\begin{array}{l}\text { K-feldspar } 40-50 \% \text {, } \\
\text { plagioclase } 20-25 \% \text {, } \\
\text { quartz } 20-30 \% \text {, and a } \\
\text { handful of biotite } 5 \% \text {, } \\
\text { with grain size of } 0.2- \\
1 \mathrm{~mm} \text {; K-feldspar is } \\
\text { mainly orthoclase, wide } \\
\text { plate euhedral crystal, } \\
\text { Carlsbad twin visible in } \\
\text { some of them; plagioclase } \\
\text { is in the shape of } \\
\text { subhedral wide plate and } \\
\text { plate-column, albite } \\
\text { bicrystal visible in some } \\
\text { of them }\end{array}$ & About 130 & $\gamma^{(\mathrm{x})} \mathrm{K}_{1}^{2}$ \\
\hline & & & & $\begin{array}{l}\text { Medium-grained } \\
\text { monzonitic granite }\end{array}$ & $\begin{array}{l}\text { Quartz } 25 \%, \mathrm{~K}- \\
\text { Na-feldspar } 30 \% \text {, } \\
\text { plagioclase } 30 \% \text {, biotite } \\
5-10 \% \text {, hornblende } 5 \% \text {, } \\
\text { zircon and apatite } \\
\text { occasionally seen; grain } \\
\text { size is } 2-3 \mathrm{~mm} \text { and a } \\
\text { handful of } 1-2 \mathrm{~mm}\end{array}$ & $\begin{array}{l}142.3 \pm 1.8 \\
\text { LA-ICP-MS }\end{array}$ & $\eta \gamma^{(\mathrm{z})} \mathrm{K}_{1}^{1}$ \\
\hline $\begin{array}{l}\text { Zhinan } \\
\text { Mount }\end{array}$ & $\begin{array}{l}119^{\circ} 34^{\prime} 22^{\prime \prime} \\
30^{\circ} 22^{\prime} 10^{\prime \prime}\end{array}$ & 0.7 & $\begin{array}{l}\text { The NW-strike small } \\
\text { apophysis intruded in the } \\
\text { rhyolitic tuff lava of the } \\
\text { second member of the } \\
\text { Huangjian Formation, } \\
\text { about } 1 \mathrm{~km} \text { long and } \\
700 \mathrm{~m} \text { wide }\end{array}$ & $\begin{array}{l}\text { Medium-grained quartz } \\
\text { diorite }\end{array}$ & $\begin{array}{l}\text { Quartz } 22 \%, \mathrm{~K}- \\
\text { Na-feldspar } 5 \% \text {, } \\
\text { plagioclase } 50 \% \text {, } \\
\text { hornblende } 20 \% \text {; } \\
\text { minerals' grain size is } \\
\text { generally } 0.4-3 \mathrm{~mm} \text {. } \\
\text { Quartz is granular and } \\
\text { distributed pretty evenly; } \\
\text { plagioclase is } \\
\text { plate-column, most } \\
\text { weathered, based on the } \\
\text { refractive index it is } \\
\text { mainly andesine- } \\
\text { oligoclase; hornblende is } \\
\text { column }\end{array}$ & $\begin{array}{l}130.5 \pm 1.7 \\
\text { LA-ICP-MS }\end{array}$ & $\delta \mathrm{o}^{(\mathrm{z})} \mathrm{K}_{1}^{3}$ \\
\hline
\end{tabular}


Table 3.1 (continued)

\begin{tabular}{|c|c|c|c|c|c|c|c|}
\hline \multirow[t]{2}{*}{ Name } & \multirow{2}{*}{$\begin{array}{l}\text { Geographical } \\
\text { location }\end{array}$} & \multirow{2}{*}{$\begin{array}{l}\text { Area } \\
\left(\mathrm{km}^{2}\right)\end{array}$} & \multirow[t]{2}{*}{ Geological features } & \multicolumn{2}{|l|}{ Lithological combination } & \multirow{2}{*}{$\begin{array}{l}\text { Zircon U-Pb } \\
\text { age (Ma) }\end{array}$} & \multirow{2}{*}{$\begin{array}{l}\text { Lithologic } \\
\text { symbol }\end{array}$} \\
\hline & & & & Lithology & Mineral assemblage & & \\
\hline \multirow[t]{5}{*}{ Xianxia } & \multirow[t]{5}{*}{$\begin{array}{l}\text { Northeast: } \\
119^{\circ} 25^{\prime} 43^{\prime \prime} \\
30^{\circ} 29^{\prime} 20^{\prime \prime} \\
\text { Southwest: } \\
119^{\circ} 15^{\prime} 05^{\prime \prime} \\
30^{\circ} 20^{\prime} 18^{\prime \prime}\end{array}$} & \multirow[t]{5}{*}{84.18} & \multirow{5}{*}{$\begin{array}{l}\text { In the NE-strike, it } \\
\text { spreads in Xianxia- } \\
\text { Zhangcun, the southeast } \\
\text { side of the pluton is } \\
\text { mainly in NE } 30^{\circ}-40^{\circ} \\
\text { fault contact with the } \\
\text { Paleozoic strata, with the } \\
\text { occurrence of } 320^{\circ}- \\
330^{\circ} \angle 60^{\circ}-80^{\circ} \text {, and } \\
\text { locally intruded into the } \\
\text { Cambrian-Ordovician } \\
\text { strata; its northwest side } \\
\text { is in intrusive contact } \\
\text { with the Nanhua- } \\
\text { Ordovician strata, with } \\
\text { the contact surface } \\
\text { occurrence of } 310^{\circ}- \\
350^{\circ} \angle 60^{\circ}-90^{\circ} \text { and fault } \\
\text { contact exists locally }\end{array}$} & $\begin{array}{l}\text { Medium-coarse-grained } \\
\text { quartz syenite }\end{array}$ & $\begin{array}{l}\text { K-Na-feldspar } 85 \% \text {, } \\
\text { plagioclase } 10 \% \text {, quartz } \\
5 \% \text {, biotite } 5-10 \% \text {; grain } \\
\text { size is } 3-10 \mathrm{~mm} \text {, and a } \\
\text { handful of minerals' grain } \\
\text { size is up to } 1 \mathrm{~cm} \text {; quartz } \\
\text { is granular; feldspar is } \\
\text { mostly plate and short } \\
\text { strip, locally is arranged } \\
\text { directionally, and } \\
\text { individual plagioclase } 1- \\
2 \mathrm{~cm}\end{array}$ & $\begin{array}{l}\text { About } \\
130 \mathrm{Ma}\end{array}$ & $\xi_{o}{ }^{(\mathrm{c})} \mathrm{K}_{1}^{3}$ \\
\hline & & & & $\begin{array}{l}\text { Fine-grained } \\
\text { syenogranite }\end{array}$ & $\begin{array}{l}\text { Quartz 30\%, K-feldspar } \\
55 \% \text {, plagioclase } 10 \% \text {, } \\
\text { biotite 5\%; grain size } \\
0.5-2 \mathrm{~mm}\end{array}$ & $\begin{array}{l}132.4 \pm 2.4 \\
\text { LA-ICP-MS }\end{array}$ & $\gamma^{(\mathrm{x})} \mathrm{K}_{1}^{2}$ \\
\hline & & & & $\begin{array}{l}\text { Medium-coarse-grained } \\
\text { and } \\
\text { coarse-medium-grained } \\
\text { syenogranite }\end{array}$ & $\begin{array}{l}\text { Quartz } 30 \% \text {, K-feldspar } \\
45 \% \text {, plagioclase } 20 \% \text {, } \\
\text { biotite }(5 \%) \text {; grain size } \\
\text { generally } 5-10 \mathrm{~mm} \text { for } \\
\text { internal-facies minerals } \\
\text { and up to } 2 \mathrm{~cm} \text { for a few, } \\
\text { and locally it becomes } \\
\text { medium-coarse-grained } \\
\text { syenogranite, the grain } \\
\text { size of margin minerals is } \\
3-6 \mathrm{~mm}\end{array}$ & $\begin{array}{l}132.9 \pm 3.3 \\
\text { LA-ICP-MS }\end{array}$ & $\gamma^{(\mathrm{c}) /(\mathrm{z})} \mathrm{K}_{1}^{2}$ \\
\hline & & & & $\begin{array}{l}\text { Phenocryst and } \\
\text { medium-coarse-grained } \\
\text { porphyritic monzonitic } \\
\text { granite }\end{array}$ & $\begin{array}{l}\text { Phenocryst: feldspar and } \\
\text { quartz, in the content of } \\
10-15 \% \text {, grain size up to } \\
1-3 \mathrm{~cm} \text {; Matrix: quartz } \\
20 \% \text {, K-Na-feldspar } \\
20 \% \text {, plagioclase } 30 \% \text {, } \\
\text { biotite } 5-10 \% \text {, } \\
\text { hornblende } 5 \% \text { the grain } \\
\text { size is } 2-5 \mathrm{~mm} \text {, } \\
\text { occasionally } 5-8 \mathrm{~mm}\end{array}$ & $\begin{array}{l}144.2 \pm 1.0 \\
\text { SHRIMP }\end{array}$ & $\begin{array}{l}\eta \gamma^{(\mathrm{G}) /(\mathrm{c})} \\
\mathrm{K}_{1}^{1}\end{array}$ \\
\hline & & & & $\begin{array}{l}\text { Medium- and } \\
\text { fine-grained (porphyritic) } \\
\text { monzonitic granite }\end{array}$ & $\begin{array}{l}\text { Quartz } 15 \% \text {, K-feldspar } \\
30 \% \text {, plagioclase } 40 \% \text {, } \\
\text { biotite } 5-10 \% \text {, } \\
\text { hornblende } 5 \% \text {; minerals' } \\
\text { grain size is generally } 2- \\
5 \mathrm{~mm} \text {, a handful of } \\
\text { plagioclase is bigger in } \\
\text { grain size, up to about } \\
1 \mathrm{~cm} \text { and dark-colored } \\
\text { minerals increased in the } \\
\text { margin of the pluton }\end{array}$ & $\begin{array}{l}145.1 \pm 1.2 \\
\text { SHRIMP }\end{array}$ & $\eta \gamma^{(\mathrm{z})} \mathrm{K}_{1}^{1}$ \\
\hline \multirow[t]{2}{*}{ Wushanguan } & \multirow[t]{2}{*}{$\begin{array}{l}\text { Northwest: } \\
119^{\circ} 38^{\prime} 04^{\prime \prime} \\
30^{\circ} 29^{\prime} 59^{\prime \prime} \\
\text { Southwest: } \\
119^{\circ} 36^{\prime} 38^{\prime \prime} \\
30^{\circ} 25^{\prime} 03^{\prime \prime} \\
\text { Southeast: } \\
119^{\circ} 43^{\prime} 18^{\prime \prime} \\
30^{\circ} 24^{\prime} 29^{\prime \prime}\end{array}$} & \multirow[t]{2}{*}{64.00} & \multirow[t]{2}{*}{$\begin{array}{l}\text { It spreads in the } \\
\mathrm{NW} \text {-strike, its west side } \\
\text { is mainly in fault contact } \\
\text { with the Huangjian } \\
\text { Formation volcanic strata, } \\
\text { the fault's strike is NW } \\
320^{\circ}-330^{\circ} \text { and NE } 40^{\circ} \text {, it } \\
\text { dips toward southwest } \\
\text { and northwest, its dip } \\
\text { angle varies between } \\
65^{\circ}-80^{\circ} \text {; locally in } \\
\text { intrusive contact with } \\
\text { volcanic strata (or the } \\
\text { Cambrian Yangliugang } \\
\text { Formation). Its northeast }\end{array}$} & $\begin{array}{l}\text { Coarse-medium-grained } \\
\text { syenite }\end{array}$ & $\begin{array}{l}\mathrm{K}-\mathrm{Na} \text {-feldspar } 85 \% \text {, } \\
\text { plagioclase } 10 \% \text {, quartz } \\
5 \% \text {, biotite } 5-10 \% \text {; the } \\
\text { grain size is } 3-8 \mathrm{~mm} \text {, but } \\
\text { up to } 1 \mathrm{~cm} \text { for a handful } \\
\text { of minerals; quartz is } \\
\text { granular; feldspar is } \\
\text { mostly plate and locally } \\
\text { short strip, it is arranged } \\
\text { directionally, and } \\
\text { individual plagioclase } 1- \\
2 \mathrm{~cm}\end{array}$ & About 130 & $\xi^{(\mathrm{z})} \mathrm{K}_{1}^{3}$ \\
\hline & & & & $\begin{array}{l}\text { (Porphyritic) } \\
\text { fine-grained syenogranite }\end{array}$ & $\begin{array}{l}\text { K-feldspar 60-65\%, } \\
\text { quartz } 25-35 \%\end{array}$ & $\begin{array}{l}128.1 \pm 0.82 \\
\text { SHRIMP }\end{array}$ & $\gamma^{(\mathrm{x})} \mathrm{K}_{1}^{2}$ \\
\hline
\end{tabular}


Table 3.1 (continued)

\begin{tabular}{|c|c|c|c|c|c|c|c|}
\hline \multirow[t]{2}{*}{ Name } & \multirow{2}{*}{$\begin{array}{l}\text { Geographical } \\
\text { location }\end{array}$} & \multirow{2}{*}{$\begin{array}{l}\text { Area } \\
\left(\mathrm{km}^{2}\right)\end{array}$} & \multirow[t]{2}{*}{ Geological features } & \multicolumn{2}{|l|}{ Lithological combination } & \multirow{2}{*}{$\begin{array}{l}\text { Zircon U-Pb } \\
\text { age (Ma) }\end{array}$} & \multirow{2}{*}{$\begin{array}{l}\text { Lithologic } \\
\text { symbol }\end{array}$} \\
\hline & & & & Lithology & Mineral assemblage & & \\
\hline & & & \multirow{4}{*}{$\begin{array}{l}\text { and south sides are in } \\
\text { intrusive contact with the } \\
\text { Huangjian Formation } \\
\text { volcanic strata; its } \\
\text { southeast side is in } \\
\text { intrusive contact with the } \\
\text { Cambrian strata, the } \\
\text { intrusive contact surface } \\
\text { is not constant in attitude } \\
\text { and dip, with dip angle of } \\
60^{\circ}-90^{\circ}, \text { and hornfelsic } \\
\text { and skarnization are often } \\
\text { seen near the intrusive } \\
\text { contact zone }\end{array}$} & & $\begin{array}{l}\text { plagioclase } 5-10 \% \text {; the } \\
\text { grain size is mainly fine, } \\
\text { about } 0.5-1.5 \mathrm{~mm}\end{array}$ & & \\
\hline & & & & $\begin{array}{l}\text { Phenocryst-porphyritic } \\
\text { monzonitic granite }\end{array}$ & $\begin{array}{l}\text { Phenocryst: feldspar and } \\
\text { quartz, in the content of } \\
10-15 \% \text {, grain size up to } \\
1-3 \mathrm{~cm} \text {; matrix: quartz } \\
20 \% \text {, K-Na-feldspar } \\
20 \% \text {, plagioclase } 30 \% \text {, } \\
\text { biotite } 5-10 \% \text {, } \\
\text { hornblende } 5 \% \text {, the grain } \\
\text { size is generally } 2-5 \mathrm{~mm} \text {, } \\
\text { occasionally } 5-8 \mathrm{~mm}\end{array}$ & About 130 & $\eta \gamma^{(\mathrm{G})} \mathrm{K}_{1}^{2}$ \\
\hline & & & & $\begin{array}{l}\text { Medium-coarse- and } \\
\text { medium-grained } \\
\text { syenogranite }\end{array}$ & $\begin{array}{l}\text { K-feldspar } 45-55 \% \text {, } \\
\text { plagioclase } 15-25 \% \text {, } \\
\text { quartz } 25-35 \% \text {, biotite } \\
1 \% \text {; the grain size is } 2- \\
7 \mathrm{~mm} \text { with few } 7- \\
10 \mathrm{~mm} \text {, and locally, } \\
\mathrm{K} \text {-feldspar is } \\
\text { approximately } \\
\text { porphyritic }(1- \\
2 \mathrm{~cm} \times 1-1.5 \mathrm{~cm}) \text {; from } \\
\text { southeast to northwest, it } \\
\text { evolves from } \\
\text { medium-coarse-grained } \\
\text { to } \\
\text { coarse-medium-grained }\end{array}$ & $\begin{array}{l}132.0 \pm 3.0 \\
\text { LA-ICP-MS }\end{array}$ & $\gamma^{(\mathrm{z})} \mathrm{K}_{1}^{2}$ \\
\hline & & & & $\begin{array}{l}\text { Medium-grained } \\
\text { monzonitic granite }\end{array}$ & $\begin{array}{l}\text { Quartz } 20-30 \% \text {, } \\
\text { K-feldspar } 15-30 \%, \\
\text { plagioclase } 30-40 \% \text {, } \\
\text { biotite } 2-6 \% \text {, very few } \\
\text { zircon and apatite; the } \\
\text { grain size is } 0.5-4 \mathrm{~mm} \text {. } \\
\text { Inside the lithology there } \\
\text { are developed mafic } \\
\text { micro-granular enclaves } \\
\text { (MMEs) such as biotite } \\
\text { or biotite, plagioclase, in } \\
\text { the ellipse, long strip and } \\
\text { irregular shapes, in the } \\
\text { sized of } 1-30 \mathrm{~cm}\end{array}$ & $\begin{array}{l}136.3 \pm 1.2 \\
\text { SHRIMP }\end{array}$ & $\eta \gamma^{(\mathrm{z})} \mathrm{K}_{1}^{1}$ \\
\hline \multirow[t]{2}{*}{ Dongkeng } & \multirow[t]{2}{*}{$\begin{array}{l}119^{\circ} 35^{\prime} 34^{\prime \prime} \\
30^{\circ} 24^{\prime} 02^{\prime \prime}\end{array}$} & \multirow[t]{2}{*}{1.2} & \multirow[t]{2}{*}{$\begin{array}{l}\text { Ellipse-like small } \\
\text { apophysis in NEE strike, } \\
\text { intruded in the contact } \\
\text { zone between the } \\
\text { second-third member of } \\
\text { the Huangjian Formation, } \\
\text { from outside to inside } \\
\text { they are } \\
\text { coarse-medium-grained } \\
\text { quartz monzonite, } \\
\text { medium-coarse-grained } \\
\text { syenogranite, and } \\
\text { fine-grained syenogranite }\end{array}$} & $\begin{array}{l}\text { Fine-grained } \\
\text { (porphyritic) } \\
\text { syenogranite }\end{array}$ & $\begin{array}{l}\text { Phenocryst: } \mathrm{K}- \\
\text { Na-feldspar } 10 \% \text {, } \\
\text { plagioclase } 4 \% \text {; the grain } \\
\text { size is } 0.1-1 \mathrm{~mm} \text { and } \\
0.5-2 \mathrm{~mm} \text {, but } 2-6 \mathrm{~mm} \\
\text { for very few of it; matrix: } \\
\mathrm{K}-\mathrm{Na}-\mathrm{feldspar} 46 \% \text {, } \\
\text { plagioclase } 8 \% \text {, quartz } \\
30 \% \text {, a handful of } \\
\text { metallic minerals, and the } \\
\text { grain size is } 0.1-1 \mathrm{~mm}\end{array}$ & $\begin{array}{l}127.6 \pm 1.2 \\
\text { LA-ICP-MS }\end{array}$ & $\gamma^{(\mathrm{x})} \mathrm{K}_{1}^{3}$ \\
\hline & & & & $\begin{array}{l}\text { Medium-coarse-grained } \\
\text { syenogranite }\end{array}$ & $\begin{array}{l}\text { Quartz } 40 \%, \mathrm{~K}- \\
\text { Na-feldspar } 54 \% \text {, } \\
\text { plagioclase } 6 \% \text {, a handful } \\
\text { of biotite; the grain size is } \\
3-8 \mathrm{~mm} \text {, and } 8-12 \mathrm{~mm} \\
\text { for a handful }\end{array}$ & $\begin{array}{l}127.9 \pm 1.3 \\
\text { LA-ICP-MS }\end{array}$ & $\gamma^{(\mathrm{c})} \mathrm{K}_{1}^{3}$ \\
\hline
\end{tabular}


Table 3.1 (continued)

\begin{tabular}{|c|c|c|c|c|c|c|c|}
\hline \multirow[t]{2}{*}{ Name } & \multirow{2}{*}{$\begin{array}{l}\text { Geographical } \\
\text { location }\end{array}$} & \multirow{2}{*}{$\begin{array}{l}\text { Area } \\
\left(\mathrm{km}^{2}\right)\end{array}$} & \multirow[t]{2}{*}{ Geological features } & \multicolumn{2}{|c|}{ Lithological combination } & \multirow{2}{*}{$\begin{array}{l}\text { Zircon U-Pb } \\
\text { age (Ma) }\end{array}$} & \multirow{2}{*}{$\begin{array}{l}\text { Lithologic } \\
\text { symbol }\end{array}$} \\
\hline & & & & Lithology & Mineral assemblage & & \\
\hline & & & & $\begin{array}{l}\text { Fine-medium-grained } \\
\text { porphyritic quartz } \\
\text { monzonite }\end{array}$ & $\begin{array}{l}\text { Phenocryst: quartz (very } \\
\text { few), plagioclase } 20 \% \text {, } \\
\mathrm{K}-\mathrm{Na} \text {-feldspar } 8 \% \text {, } \\
\text { hornblende } 4 \% \text {; the grain } \\
\text { size is generally } 1-3 \mathrm{~mm} \text {, } \\
\text { few } 3-4 \mathrm{~mm} \text {; matrix: } \\
\text { quartz } 12 \%, \mathrm{~K}- \\
\text { Na-feldspar } 35 \% \text {, } \\
\text { plagioclase } 20 \% \text {, and the } \\
\text { grain size is generally } \\
0.2-0.5 \mathrm{~mm}\end{array}$ & About 130 & $\eta \mathrm{o}^{(\mathrm{z})} \mathrm{K}_{1}^{3}$ \\
\hline
\end{tabular}

(porphyritic) and fine-grained; syenogranite mainly has textures such as coarse-grained, medium-coarse-grained, coarse-medium-grained, medium-grained, and fine-grained; (quartz) syenite is mainly medium-coarse-grained and coarse-medium-grained texture; and quartz diorite is mainly medium-grained texture.

\subsubsection{Main Plutons}

\subsubsection{Ma'anshan Composite Pluton}

\section{Geological Features}

Ma'anshan composite pluton is located in the northwest of the survey area, with $83.86 \mathrm{~km}^{2}$ area, and its main body spreads along the NE-strike, distributed at the intersection of northern Zhejiang and southern Anhui, and intruded into the northeastern part of the Hanggai-Fushi NE-strike anticlinorium between the NE-strike Maotan-Luocun Fault and the Tongkengcun-Qiguancun Fault. The northwestern part of the pluton (outside the survey area, in Anhui Province) is in intrusive contact with the Silurian strata, and the dipstrike of the contact surface is $300^{\circ}-330^{\circ} \angle 45^{\circ}-60^{\circ}$, the dip angle is up to $80^{\circ}$ at very few places, and locally it is in NE-strike fault contact with the strata; the southwestern part in its southeastern side borders on NE-strike Tongkengcun-Qiguancun Fault, and is in fault contact with the Cambiran-Ordovician strata, and the overall dipstrike of the fault surface is $150^{\circ} \angle 45^{\circ}$. Its northeastern part is in intrusive contact with the Silurian strata, dipping toward southeast in general (Fig. 3.1).

\section{Petrological Features}

The composite pluton is mainly composed of early (pegmatitic and megacrystic) monzonitic granite and late fine-grained syenogranite, and later was intruded by a series NE-strike granite (porphoritic) veins.

\section{(Pegmatitic and megacrystic) porphyritic monzonitic granite}

It is the main lithology of Ma'anshan composite pluton, pegmatitic or megacrystic porphyritic granitoid texture, massive structure, and both are in progressive transitional contact and there is no obvious borderline between the two in the area. Pegmatitic phenocrysts grain size is generally $>3 \mathrm{~cm}$ (Fig. 3.2a), up to $5 \mathrm{~cm}$, megacryst grain size is $1-$ $3 \mathrm{~cm}$ and both mainly contains plagioclase (5-10\%) and $\mathrm{K}$-feldspar (2-4\%); Matrix: grain size is generally 3-8 mm, mainly quartz (20-25\%), K-feldspar (20-25\%), plagioclase (20-25\%), biotite $(10-15 \%)$, and a handful of hornblende (1-2\%), and accessory minerals are mainly zircon and apatite, etc. Quartz is anhedral granular, some irregular quartz is inlaid in K-feldspar to form graphic texture; biotite crystallized in the gap of feldspar and quartz (Fig. 3.2g) is present as foliated aggregates (Fig. 3.2e); K-feldspar is mostly anhedral granular, plagioclase is plate, and it is visible that plagioclase wrapping early-crystallized K-feldspar formed growth zoning (Fig. 3.2f). Porphyritic monzonitic granite has developed many dark fine-grained dioritic enclaves (MMEs), in ellipse or irregular shapes, are $1-20 \mathrm{~cm}$ in length, with clear border (Fig. 3.2b) and enclaves at some places contain very few plagioclase phenocryst in the size of 3-5 mm. Regionally, the intrusive contact between porphyritic monzonitic granite and fine-grained syenogranite or pegmatitic granite veins is clear, and in the contact zone with pegmatitic granite lens, it is usually seen that biotite concentrates in flow line in the shape of strip (Fig. 3.2c), and locally the occurrence is $145^{\circ} \angle 25^{\circ}$, similar to the contact surface. Pegmatitic and megacrystic porphyritic monzonitic granite progressively become medium-fine-grained porphyritic monzonitic granite at the margin. 


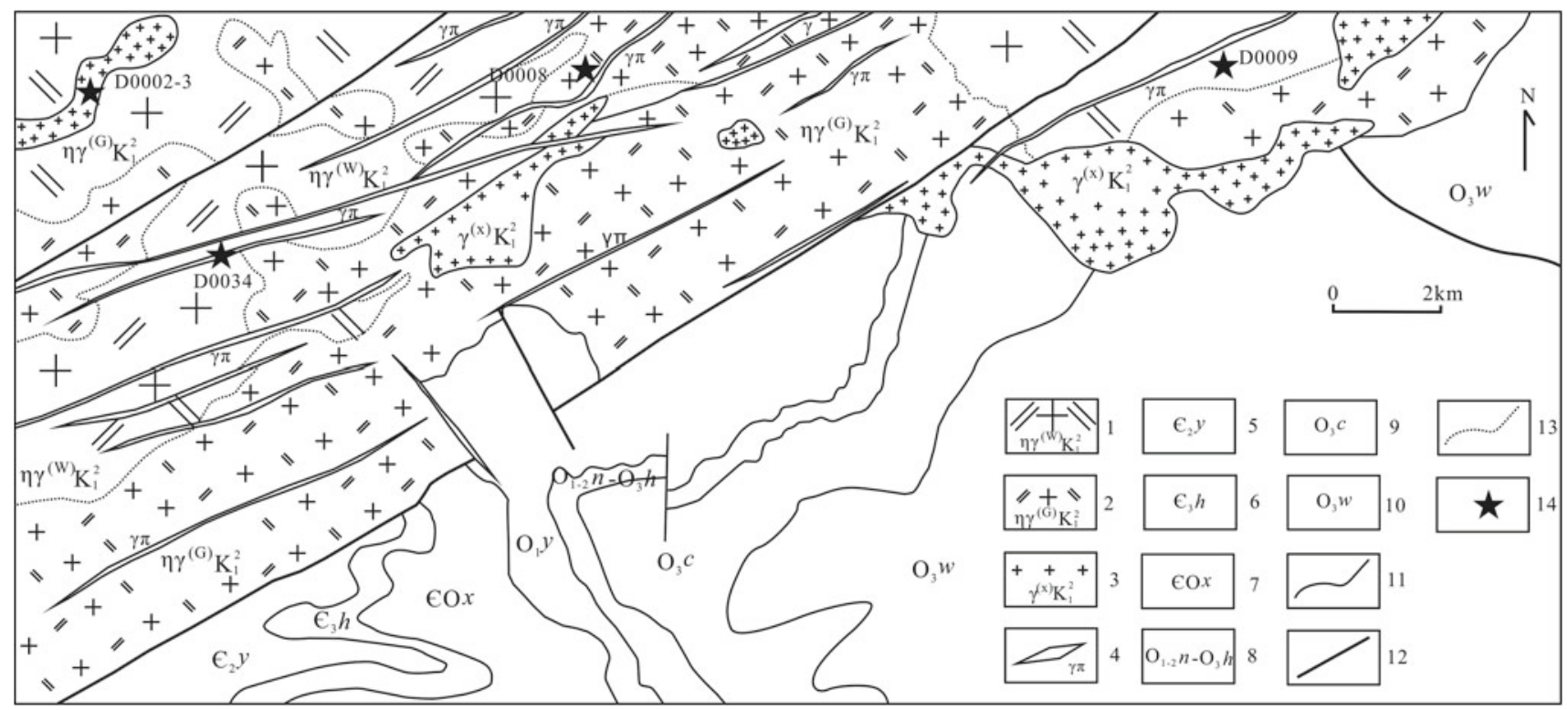

Fig. 3.1 Regional geological sketch map of Ma'anshan composite pluton. 1. Pegmatitic porphyritic monzonitic granite in second phase Early Cretaceous; 2 . Early Cretaceous Period-2 Phenocryst-porphyritic monzonitic granite in second phase, Early Cretaceous; 3. Early Cretaceous Period-2 fine-grained syenogranite in second phase, Early Cretaceous; 4. Granite porphyry vein; 5. Cambrian Yangliugang

\section{Fine-grained syenogranite}

It is mainly in the form of small apophysis, intruded into porphyritic monzonitic granite (Fig. 3.3) or near the contact zone between porphyritic monzonitic granite and wall rocks, irregular long strip, and its length and width vary between 100 and $1500 \mathrm{~m}$. Rocks are of fine-grained granitoid texture and massive structure; minerals mainly are quartz (30-35\%), K-feldspar (45-50\%), plagioclase (15-20\%), and a handful of dark-colored minerals such as biotite and hornblende, and accessory minerals are apatite and zircon; the grain size is generally $<2 \mathrm{~mm}$ (Fig. 3.2d); quartz is in anhedral granular, feldspar is lath-shaped, quartz and feldspar are distributed alternately in equigranular texture, and crystals such as hornblende and biotite are developed at the contact margin (Fig. 3.2i). In fine-grained syenogranite, layer joints is often seen, and flow line and planar flow structure are seen sometimes; especially, fine-grained syenogranite in Guocun has developed parallel joints which are basically consistent with the platy joints in early pegmatitic porphyritic monzonitic granite, and weakly oblique joints of which structure are closely related to mineralization of $\mathrm{W}$-Be-quartz veins.

\section{Wall-rock Alteration}

Regionally, pegmatitic and megacrystic porphyritic monzonitic granite is strongly weathered and has developed alteration. Plagioclase and K-feldspar frequently show
Formation; 6. Cambrian Huayansi Formation; 7. Cambrian-Ordovician Xiyangshan Formation; 8. Ordovician Ningguo Formation-Huangnigang Formation; 9. Ordovician Changwu Formation; 10. Ordovician Wenchang Formation; 11. Geological boundary; 12. Fault; 13. Lithofacies boundary; 14. Sampling location

albitazation, chloritization, and kaolinization alterations, etc., along cracks. The fracture zone inside the pluton has developed silicification alteration or filled with quartz vein. Greisenization is seen in margin of the pluton.

Fine-grained syenogranite is weakly weathered, a handful of feldspar probably developed epidotization along cracks, and the contact zone developed joints structure and silicified quartz vein. The Silurian sandstone strata in the southeast side of the pluton mainly have developed hornfelsic alteration. Since the contact surface's dip angle is gentle, the hornfelsic zone is generally $1-3 \mathrm{~km}$ wide, the inner zone is about $1.5 \mathrm{~km}$ wide and mainly contains dark purple gray hornfels, and the outer zone is about $1.2 \mathrm{~km}$ wide and mainly contains dark purple gray and hornfelsic siltstone. The Ordovician calcareous siltstone around the Yonghe Forest Farm in its southeast which is interbedded with micro-crystal limestone, and the strata there have developed silicification, poorly skarnization, and marbleization.

\section{Geochemical Features}

Lithologies in Ma'anshan composite pluton are high in $\mathrm{SiO}_{2}$ content (67.09-76.74\%), enrichment in alkali (Alk $=\mathrm{K}_{2} \mathrm{O}+$ $\mathrm{Na}_{2} \mathrm{O}, 8.02-8.74 \%$ ), high in the $\mathrm{K}_{2} \mathrm{O} / \mathrm{Na}_{2} \mathrm{O}$ ratio (1.24-1.78\%); low $\mathrm{MgO}(0.18-1.26 \%)$, low $\mathrm{P}_{2} \mathrm{O}_{5}(0.01-0.2 \%)$, and low $\mathrm{TiO}_{2}$ $(0.06-0.56 \%)$. Both monzonitic granite and syenogranite have higher differentiation index (DI) (78.62-89.28, 93.73-95.01), similar to the highly differentiated I-type granite (82-94) in 
(a)

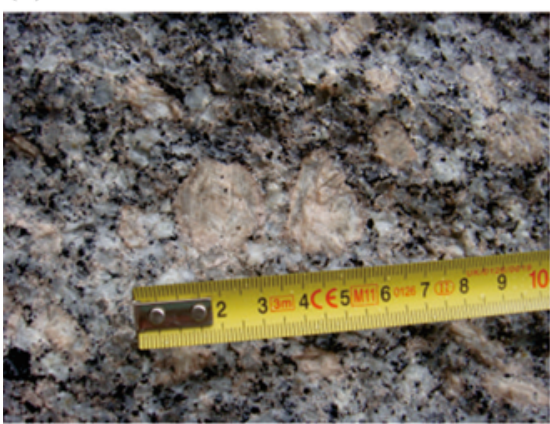

(d)

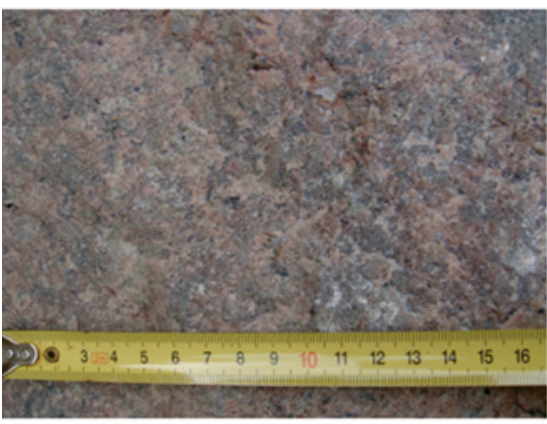

(g)

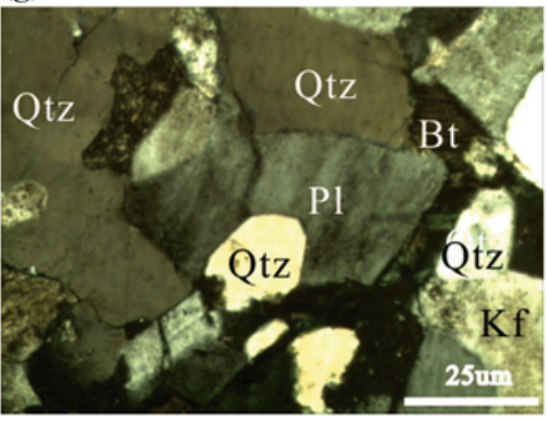

(b)

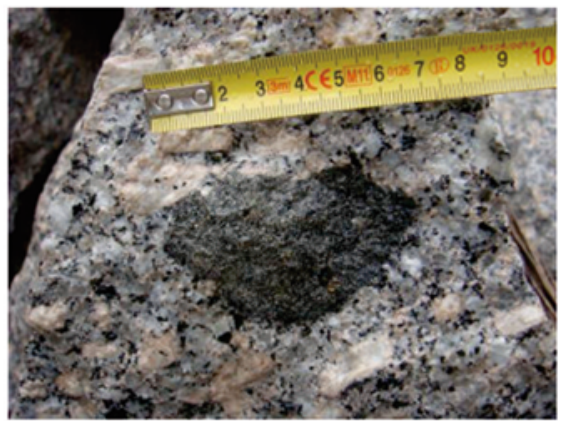

(e)

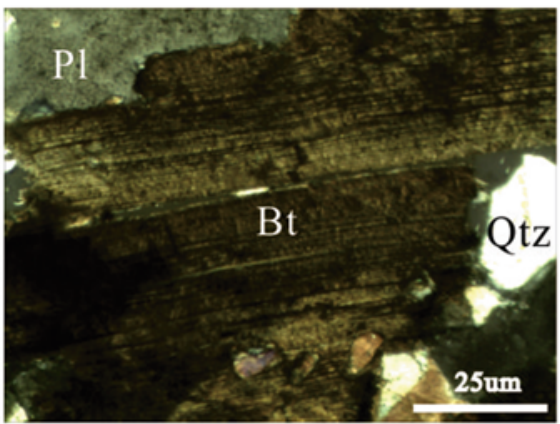

(h)

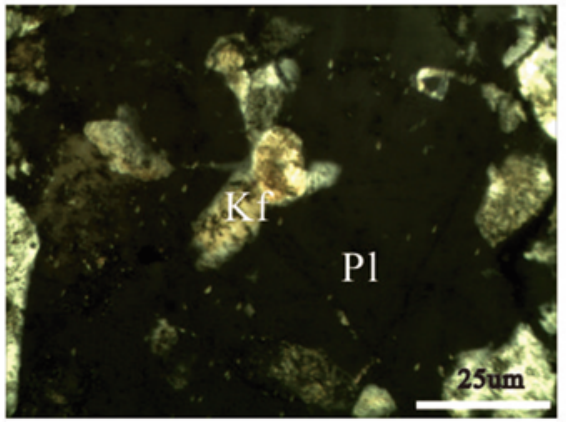

(c)

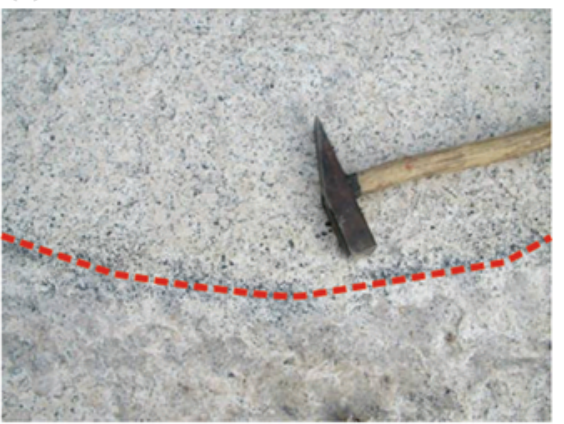

(f)

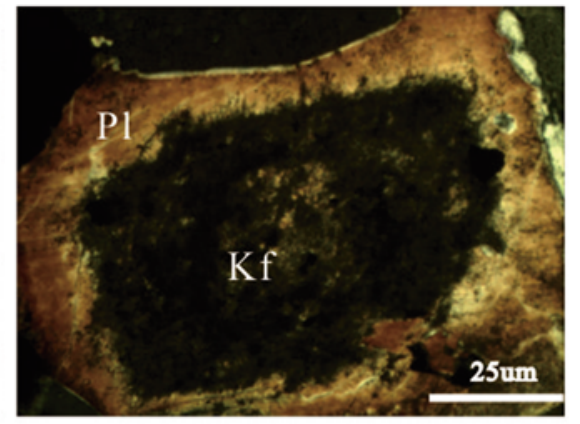

(i)

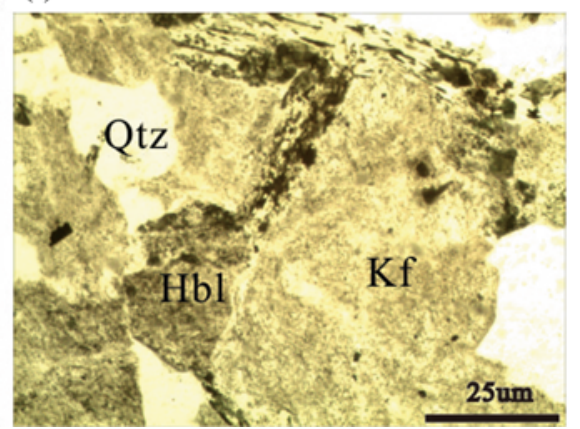

Fig. 3.2 Field pictures and petrographical microscopic pictures of Ma'anshan composite pluton. a K-feldspar phenocryst in pegmatitic porphyritic monzonitic granite; b dioritic enclaves developed in pegmatitic porphyritic monzonitic granite; c biotite concentrates in strips at the margin of phenocryst-porphyritic monzonitic granite and fine-grained syenogranite; d fine-grained syenogranite; e biotite $(\mathrm{Bt})$, plagioclase $(\mathrm{Pl})$ and quartz $(\mathrm{Qtz})$ in phenocryst-porphyritic monzonitic granite; f plagioclase $(\mathrm{Pl})$ containing $\mathrm{K}$-feldspar $(\mathrm{Kf})$ core grown in phenocryst-porphyritic monzonitic granite; $\mathbf{g}$ biotite $(\mathrm{Bt})$ gets crystallized at the contact edge of quartz $(\mathrm{Qtz})$, plagioclase $(\mathrm{Pl})$ and $\mathrm{K}$-feldspar (Kf) in pegmatitic porphyritic monzonitic granite; h plagioclase (Pl) wrapping K-feldspar $(\mathrm{Hbl})$ in pegmatitic porphyritic monzonitic granite; i quartz (Qtz), K-feldspar (Kf), and hornblende (Hbl) in fine-grained syenogranite
Fig. 3.3 Features of internal-facies zones of megacrystic porphyritic monzonitic granite in Ma'anshao composite pluton

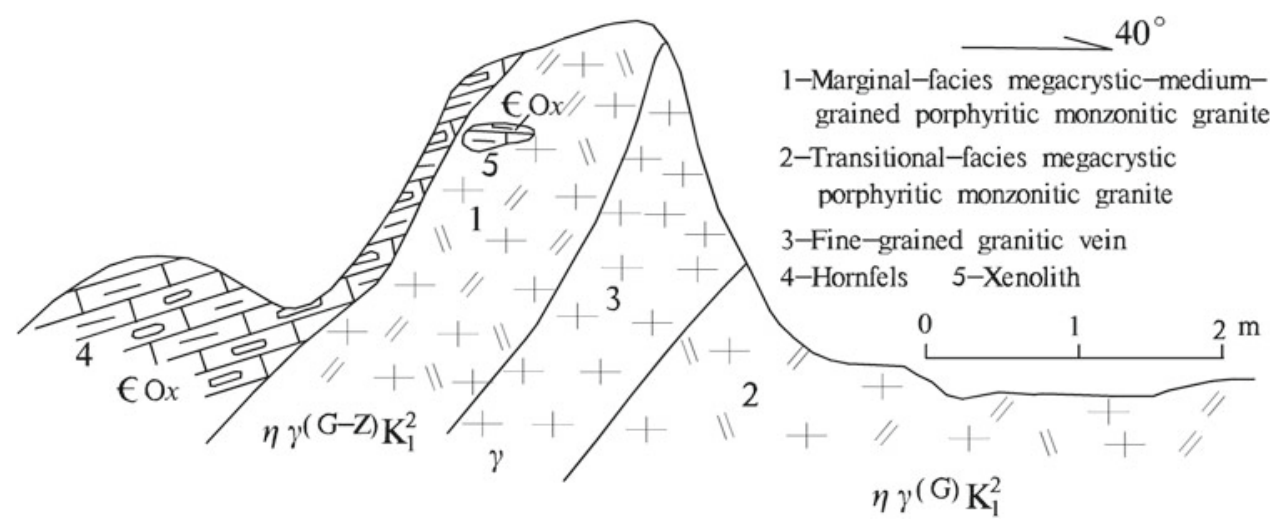



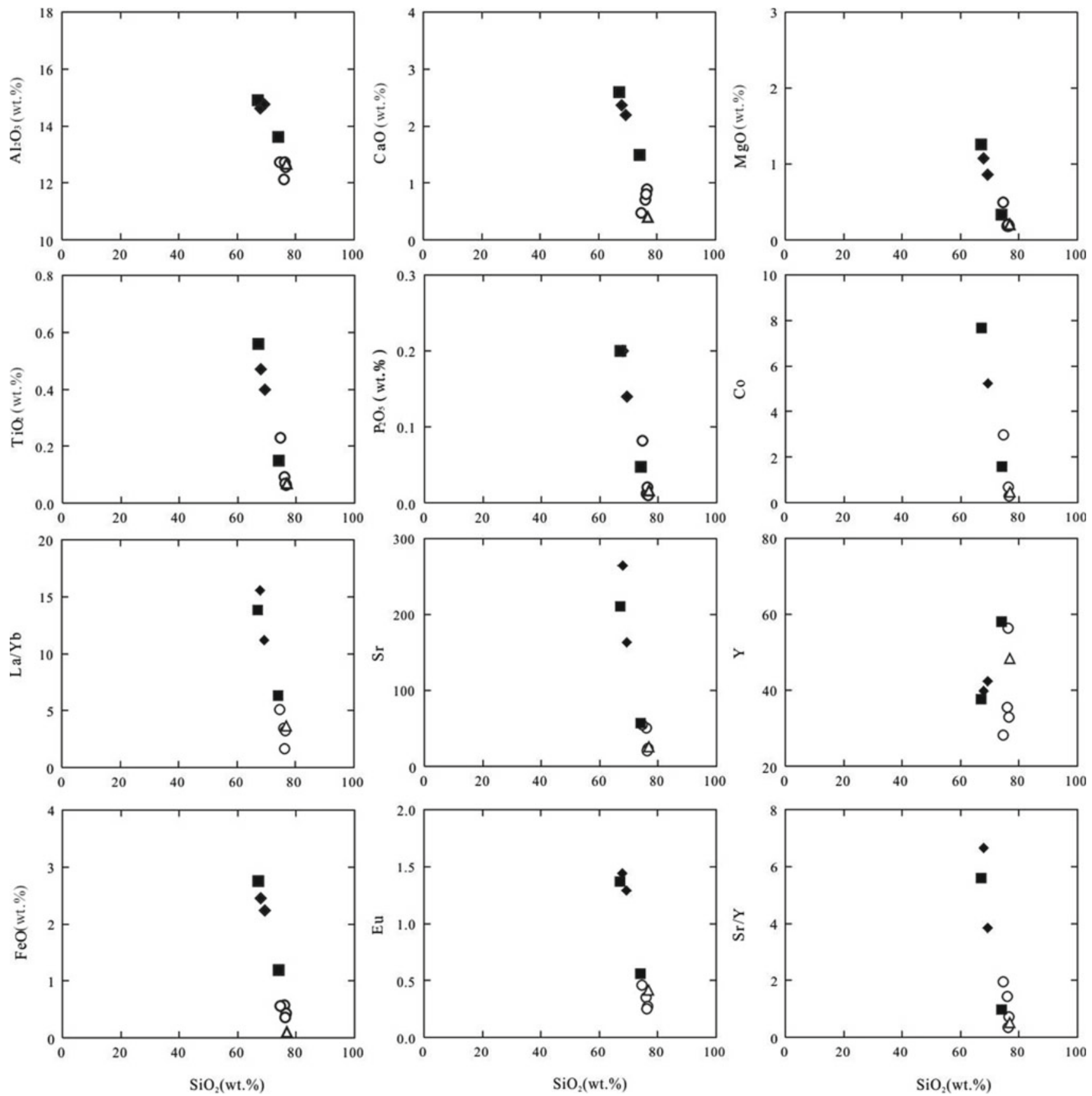

Fig. 3.4 Harker diagram of $\mathrm{SiO}_{2}$ in $\mathrm{Ma}^{\prime}$ anshan composite pluton (its legends are the same as those in Fig. 3.5)

Fogang, South China. In some samples of CIPW standard minerals, a handful of corundum $(0.16-0.47 \%$, a few $1.63 \%)$ and diopside (0.02-0.58\%, a few $1.37 \%)$.

From pegmatitic and megacrystic porphyritic monzonitic granite to fine-grained syenogranite, the content of $\mathrm{SiO}_{2}$ and $\mathrm{K}_{2} \mathrm{O}$, the $\mathrm{K}_{2} \mathrm{O} / \mathrm{Na}_{2} \mathrm{O}$ ratio, and DI increase gradually, the contents of $\mathrm{TiO}_{2}, \mathrm{Al}_{2} \mathrm{O}_{3}, \mathrm{TFeO}, \mathrm{MgO}, \mathrm{CaO}$, and $\mathrm{P}_{2} \mathrm{O}_{5}$ decrease gradually, and the contents of $\mathrm{MnO}$ and $\mathrm{Na}_{2} \mathrm{O}$ vary small. In Harker diagram (Fig. 3.4), $\mathrm{Al}_{2} \mathrm{O}_{3}, \mathrm{CaO}, \mathrm{MgO}$, $\mathrm{FeO}, \mathrm{TiO}_{2}, \mathrm{P}_{2} \mathrm{O}_{5}$, and $\mathrm{Fe}_{2} \mathrm{O}_{3}$ have a negative correlation with
$\mathrm{SiO}_{2}, \mathrm{~K}_{2} \mathrm{O}$ is in weakly positive correlation with $\mathrm{SiO}_{2}$, and $\mathrm{Na}_{2} \mathrm{O}$ has no clear relationship with $\mathrm{SiO}_{2}$. All these results suggested that with differentiation evolution becoming more sufficient, lithologies evolved toward acidity and alkalinity did not change greatly. $\mathrm{A} / \mathrm{CNK}$ is $0.95-1.14$, increasing gradually, featuring evolution from quasi-aluminous to weakly peraluminous (Fig. 3.5). Rittmann Index $(\sigma)$ is 1.92 2.77, featuring evolution from the shoshonite series to the high $\mathrm{K}-\mathrm{Ca}$ alkaline series. $\mathrm{TFeO} /(\mathrm{TFeO}+\mathrm{MgO})$ ratio is 0.75-0.81 (0.77) and 0.77-0.89 (0.81), respectively. 

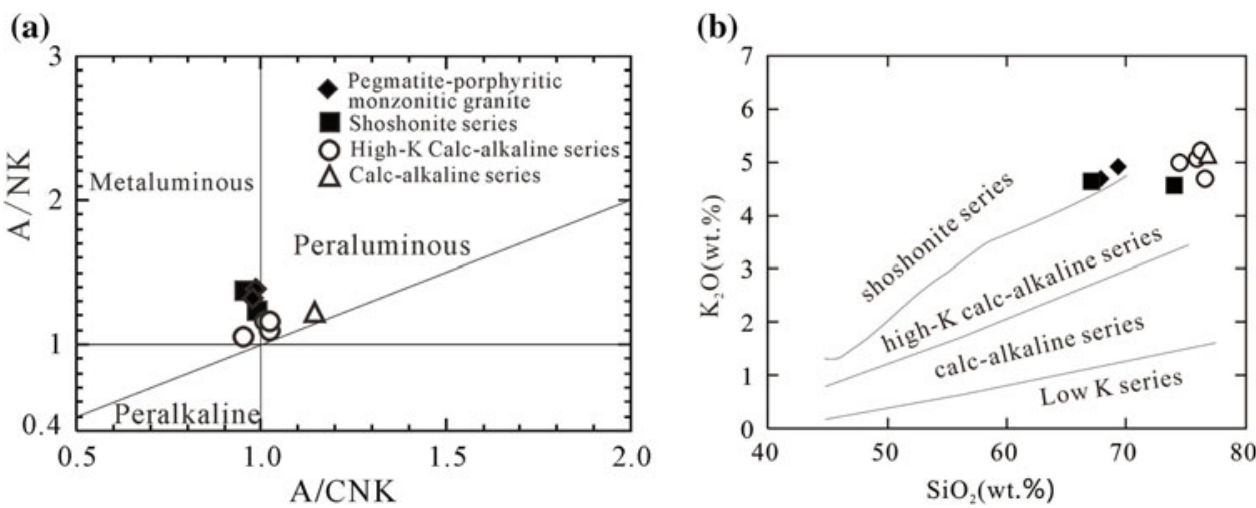

Fig. 3.5 A/CNK-A/NK diagram (a) and $\mathrm{SiO}_{2}-\mathrm{K}_{2} \mathrm{O}$ diagram (b) for Ma'anshan composite pluton

(a)

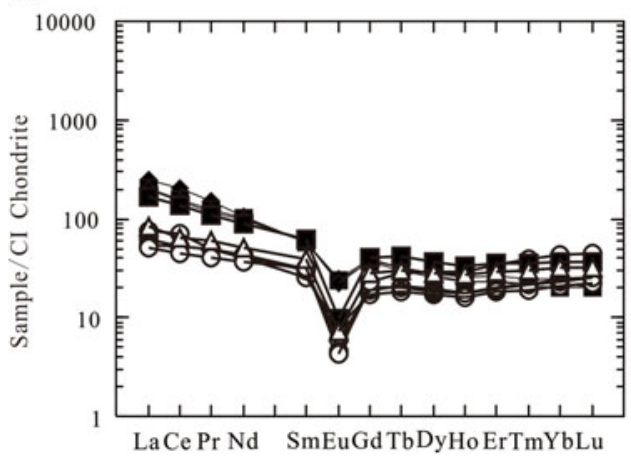

(b)

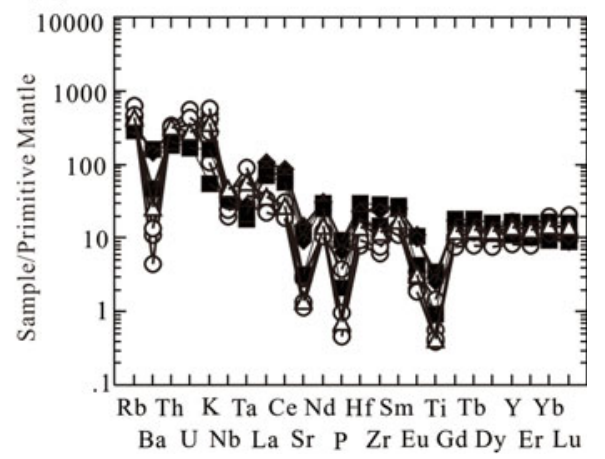

Fig. 3.6 Chondrite-normalized REE distribution mode (a) and primitive mantle-normalized trace element spider diagram (b) for Ma'anshan composite pluton (the normalized values of chondrite and primitive mantle come from Sun and McDonough 1989)

$\mathrm{TFeO} / \mathrm{MgO}$ ratio is 3.04-4.37 and 3.36-7.77, respectively, and mean value is close to the I-type granite (2.27) but very different from the A-type granite (13.4).

Pegmatitic and megacrystic porphyritic monzonitic granite is high in content of $\sum \operatorname{REE}\left(218.89 \times 10^{-6}-283.63 \times 10^{-6}\right)$, and the chondrite-normalized REE patterns show a feature of weakly dipping toward right, light rare-earth elements (LREE), and heavy rare-earth elements (HREE) differentiate pretty obvious, $\mathrm{La}_{\mathrm{N}} / \mathrm{Yb}_{\mathrm{N}}$ is $4.53-11.18$ and $\delta \mathrm{Eu}$ is $0.19-0.52, \mathrm{Eu}$ showing stronger negative anomaly; rocks are enriched in $\mathrm{K}$, Th, U, and Rb, weakly depleted in LILE such as Ba; weakly depleted in high field-strength elements (HFSE) such as $\mathrm{Sr}, \mathrm{P}$, $\mathrm{Nb}$, Ta, and Ti. Fine-grained syenogranite is low in the content of $\sum \operatorname{REE}\left(94.28 \times 10^{-6}-122.78 \times 10^{-6}\right)$. The chondritenormalized REE patterns show a feature of "V" shape, and LREE and HREE differentiate not so obviously. $\mathrm{La}_{\mathrm{N}} / \mathrm{Yb} \mathrm{b}_{\mathrm{N}}$ is $1.17-3.64$ and $\delta$ Eu is $0.15-0.38$, Eu showing a strong anomaly; similarly, it is enriched in large-ion lithophile elements (LILE) such as $\mathrm{K}$, Th, $\mathrm{U}$, and $\mathrm{Rb}$, but strongly depleted in elements such as $\mathrm{Ba}$ and $\mathrm{Sr}$; strongly depleted in HFSE such as $\mathrm{P}, \mathrm{Nb}$, and $\mathrm{Ti}$ (Fig. 3.6).

Pegmatitic porphyritic monzonitic granite $\left({ }^{86} \mathrm{Sr} /{ }^{87} \mathrm{Sr}\right)_{\mathrm{i}}$ is $0.70825, \varepsilon \mathrm{Nd}(t)$ is -6.77 and the two-stage model ages $\left(T_{\mathrm{DM} 2}\right)$ is $1.47 \mathrm{Ga}$; fine-grained syenogranite $\left({ }^{86} \mathrm{Sr} /{ }^{87} \mathrm{Sr}\right)_{\mathrm{i}}$ is
$0.69215, \varepsilon \mathrm{Nd}(t)$ is -6.59 , and $T_{\mathrm{DM} 2}$ is $1.46 \mathrm{Ga}$; both have similar features, indicating their same magma evolution.

\section{Isotope geochronology}

In porphyritic monzonitic granite, zircon mostly is irregular long strip, 100-200 $\mu \mathrm{m}$ in length, the length-width ratio is about 2:1, and zircon has developed oscillatory zoning. In fine-grained syenogranite, zircon mostly is irregular short strips and granular, $50-100 \mu \mathrm{m}$ in length, or occasional 100 $200 \mu \mathrm{m}$, the length-width ratio is about 2:1-1:1 and also zircon has developed oscillatory zoning (Fig. 3.7). In pegmatitic porphyritic monzonitic granite, megacrystic porphyritic monzonitic granite and fine-grained syenogranite, the $U$ content in zircon is $(242-2041) \times 10^{-6},(100-2886) \times 10^{-6}$, and $(114$ $1863) \times 10^{-6}$, respectively, and the Th content is (97$349) \times 10^{-6}, \quad(38-499) \times 10^{-6}$, and $(52-497) \times 10^{-6}$, respectively, and the $\mathrm{Th} / \mathrm{U}$ ratio is $0.11-0.41,0.16-1.05$, and 0.22-0.97, respectively, a typical feature of magmatic original zircon (Hoskin and Schaltegger 2003). Sample locations mostly are projected on or near the concordant curve, ${ }^{206} \mathrm{~Pb} /{ }^{238} \mathrm{U}$ weighted mean age is $132.2 \pm 1.6 \mathrm{Ma}$ (MSWD = 1.9), $127.7 \pm 1.2 \mathrm{Ma}(\mathrm{MSWD}=1.3)$, and $128.3 \pm 1.1 \mathrm{Ma}$ $(\mathrm{MSWD}=1.7)$, respectively (Fig. 3.8), representing the 


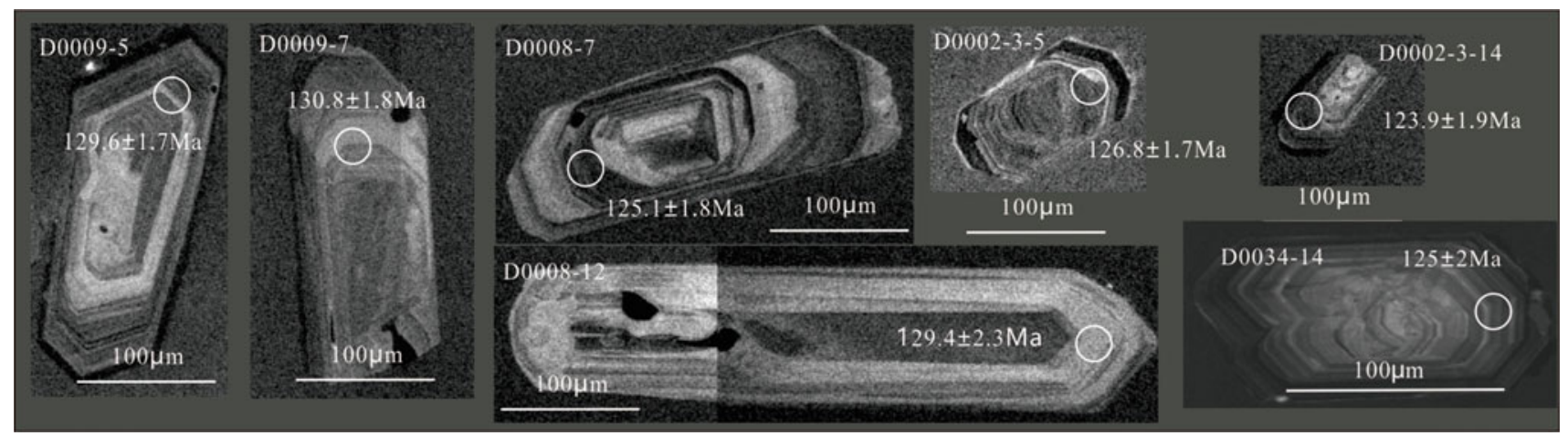

Fig. 3.7 Main zircon cathodoluminescence (CL) imaging and dating spots diagram of samples from Ma'anshan composite pluton
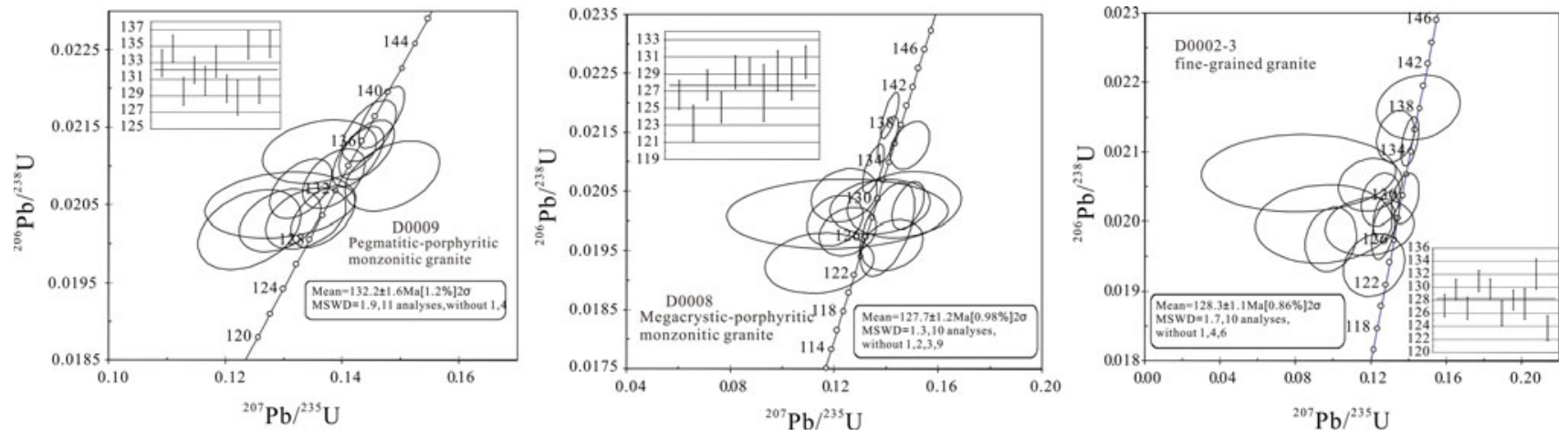

Fig. 3.8 Zircon $\mathrm{U}-\mathrm{Pb}$ concordant diagrams for Ma'anshan composite pluton

crystallization age of Ma'anshan pluton. Of these, ${ }^{206} \mathrm{~Pb} / 238 \mathrm{U}$ ages at the sample locations D0009-14 and D0002-3-8 are $414 \mathrm{Ma}$ and $310.5 \mathrm{Ma}$, showing older ages and possibly representing inherited zircon.

Based on the contact relationships, geochronological and geochemical features, Ma'anshan composite pluton experienced two stages of magmatism, the early stage is pegmatitic and megacrystic porphyritic monzonitic granite $(132.2 \pm 1.6 \mathrm{Ma}-127.7 \pm 1.2 \mathrm{Ma})$ and the later stage is fine-grained syenogranite $(128.3 \pm 1.1 \mathrm{Ma})$.

\subsubsection{Tangshe Composite Pluton}

\section{Geological Features}

Tangshe composite pluton is situated in the midwest of the survey area, with outcrop area of about $18.9 \mathrm{~km}^{2}$, NE-strike, distributed in Tangsheling which is the intersection of Zhejiang and Anhui Province. The pluton, in the shape of stock, intruded into the core of Wangjia-Tangshecun anticline (Fig. 3.9), of which the distribution direction is consistent with the anticline axis. It is in intrusive contact with wall rocks on both sides, and the dip angle of contact surface is generally steep with a range of $50^{\circ}-80^{\circ}$, all dipping outwards; wall rocks are mainly the Neoproterozoic Nanhuaian to Cambrian strata. Many secondary faults in NE, NEE, and NW-strike have developed inside and surrounded the pluton.

\section{Petrological Features}

The composite pluton is mainly composed of early medium-grained monzonitic granite and late medium-coarsegrained (coarse-medium-grained) syenogranite, and fine-medium-grained syenogranite.

\section{Medium-grained monzonitic granite}

It is distributed in the southern part of the composite pluton, NEE strike, $10-12 \mathrm{~km}$ in length and $1-2 \mathrm{~km}$ in width, and its north side is in surging intrusive contact with medium-coarse-grained syenogranite. Rocks are offwhite, medium-grained texture, and massive structure, and mainly contain quartz (20\%), K-Na-feldspar (30\%), plagioclase (35\%), biotite (5-10\%), hornblende (5\%), a handful of pyrite and magnetite, etc., and zircon and apatite occasionally seen; the grain size is generally $2-3 \mathrm{~mm}$, or a few $0.5-2 \mathrm{~mm}$; quartz is anhedral granular, not evenly distributed; plagioclase is platy, and mainly andesine-oligoclase (Fig. 3.10a, d). 


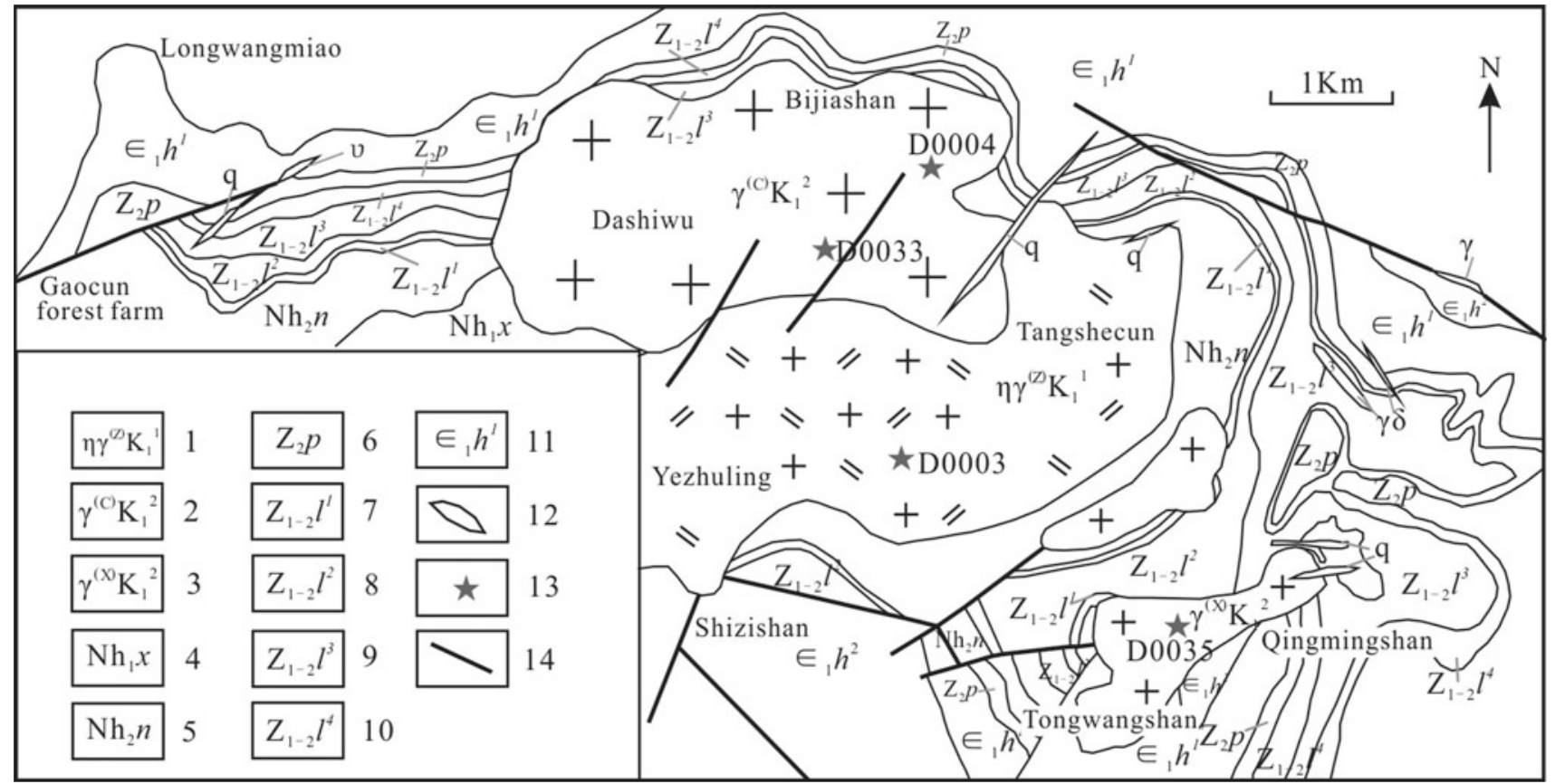

Fig. 3.9 Regional geological sketch map of Tangshe composite the second member of Lantian Formation; 9. the third member of pluton. 1. medium-grained monzonitic granite; 2. Lantian Formation; 10. the fourth member of Lantian Formation; 11. medium-coarse-grained syenogranite; 3. medium-fine-grained the first member of Hetong Formation; 12. veins; 13. sampling location; syenogranite; 4. the Xiuning Formation; 5. the Nantuo Formation; 6. 14. faults the Piyuancun Formation; 7. the first member of Lantian Formation; 8.
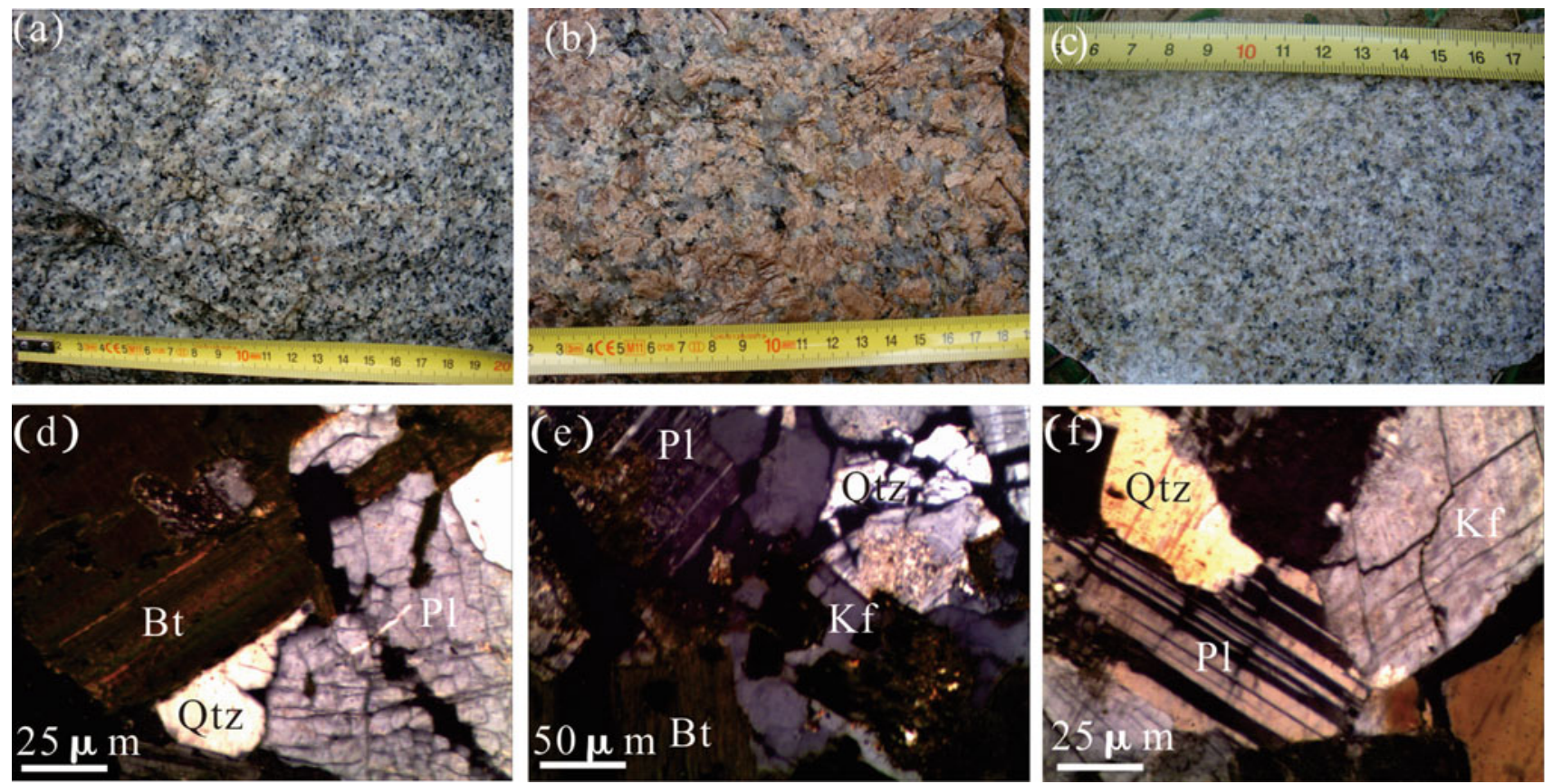

Fig. 3.10 Outcrop and microscopic petrographical pictures of Tangshe composite pluton. a medium-grained monzonitic granite; b medium-coarse-grained syenogranite; c fine-grained syenogranite; d plagioclase $(\mathrm{Pl})$, biotite $(\mathrm{Bt})$, and quartz $(\mathrm{Qtz})$ in medium-grained monzonitic granite; e K-feldspar (Kf), plagioclase ( $\mathrm{Pl})$ showing polysynthetic twin, quartz $(\mathrm{Qtz})$, and biotite $(\mathrm{Bt})$ in coarse-grained syenogranite; $\mathbf{f}$ plagioclase $(\mathrm{Pl})$ showing polysynthetic twin, K-feldspar $(\mathrm{Kf})$, and quartz $(\mathrm{Qtz})$ in fine-grained syenogranite 


\section{Medium-coarse-grained syenogranite}

The rocks are distributed in the northern part of the composite pluton, EW strike, short strip, $3.5 \mathrm{~km}$ in length, and $1.5 \mathrm{~km}$ in width, it is transitioned in local parts of the contact zone with early stage medium-grained monzonitic granite to become coarse-medium-grained (porphyritic) syenogranite, and the margins of its east and west margins are progressively transitioned to become medium-fine-grained syenogranite. Rocks are pink, medium-coarse-grained (porphyritic) granitic texture and massive structure, and mainly contain K-feldspar (40\%), plagioclase (15\%), quartz (30\%), biotite $(5-10 \%)$, hornblende $(3 \%)$, a handful of metallic minerals, and zircon occasionally seen; mineral's grain size is bigger, K-feldspar's grain size up to 1-2 cm, a few's grain size $>3 \mathrm{~cm}$, K-feldspar mostly in the shape of square, highly idiomorphic; quartz is in idiomorphic texture, inlaid in K-feldspar, and forms graphic texture (Fig. 3.10b, e).

\section{Fine-medium-grained monzonitic granite}

The rocks are distributed in the southeastern of the composite pluton, NE-strike, about $2 \mathrm{~km}$ in length, and $0.5-1 \mathrm{~km}$ in width. Rocks are pink, medium-grained granitic texture and massive structure, and mainly contain quartz (30\%), alkaline feldspar (45\%), plagioclase $(20 \%)$, biotite $(5 \%)$, a handful of metallic minerals, zircon, and apatite occasionally seen; the mineral grain size is generally $2-6 \mathrm{~mm}$, and a few up to $6-$ $7 \mathrm{~mm}$. Quartz is anhedral granular, with more content, not evenly distributed; feldspar is platy, mainly alkaline feldspar, less plagioclase; biotite is schistose, not evenly distributed, but locally concentrated (Fig. 3.10c, f).

\section{Wall-rock Alteration}

Tangshe composite pluton is weathered strongly, showing albitazation and greisenization. The interior pluton has developed secondary fractures, its both sides developed silicification and sericitization; its margins developed joints structure, and tungsten-bearing quartz vein in the northern margin of medium-grained monzonitic granite is mainly related to the NNW-strike joints. Alterations in wall-rock strata are mainly skarnization and hornfelsic, locally silicification and marbleization; the Nanhuaian siltstone and sandy conglomerate in the western and eastern sides of the composite pluton developed strong hornfelsic alteration, with 1-2 km in alteration width; the Sinian Lantian Formation strata in northern side developed strong skarnization and marbleization, the skarn zone is 5-100 m generally, minerals assemblage included garnet, pyroxene, epidote, minor idocrase, etc., layer-like $\mathrm{Pb}-\mathrm{Zn}$ ore (mineralization) bodies can be seen, scheelite mineralization can be seen locally, the borderlines of the contact surface in metallogenic areas are often irregular, accompanied with tongue-shape protrusion, and the dip angle has direct impact on mineralization alteration zones with respect to width and strength.

\section{Geochemical Features}

Tangshe composite pluton is high in $\mathrm{SiO}_{2}$ content (67.83$75.88 \%)$, enriched in alkali $\left(\mathrm{Alk}=\mathrm{K}_{2} \mathrm{O}+\mathrm{Na}_{2} \mathrm{O}, 7.18\right.$ $8.84 \%$ ), high in $\mathrm{K}_{2} \mathrm{O} / \mathrm{Na}_{2} \mathrm{O}$ ratio (0.95-1.63\%) (Fig. 3.11); low in $\mathrm{MgO}(0.06-0.98 \%)$, low in $\mathrm{P}_{2} \mathrm{O}_{5}(0.01-0.28 \%)$, and low in $\mathrm{TiO}_{2}(0.09-0.52 \%)$. The DI indexes of medium-grained monzonitic granite, medium-coarse-grained and coarse-mediumgrained syenogranite and medium-fine-grained syenogranite are higher (76.54-77.94, 90.23-92.95, 92.53), of which the latter two are similar to the highly differentiated I-type granite (82-94) in Fogang in South China.

From medium-grained monzonitic granite to medium-coarse-grained and coarse-medium-grained syenogranite to medium-fine-grained syenogranite, the content of $\mathrm{SiO}_{2}$ and $\mathrm{K}_{2} \mathrm{O}$, the $\mathrm{K}_{2} \mathrm{O} / \mathrm{Na}_{2} \mathrm{O}$ ratio, and DI increase gradually, the contents of $\mathrm{TiO}_{2}, \mathrm{Al}_{2} \mathrm{O}_{3}, \mathrm{TFeO}, \mathrm{MgO}, \mathrm{CaO}$, and $\mathrm{P}_{2} \mathrm{O}_{5}$ decrease gradually, and the contents of $\mathrm{MnO}$ and $\mathrm{Na}_{2} \mathrm{O}$ vary fewly. The contents of $\mathrm{Al}_{2} \mathrm{O}_{3}, \mathrm{CaO}, \mathrm{MgO}, \mathrm{FeO}, \mathrm{TiO}_{2}, \mathrm{P}_{2} \mathrm{O}_{5}$, and $\mathrm{Fe}_{2} \mathrm{O}_{3}$ have a negative correlation with $\mathrm{SiO}_{2}, \mathrm{~K}_{2} \mathrm{O}$ is in weakly positive correlation with $\mathrm{SiO}_{2}$, and $\mathrm{Na}_{2} \mathrm{O}$ has no clear relationship with $\mathrm{SiO}_{2}$. All these features suggest that with differentiation evolution becoming more sufficient, lithologies evolve toward acidity and their alkalinity does not change greatly. $\mathrm{A} / \mathrm{CNK}$ is 0.93 1.10, increasing gradually, featuring evolution from quasi-aluminous to weakly peraluminous (Fig. 3.12). Rittmann Index $(\sigma)$ is $1.88-2.47$, consistent with high $\mathrm{K}-\mathrm{Ca}$ alkaline

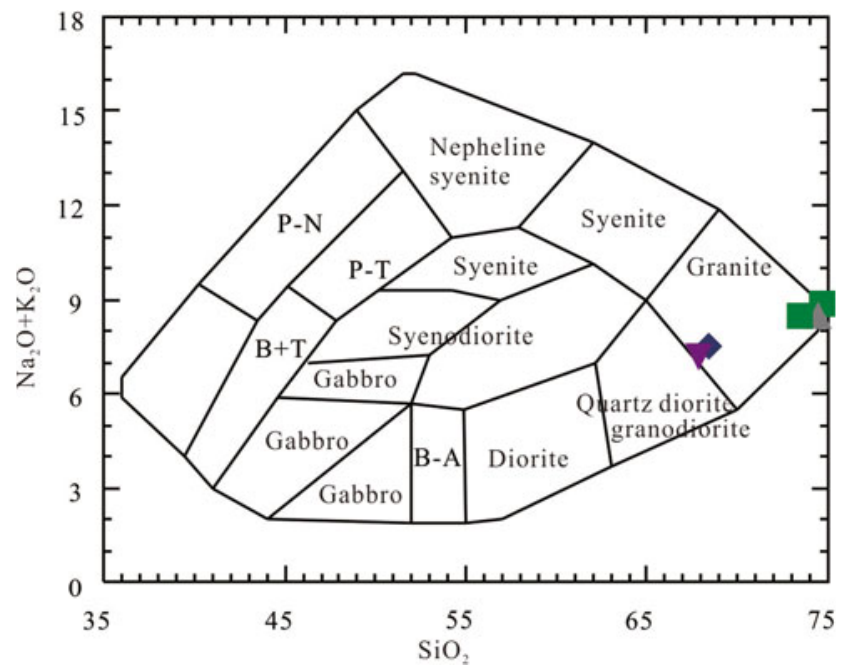

Fig. 3.11 $\mathrm{SiO}_{2}-\mathrm{Na}_{2} \mathrm{O}+\mathrm{K}_{2} \mathrm{O}$ diagram for Tangshe composite pluton (its legends are the same as those in Fig. 3.12) 
Fig. $3.12 \mathrm{~A} / \mathrm{CNK}-\mathrm{A} / \mathrm{NK}$ diagram (a) and $\mathrm{SiO}_{2}-\mathrm{K}_{2} \mathrm{O}$ diagram (b) for Tangshe composite pluton (a)

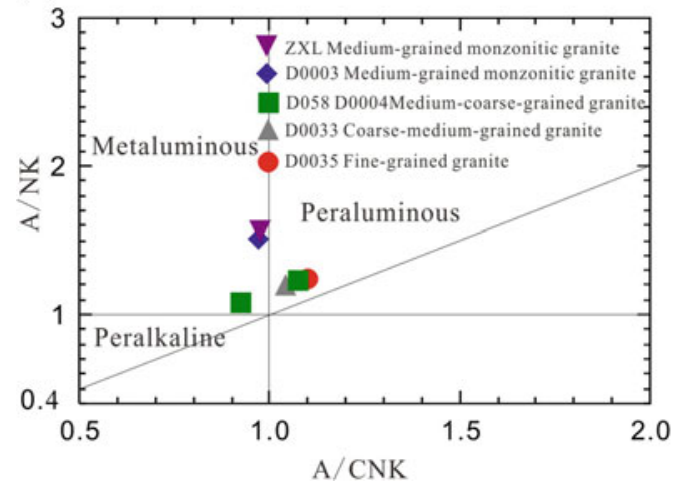

(b)

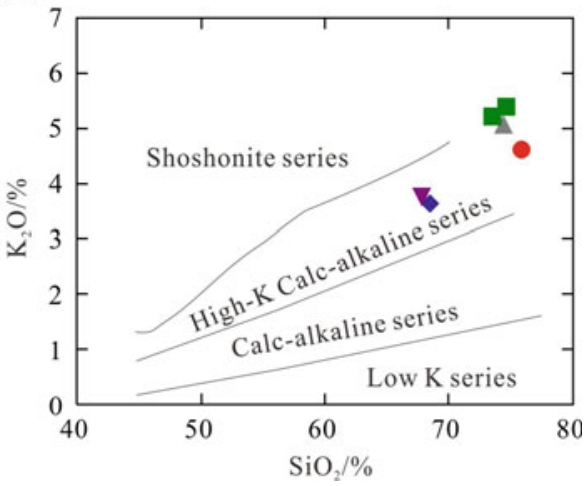

series. Their $\mathrm{TFeO} /(\mathrm{TFeO}+\mathrm{MgO})$ ratio is $0.77-0.79$ (0.78 in average), $0.81-0.86$ ( 0.84 in average), and 0.96 , respectively; their $\mathrm{TFeO} / \mathrm{MgO}$ ratio is $3.42-3.70$ (3.56 in average), 4.18-6.00 (5.08 in average), and 22.03, respectively.

Medium-grained monzonitic granite is low in content of $\sum \mathrm{REE} \quad\left(136.16 \times 10^{-6}-190.57 \times 10^{-6}\right), \quad$ and the chondrite-normalized REE patterns (Fig. 3.13) show a feature of weakly dipping toward right, LREE and HREE differentiate pretty obvious, $\mathrm{La}_{\mathrm{N}} / \mathrm{Yb}_{\mathrm{N}}$ is $17.25-19.14$ and $\delta \mathrm{Eu}$ is $0.64-0.72$, Eu showing weakly negative anomaly. Rocks are enriched in $\mathrm{K}$, Th, $\mathrm{U}$, and $\mathrm{Rb}$, weakly depleted in LILE such as Ba and $\mathrm{Sr}$; weakly depleted in HFSE such as $\mathrm{P}, \mathrm{Nb}, \mathrm{Ta}$, and Ti.

Medium-coarse-grained and coarse-medium-grained monzonitic granite is high in content of $\sum$ REE $\left(179.39 \times 10^{-6}-229.56 \times 10^{-6}\right)$, and the chondritenormalized REE patterns (Fig. 3.13) show a feature of weakly dipping toward right, LREE and HREE differentiate pretty obvious, $\mathrm{La}_{\mathrm{N}} / \mathrm{Yb}_{\mathrm{N}}$ is $5.92-16.45$ and $\delta \mathrm{Eu}$ is $0.22-$ 0.32 , Eu showing strong negative anomaly. Similarly, rocks are enriched in $\mathrm{K}$, Th, $\mathrm{U}$, and $\mathrm{Rb}$, weakly depleted in LILE such as $\mathrm{Ba}$ and $\mathrm{Sr}$; weakly depleted in HFSE such as $\mathrm{P}, \mathrm{Nb}$, $\mathrm{Ta}$, and Ti. $\left({ }^{86} \mathrm{Sr} /{ }^{87} \mathrm{Sr}\right)_{\mathrm{i}}$ value is $0.703,60, \varepsilon \mathrm{Nd}(\underline{t})$ value is -5.11 and $T_{\mathrm{DM} 2}$ is $1.34 \mathrm{Ga}$.

(a)

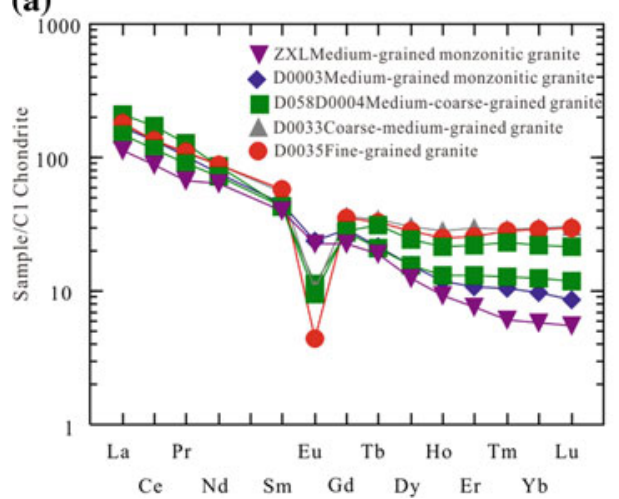

Fine-grained syenogranite is high in content of $\sum \mathrm{REE}$ $\left(214.70 \times 10^{-6}\right)$, and the chondrite-normalized REE patterns (Fig. 3.13) show a feature of "V" shape, light, and heavy rare earth differentiates unobviously, $\mathrm{La}_{\mathrm{N}} / \mathrm{Yb}_{\mathrm{N}}$ is 6.24 and $\delta \mathrm{Eu}$ is 0.10 , Eu showing strongly negative anomaly. Similarly, the rocks are also enriched in LILE such as $\mathrm{K}, \mathrm{Th}, \mathrm{U}$, and $\mathrm{Rb}$, strongly depleted in LILE such as Ba and Sr; in terms of HFSE, strongly depleted in $\mathrm{P}$ and $\mathrm{Ti}$, weakly depleted in $\mathrm{Nb}$ and $\mathrm{Ta}$.

\section{Isotope geochronology}

In medium-grained monzonitic granite (D0003), the zircons (Fig. 3.14) have a grain size of $100-250 \mu \mathrm{m}$, with well euhedral platy or column textures, showing obvious magmatic oscillatory zoning. The D0003-15 zircon is subrounded, without oscillatory zones, obviously brighter in the interior, like cloud and mist, indicating its typical metamorphic origin. There are 16 dating points for D0003, and the obtained ${ }^{206} \mathrm{~Pb} /{ }^{238} \mathrm{U}$ ages can be divided into four groups. Th/U values of 8 dating points $(1-5,7,9,16)$ are $0.37-0.70$, showing the magmatic origin feature, and ${ }^{206} \mathrm{~Pb} /{ }^{238} \mathrm{U}$ weighted mean age is $140.4 \pm 3.3 \mathrm{Ma}$ $(\mathrm{MSWD}=3.3)($ Fig. 3.15), representing the crystallization

(b)

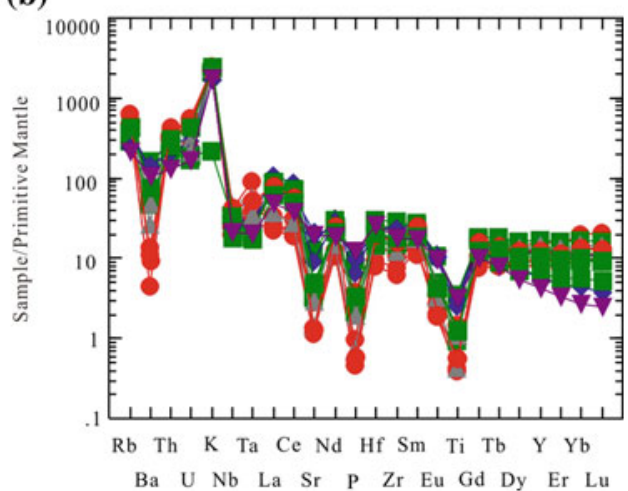

Fig. 3.13 Chondrite-normalized REE distribution mode (a) and primitive mantle-normalized trace-element spider diagram (b) for Tangshe composite pluton (the normalized values of chondrite and primitive mantle come from Sun and McDonough 1989) 


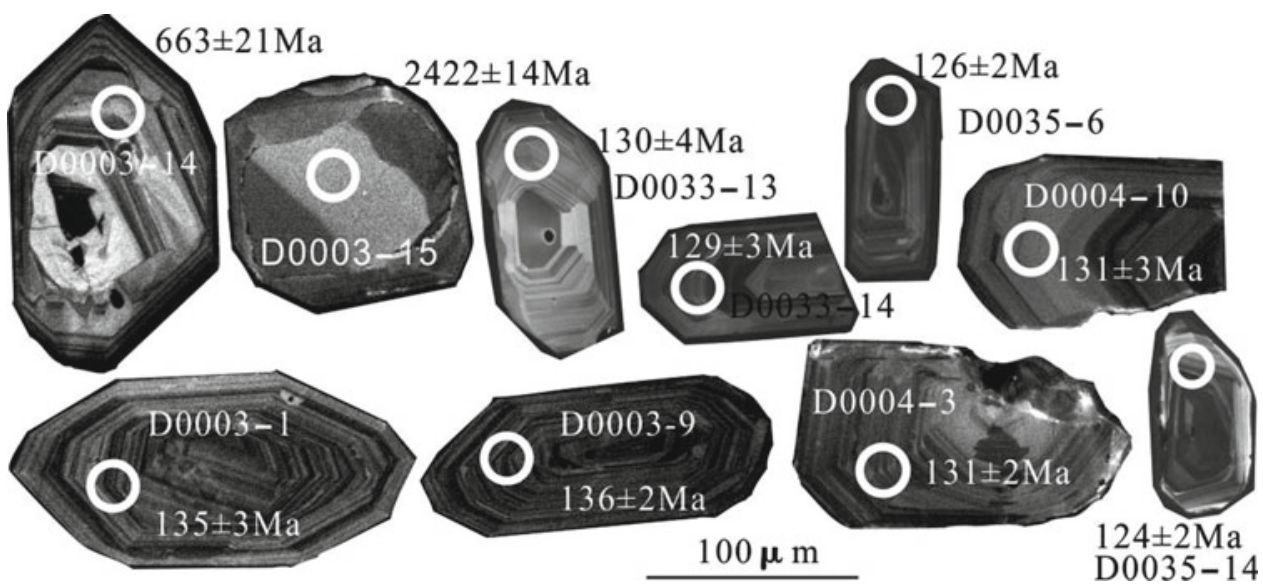

Fig. 3.14 $\mathrm{CL}$ images, analysis location , and $\mathrm{U}-\mathrm{Pb}$ age of some zircon points at Tangshe composite pluton
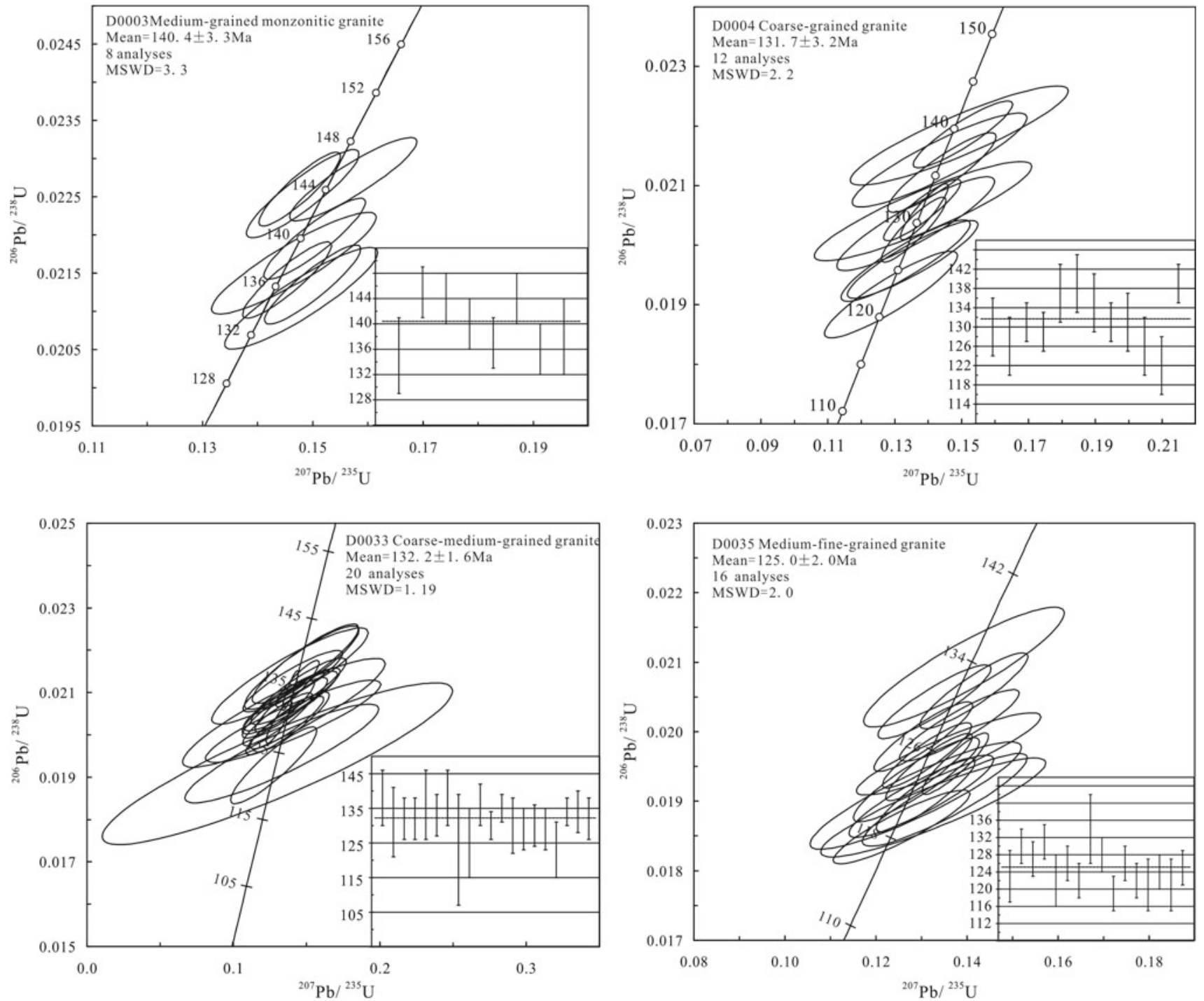

Fig. 3.15 Zircon U-Pb concordant diagrams for Tangshe composite pluton 
age of medium-grained monzonitic granite. Vavra et al. (1999) argued that, for metamorphic zircon, Th/U values are mainly less than 0.1 for most of them and may be greater than 0.7 for a few of them. For zircon D0003-15, Th/ $\mathrm{U}$ value is 1.72. By using the SHRIMP zircon U-Pb dating method, Gao et al. (2001) obtained that the age of trondhjemitic gneiss in Kongling high-graded metamorphic complex is 2947$2903 \mathrm{Ma}$, and argued the existence of the ancient basement of Yangtze block. For ancient zircon with age over $1400 \mathrm{Ma}$, due to $\mathrm{Pb}$ loss, ${ }^{207} \mathrm{~Pb} /{ }^{206} \mathrm{~Pb}$ ages are often choosed. Thus, the zircon age of D0003-15 is $2422 \pm 14 \mathrm{Ma}$, which may indicate that the ancient basement of Jiangnan Terrane existed in the survey area. ${ }^{206} \mathrm{~Pb} /{ }^{238} \mathrm{U}$ ages of another 6 dating points $(6$, $8,11-14)$ are $675-588 \mathrm{Ma}$, and in combination with the feature of CL image, it may be inherited zircon.

Zircon in medium-coarse and coarse-medium-grained syenogranite (D0004 and D0033) is basically in consistent form, euhedral-subhedral platy, the grain size is $80-150 \mu \mathrm{m}$, its length-width ratio is $2: 1-1: 1$, and almost all zircon have developed magmatic oscillatory zoning. There are totally 14 dating points for D0004. The ages from point 6 which is rather large and point 13 which is rather small are removed. The ${ }^{206} \mathrm{~Pb} /{ }^{238} \mathrm{U}$ weighted mean age of the remaining 12 points is $131.7 \pm 3.2 \mathrm{Ma}(\mathrm{MSWD}=2.2)$, representing the crystallization age of medium-coarse-grained syenogranite. There are totally 20 dating points for D0033, and the ${ }^{206} \mathrm{~Pb} /{ }^{238} \mathrm{U}$ weighted mean age is $132.2 \pm 1.6 \mathrm{Ma}$ $(\mathrm{MSWD}=1.19)$, representing the crystallization age of medium-grained syenogranite. Th/ $\mathrm{U}$ values of 12 zircons in sample D0004 and 20 zircon in sample D0033 are 0.37-0.76 and $0.30-0.83$, respectively, featuring magmatic orgin.

In fine-grained syenogranite (D0035), the zircon grain size is $60-120 \mu \mathrm{m}$, its length-width ratio is $2: 1-1: 1$, euhedralsubhedral, and zircon has well-developed magmatic oscillatory zoning, and the phenomenon of decrystallization may be seen in a few zircons. There are totally 18 dating points for $\mathrm{D} 0035$, of which the ${ }^{206} \mathrm{~Pb} /{ }^{238} \mathrm{U}$ age of point 15 is $113 \pm 3 \mathrm{Ma}$, greatly smaller than those of other dating points, which may represent a thermal event at the end of crystallization stage. The age data of point 17 are problematic, possibly resulting from a mistake during the experimental operation. After the ages of point 15 and 17 are removed, the ${ }^{206} \mathrm{~Pb} /{ }^{238} \mathrm{U}$ weighted mean age of the remaining 16 points is $132.2 \pm 2.0 \mathrm{Ma}(\mathrm{MSWD}=2.0)$, representing the crystallization age of fine-grained syenogranite. Th/U value of 16 dating zircons in sample D0035 is 0.55 , and in combination with the features of CL image, it is considered that the zircon in fine-grained granite is magmatic orgin.

In conclusion, Tangshe composite pluton has conspicuously experienced three stages of magmatism, the early stage is medium-grained monzonitic granite $(140.4 \pm 3.3 \mathrm{Ma})$, the middle stage is medium-coarse-grained and coarse-medium-grained syenogranite $\quad(132.2 \pm 1.6 \mathrm{Ma}-$ $131.7 \pm 3.2 \mathrm{Ma})$, and the later stage is fine-grained syenogranite $(125.0 \pm 2.0 \mathrm{Ma})$.

\subsubsection{Xianxia Composite Pluton}

\section{Geological Features}

Xianxia composite pluton is located in the southwest of the survey area; about $25 \mathrm{~km}$ in length and $1.5-7.5 \mathrm{~km}$ in width, extended in southwest into Anhui Province, and its outcrop area is $84.18 \mathrm{~km}^{2}$. The pluton is under joint control of NE-strike Maotan-Luocun Fault and Shiling-Shangmei Forest Farm anticlinorium, propagated in NE-strike generally and narrows gradually from SW to NE; its northwestern side is in intrusive contact with the Neoproterozoic-Paleozoic strata, and its southeastern side is in intrusive contact with the Paleozoic strata or in NE-strike fault contact with the late Mesozoic volcanic rocks (Fig. 3.16). The composite pluton obviously has experienced intrusions in multiple stages. From early to late stages, magma intruded from southwest to northeast, and the rocks are sequentially (medium-grained, fine-grained, and megacrystic porphyritic) monzonitic granite $\rightarrow$ (medium-coarse, coarse-medium, and fine-grained) syenogranite $\rightarrow$ (medium-coarse-grained) quartz syenite, and later, it was intruded by plenty of fine-grained granite, aplite, quartz syenite, diorite porphyrite, and diabase veins, etc.

\section{Petrological Features}

The features of lithological compositions in Xianxia composite pluton are listed in Table 3.2. In the early stage, the center of megacrystic porphyritic monzonitic granite surged and intruded into medium-grained monzonitic granite, and the contact boundary is not clear for strong weathering, with the "abrupt change" of both seen within $0.5-1 \mathrm{~m}$ locally. Medium-grained monzonitic granite xenolith is developed in megacrystic porphyritic monzonitic granite of Zhongguling. Small megacrystic porphyritic monzonitic granite apophysis is intruded into medium-grained monzonitic granite stock, and it is visible on the contact zone that biotite is distributed as strip-like flow-line structure (Fig. 3.17). The rock gradually transitioned to coarse-medium-grained porphyritic monzonitic granite at the margin of NE-strike fault contact zone near the Shangyan Reservoir. The feldspar is generally long column-like, showing a certain directional arrangement, and the quartz minerals in the marginal rocks show cataclastic texture due to later fractures.

\section{Medium-grained monzonitic granite}

The rock is gray, mainly consisting of plagioclase (35$40 \%)$, K-feldspar (25-35\%), quartz (20-25\%), biotite (5$10 \%)$, as well as a handful of magnetite, apatite, and zircon, etc. The grain size is $1-3 \mathrm{~mm}$, casually $3-6 \mathrm{~mm}$. The biotite-bearing MMEs (Fig. 3.18a) and megacrystic plagioclase could be locally seen, and the plagioclase shows zoning texture (Fig. 3.18g). 


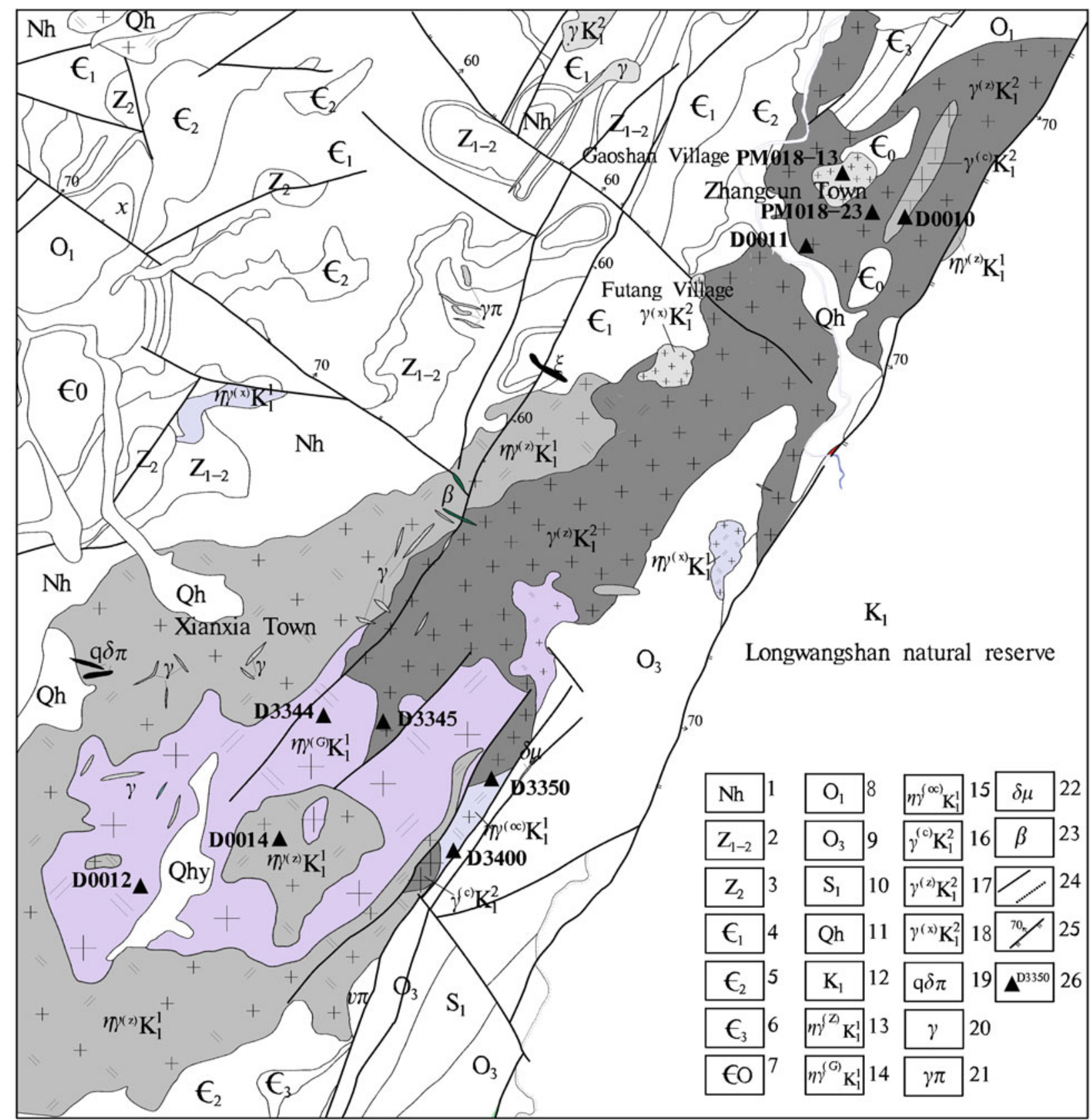

1-Nanhuaian 2-Sinian 3-Upper sinian 4-Early Cambrian 5-Middle Cambrian 6-Later Cambrian

7-Later Cambrian - early Ordovician 8- Early Ordovician 9-Later Ordovician 10-Lower silurian 11-Quaternary 12-Early Cretaceous 13-Medium-grained monzonitic granite 14-Megacrystic-porphyritic monzonitic granite 15-Coarse -grained porphyriticmonzonitic granite 16-Medium-coarse-grained syenogranite 17-Coarse-medium-grained syenogranite 18-Fine-grained syenogranite 19-Quartz diorite porphyry 20-Granite 21-Granite porphyry 22-Dioritic porphyrite 23-Diabase 24-Geological boundary/ithofacies boundary 25-Fault 26-Sampling location and number

Fig. 3.16 Regional geological sketch map of Xianxia composite pluton

\section{Megacrystic porphyritic monzonitic granite}

The rock is light gray-light pink. The phenocryst is mainly plagioclase (3-5\%) and K-feldspar (5-7\%), in the size of $1-$
$2 \mathrm{~cm}$ (Fig. 3.18b, h), and matrix mainly is plagioclase (30$35 \%)$, K-feldspar (20-25\%), quartz (25-30\%), biotite (5$10 \%$ ), and a handful of apatite and zircon, etc., $1-3 \mathrm{~mm}$ in size; the lithology at the margin of the NE-strike fault contact 
Table 3.2 Lithological composition and geological features of the Xianxia composite pluton

\begin{tabular}{|c|c|c|c|}
\hline Lithology & Contact relationship & Mineral assemblage & Fabric feature \\
\hline $\begin{array}{l}\text { Medium- grained } \\
\text { monzonitic granite }\end{array}$ & $\begin{array}{l}\text { The periphery of southwest part } \\
\text { and the central top cap is in } \\
\text { intrusive contact with wall-rock } \\
\text { strata }\left(345^{\circ} \angle 20^{\circ}\right) \text {, and locally } \\
\text { fault contact. }\end{array}$ & $\begin{array}{l}\text { Plagioclase (35-40\%), K-feldspar } \\
(25-35 \%) \text {, quartz }(20-25 \%) \text {, } \\
\text { biotite (5-10\%), a handful of } \\
\text { magnetite, apatite, and zircon, etc. }\end{array}$ & $\begin{array}{l}\text { Light gray, fine-medium-grained } \\
\text { subhedral granular texture, } \\
\text { generally } 1-3 \mathrm{~mm} \text { in size, } \\
\text { occasionally } 3-6 \mathrm{~mm} \text {, locally seen } \\
\text { biotite-bearing MMEs and } \\
\text { megacrystic plagioclase, and } \\
\text { plagioclase has developed zoning } \\
\text { texture }\end{array}$ \\
\hline $\begin{array}{l}\text { Phenocryst-porphyritic } \\
\text { monzonitic granite }\end{array}$ & $\begin{array}{l}\text { The central part of its southwest } \\
\text { section is in gushing intrusive } \\
\text { contact with medium-grained } \\
\text { monzonitic granite at the margin. }\end{array}$ & $\begin{array}{l}\text { Phenocryst: plagioclase }(3-5 \%) \text {, } \\
\text { K-feldspar }(5-7 \%) \text {; matrix: } \\
\text { plagioclase }(30-35 \%) \text {, K-feldspar } \\
(20-25 \%) \text {, quartz }(25-30 \%) \text {, and } \\
\text { biotite }(5-10 \%)\end{array}$ & $\begin{array}{l}\text { Light gray-light pink, in } \\
\text { facies-change zonation with } \\
\text { medium-grained monzonitic } \\
\text { granite, megacrystic porphyritic is } \\
\text { subhedral granular, and phenocryst } \\
\text { is about } 1-2 \mathrm{~cm} \text { in size; matrix is } \\
\text { about } 1-3 \mathrm{~mm} \text { in size }\end{array}$ \\
\hline $\begin{array}{l}\text { Coarse-medium-grained } \\
\text { porphyritic monzonitic } \\
\text { granite }\end{array}$ & $\begin{array}{l}\text { Mainly distributed in southwest } \\
\text { section at the intersection of } \\
\text { medium-grained granite and } \\
\text { megacrystic porphyritic } \\
\text { monzonitic granite, or distributed } \\
\text { near the fault edge in southeast } \\
\text { section }\end{array}$ & $\begin{array}{l}\text { Plagioclase (35-40\%), K-feldspar } \\
(25-35 \%) \text {, quartz }(20-25 \%) \text {, a } \\
\text { handful of apatite, and zircon, etc. }\end{array}$ & $\begin{array}{l}\text { Light pink, coarse-medium-grained } \\
\text { porphyritic granitoid texture; the } \\
\text { grain size is } 3-8 \mathrm{~mm} \text {, feldspar is } \\
\text { generally long column-like and had } \\
\text { a certain directionally arrangement, } \\
\text { and rocks at the margin minerals } \\
\text { such as quartz have developed } \\
\text { cataclastic texture due to later } \\
\text { fractures }\end{array}$ \\
\hline $\begin{array}{l}\text { Coarse-medium-grained } \\
\text { syenogranite }\end{array}$ & $\begin{array}{l}\text { Mainly distributed in the middle } \\
\text { and northeast sections of the } \\
\text { pluton, and in intrusive contact } \\
\text { with monzonitic granite in } \\
\text { southwest section }\end{array}$ & $\begin{array}{l}\text { Quartz }(25-35 \%), \text { K-feldspar }(35- \\
40 \%) \text {, plagioclase }(15-20 \%), \\
\text { biotite }(5-10 \%)\end{array}$ & $\begin{array}{l}\text { Light pink, coarse-medium-grained } \\
\text { texture, with } 1-7 \mathrm{~mm} \text { in size, and } \\
\text { from southwest to northeast, the } \\
\text { grain size gradually decreased }\end{array}$ \\
\hline $\begin{array}{l}\text { Fine-grained } \\
\text { syenogranite }\end{array}$ & $\begin{array}{l}\text { Small apophysis or vein, intruded } \\
\text { in coarse-medium-grained } \\
\text { syenogranite in northeast section. }\end{array}$ & $\begin{array}{l}\text { Quartz }(30-35 \%), \text { K-feldspar }(35- \\
40 \%) \text {, plagioclase }(15-20 \%), \\
\text { biotite }(3-5 \%)\end{array}$ & $\begin{array}{l}\text { Light pink, fine-grained texture, } \\
\text { grain size } 0.5-2 \mathrm{~mm}\end{array}$ \\
\hline $\begin{array}{l}\text { Coarse-grained quartz } \\
\text { syenite }\end{array}$ & $\begin{array}{l}\text { Small apophysis, intruded in } \\
\text { coarse-medium-grained } \\
\text { syenogranite }\end{array}$ & $\begin{array}{l}\text { Quartz }(10-15 \%), \text { K-feldspar }(65- \\
70 \%), \text { plagioclase }(5-10 \%) \text {, biotite } \\
(1-3 \%)\end{array}$ & $\begin{array}{l}\text { Coarse-grained granitic texture, } \\
\text { grain size } 5-8 \mathrm{~mm}\end{array}$ \\
\hline
\end{tabular}

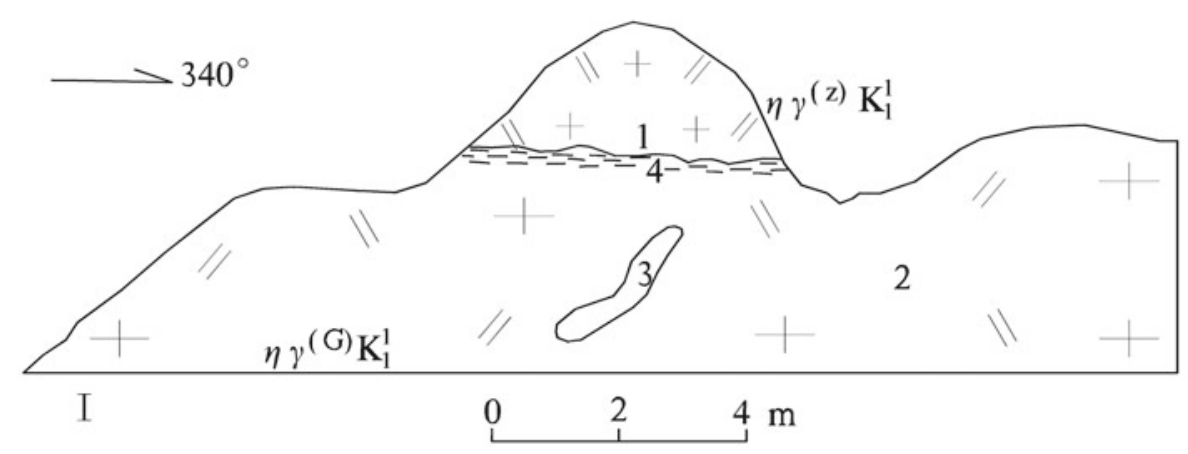

1-Medium-grained( porphyritic) monzonitic granite 2-Megacrystic porphyritic monzonitic granite 3-Xenolith 4-Stream-surface structure 5-Biotite distributed as strip-like flowline structure

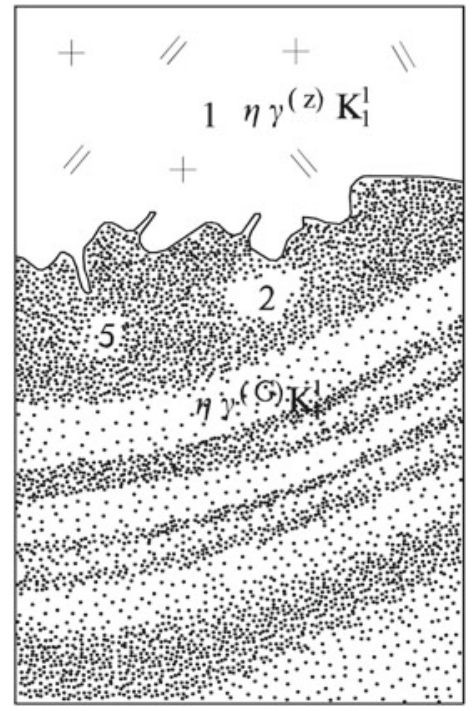

Fig. 3.17 Contact relationship between medium-grained monzonitic granite and megacrystic porphyritic monzonitic granite in Majiafan area 
(a)

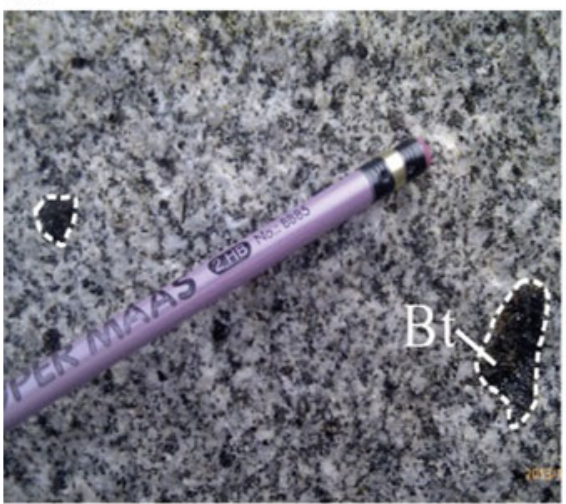

(d)

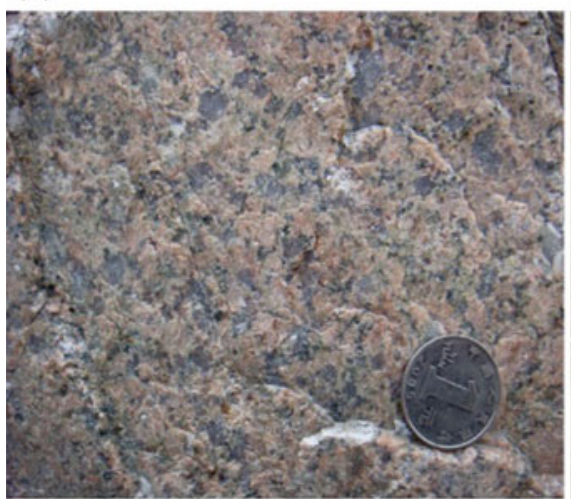

(g)

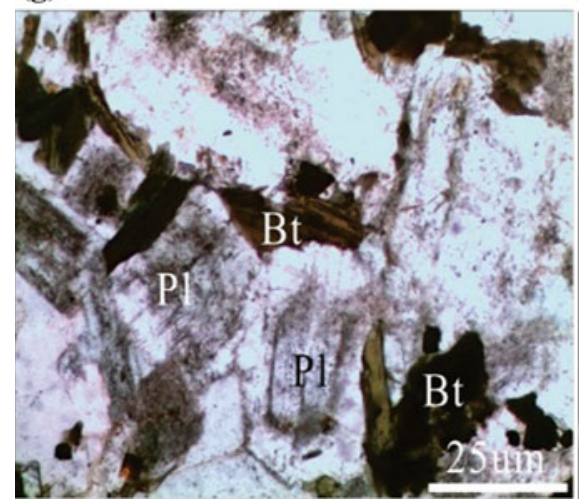

(b)

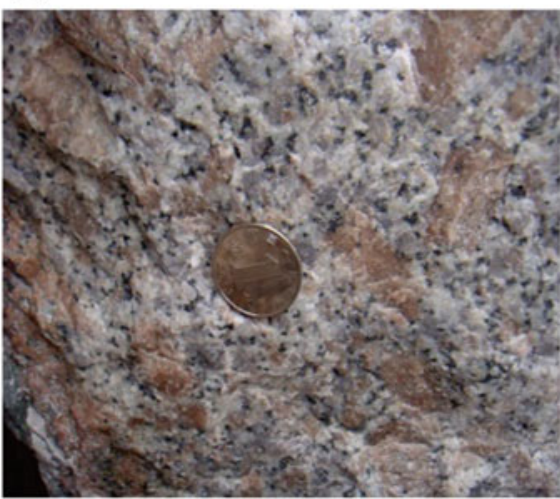

(e)

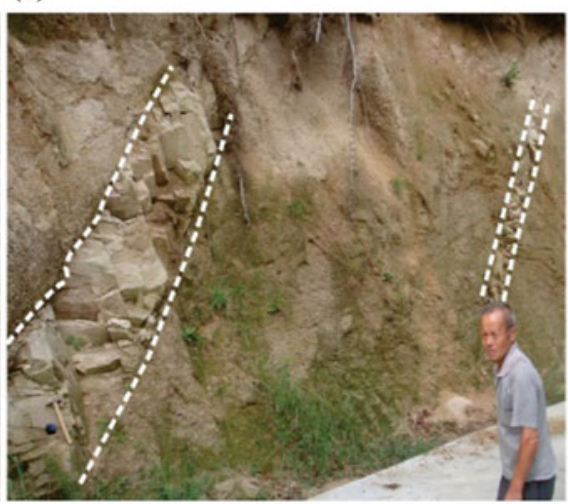

(h)

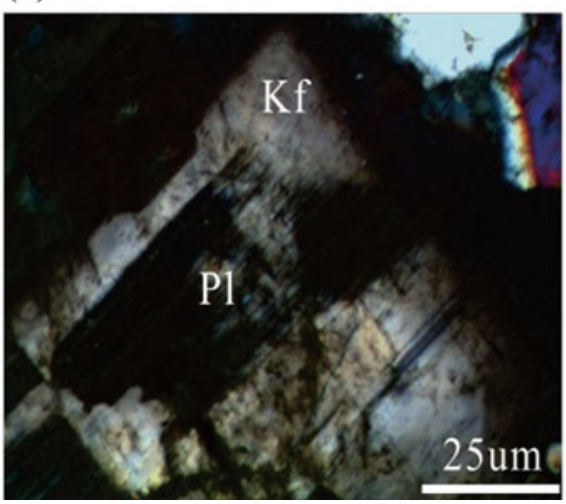

(c)

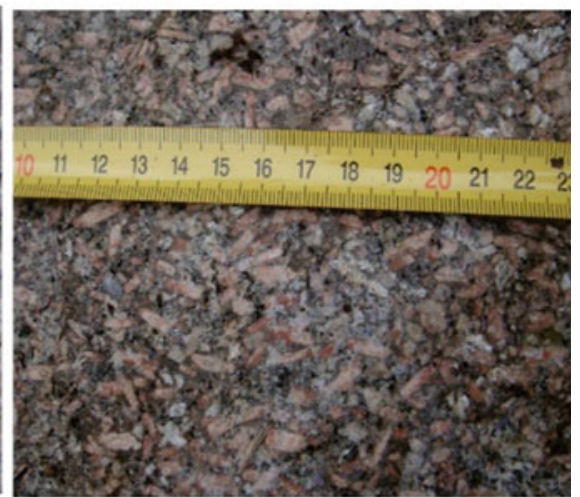

(f)

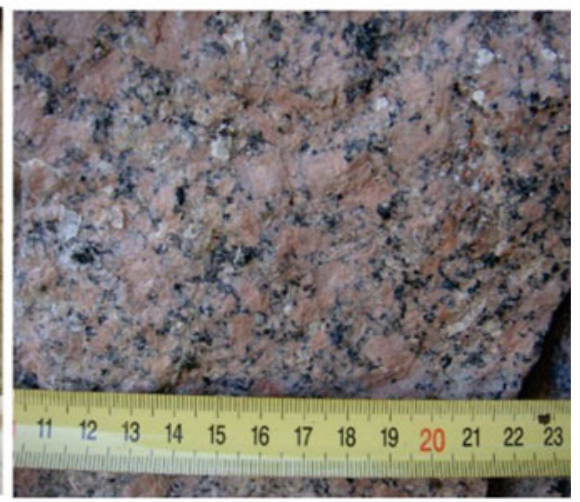

(i)

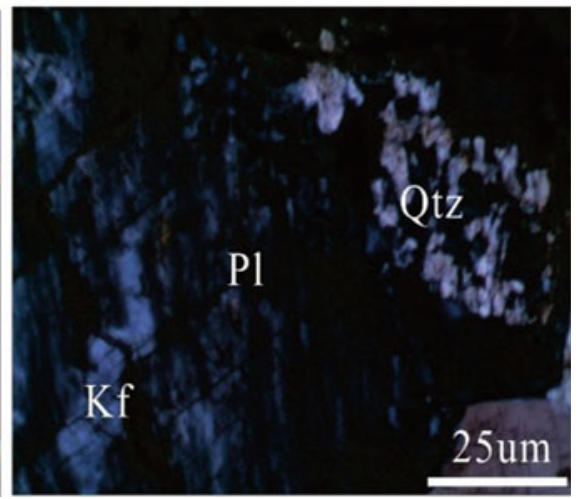

Fig. 3.18 Outcrops and micrographs images showing lithological features of the Xianxia composite pluton. a biotite-bearing MMEs in medium-grained monzonitic granite; b K-feldspar megacryst in megacrystic porphyritic monzonitic granite; c medium-coarse-grained porphyritic monzonitic granite long-strip shaped feldspar; d medium-coarse-grained syenogranite; e fine-grained syenogranite

zone in the east side is transitioned to coarse-medium-grained porphyritic monzonitic granite, feldspar is generally long column-like and had a certain directionally arrangement (Fig. 3.18c), and the quartz in the margin rocks developed cataclastic texture due to later fractures (Fig. 3.18i). vein intruded in medium-grained monzonitic granite; $\mathbf{f}$ coarse-grained quartz syenite; $\mathbf{g}$ zoning texture plagioclase in medium-grained monzonitic granite; $\mathbf{h}$ feldspar phenocryst in megacrystic porphyritic monzonitic granite (K-feldspar wrapping plagioclase); i K-feldspar inside plagioclase in medium-coarse-grained porphyritic monzonitic granite, and quartz cataclastic phenocryst affected by later fracture

\section{Coarse-medium-grained granite}

The area was intruded by later medium-coarse-grained syenogranite in the northeastern section, and from southwest to northeast the mineral grain size of the intrusion becomes smaller and the content of biotite decreases. The 
intrusion intruded as tree branch shape in the contact zone of monzonitic granite. Coarse-medium-grained granite is light pink, mainly consisting of quartz (25-35\%), K-feldspar (35$40 \%$ ), plagioclase (15-20\%), and biotite (5-10\%), in the size of 1-7 mm (Fig. 3.18d). Fine-grained syenogranite occurred as small apophysis intruding into medium-coarse-grained syenogranite, with each pluton generally about $0.5-1 \mathrm{~km}^{2}$. It is light pink, and mainly composed of quartz (30-35\%), K-feldspar (35-40\%), plagioclase (15-20\%), and biotite (3$5 \%$ ), showing a grain size of $0.5-2 \mathrm{~mm}$.

\section{Wall-rock Alteration}

The northwestern section of the pluton, generally as medium-grained monzonitic granite or coarse-mediumgrained syenogranite, is in intrusive contact with the Neoproterozoic-Paleozoic strata. The boundary of the contact zone is irregularly, generally dipping outward trend, and the dipstrike of the contact surface is $310^{\circ}-340^{\circ} \angle 20^{\circ}-60^{\circ}$, and locally in NE-strike fault contact. The southeastern section of the pluton is in intrusive contact with the Paleozoic strata, or in NE-strike fault contact with the Early Cretaceous volcanic rocks in the Huangjian Formation. It was controlled by the NE-strike Maotan-Luocun fault before and after magmatism. In the southeastern section of the pluton, argillaceous and siliceous rocks at the contact zones were strongly hornfelsic, and the secondary NW-strike fault was filled with silicification-fluorite veins. In the northeastern section, the strong skarnization alteration was developed in the Cambrian carbonate strata near the NW contact zone or carbonate xenolith in the pluton. The NE-strike fracture in the pluton was filled with quartz-fluorite veins. In the southeastern side, the wall-rock volcanic rock alteration was weak, with slightly silicification and argillization just locally.

\section{Geochemical Features}

The Xianxia composite pluton is high in $\mathrm{SiO}_{2}$ content (67.6$76.11 \%$ ), enriched in alkali (Alk $=\mathrm{K}_{2} \mathrm{O}+\mathrm{Na}_{2} \mathrm{O}$, 7.169.91\%) (Fig. 3.19), and low in $\mathrm{P}_{2} \mathrm{O}_{5}(0.03-0.3 \%)$ and $\mathrm{TiO}_{2}$ $(0.17-0.55 \%)$. In general, compared with later medium-coarse-grained and fine-grained syenogranite, the early medium-grained and the megacrystic porphyritic monzonitic granite showed a trend of increase in $\mathrm{SiO}_{2}$ and $\mathrm{K}_{2} \mathrm{O}$, and $\mathrm{K}_{2} \mathrm{O} / \mathrm{Na}_{2} \mathrm{O}$ ratio, but a trend of contents decrease in $\mathrm{TiO}_{2}, \mathrm{TFeO}, \mathrm{MgO}, \mathrm{CaO}$, and $\mathrm{Na}_{2} \mathrm{O}$. A/CNK is mostly $0.95-1.03$. A/CNK of medium-coarse-grained porphyritic monzonitic granite of D3350 is higher (1.18) possibly due to later fracturing and $\mathrm{K}$-feldspathization locally. As a whole, early monzonitic granite is metaluminous, high $\mathrm{K}$

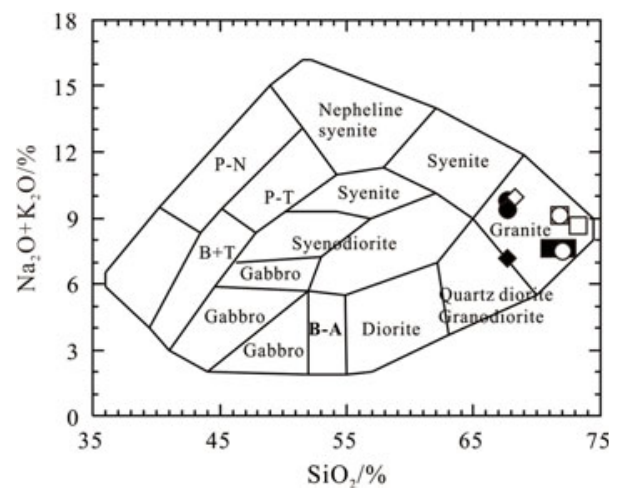

Fig. 3.19 $\mathrm{SiO}_{2}-\mathrm{K}_{2} \mathrm{O}$ diagram for Xianxia composite pluton (its legends are the same as those in Fig. 3.20)

calc-alkaline, while the late-stage syenogranite is metaluminous-peraluminous and shoshonitic (Fig. 3.20a, b), which are similar to late coarse-grained quartz syenite veins.

For the early medium-grained and megacrystic porphyritic monzonitic granite, the $\sum$ REE content is (112.66$193.55) \times 10^{-6}$, LREE/HREE ratio is $10.39-16.90, \delta \mathrm{Eu}$ is $0.52-0.75$, LREE and HREE was strongly differentiated. The chondrite-normalized REE patterns are strongly dipping rightward, medium negative Eu anomaly, enriched in $\mathrm{Rb}, \mathrm{Th}, \mathrm{U}$, and $\mathrm{K}$, etc., depleted in elements such as $\mathrm{Ba}, \mathrm{Sr}, \mathrm{Nb}, \mathrm{P}$, and $\mathrm{Ti}$ (Fig. 3.21a, b). For the late medium-coarse-grained and fine-grained syenogranite in the northeastern section of the pluton, $\sum$ REE content is (155.87-244.51) $\times 10^{-6}$, LREE/HREE ratio is $5.02-13.74, \delta \mathrm{Eu}$ is $0.22-0.67$, LREE and HREE were weakly differentiated, the chondrite-normalized REE patterns were weakly dipping rightward, strongly negative Eu anomaly, similarly showing enrichment in $\mathrm{Rb}, \mathrm{Th}, \mathrm{U}$, and $\mathrm{K}$, strongly depleted in elements such as $\mathrm{Sr}, \mathrm{Nb}, \mathrm{P}$, and $\mathrm{Ti}$, possibly associated with crystal segregation of minerals such as plagioclase, apatite, ilmenite, rutile, and sphene during magmatism, and conforming to the gradually increasing differentiation. The REE distribution curve and trace element features in the late coarse-grained quartz syenite veins are greatly different from those of early monzonitic granite but similar to those of later granite, indicating their similar magma source.

In the Xianxia composite pluton, $\left({ }^{86} \mathrm{Sr} /{ }^{87} \mathrm{Sr}\right)_{i}$ is 0.70988 0.70455 and $\varepsilon \mathrm{Nd}(t)$ is -5.14 to -8.87 , and from the early monzonitic granite to the late syenogranite both have a trend of decrease, and $T_{\mathrm{DM} 2}$ is low $(1.36-1.65 \mathrm{Ga})$; they are similar to $\left({ }^{86} \mathrm{Sr} /{ }^{87} \mathrm{Sr}\right)_{\mathrm{i}}(0.71030-0.70613)$ and $\varepsilon \mathrm{Nd}(t)(-3.75$ to -6.4$)$ of the Mogan Mount granite pluton in the northern Zhejiang Province (Zhang et al. 2012) or slightly lower than $\left({ }^{86} \mathrm{Sr} /{ }^{87} \mathrm{Sr}\right)_{\mathrm{i}}(0.71010-0.70960)$ and $\varepsilon \mathrm{Nd}(t)(-6.28$ to -7.32$)$ of Jinde granodiorite pluton in the southern Anhui Province (Zhou et al. 2014). 
(a)

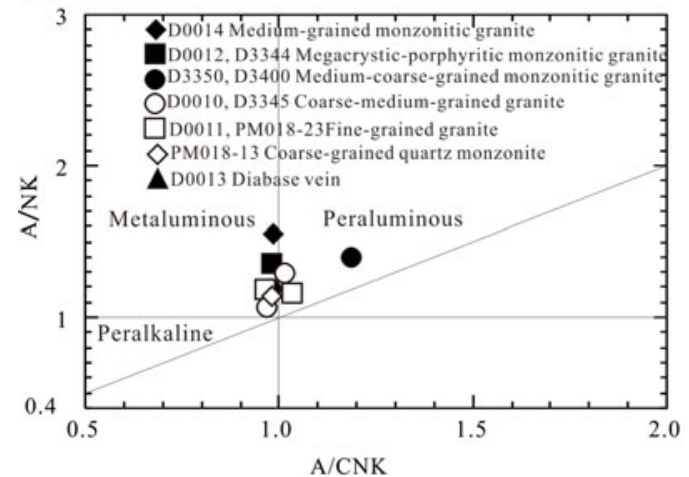

(b)

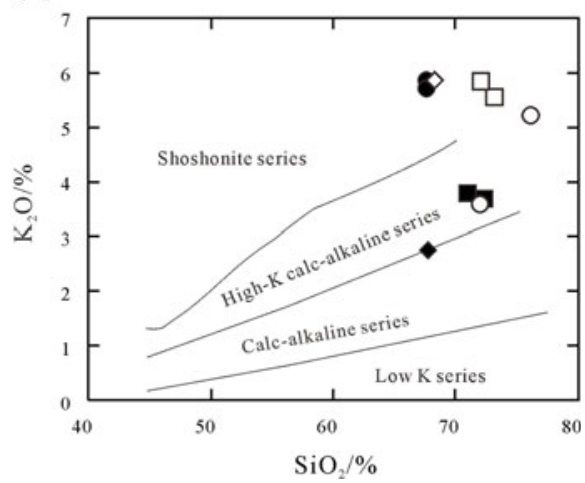

Fig. 3.20 $\mathrm{SiO}_{2}-\mathrm{Na}_{2} \mathrm{O}+\mathrm{K}_{2} \mathrm{O}$ and $\mathrm{A} / \mathrm{CNK}-\mathrm{A} / \mathrm{NK}$ diagrams for Xianxia composite pluton

(a)

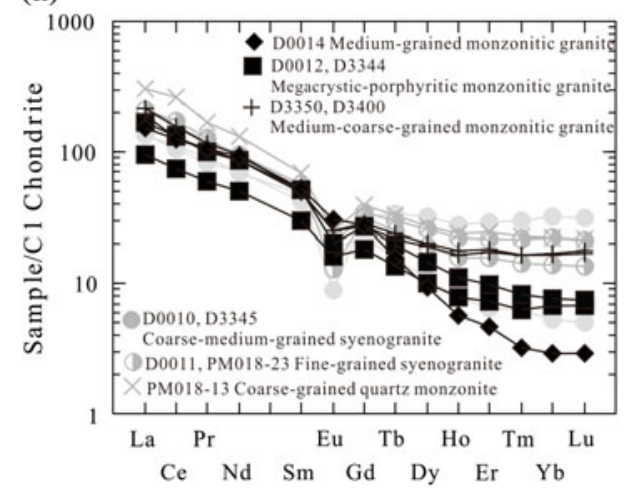

(b)

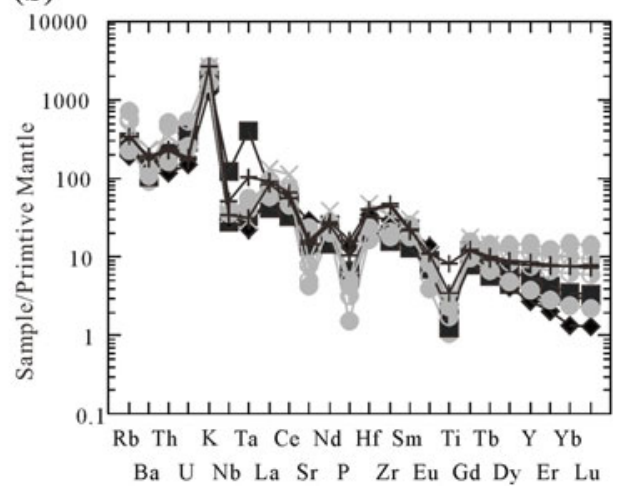

Fig. 3.21 Chondrite-normalized REE distribution mode (a) and primitive mantle-normalized trace element spider diagram (b) for the Xianxia composite pluton (the normalized values of chondrite and primitive mantle come from Sun and McDonough 1989)

\section{Isotope geochronology}

In the Xianxia pluton, zircon in main lithologies is mostly irregular long strip, 100-200 $\mu \mathrm{m}$ in length and with about 2:1 length-width ratio. Zircon developed magmatic oscillatory zoning and very few of zircons have developed inherited core (Fig. 3.22). The Th contents in zircons from the medium-grained monzonitic granite, the megacrystic porphyritic monzonitic granite, the medium-coarse-grained syenogranite, and the fine-grained syenogranit are (8$310) \times 10^{-6},(83-566) \times 10^{-6},(28-220) \times 10^{-6}$, and $(72-$ $466) \times 10^{-6}$, respectively; the $U$ contents are $(226-$ $1041) \times 10^{-6},(175-1004) \times 10^{-6},(40-284) \times 10^{-6}$, and $(80-433) \times 10^{-6}$, respectively; the $\mathrm{Th} / \mathrm{U}$ ratios are 0.02
$0.83,0.19-0.91,0.70-1.29$, and $0.36-1.08$, respectively, showing a typical magmatic zircon (Hoskin and Schaltegger 2003). Zircon dating points are mostly projected on or near the concordant curve, and ${ }^{206} \mathrm{~Pb} /{ }^{238} \mathrm{U}$ weighted mean ages are $145.1 \pm 1.2 \mathrm{Ma} \quad(\mathrm{MSWD}=1.8), \quad 144.2 \pm 0.97 \mathrm{Ma}$ $(\mathrm{MSWD}=0.94), \quad 131.7 \pm 1.6 \mathrm{Ma} \quad(\mathrm{MSWD}=2.3), \quad$ and $130.8 \pm 1.6 \mathrm{Ma}(\mathrm{MSWD}=1.4$ ), respectively (Fig. 3.23), indicating that the pluton was intruded in Early Cretaceous. The obtained ages can be divided into two stages (145.1144.2 Ma and 131.7-130.8 Ma). Notably in the early monzonitic granite, the ${ }^{206} \mathrm{~Pb} /{ }^{238} \mathrm{U}$ ages of some sample points concentrate in three stages: 1368-704 Ma (D0014-7, D0014-14, D0014-15, D0012-3), 497.8-268 Ma (D0014-9, D0014-2, D0012-4, D0012-5), and 200.1-163 Ma

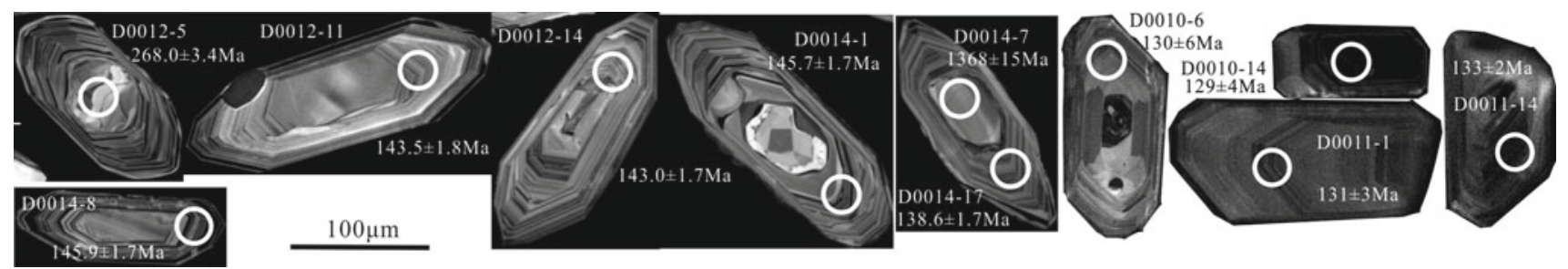

Fig. 3.22 Typical zircon CL images, dating points, and ages of the rocks in the Xianxia composite pluton 

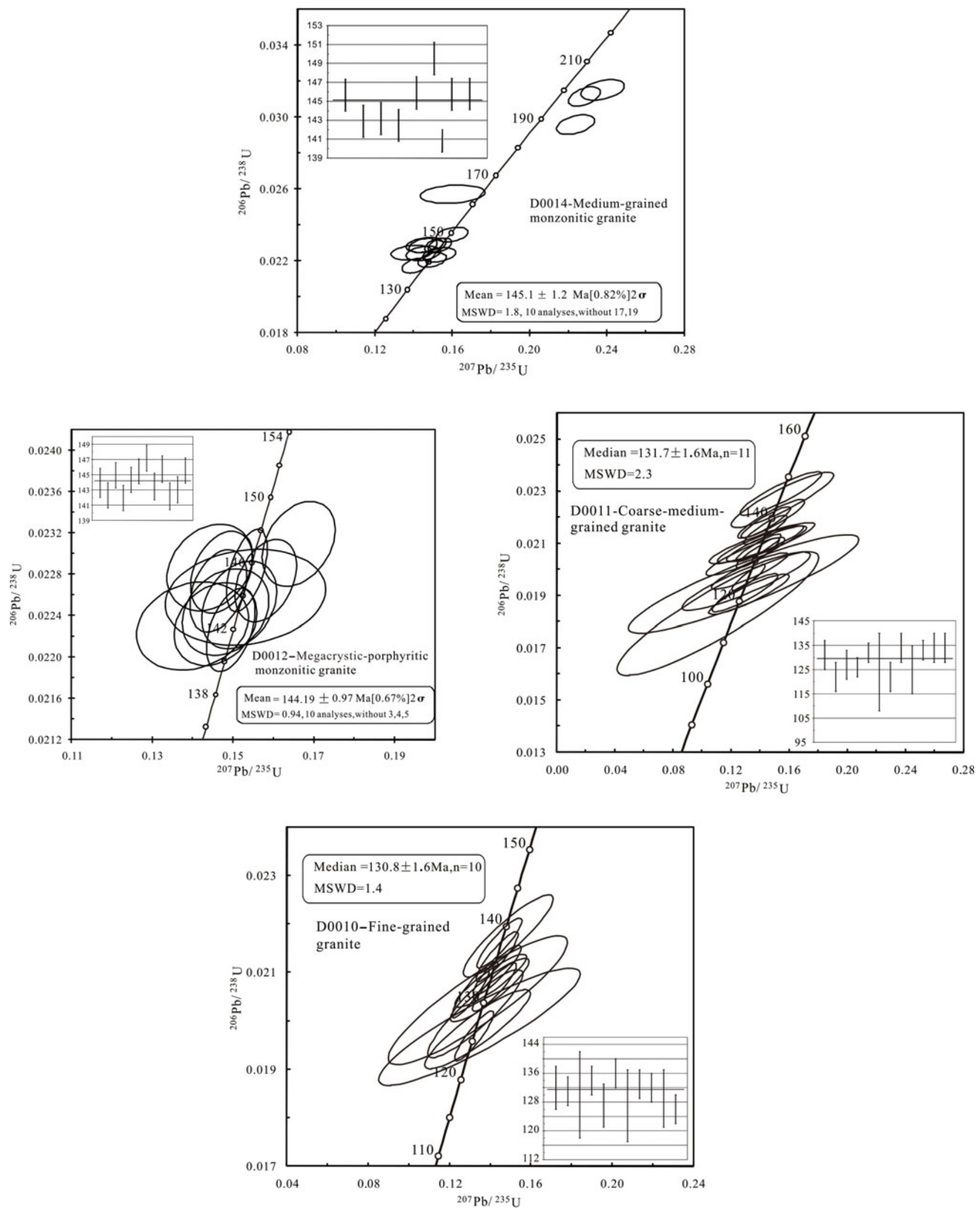

Fig. 3.23 Zircon $\mathrm{U}-\mathrm{Pb}$ concordant diagrams of main rocks of the Xianxia composite pluton 
(D0014-13, D0014-18, D0014-6, D0014-16), which possibly indicate that during the emplacement along the NE-strike fault, the upwell magma captured zircon or inherited core from the Middle Neoproterozoic to the Middle-Late Jurassic basement and wall rocks. For the later syenogranite, the ${ }^{206} \mathrm{~Pb} /{ }^{238} \mathrm{U}$ ages in a few sample points involved four stages: $720 \mathrm{Ma}$ (D0011-7), 154-145 Ma (D0011-18, D0011-15, D0011-19), 140-136 Ma (D0010-1, D0011-5, D0011-16, D0010-8, D0010-5, D0010-10), and 119-117 Ma (D0010-2, D0011-8). The first two stages indicated it also captured zircon or inherited core of the Neoproterozoic basement and the early monzonitic granite. The presence of the three-stage ages possibly meant that, the syenogranite emplacement crystallization last longer or inherited zircon growth of early monzonitic granite.

\subsubsection{Wushanguan Composite Pluton}

\section{Geological Features}

Wushanguan composite pluton is situated in the adjacent area of Yuhang District of Hangzhou and Shanchuan Town of Anji County, which is in the eastern part of the survey area. The pluton is generally NW-strike, about $10 \mathrm{~km}$ in length and $2-8 \mathrm{~km}$ in width, outcrop areas $64 \mathrm{~km}^{2}$. Regionally, the pluton intruded into the northeastern margin of the volcanic low-lying land of Tianmu Mount was jointly controlled by the NE-strike Zaoxi-Mogan Mount Fault and the NW-strike fault.

\section{Petrological Features}

The Wushanguan pluton is mainly composed of the first stage medium-grained (biotite) monzonitic granite, the second stage medium-coarse-grained and medium-grained syenogranite, the third stage megacrystic porphyritic monzonitic granite (a handful of) and fine-grained syenogranite, and the fourth stage medium-grained syenite.

\section{Medium-grained monzonitic granite}

The first stage irregular and NE-strike medium-grained monzonitic granite are mainly distributed in the northwestern part of the pluton. The color of fresh rock is light pinklight offwhite, while the weathered rock is light gray yellowlight gray but with smooth and flat surface. The rocks are fine-medium-grained granitic texture and massive structure. The typical mineral assemblage is composed of plagioclase (30-35\%), K-feldspar (25-30\%), quartz (25-30\%), biotite $(10-15 \%)$, and hornblende $(2-4 \%)$. The grain size is mainly 2-5 mm, and minor $<2 \mathrm{~mm}$. Plagioclase is subhedral plate or column and developed Na-feldspar bicrystal and zoning structure. K-feldspar is perthite, irregular plate, with plagioclase replacement and inclusions. Quartz is anhedral granular, unevenly distributed among feldspar. Biotite is dark brown, platy or laminated, a small portion alterated into chlorite along the joints. Hornblende is light green and long column-like. The MMEs are oval, long strip, or irregular, 1$30 \mathrm{~cm}$ with the size, composed of biotite or biotite-plagioclase in the pluton.

\section{Medium-coarse-grained and medium-grained syenogranite}

The second stage medium-coarse-grained and mediumgrained syenogranite is located in southeastern part of the composite pluton, which is mainly distributed in the area of the Luniao Town, such as the Xianbaikeng Reservoir, Shangougou Village, and Taigongtang Village. Its outrcrop area is NEE, NE, and NW-strike, irregular shapes, about $20 \mathrm{~km}^{2}$. The rocks are light gray. The weathered surface is coarse and full of sags and crests, mineral grains such as quartz show embossment. It is coarse-medium and medium-coarse-grained granitic texture, massive structure, and from southeast to northwest part of the pluton, the grain sizes gradually changed from medium-coarse to coarse-medium. The main mineral assemblages are $45-55 \%$ K-feldspar, $15-25 \%$ plagioclase, $25-35 \%$ quartz and $1 \%$ biotite, etc.; the grain size is generally $2-7 \mathrm{~mm}$, and 7-10 mm for a handful, and locally K-feldspar looks porphyritic (1$2 \mathrm{~cm} \times 1-1.5 \mathrm{~cm})$. K-feldspar is mainly orthoclase, wide plate, Carlsbad bicrystals occurred. Plagioclase is hypidiomorphic wide plate, plate-column, and Na-feldspar bicrystal visible. Quartz is mostly anhedral granular, distributed rather evenly, and a handful of quartz is inlaid in a certain shape in $\mathrm{K}-\mathrm{Na}$-feldspar formed graphic texture. Rocks are rather weathered and broken locally, and plagioclase alterated into kaolinization and epidotization.

\section{Megacrystic porphyritic monzonitic granite}

In the third stage, a handful of lump $(2-8 \mathrm{~m} \times 2-8 \mathrm{~m})$ megacrystic porphyritic monzonitic granite intruded into medium-coarse-grained syenogranite, locally wrapping ellipse small-lump-like xenolith of medium-coarse-grained syenogranite $(5-50 \mathrm{~cm} \times 5-50 \mathrm{~cm})$ (Figs. 3.24, 3.25 and 3.26).

\section{Fine-grain syenogranite}

The fine-grain syenogranite, in the shape of small stock or vein, intruded into medium-coarse and coarsemedium-grained syenogranite and medium-grain (biotite) monzonitic granite (Fig. 3.27) or the Huangjian Formation volcanic strata. The intrusive contact borderline is clear. Rocks are pink-light pink, mainly composed of K-feldspar 


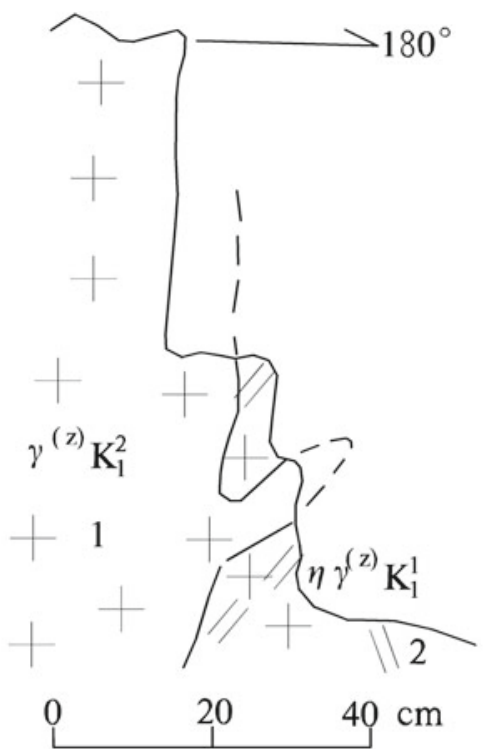

1-Fine-medium-grained syenogranite

2-Medium-grained monzonitic granite

Fig. 3.24 Fine-medium-grained granite. It intrudes in medium-grained monzonitic granite
(45-50\%), plagioclase (10-15\%), quartz (30-35\%), and a handful of biotite, with grain size of $0.5-1.5 \mathrm{~mm}$.

\section{Medium-grained syenite}

The fourth stage medium-grained syenite is pink-light pink, mainly composed of K-feldspar (80-90\%), plagioclase (5$10 \%)$, and a handful of quartz and biotite, with grain size of $1-5 \mathrm{~mm}$

\section{Wall-rock Alteration}

The Wushanguan pluton was intruded mainly along the contact zone between the Early Cretaceous Huangjian Formation volcanic rocks and the Early Paleozoic sedimentary rocks. The Huangjian Formation volcanic strata are main wall rocks, which suffered strong silicification. In the eastern part of the pluton locally distributed the Cambrian strata. The xenolith from the carbonatite and siliceous mudstone of the Yangliugang, the Xiyangshan, and the Yinzhubu Formations, occurred in the northern part of the pluton. These xenoliths underwant strong skarnization and silicification,

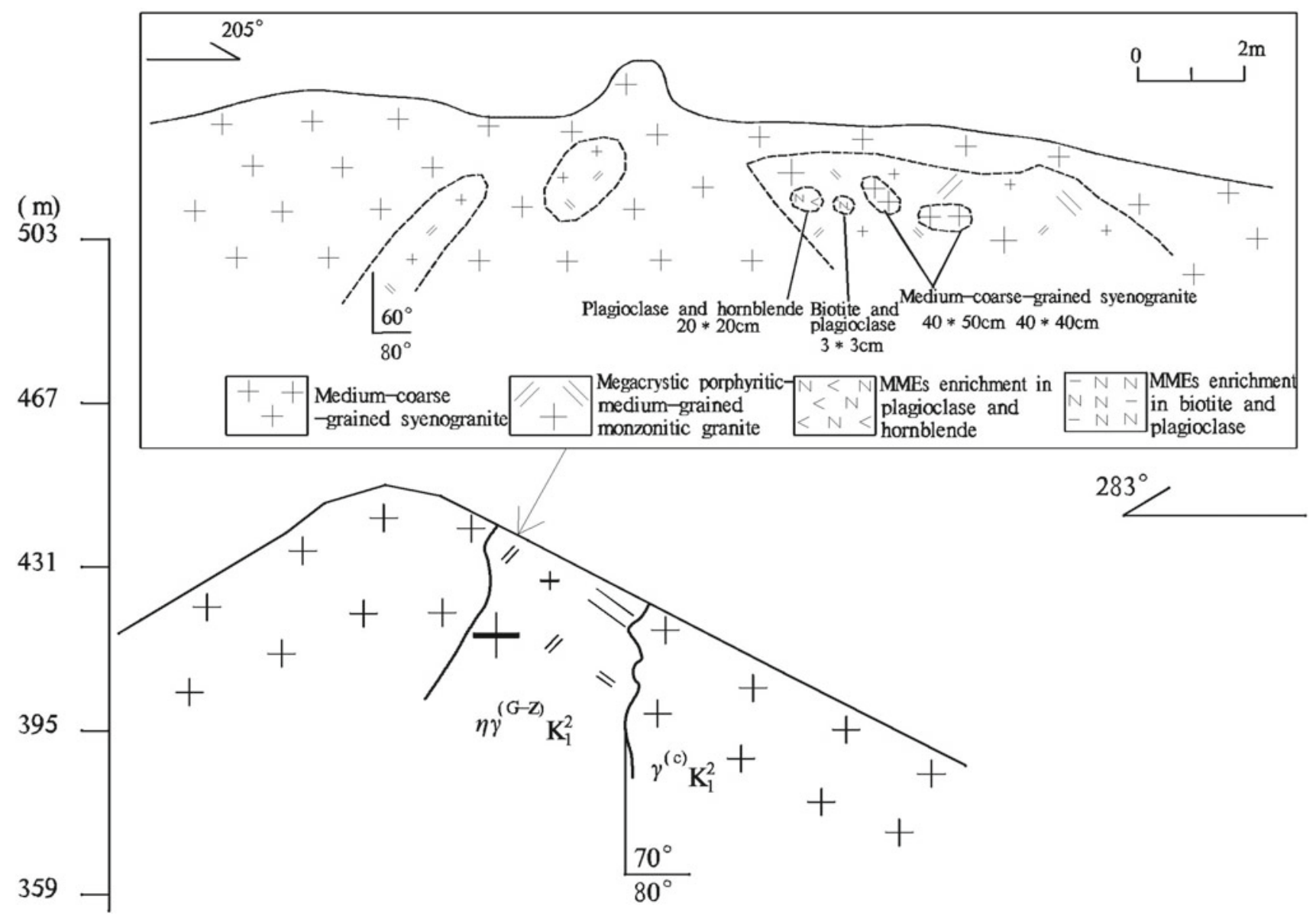

Fig. 3.25 Sketch showing the internal features of megacrystic porphyritic-medium-grained monzonitic granite and intrusive medium-coarse-grained granite contact relationship of the Wushanguan pluton 
(a)

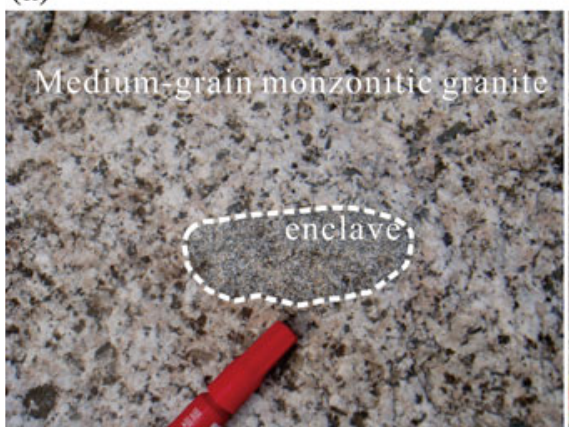

(d)

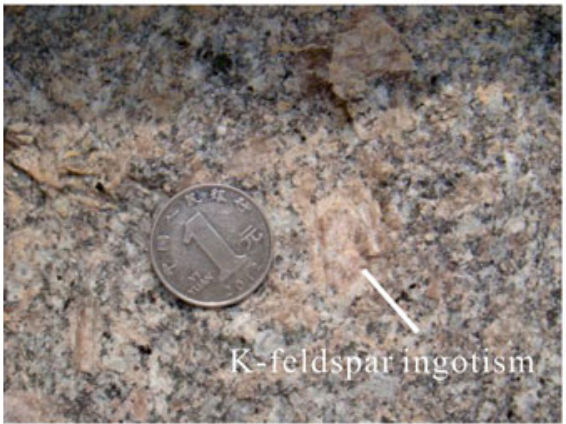

(b)

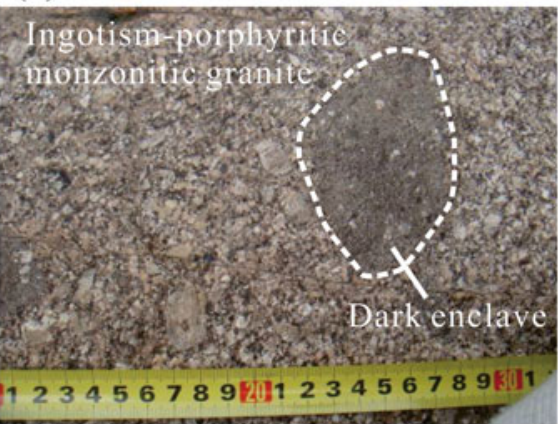

(e)

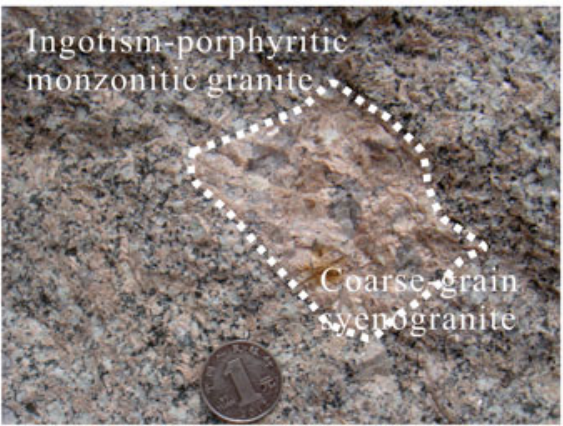

(c)

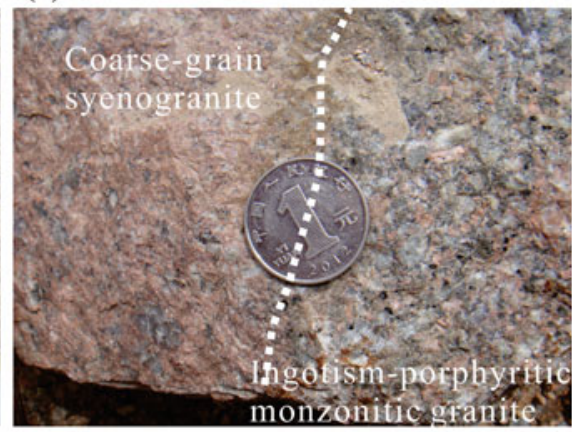

(f)

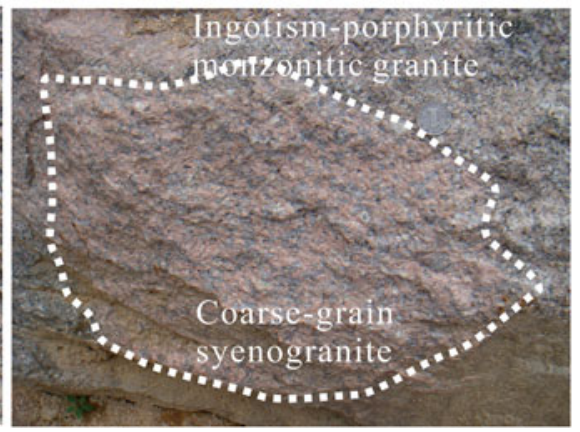

Fig. 3.26 Contact relationship between medium-coarse-grained syenogranite and megacrystic porphyritic monzonitic granite in the Wushanguan pluton. a MMEs (dark, biotite, and plagioclase bearing) developed in medium-grained monzonitic granite; b MMEs developed in megacrystic porphyritic monzonitic granite; $\mathbf{c}$ contact borderline of megacrystic porphyritic monzonitic granite and coarse-grained syenogranite; d K-feldspar phenocryst in megacrystic porphyritic monzonitic granite; $\mathbf{e}$ and $\mathbf{f}$ coarse-grained syenogranite wrapped in megacrystic porphyritic monzonitic granite (a)

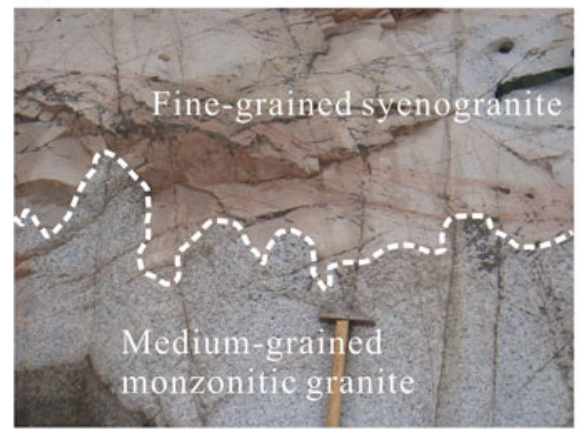

(b)

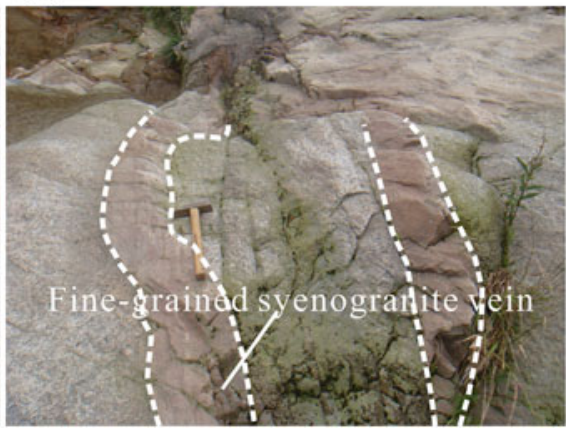

(c)

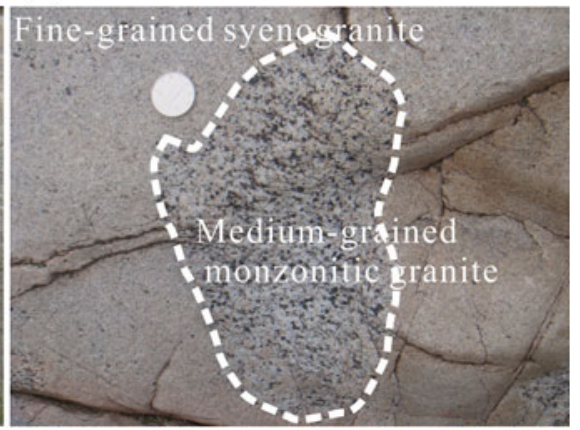

Fig. 3.27 Contact relationship of fine-grained syenogranite intrusion in medium-grained monzonitic granite at Zhaojiatang in the Wushanguan pluton. a fine-grained syenogranite intruded in early stage medium-grained monzonitic granite, with clear intrusion border line; b fine-grained syenogranite at the margin intruded as vein shape in early medium-grained monzonitic granite; c the early stage medium-grained monzonitic granite cognate xenolith in fine-grained syenogranite and even formed skarn-type $\mathrm{Fe}-\mathrm{Pb}-\mathrm{Zn}$ polymetallic ore (mineralized) bodies. The Majiatang area, in the central part of the pluton, the xenolith of the tufaceous siltstone of the Nanhuaian Xiuning Formation is seen in the contact zone between the medium-grained monzonitic granite and the medium-coarse-grained monzonitic granite, with the size of $1.5 \times 1 \mathrm{~km}^{2}$, where the rocks developed strip-like strong hornfelsic alteration.

\section{Geochemical Features}

In the Wushangguan composite pluton, the medium-grained monzonitic granite, the medium-coarse and medium-grained and the fine-grained syenogranite are high in $\mathrm{SiO}_{2}$ content (66.75-67.37\%, 75.29-76.00\%), enriched in alkali $\left(\mathrm{K}_{2} \mathrm{O}+\right.$ $\mathrm{Na}_{2} \mathrm{O}=7.49-7.62 \%, 8.20-9.14 \%$ ), high in $\mathrm{K}_{2} \mathrm{O} / \mathrm{Na}_{2} \mathrm{O}$ ratio $(1.01-1.09,1.16-1.33)$; $\mathrm{MgO}$ is $1.37 \%-1.74 \%$ and $0.10 \%-$ 
Fig. $3.28 \mathrm{~A} / \mathrm{CNK}-\mathrm{A} / \mathrm{NK}$

diagram (a) and $\mathrm{SiO}_{2}-\mathrm{K}_{2} \mathrm{O}$ diagram (b) for the Wushanguan pluton (legends are shown in Fig. 3.29) (a)

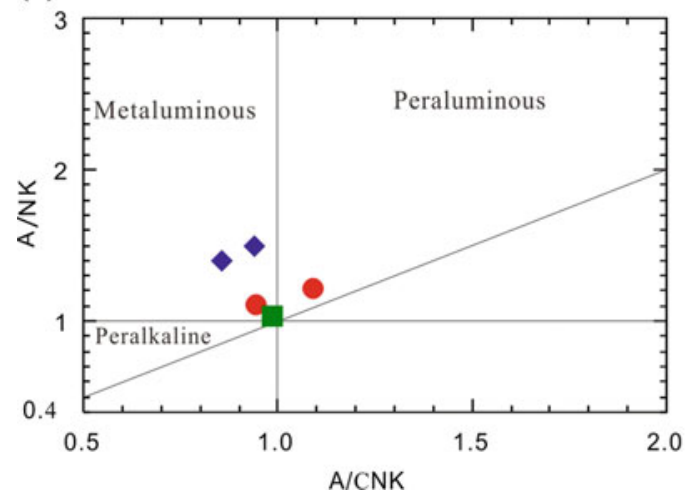

(b)

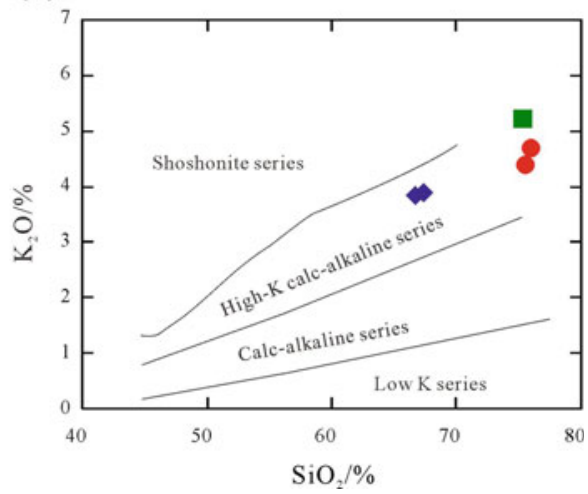

$0.28 \% . \mathrm{P}_{2} \mathrm{O}_{5}$ is $0.16 \%-0.17 \%$ and $0.01 \%-0.03 \%$, and $\mathrm{TiO}_{2}$ is $0.46 \%-0.53 \%$ and $0.07 \%-0.17 \%$, respectively. A/CNK is $0.85-0.94$ and $0.94-1.09$, respectively. The medium-grained monzonitic granite is metaluminous, and medium-coarse and medium-grained and fine-grained syenogranite is metalumonious-peraluminous. Rittmann Index $(\sigma)$ is $2.44-2.30$ and 2.07-2.59, respectively, and the two types of the rocks are high $\mathrm{K}$ calc-alkaline (Fig. 3.28).

The medium-grained monzonitic granite is low in $\sum \mathrm{REE}$ content $\left(154.36 \times 10^{-6}-170.84 \times 10^{-6}\right)$, LREE and HREE differentiated rather clear, LREE/HREE is 9.26-9.49. $\delta \mathrm{Eu}$ is 0.66-0.75, showing weak negative $\mathrm{Eu}$ anomaly. The chondrite-normalized REE patterns show the feature of weakly dipping rightward; enrichment in $\mathrm{K}, \mathrm{Rb}, \mathrm{Th}$, and $\mathrm{U}$, weakly depleted in LILE such as $\mathrm{Ba}, \mathrm{Sr}$, and P; weakly depleted in HFSE such as $\mathrm{Ti}, \mathrm{Nb}$, and $\mathrm{Ta}$ (Fig. 3.29); $\left({ }^{86} \mathrm{Sr} /{ }^{87} \mathrm{Sr}\right)_{i}$ is $0.70689, \varepsilon \mathrm{Nd}(t)$ is -4.46 , and the $\mathrm{T}_{\mathrm{DM} 2}=$ $1.29 \mathrm{Ga}$. The medium-coarse and medium-grained, fine-grained syenogranite is high in $\sum \mathrm{REE}$ content $\left(141.35 \times 10^{-6}-252.09 \times 10^{-6}\right)$, and LREE and HREE differentiated rather weakly, LREE/HREE $=4.56-9.01 . \delta \mathrm{Eu}$ ranges in the range of $0.03-0.57$, showing strong negative $\mathrm{Eu}$ anomaly. The chondrite-normalized REE patterns show the feature of weakly dipping rightward or "V" shape; enrichment in $\mathrm{K}, \mathrm{Rb}$, Th, and $\mathrm{U}$, weakly depleted in LILE such as $\mathrm{Ba}$ and $\mathrm{Sr}$; in terms of HFSE, weakly depleted in $\mathrm{Nb}$ and $\mathrm{Ta}$, etc., and strongly depleted in $\mathrm{P}$ and $\mathrm{Ti}$, etc.

\section{Isotope geochronology}

For the medium-grained monzonitic granite (D0029), the medium-grained syenogranite (D0021), the medium-coarse-grained syenogranite (D0022), and the fine-grained syenogranite (D0026), zircon is mostly in long and short strips, and less in grained, about $100-250 \mu \mathrm{m}$ in length, the length-width ratio is mostly $2: 1-3: 1$, less $1: 1$. Zircon can be seen magmatic oscillatory zoning (Fig. 3.30). Zircon's U content is $80 \times 10^{-6}-655 \times 10^{-6}, \quad 98 \times 10^{-6}-1241 \times 10^{-6}$, $28 \times 10^{-6}-6659 \times 10^{-6}$, and $571 \times 10^{-6}-1825 \times 10^{-6}$, respectively, Th content is $50 \times 10^{-6}-1003 \times 10^{-6}$, $111 \times 10^{-6}-1623 \times 10^{-6}, \quad 20 \times 10^{-6}-3987 \times 10^{-6}$, and $289 \times 10^{-6}-1524 \times 10^{-6}$, respectively, and $\mathrm{Th} / \mathrm{U}$ ratio is $0.61-$ $1.58,0.69-1.48,0.39-1.50$, and $0.43-0.86$, respectively, a typical feature of magmatism origin. Sample points tested are mostly projected on or near the concordant curve, ${ }^{206} \mathrm{~Pb} /{ }^{238} \mathrm{U}$ weighted mean age is $136.3 \pm 1.2 \mathrm{Ma}(\mathrm{MSWD}=1.6), 133.9 \pm 1.6 \mathrm{Ma}$
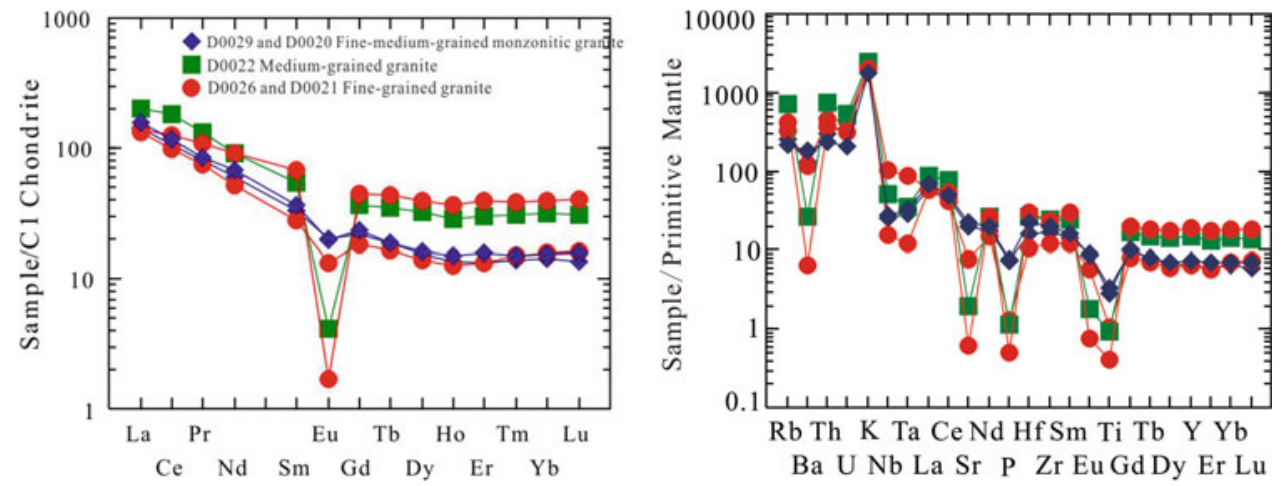

Fig. 3.29 REE chondrite-normalized distribution mode and primitive mantle-normalized trace element spider diagram for Wushanguan composite pluton (the normalized values of chondrite and primitive mantle come from Sun and McDonough 1989) 


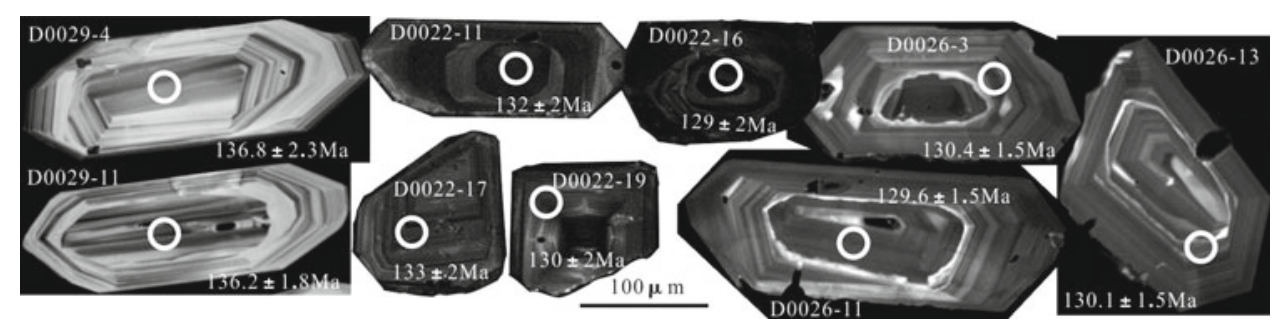

Fig. 3.30 Main Zircon CL images, dating location, and ages of the rocks in the Wushanguan composite pluton

$(\mathrm{MSWD}=0.88), \quad 131.1 \pm 1.5 \mathrm{Ma} \quad(\mathrm{MSWD}=0.88), \quad$ and $128.1 \pm 0.82 \mathrm{Ma} \quad$ (MSWD = 1.5), respectively (Fig. 3.31), representing the crystallization age of the Wushanguan composite pluton, the early stage is medium-grained monzonitic granite $(136.3 \mathrm{Ma})$, the middle stage is medium-coarsemedium-grained syenogranite (133.9-131.1 Ma) and the later stage is fine-grained syenogranite (128.1 Ma).

\subsubsection{Tonglizhuan Composite Pluton}

\section{Geological Features}

The Tonglizhuang composite pluton, of which the outcropping is small in the survey area, is located in the southeastern corner of the Hanggai Mapsheet. The pluton is nearly EW strike, distributed at the contact zone between the CambrianOrdovician siliceous rock, siltstone, carbonatite, and the Cretaceous volcanic tuff (Fig. 3.32), and intruded along the Luocun anticline axial, about $5 \mathrm{~km}$ long from east to west and $0.5-2 \mathrm{~km}$ wide from south to north. The pluton is mainly composed of the early stage medium-grain monzonitic granite inside, the middle stage fine-grain syenogranite at the northern margin, and the later stage medium-grain quartz orthophyre at the southern part and eastern margin. The granite, apilite, and sillite veins occurred in NW, NE or nearly SN strike inside the pluton.

\section{Petrological Features}

Medium-grained monzonitic granite is gray-light gray, medium-fine-grained and coarse-medium-grained subhedral granular texture, mainly composed of plagioclase (35-45\%), K-feldspar (25-35\%), quartz (20-30\%), biotite (5-6\%), and hornblende $(<5 \%)$, with the grain size of $0.2-3 \mathrm{~mm}$ and bigger than $5 \mathrm{~mm}$ for a handful. Plagioclase is subhedral plate or column, slight sericitization on the surface, and growth Na-feldspar bicrystal and zoning structure; K-feldspar is mostly striped feldspar, irregular plate, with plagioclase replacement and inclusion structure; quartz, is anhedral granular, unevenly distributed among feldspar grains; biotite is dark brown, platy or laminated, partly alterated into chlorite along joints; hornblende is light green and long column (Fig. 3.33a, d, e).

Fine-grained syenogranite is pink-light pink, fine-grained texture, is mainly composed of K-feldspar (40-50\%), plagioclase (20-25\%), quartz (20-30\%), and a handful of biotite $(5 \%)$, in the grain size of $0.2-1 \mathrm{~mm}$. K-feldspar is mainly orthoclase, wide plate, growth Carlsbad bicrystal; plagioclase is hypidiomorphic wide plate and plate-column, growth Na-feldspar bicrystal; quartz is hexagonal bipyramid and in form of fine granular aggregation; biotite is reddish brown and plate or laminated, and its margin is often surrounded by fine biotite aggregation and irony points (Fig. 3.33b, f).

Medium-grained quartz orthophyre is pink-light pink and medium-grained porphyaceous texture. Phenocryst is mainly composed of K-feldspar (25-30\%), plagioclase (5-10\%), and a handful of quartz and biotite, in the grain size of 1$5 \mathrm{~mm}$; while matrix is micro-grained texture, and mainly composed of K-feldspar (40-45\%), quartz (5-10\%), and a handful of plagioclase (5-10\%) as well as accessory minerals such as undeterminated metallic minerals, apatite, and zircon, with the grain size of $0.05-0.1 \mathrm{~mm}$; K-feldspar is mainly orthoclase while plagioclase is mainly oligoclase (Fig. 3.33c).

\section{Wall-rock Alteration}

Medium-grained monzonitic granite and fine-grained syenogranite suffered from strong alteration, and its inside shows albitazation, greisenization, and chloritization and wall rocks show hornfelsic, skarnization, silicification, pyritization, and marbleization. The medium-grained quartz orthophyre suffered from weak alteration and show slight albitazation.

\section{Geochemical Features}

The early medium-grained monzonitic granite is high in $\mathrm{SiO}_{2}$ content (70.61\%), enrichment in alkali (Alk $=\mathrm{K}_{2} \mathrm{O}+$ $\mathrm{Na}_{2} \mathrm{O}, 7.75 \%$ ), high in $\mathrm{K}_{2} \mathrm{O} / \mathrm{Na}_{2} \mathrm{O}$ ratio (1.27); and low in content of $\mathrm{MgO}(0.98 \%), \mathrm{P}_{2} \mathrm{O}_{5}(0.10 \%)$, and $\mathrm{TiO}_{2}(0.32 \%)$. 

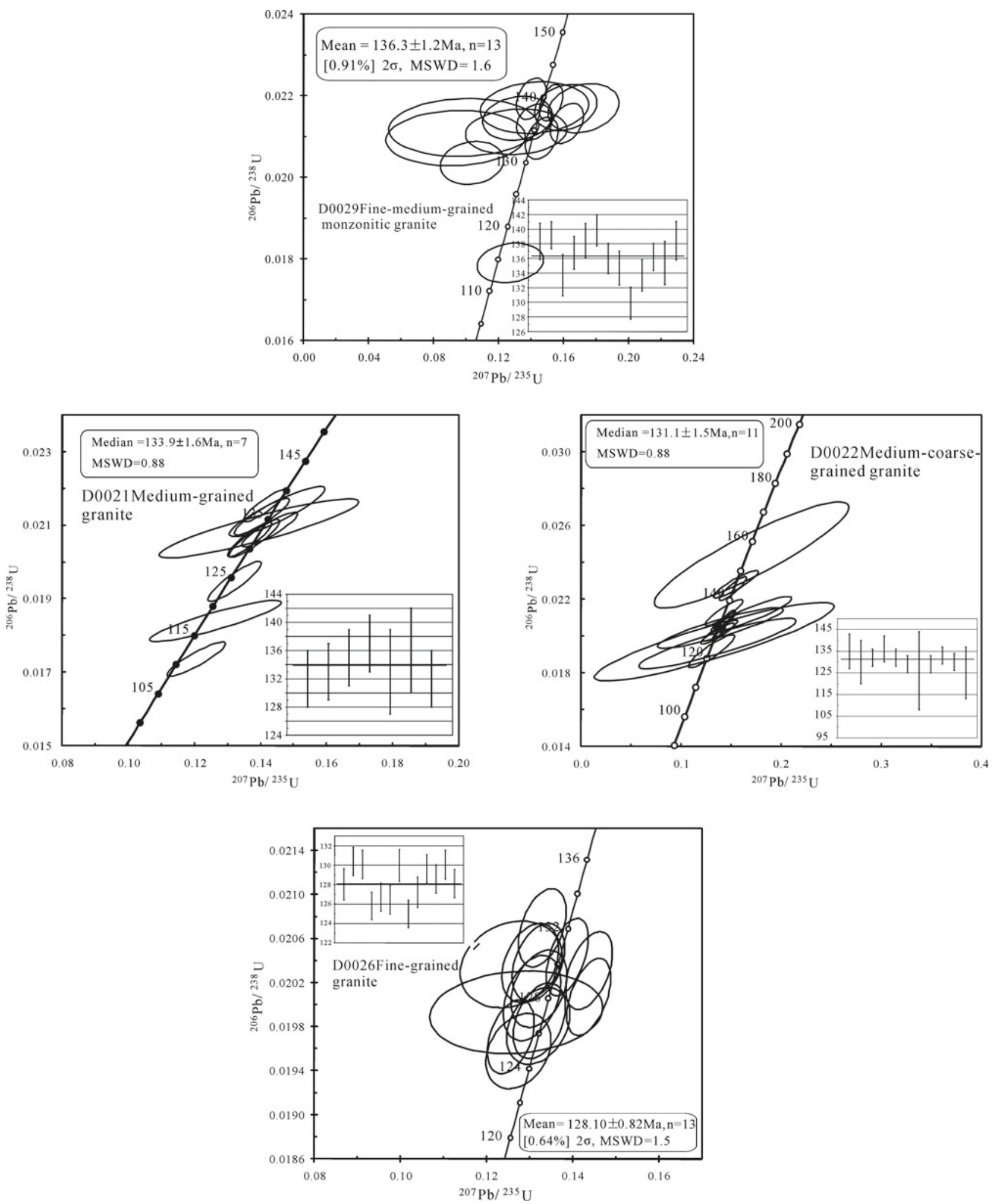

Fig. 3.31 Zircon U-Pb concordant curve of main lithologies of the Wushanguan composite pluton 


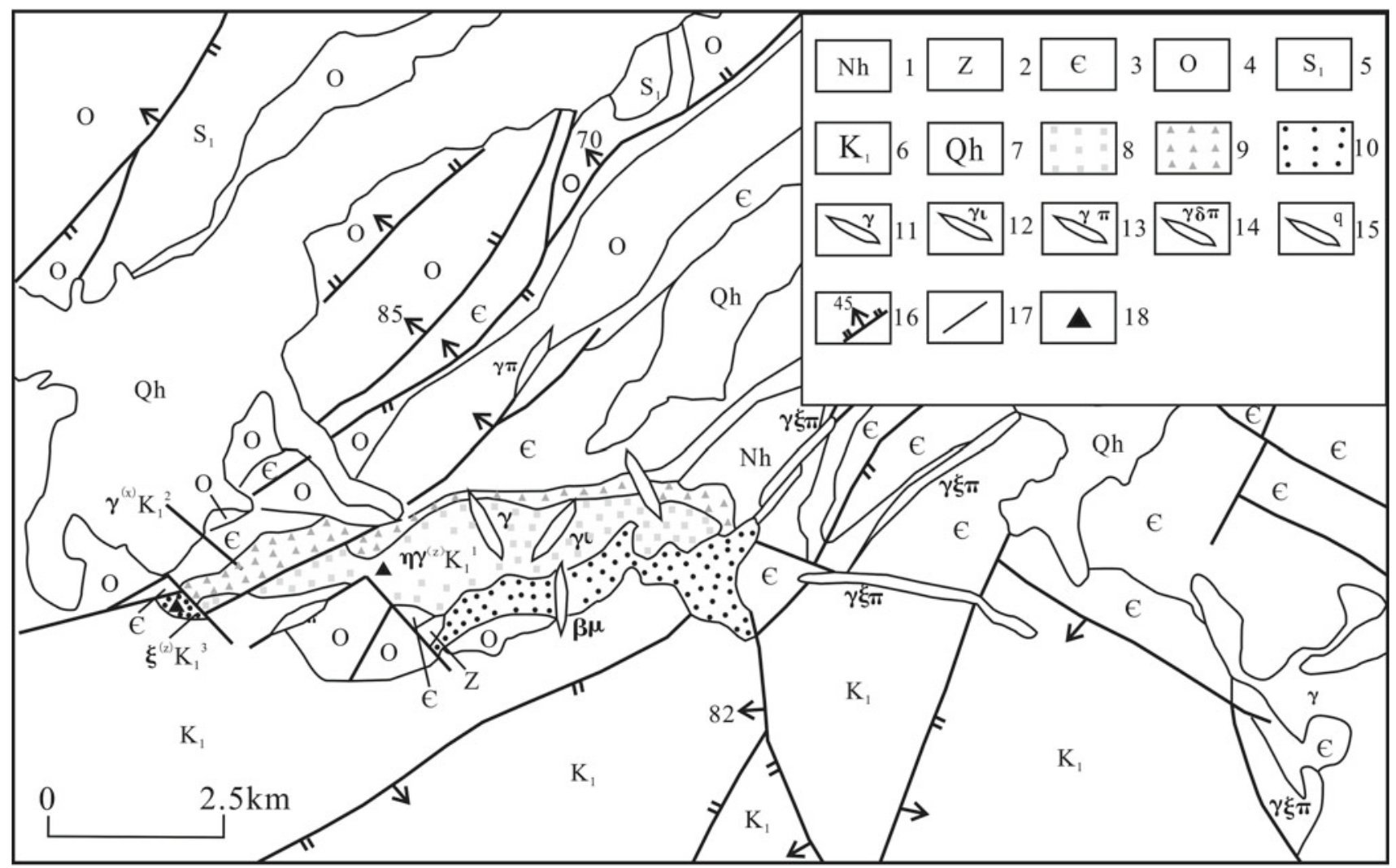

Fig. 3.32 Regional geological sketch of the Tonglizhuang composite pluton (based on the 1:200,000 Lin'an Mapsheet). 1. Nahuaian; 2. Sinian; 3. Cambiran; 4. Ordovician; 5. the lower Silurian; 6. the lower Cretaceous; 7. Quaternary; 8. medium-grained monzonitic granite; 9. fine-grained syenogranite; 10. medium-grained quartz orthophyre; 11. fine-grained granitic vein; 12 . granitic aplite vein; 13. granitic porphyry vein; 14. granodiorite-porphyry vein; 15 . quartz vein; 16 . normal fault; 17. geological boundary; 18. sampling location
$\mathrm{A} / \mathrm{CNK}$ is 1.00 , Rittmann Index $(\sigma)$ is 2.18 , shown weakly peraluminous and high $\mathrm{K}$ calc-alkaline features (Fig. 3.34).

The later medium-grained quartz orthophyre is low in $\mathrm{SiO}_{2}$ content $(66.25 \%)$, enrichment in alkali (Alk $=\mathrm{K}_{2} \mathrm{O}+$ $\mathrm{Na}_{2} \mathrm{O}, 10.02 \%$ ), high in $\mathrm{K}_{2} \mathrm{O} / \mathrm{Na}_{2} \mathrm{O}$ ratio (1.66); low in content of $\mathrm{MgO}(0.67 \%), \mathrm{P}_{2} \mathrm{O}_{5}(0.10 \%)$, and $\mathrm{TiO}_{2}(0.37 \%)$. $\mathrm{A} / \mathrm{CNK}$ is 0.94 , Rittmann Index $(\sigma)$ is 4.32 and is metaluminous and shoshonite features.

Both are low in $\sum$ REE content $\left(127.02 \times 10^{-6}\right.$ $\left.183.02 \times 10^{-6}\right)$, LREE and HREE differentiated rather clear, LREE/HREE = 11.71-9.12, $\mathrm{La}_{\mathrm{N}} / \mathrm{Yb}_{\mathrm{N}}=15.67-9.58$, $\delta \mathrm{Eu}=0.72-0.79$, showing weak negative Eu anomaly, the chondrite-normalized REE patterns show the feature of weakly dipping rightward; enrichment in $\mathrm{K}, \mathrm{Rb}$, Th, and $\mathrm{U}$, weakly depleted in LILE such as Ba and Sr; weakly depleted in HFSE such as Nb, Ta, P, and Ti. Both have similar REE and trace elements features, indicating that both may have the same magma source.

\section{Isotope geochronology}

Zircons from the medium-grained monzonitic granite and medium-grained quartz orthophyre are mostly long and short strips, a small amount is granular, about 100-300 $\mu \mathrm{m}$ long, the length-width ratio is mostly $2: 1-1: 1$, less $3: 1$. Zircons contain clear magmatic oscillatory zoning. Zircons have U content of $(383-1635) \times 10^{-6}$ and $(80-1053) \times 10^{-6}$, respectively, Th content $(329-1828) \times 10^{-6}$ and (76$730) \times 10^{-6}$, respectively, and $\mathrm{Th} / \mathrm{U}$ ratio $0.70-1.33$ and 0.61-1.24, respectively, indicating typical magmatic origin zircon. Sample points tested are mostly projected on or near the concordant curve, and ${ }^{206} \mathrm{~Pb} /{ }^{238} \mathrm{U}$ weighted mean age is $142.3 \pm 1.4 \mathrm{Ma} \quad(\mathrm{MSWD}=1.5)$ and $125.3 \pm 1.6 \mathrm{Ma}$ (MSWD = 1.4), respectively (Fig. 3.35). For the medium-grained monzonitic granite's sample points D0032-16 and D0032-17, the ${ }^{206} \mathrm{~Pb} /{ }^{238} \mathrm{U}$ ages are $758 \mathrm{Ma}$ and $518 \mathrm{Ma}$, respectively, which indicate they are probably inherited zircons. The ${ }^{206} \mathrm{~Pb} /{ }^{238} \mathrm{U}$ ages of a few sample 

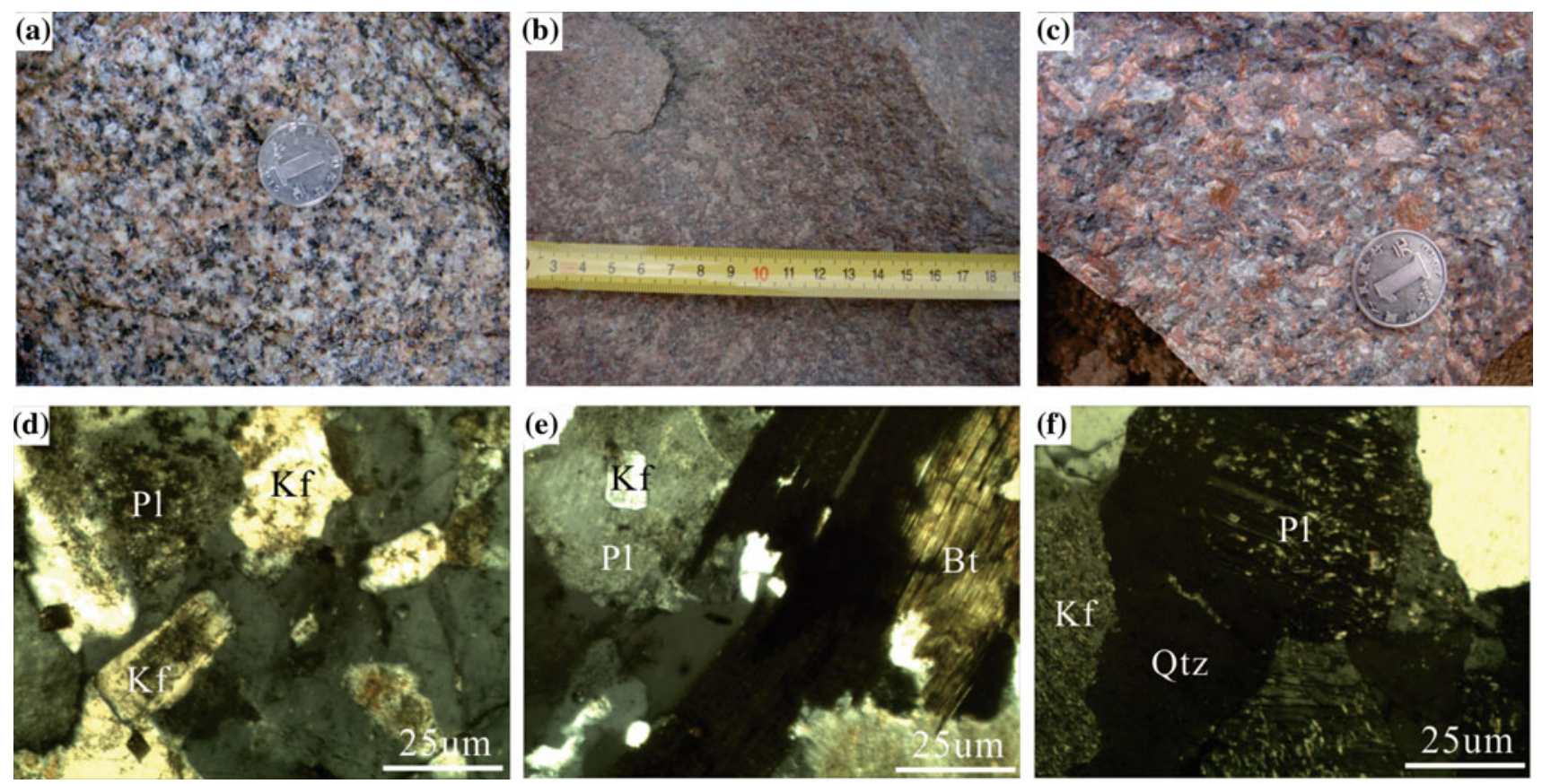

Fig. 3.33 Outcrop and micrograph images showing the lithological features in the Tonglizhuang pluton. a medium-grained monzonitic granite; b fine-grained syenogranite; c medium-grained quartz orthophyre; d K-feldspar (Kf) and plagioclase $(\mathrm{Pl})$ in medium-grained

points (D0005-07, D0005-08, D0005-09, D0005-11) from the medium-grained quartz orthophyre are $148-137 \mathrm{Ma}$, possibly suggesting inherited zircons from the early stage monzonitic granite.

The Paleozoic strata and the volcanic rocks in Mount Tianmu are intrusive contact between the two sides of the Tonglizhuang composite pluton. The zircon $\mathrm{U}-\mathrm{Pb}$ dating results indicated that crystallization age of the early medium-grained monzonitic granite is $142.3 \pm 1.4 \mathrm{Ma}$. By comparing the lithological types and features of intrusive rocks in the survey area, the crystallization time of the middle stage fine-grained syenogranite was close to the fine-grained syenogranite in the Ma'anshan pluton and the Xianxia pluton (129.6-128.3 Ma). The forming time of the later stage medium-grained quartz orthophyre was $125.3 \pm 1.5$ Ma. Magmatism in the early and middle stages was likely to be related to the translational extensional fractures developed in the late Yanshanian in northern Zhejiang and southern Anhui, while the late-stage magmatism was likely to be related to regional volcanic eruption activities. monzonitic granite; e plagioclase ( $\mathrm{Pl}$ ) containing K-feldspar (Kf) core growth in medium-grained monzonitic granite; f plagioclase ( $\mathrm{Pl})$, $\mathrm{K}$-feldspar (Kf), and quartz (Qtz) in fine-grained syenogranite

\subsubsection{Zhinanshan-Dongkeng Volcanic-Intrusive Complexes}

\section{Geological Features}

The Zhinanshan volcanic-intrusive complex, located in the central-south of the Chuancun Mapsheet, is NW-strike, about $1 \mathrm{~km}$ long and $700 \mathrm{~m}$ wide, with outcrop areas of $0.7 \mathrm{~km}^{2}$. The complex intruded into the second member of the Huangjian Formation rhyolitic tuff lava, mainly consisting of fine-medium-grained quartz diorite. An early stage andesite pluton of $0.2 \mathrm{~km}^{2}$ is presented in the east of the quartz diorite, and quartz diorite cemented andesite agglomerate breccia is visible at the margin of the intrusive contact zone (Fig. 3.36).

Dongkeng volcanic-intrusive complex is situated in the central of the Chuancun Mapsheet, about $3 \mathrm{~km}$ from the Zhinanshan volcanic-intrusive complex, nearly EW strike, ellipse, $2 \mathrm{~km}$ long from east to west and $1.5 \mathrm{~km}$ long from south to north, with outcrop areas of $1.2 \mathrm{~km}^{2}$. The complex intruded at the border of the second member of the 

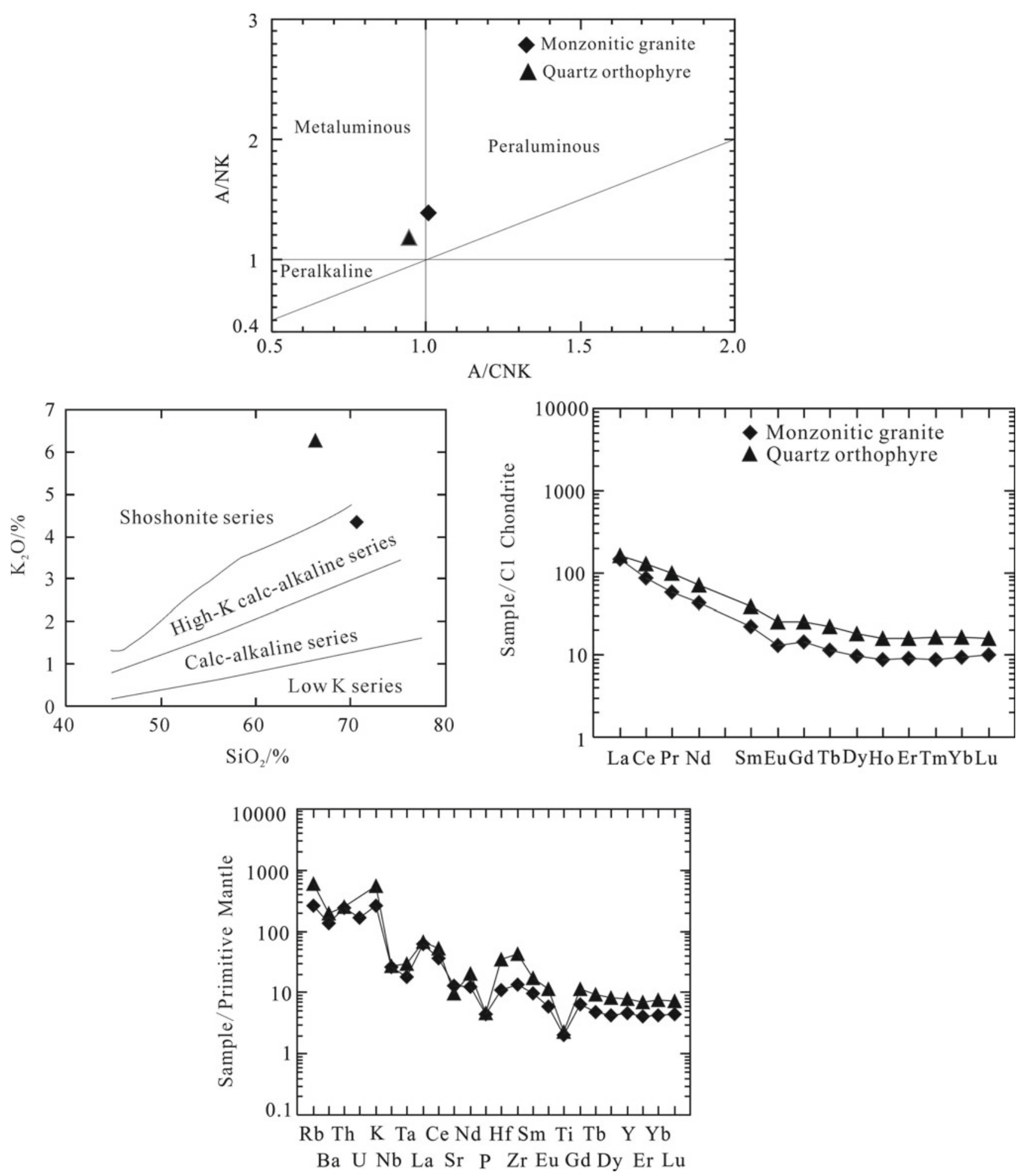

Fig. 3.34 REE chondrite-normalized distribution mode and primitive mantle-normalized trace element spider diagram for Tonglizhuang composite pluton (the normalized values about chondrite and primitive mantle come from Sun and McDonough 1989) 

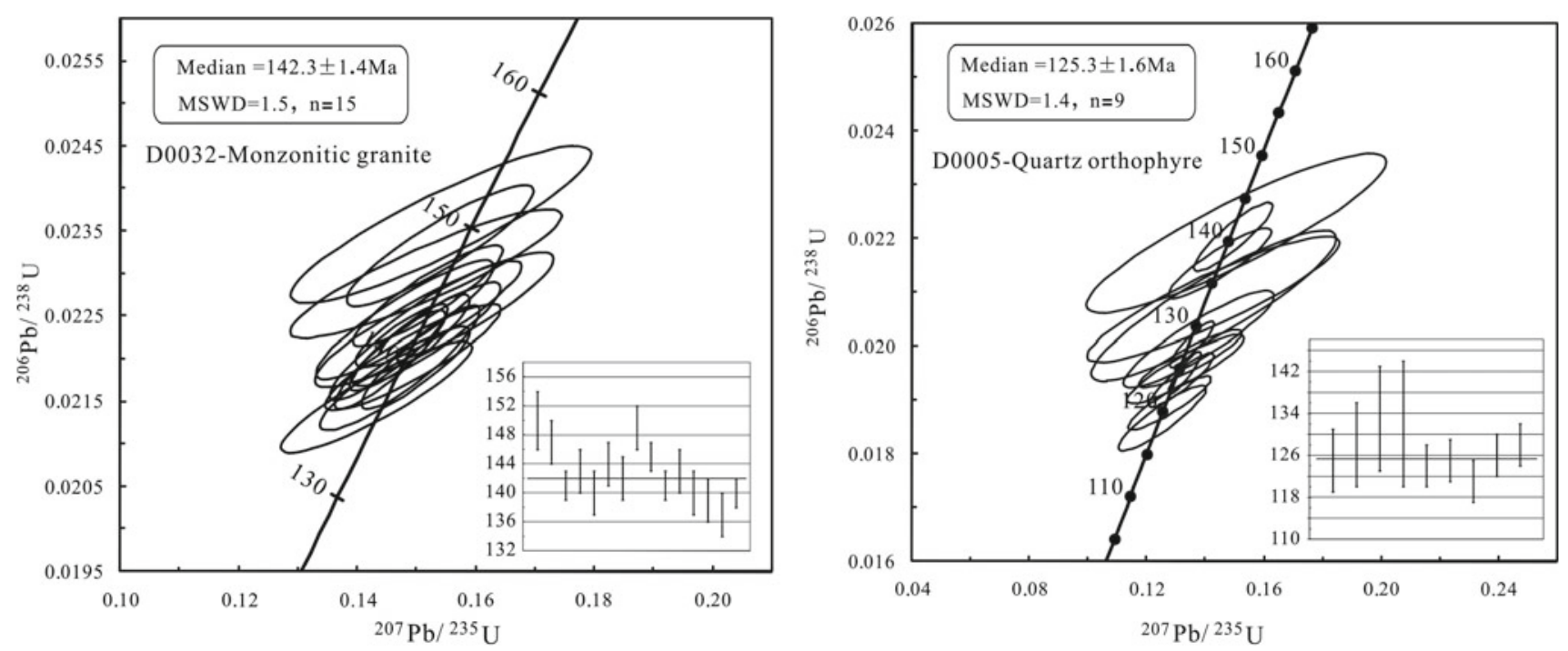

Fig. 3.35 Zircon U-Pb concordant diagrams for the Tonglizhuang composite pluton

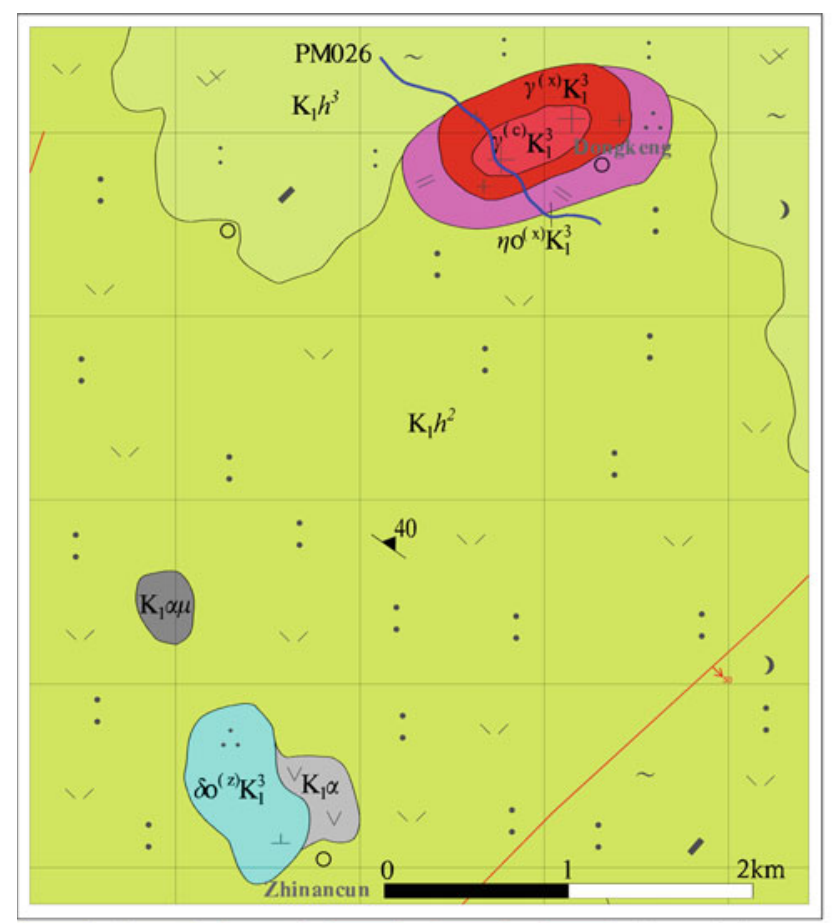

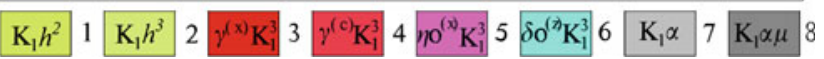

Fig. 3.36 Sketch geological map of the Zhinanshan-Dongkeng volcanic-intrusive complex. 1. the second member of the Huangian Formation; 2. the third member of the Huangjian Formation; 3. fine-grained granite; 4. coarse-grained granite; 5. fine-grained quartz monzonite; 6. medium-grained quartz diorite; 7 . andesite; 8 . andesitic porphyrite

Huangjian Formation rhyolitic tuff lava and the third member of the Huangjian Formation rhyodacitic gravel-bearing vitroclastic ignimbrite and is composed of fine-grained quartz monzonite in the periphery, and medium-coarse-grained syenogranite and fine-grained syenogranite (porphyry) inside (Fig. 3.37). Grain sizes of the minerals in the Dongkeng complex were gradually larger from the edge to the center.

The south side of the Zhinanshan-Dongkeng complexes is widely in intrusive contact with the second member of the Huangjian Formation $\left(\mathrm{K}_{1} h^{2}\right)$ rhyolitic tuff lava, while the north side is in intrusive contact with the third member of the Huangjian Formation $\left(\mathrm{K}_{1} h^{3}\right)$ rhyodacitic gravel-bearing vitroclastic ignimbrite. Quartz diorite, granitic porphyry, felsite, and andesite veins are presented inside and outside of the contact zone between the complexes and the secondthird member of the Huangjian Formation.

\section{Petrological Features}

Fine-medium-grained quartz diorite in the Zhinanshan complex is light gray, fine-medium-granular texture, mainly composed of quartz (15-22\%), K-Na-feldspar (5\%), plagioclase $(50 \%)$, and hornblende $(20 \%)$. The grain size is generally $0.4-1 \mathrm{~mm}$ but up to $1.5-3 \mathrm{~mm}$ for a handful, and K-feldspar and hornblende phenocryst locally seen with grain size up to 5-6 mm (Fig. 3.38). Quartz is granular, distributed pretty evenly. Plagioclase is plate-column-like, mostly weathered, mainly andesine-oligoclase based on the refractive index. Hornblende is column-like, distributed rather evenly. Rocks at the margin of the complex are cemented with early stage andesite agglomerate breccia, which content is $25-70 \%$. The agglomerate is angularsubangular, and varies in sizes between 6 and $25 \mathrm{~mm}$.

Based on the field contact relationship, from early to late stage, the Dongkeng volcanic-intrusive complex is medium-fine-grained (porphyritic) quartz monzonite $\rightarrow$ fine-grained syenogranite (porphyry) $\rightarrow$ medium-coarsegrained syenogranite. 


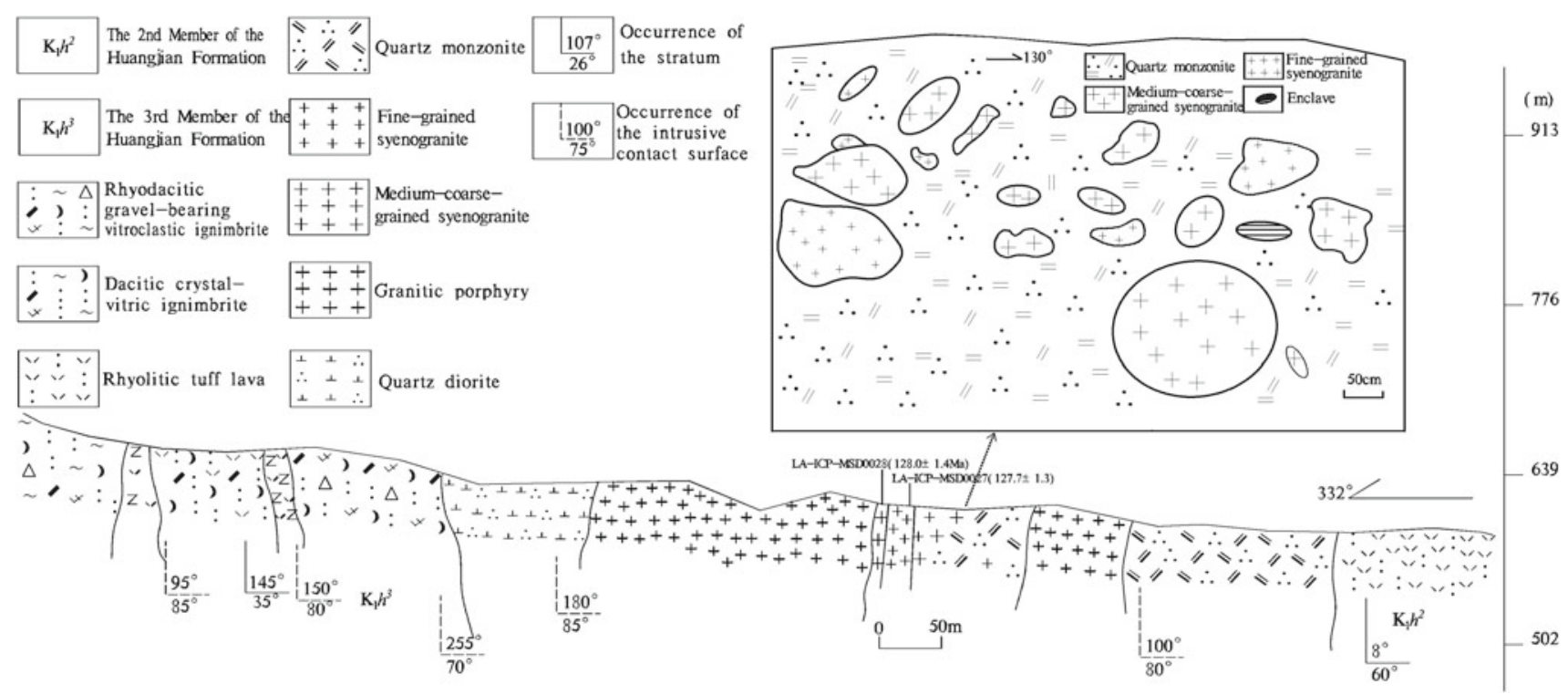

Fig. 3.37 Geological section map of the Dongkeng volcanic-intrusive complex

(a)

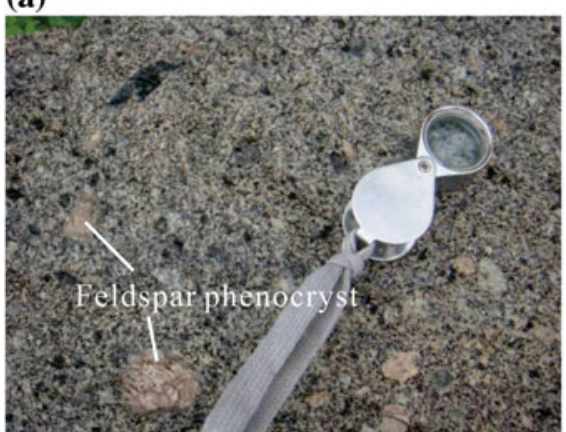

(d)

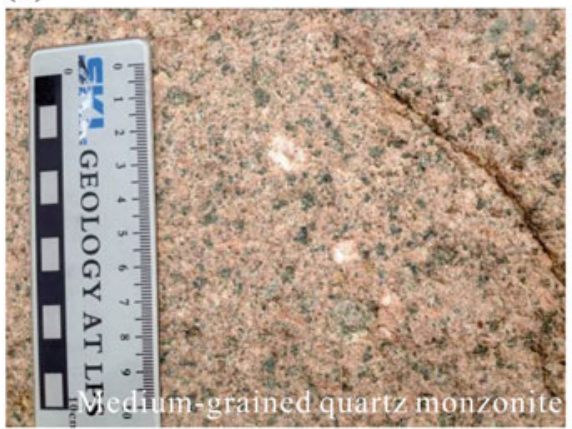

(b)

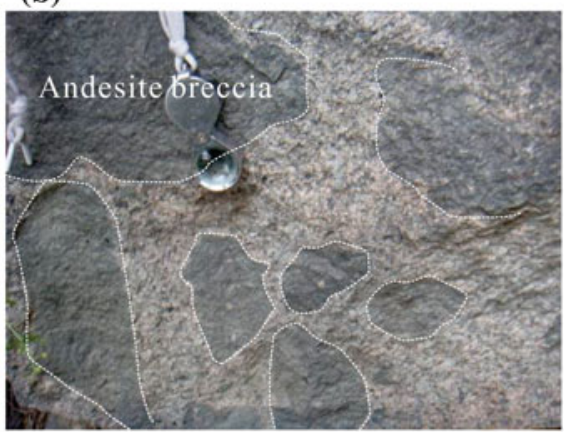

(e)

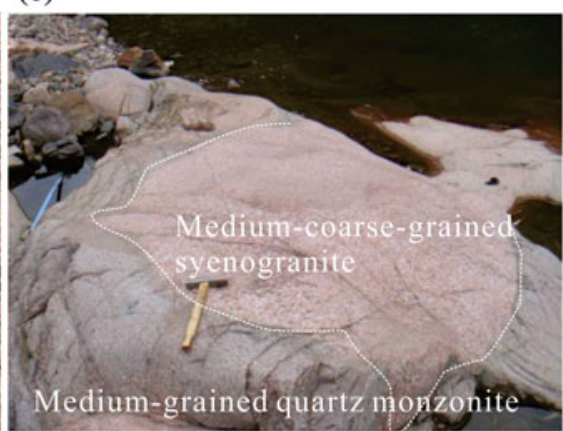

(c)

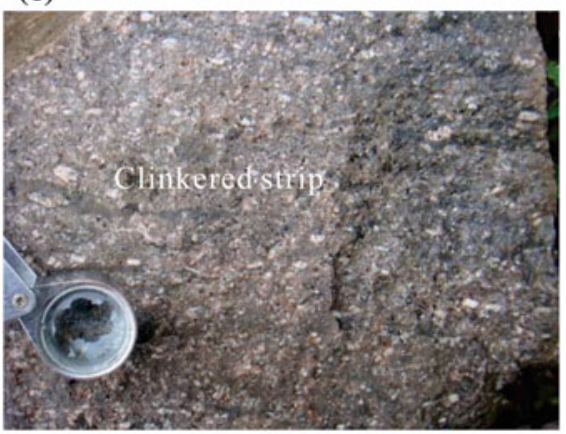

(f)

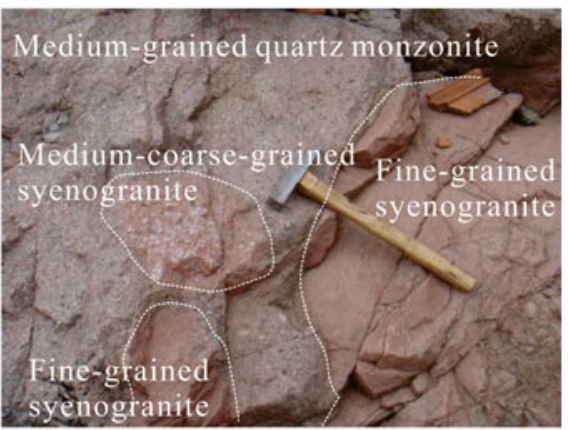

Fig. 3.38 Outcrop images showing the contact relationship between the main rock types in the Zhinanshan-Dongkeng volcanic-intrusive complexes. a Quartz diorite (porphyry) in the Zhinanshan complex; b quartz diorite(porphyry)-cemented andesite breccia in the Zhinanshan complex; c clinkdered strip occurred in rhyolitic tuff lava, which is the wall rocks of quartz diorite (porphyry) in the Zhinanshan complex; d the early stage medium-grained quartz monzonite in the Dongkeng complex; e the lump medium-coarse-grained syenogranite intruded in the early stage medium-grained quartz monzonite; f medium-coarse-grained, fine-grained lump syenogranite intruded in the early stage medium-grained quartz monzonite
Medium-fine-grained (porphyritic) quartz monzonite in the Dongkeng complex is light gray and medium-fine-grained (porphyritic) texture. Phenocryst contains plagioclase (20\%),
K-Na-feldspar (8\%), hornblende (4\%), and very little quartz. The grain size of the phenocryst is $1-3 \mathrm{~mm}$, but a small amount up to 3-4 mm; and locally K-feldspar is $5-10 \mathrm{~mm}$ in size; 
plagioclase is $1-4 \mathrm{~mm}$ in size, but a small amount up to 4 $12 \mathrm{~mm}$, and epidotization occurred somewhere; hornblende is $0.5-3 \mathrm{~mm}$ in size. Matrix contains quartz (12\%), K-Na-feldspar (major), and plagioclase (minor) (55\%) in the grain size of $0.2-$ $0.5 \mathrm{~mm}$. Some gray-green ellipse-like irregular enclaves are seen in the size of $1-8 \mathrm{~cm} \times 1-8 \mathrm{~cm}$. The light pink micro-grained to fine-grained irregular rhyolitic tuff lava xenoliths are also presented, in the size of $40 \mathrm{~cm} \times 30 \mathrm{~cm}$ with no clear border. The coarse-mediumgrained syenogranite and fine-grained syenogranite (porphyry) inclusions are developed in the medium-fine-grained quartz monzonite near the central of the complex, which are irregular and varies in size about $10-150 \mathrm{~cm}$ (length) $\times 10-150 \mathrm{~cm}$ (width). Few oval fluidal structure enclave is visible, about $40 \mathrm{~cm} \times 30 \mathrm{~cm}$ in size. The border of syenogranite inclusions and quartz monzonite is irregular but clear, lack of burning-off or alteration, etc. Andesite veins, 1-2 m wide, intruded in quartz monzonite, the contact surface is irregular bending, with the occurrence of $100^{\circ} \angle 80^{\circ}$.

Fine-grained syenogranite (porphyry) is light pink, granitic (porphyritic) texture, and matrix is micro-grained texture. Phenocryst mainly quartz (16\%), K-Na-feldspar (10\%), plagioclase (2\%), and a handful of biotite, with the general size of 1-2 $\mathrm{mm}$ and very little of 2-6 mm, epidotization occurred to a handful of plagioclase, not evenly distributed. Matrix mainly contains feldspar (50\%) and quartz (20\%), about $0.1-$ $0.2 \mathrm{~mm}$ in grain sizes; quartz is granular, feldspar is plate and mainly K-Na-feldspar with a handful of plagioclase. In the fine-grained syenogranite (porphyry), light pink micro-grained to fine-grained syenite veins and light pink coarse-medium-grained granite lumps can be seen locally. Two groups of joints are seen in outcrop of the complexes, with the occurrences of $322^{\circ} \angle 50^{\circ}$ and $138^{\circ} \angle 40^{\circ}$.

Medium-coarse-grained syenogranite is light pink, medium-coarse-granular texture, mainly consisting of quartz (32\%), K-Na-feldspar (56\%), and plagioclase (12\%), with the general grain size of 3-8 $\mathrm{mm}$ or a few of $8-12 \mathrm{~mm}$. The large lump-like syenogranite intruded in fine-grained syenogranite and medium-fine-grained (porphyritic) quartz monzonite, while the lump varies in size ranging from $5-150 \mathrm{~cm} \times 5-200 \mathrm{~cm}$, with clear borderline and lack of clear burning-off alteration.

\subsection{Geochemical Features}

Quartz diorite in the Zhinanshan complex, and the medium-fine-grained quartz monzonite, the fine-grained syenogranite (porphyry), as well as the medium-coarse-grained syenogranite in the Dongkeng complex have similar geochemical features, possibly due to the differentiation evolution passes from the same magma origin.

Volcanic-intrusive rock is high in $\mathrm{SiO}_{2}$ content (58.30$75.25 \%)$, enrichment in alkali $\left(\mathrm{Alk}=\mathrm{K}_{2} \mathrm{O}+\mathrm{Na}_{2} \mathrm{O}, 7.33\right.$
8.87\%), high in $\mathrm{K}_{2} \mathrm{O} / \mathrm{Na}_{2} \mathrm{O}$ ratio (1.20-1.97), variable in $\mathrm{MgO}$ content $(0.29-3.47 \%)$, low in content of $\mathrm{P}_{2} \mathrm{O}_{5}(0.02-0.41 \%)$ and $\mathrm{TiO}_{2}(0.10-0.99 \%) ; \mathrm{A} / \mathrm{CNK}$ is $0.81-1.04$ and Rittmann Index $(\sigma)$ is $2.44-3.51$, having the features of metaluminous-weakly peraluminous and shoshonite features (Fig. 3.39).

All rocks in the Zhinanshan-Dongkeng complexes have medium $\sum$ REE content $\left(135.25 \times 10^{-6}-202.71 \times 10^{-6}\right)$, LREE and HREE differentiated rather obvious, LREE/HREE $=4.49-8.06, \quad \mathrm{La}_{\mathrm{N}} / \mathrm{Yb}_{\mathrm{N}}=3.42-9.24, \quad \delta \mathrm{Eu}=$ 0.15-0.64, having strong negative $\mathrm{Eu}$ anomalies, the chondrite-normalized REE patterns show the feature of weakly dipping rightward, enrichment in $\mathrm{K}, \mathrm{Rb}, \mathrm{Th}$, and $\mathrm{U}$, weakly depleted in LILE such as $\mathrm{Sr}$ and $\mathrm{Ba}$; depleted or weakly depleted in HFSE such as $\mathrm{Ti}, \mathrm{P}, \mathrm{Nb}$, and $\mathrm{Ta}$.

From fine-medium-grained quartz diorite $\rightarrow$ medium-finegrained quartz monzonite $\rightarrow$ fine-grained syenogranite $\rightarrow$ medium-coarse-grained syenogranite, $\mathrm{SiO}_{2}$ and $\mathrm{A} / \mathrm{CNK}$ increased gradually, and contents of $\mathrm{TiO}_{2}, \mathrm{Al}_{2} \mathrm{O}_{3}, \mathrm{MgO}$, $\mathrm{CaO}, \mathrm{P}_{2} \mathrm{O}_{5}, \mathrm{MnO}$, LREE, $\mathrm{Sr}$, and $\mathrm{Ba}$ as well as $\delta$ Eu decrease gradually. For fine-grained and medium-coarse-grained syenogranite, $\left({ }^{86} \mathrm{Sr} /{ }^{87} \mathrm{Sr}\right)_{\mathrm{i}}=0.70554-0.70636, \varepsilon \mathrm{Nd}(t)=-5.73$ to -4.19 and the $\mathrm{T}_{\mathrm{DM} 2}=1.26-1.39 \mathrm{Ga}$.

\section{Isotope geochronology}

For the fine-medium-grained quartz diorite in Zhinanshan complex, the fine-grained syenogranite and medium-coarsegrained syenogranite in Dongkeng complex, zircons are mostly in long and short strips, and a few granular. Zircons have oscillatory growth zoning. Zircons in quartz diorite are about $70-120 \mu \mathrm{m}$ long, its length-width ratio is mostly $1: 1$ and a few in 1.5:1, while in fine-grained syenogranite and medium-coarse-grained syenogranite, zircons is about 100 $300 \mu \mathrm{m}$ long, its length-width ratio is mostly $2: 1-1: 1$, and a few 3:1.

Zircons in the quartz diorite of the Zhinanshan complex, $\mathrm{U}$ content is $120 \times 10^{-6}-375 \times 10^{-6}$, Th is $118 \times 10^{-6}$ $584 \times 10^{-6}$, and $\mathrm{Th} / \mathrm{U}$ ratio is $0.81-1.66$, showing a typical feature of magma origin. Sample locations mostly are projected on or near the concordant curve, ${ }^{206} \mathrm{~Pb} /{ }^{238} \mathrm{U}$ weighted mean age is $130.5 \pm 1.7 \mathrm{Ma}(\mathrm{MSWD}=0.96)$ (Fig. 3.40), representing the crystallization age of Zhinanshan complex.

Zircons in the fine-grained syenogranite and medium-coarse-grained syenogranite of the Dongkeng complex, $\mathrm{U}$ content is $146 \times 10^{-6}-558 \times 10^{-6}$ and $85 \times 10^{-6}$ $1445 \times 10^{-6}$, respectively, Th content is $101 \times 10^{-6}$ $426 \times 10^{-6}$ and $61 \times 10^{-6}-978 \times 10^{-6}$, respectively, and $\mathrm{Th} / \mathrm{U}$ ratio is $0.70-1.11$ and $0.58-0.94$, respectively, a typical feature of magma origin. Sample locations mostly are projected on or near the concordant curve, and ${ }^{206} \mathrm{~Pb} /{ }^{238} \mathrm{U}$ weighted mean age is $127.6 \pm 1.2 \mathrm{Ma}(\mathrm{MSWD}=1.8)$ and $127.9 \pm 1.3 \mathrm{Ma}(\mathrm{MSWD}=1.7)$, representing the crystallization age of the Dongkeng complex. 

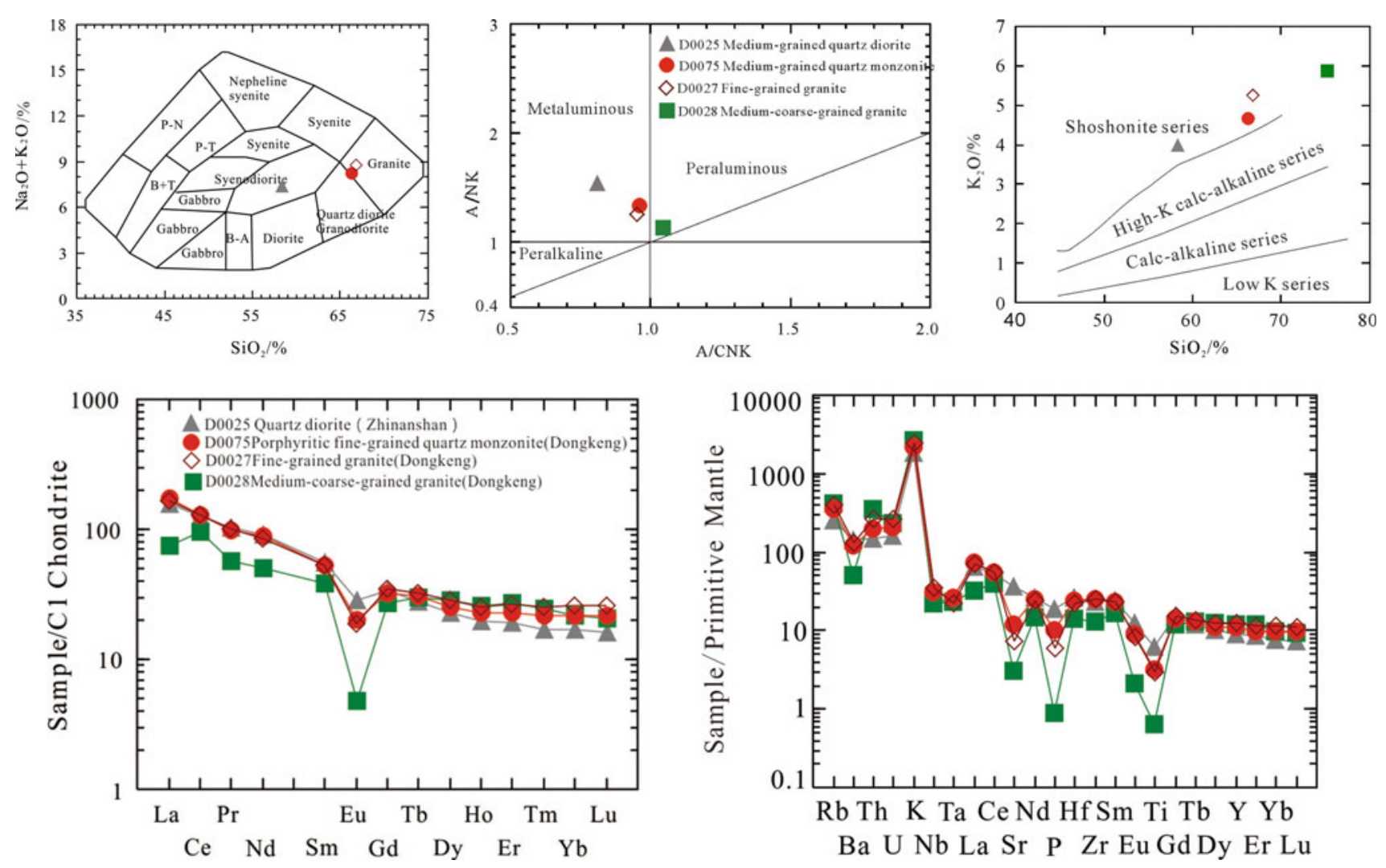

Fig. 3.39 $\mathrm{SiO}_{2}-\mathrm{Na}_{2} \mathrm{O}+\mathrm{K}_{2} \mathrm{O}, \mathrm{A} / \mathrm{CNK}-\mathrm{A} / \mathrm{NK}, \mathrm{SiO}_{2}-\mathrm{K}_{2} \mathrm{O}$, $\mathrm{REE}$ chondrite-normalized diagram, and trace element primitive mantle-normalized diagrams for the Zhinanshan-Dongkeng volcanic-intrusive complexes
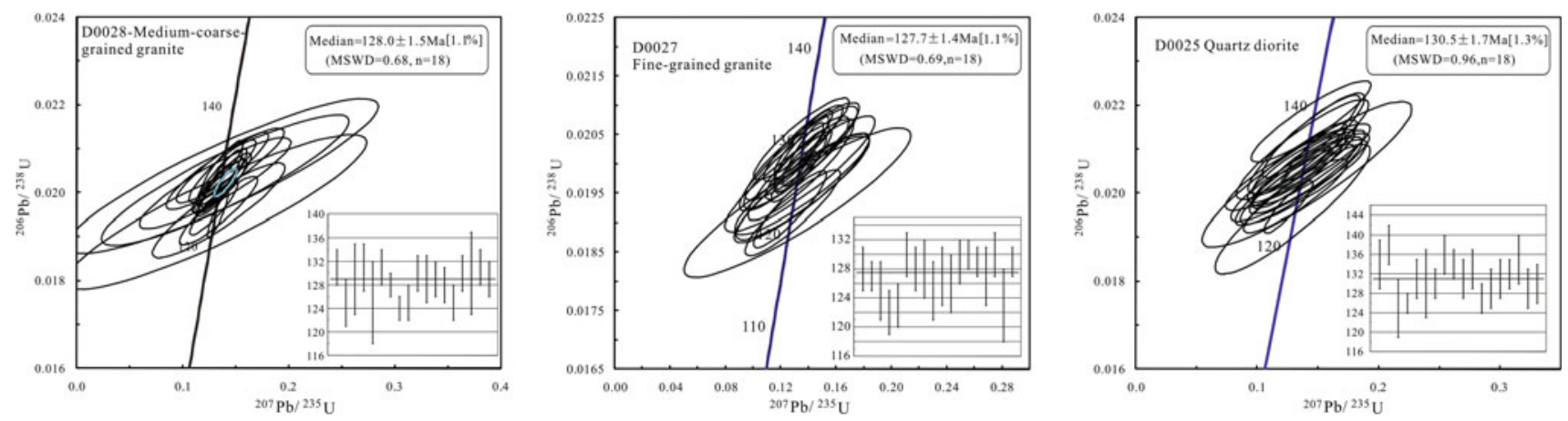

Fig. 3.40 Zircon $\mathrm{U}-\mathrm{Pb}$ concordant curve of the main types of the rock from the Zhinanshan-Dongkeng volcanic-intrusive complexes

\subsubsection{Origin, Evolution of Magma, and Its Relationship with Regional Metallogeny}

\subsubsection{Origin and Evolution Series of Magma}

\section{Evolution Series of Magma}

According to zircon $\mathrm{U}-\mathrm{Pb}$ ages, all intrusive rocks in the survey area were formed in the early stage of Early
Cretaceous. Therefore, the intrusive magma activities can be divided into three stages and two series, including intrusive rocks and volcanic-intrusive rocks, in combination with lithological compositions, contact relationships, petrological, and geochemical features (Fig. 3.41).

(1) Intrusive rock series

Stage-1 $\left(\mathrm{K}_{1}^{1}\right)$ : Zircon $\mathrm{U}-\mathrm{Pb}$ age is 145.1-136.3 Ma. According to the contact relationship, the time sequence is 


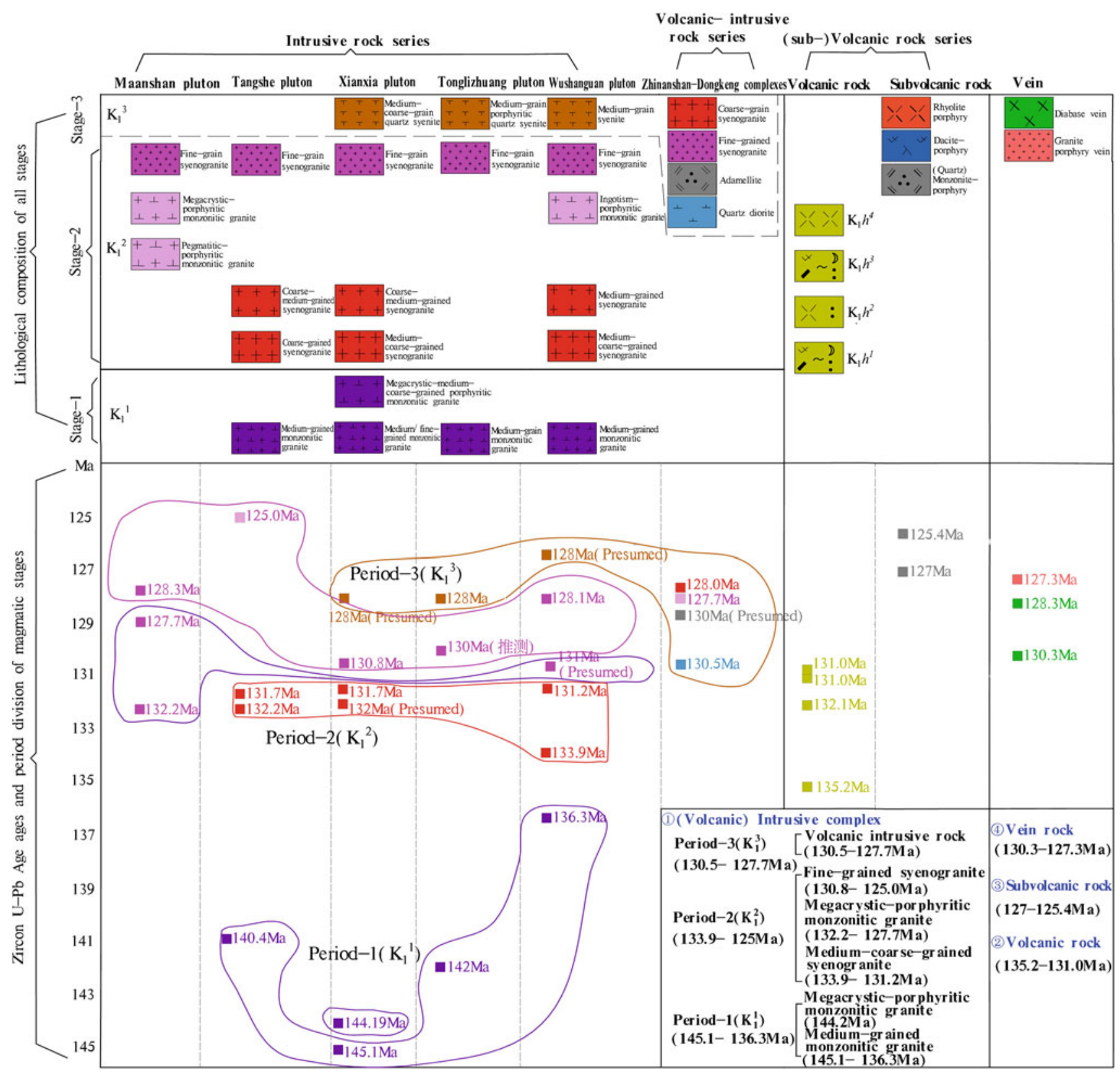

Fig. 3.41 Diagram showing lithological compositions and evolution series of magmatism in the Early Cretaceous

followed by medium-grained monzonitic granite (145.1136.3 Ma) of Tangshe, Xianxia, Tonglihuang, and Wushanguan, and megacrystic porphyritic monzonitic granite (144.2 Ma) of Xianxia.

Stage-2 $\left(\mathrm{K}_{1}^{2}\right)$ : Zircon $\mathrm{U}-\mathrm{Pb}$ age is $133.9-125.0 \mathrm{Ma}$. According to the contact relationship, the time sequence followed by coarse-medium-grained to medium-coarsegrained syenogranite (133.9-131.2 Ma) of Tangshe, Xianxia, and Wushanguan; pegmatitic and megacrystic porphyritic monzonitic granite (132.2-127.7 Ma) of Ma'anshan and Wushanguan; fine-grained syenogranite
(130.8-125.0 Ma) of Ma'anshan, Tangshe, Xianxia, Tonglizhuang, and Wushanguan.

(2) Volcanic-intrusive series

Stage-3 $\left(\mathrm{K}_{1}^{3}\right)$ : Zircon U-Pb age is $130.5-127.7$ Ma. Rocks are mainly smaller medium-grained quartz syenite in Xianxia, Tonglizhuang, and Wushanguan plutons, fine-mediumgrained quartz diorite in Zhinanshan complex and mediumfine-grained quartz monzonite, fine-grained syenogranite and medium-coarse-grained syenogranite in Dongkeng complex. 


\section{Petrogenetic types}

In the survey area, the time sequence of the intrusive rock series followed by medium-grained monzonitic granite $\rightarrow$ megacrystic porphyritic monzonitic granite $\rightarrow$ medium-coarse to coarse-medium-grained syenogranite $\rightarrow$ megacrystic-pegmatitic porphyritic monzonitic granite $\rightarrow$ fine-grained syenogranite to volcanic-intrusive rock sequences' fine-grained quartz diorite-medium-coarsegrained quartz syenite-medium-fine-grained quartz monzonite-fine-grained syenogranite-medium-coarsegrained syenogranite.

The intrusive rock series are generally characterized by high $\mathrm{SiO}_{2}$ content, high alkali content, high $\mathrm{FeO}^{\mathrm{T}} / \mathrm{MgO}$ ratio, and high DI (79.79-93.53). From early to late stage, the rock series evolved from metaluminous to weakly peraluminous, from high $\mathrm{K}$ calc-alkaline to shoshonite (Fig. 3.42), alkali $\left(\mathrm{K}_{2} \mathrm{O}+\mathrm{Na}_{2} \mathrm{O}\right)$ content and $\mathrm{K}_{2} \mathrm{O} / \mathrm{Na}_{2} \mathrm{O}$ ratio increased. These geochemical features are similar to the highly differentiated I-type Fogang granite (82-94) in South China, and the Cayu granite (82-92) in east Gangdise, Tibet ( $\mathrm{Li}$ et al., 2007). The $\left(\mathrm{K}_{2} \mathrm{O}+\mathrm{Na}_{2} \mathrm{O}\right) / \mathrm{CaO}-\mathrm{Al}-\mathrm{Zr}+\mathrm{Nb}+$ $\mathrm{Ce}+\mathrm{Y}$ diagram shows that from early to late stage, the undifferentiated granite gradually evolved into highly differentiated granite, which also indicated magma differentiation increases as time went on.

For the volcanic-intrusive rock series, $\mathrm{SiO}_{2}$ content (58.30-75.25\%), alkali content (7.33-10.02\%), $\mathrm{FeO}^{\mathrm{T}} / \mathrm{MgO}$ ratio (1.81-4.38), and DI (62.05-94.58) are varied greatly, and mostly metaluminous and shoshonitic. However, all the features above increased gradually, followed by quartz diorite $\rightarrow$ quartz monzonite $\rightarrow$ syenogranite.

Some researches demonstrate that solubility of apatite is very low in the metaluminous-weakly peraluminous magma, and would be even lower when $\mathrm{SiO}_{2}$ content increase during the process of magmatic differentiation. But in strongly peraluminous magma, the solubility of apatite increases with the increase of $\mathrm{SiO}_{2}$ content; therefore, the changing trend of $\mathrm{P}_{2} \mathrm{O}_{5}$ and $\mathrm{SiO}_{2}$ content with the evolution of magmatic differentiation can be used to distinguish between the I-type and A-type granites and S-type granitoid. In the survey area, the intrusive rocks have lower $\mathrm{P}_{2} \mathrm{O}_{5}$ content with an average of $0.04-0.17 \%$. From early stage monzonitic granite to late-stage syenogranite, the $\mathrm{P}_{2} \mathrm{O}_{5}$ content decreased with the $\mathrm{SiO}_{2}$ content increased, similar to the evolution trend of I-type granite. $\left({ }^{86} \mathrm{Sr} /{ }^{87} \mathrm{Sr}\right)_{i}$ and $\varepsilon \mathrm{Nd}$ $(t)$ also are similar to those of I-type granite in South China. As a result, intrusive rock in the survey area may be highly differentiated I-type granite. Together with A-type granite, both developed in the Early Cretaceous strata in northwestern Zhejiang and neighboring areas.

\section{Magma Sources}

Geochemical features of the major and trace elements of intrusive rocks in the survey areas indicate that the intrusive rock series from early stage monzonitic granite to late-stage syenogranite, volcanic-intrusive rock series from quartz
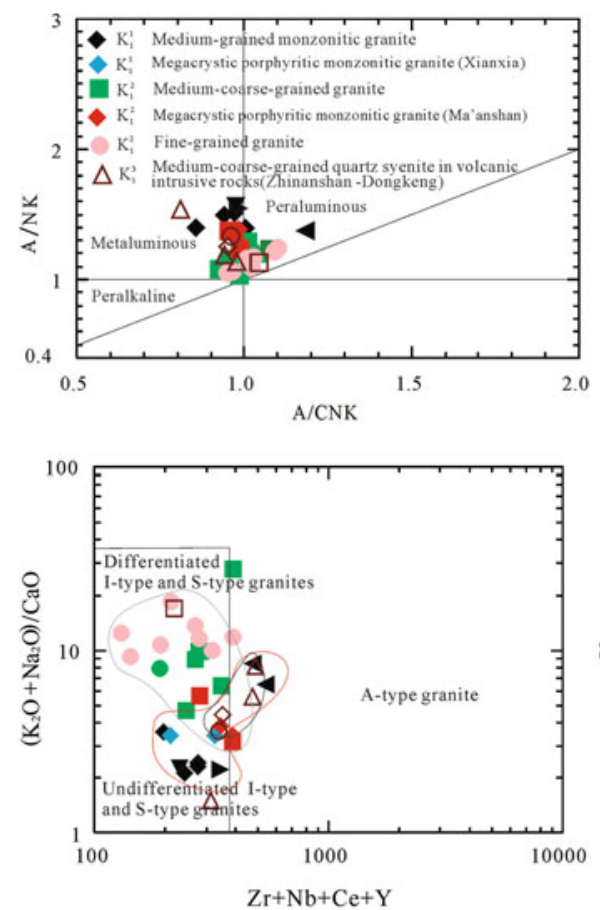
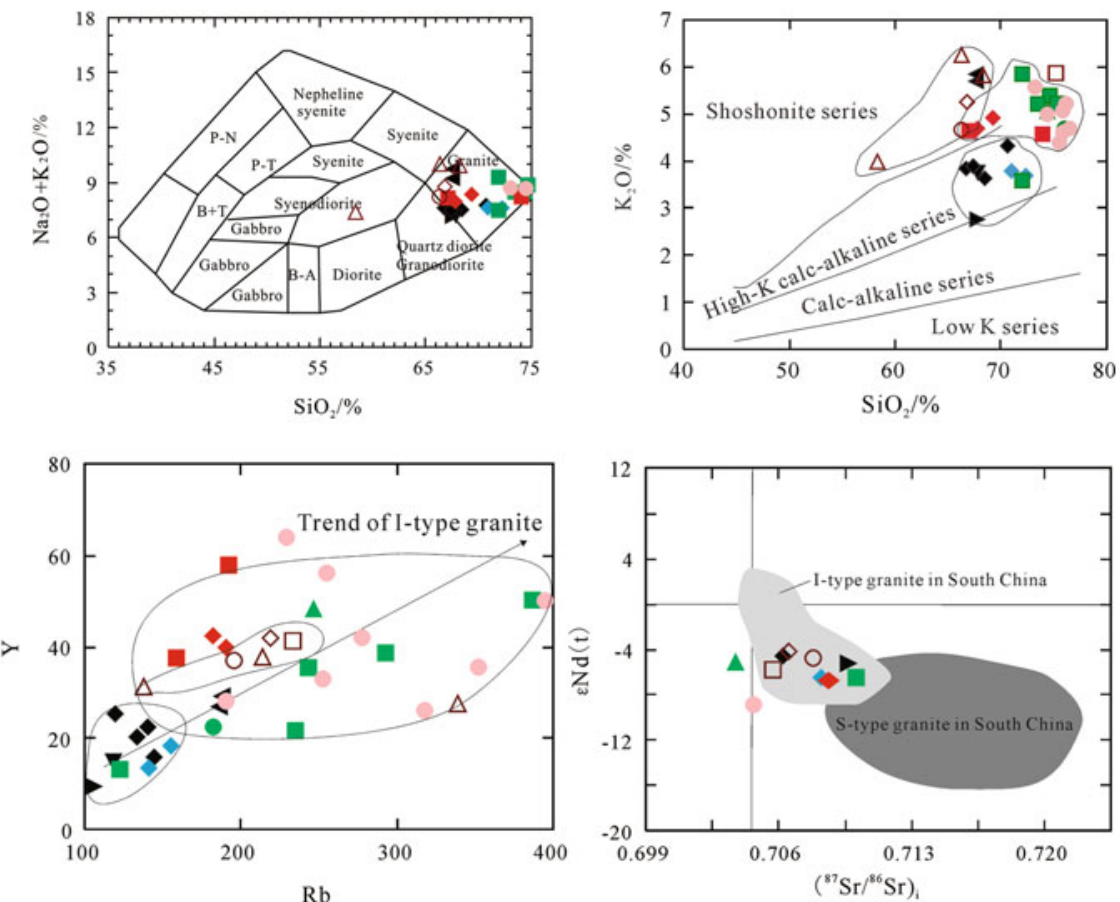

Fig. 3.42 Discrimination diagrams of intrusive rock and volcanic-intrusive rock types 
diorite to syenogranite, the content of $\mathrm{SiO}_{2}, \mathrm{~K}_{2} \mathrm{O}$, and $\mathrm{Rb}$, etc., increases gradually while the content of $\mathrm{Al}_{2} \mathrm{O}_{3}, \mathrm{CaO}$, $\mathrm{FeO}^{\mathrm{T}}$, $\mathrm{TiO}_{2}$, and $\mathrm{P}_{2} \mathrm{O}_{5}$, etc., decreases gradually, such linear relationships are obviously shown in the $\mathrm{SiO}_{2}$ Hark diagrams. In the same way, REE and trace-elements distribution patterns are very alike, from early to late, REE total and $\mathrm{Rb}$ content tend to increase, $(\mathrm{La} / \mathrm{Yb})_{\mathrm{N}}$ ratio, $\mathrm{Sr}$ content and $\mathrm{Sr} / \mathrm{Y}$ ratio tend to reduce, deficit in $\mathrm{Ba}, \mathrm{Nb}, \mathrm{Ta}, \mathrm{Sr}, \mathrm{P}, \mathrm{Eu}$, and $\mathrm{Ti}$ tends to enhance, indicating magmas are likely to have experienced highly fractional crystallization Ti-enrichment mineral facies (e.g., ilmenite and/or rutile), apatite and plagioclase or partial melting and remaining so that in late lithologies the content of minerals such as plagioclase and hornblende drops sharply; and the intrusive rock period-1 and the volcanic-intrusive rock period-3 are possibly dominated by differentiated crystallization while the intrusive rock period-2 is possibly dominated by partial melting (Fig. 3.43).

Rocks in the intrusive rock series and those in the volcanic-intrusive rock series have similar features of $\mathrm{Sr}-\mathrm{Nd}$ isotopes. For rocks in the intrusive rock series, $\left({ }^{86} \mathrm{Sr} /{ }^{87} \mathrm{Sr}\right)_{\mathrm{i}}$ is $0.69215-0.70988$ with average of $0.70536 ; \varepsilon \mathrm{Nd}(t)$ is -8.87 to -4.47 with average of -6.23 , and two-stage $\mathrm{Nd}$ model age is $1.29-1.65 \mathrm{Ga}$ and its mean value is $1.44 \mathrm{Ga}$. For rocks in the volcanic-intrusive rock series, $\left({ }^{86} \mathrm{Sr} /{ }^{87} \mathrm{Sr}\right)_{\mathrm{i}}$ is 0.70554 0.70768 and its mean is $0.70653 ; \varepsilon \mathrm{Nd}(t)$ is -5.73 to -4.19 and its mean is $-4.90, \mathrm{~T}_{\mathrm{DM} 2}(\mathrm{Nd})=$ is $1.29-1.39 \mathrm{Ga}$ with average of $1.32 \mathrm{Ga}$. Rocks in both series have high $\left({ }^{86} \mathrm{Sr} /{ }^{87} \mathrm{Sr}\right)_{\mathrm{i}}$ and their $\varepsilon \mathrm{Nd}(t)$ is higher than $\varepsilon \mathrm{Nd}(t)(-8.12$ to -9.06) of the lithospheric mantle at the north margin of Yangtze block; the $\mathrm{Nd}$ age in the stage- 2 model is close to the peak (1.6-1.7 Ga) of model age of crust-source-type granite of Yanshanian in South China (Li 1993) but lower than $\mathrm{Nd}$ model ages of basement metamorphic rocks in southwest Yangtze block $(2.0 \mathrm{Ga})$ and of Cathaysian orogenic system (1.8-2.2 Ga) (Chen and Jiang 1999), indicating that the magma source was dominated from reconstruction materials of in ancient crust, possibly with participation of a handful of mantle materials, and subsequently, mantle contributes more materials, which tallies with the geological fact that subsequently it is intruded by plenty of intermediate-basic veins. Therefore, intrusive rocks in the survey area is possibly produced from emplacement of magma under high-level crystallization segregation, which is formed by remelting crust materials in the east of the ancient Jiangnan Orogen, which is induced by magma of the lithospheric mantle of Yangtze block (Fig. 3.44), and this demonstrates that Mesozoic magma in South China succeeded Precambrian orogenic crust and mantle lithosphere materials, affected by paleo-Pacific plate subduction and rollback, with the reconstruction deformation, metamorphism, and melting of marginal materials from ancient continent under the new continental intraplate environment (Zheng et al. 2013).

Metamorphic basement in south Yangtze area (Li et al. 2003); MORB (mid-ocean ridge basalt) and OIB (oceanic island basalt) (Xia et al. 2004); lithosphere-enriched mantle cited from (Zhang et al. 2008); Yangtze lithospheric mantle, Yangtze lower crust, and crust in the east of Jiangnan orogen (Jiang et al. 2011; Wang et al. 2012); Yangtze upper crust (Wang et al. 2004); Tongcun Granodiorite porphyry (Zhu et al. 2014); Jinde granodiorite (Zhou et al. 2013); Mogan Mount granite (Zhang et al. 2012).

\subsubsection{Tectonic Environment of Intrusive Rock}

In Middle Jurassic, South China transformed from Tethys tectonic regime to Pacific tectonic regime. Many scholars investigated its tectonic settings profoundly and mainly the following ideas were obtained: (1) Lithosphere began extension in Middle Jurassic, and happened periodically until lithosphere regionally extended in Cretaceous (Chen et al. 2002; Li et al. 2007); (2) In Middle and Late Jurassic, subduction, compression, and orogenic environment of active continental margin in the Pacific tectonic regime (Xing et al. 2008; Zhang et al. 2009; Li et al. 2013) or intracontinent orogeny dominated by paleo-Pacific plate oblique-subduction (Mao et al. 2014), but extension also happens locally (Xing et al. 2008), and after collision orogeny the intracontinent
Fig. 3.43 $\mathrm{La}-\mathrm{La} / \mathrm{Yb}$ and $\mathrm{SiO}_{2-}$ $\mathrm{MgO}$ diagrams of intrusive rock and volcanic-intrusive rock (legends same as Fig. 3.42). Slab melting area (Zhu et al. 2009); lower crust melting area (Hou et al. 2004; Guo et al. 2007; Gao et al. 2010)
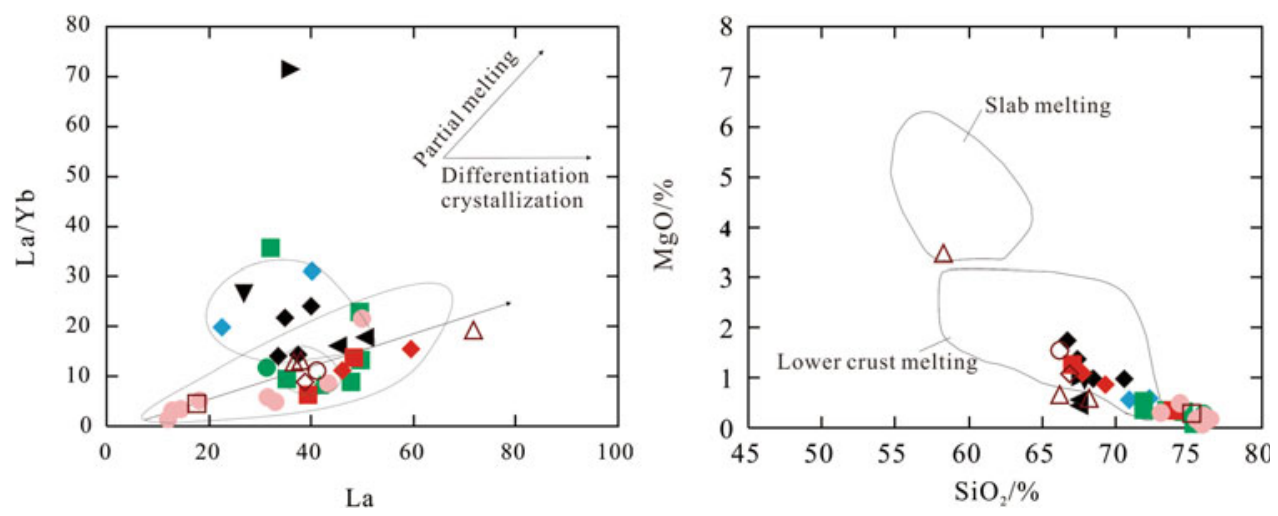
Fig. 3.44 $\left({ }^{87} \mathrm{Sr} /{ }^{86} \mathrm{Sr}\right)_{\mathrm{i}}-\varepsilon \mathrm{Nd}$ (t) and $\left({ }^{87} \mathrm{Sr} /{ }^{86} \mathrm{Sr}\right)_{\mathrm{i}}-t(\mathrm{Ma})$ diagrams of intrusive rock and volcanic-intrusive rock (legends same as Fig. 3.42)
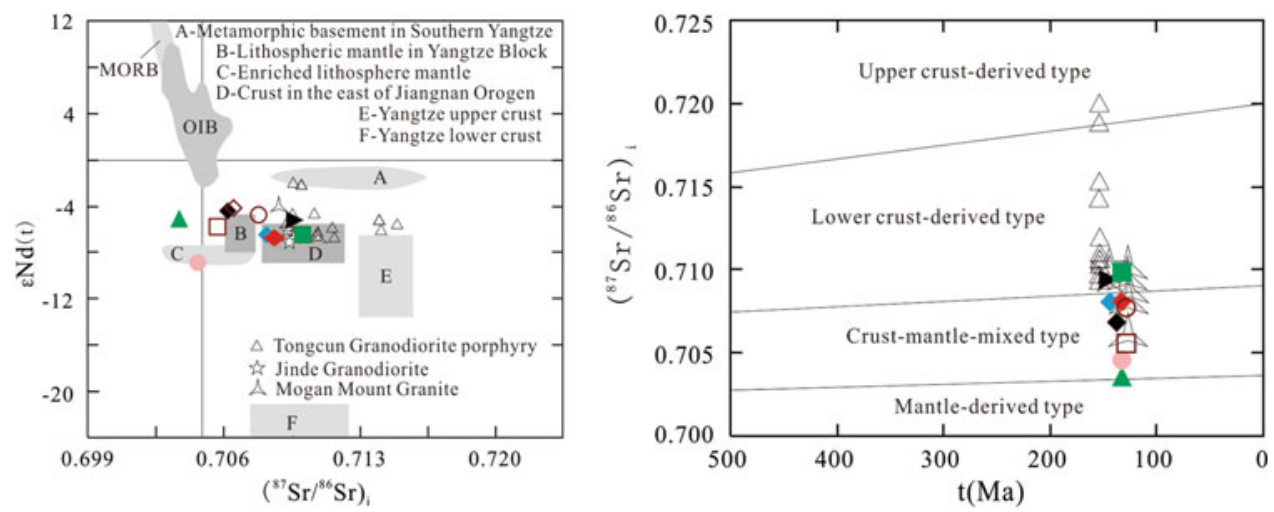

extension took place in the beginning of the Early Cretaceous ( $\mathrm{Li}$ et al. 2013; Mao et al. 2014); (3) from Middle and Late Jurassic to the beginning of Early Cretaceous, multiple blocks compressed strongly intracontinent orogeny from multiple directions (165 $\pm 5 \mathrm{Ma}-136 \mathrm{Ma})$, in the beginning of Early Cretaceous, extensional collapses and the lithospheric thinning (135-100 Ma), in the Late-EarlyCretaceous, weak compressional deformation took place (100-83 Ma) (Dong et al. 2007), stressing constraints of interactions of multiple blocks (Wang et al. 2013). Comprehensive research results show that in the northwest Zhejiang and even in South China, in Middle Jurassic $(165 \pm 5 \mathrm{Ma}-145 \pm 5 \mathrm{Ma})$, the tectonic settings were generally in an compressional environment, and transformed into extensional environment in the beginning of Early Cretaceous $(145 \pm 5 \mathrm{Ma}-125 \mathrm{Ma})$, which was triggered by the oblique and shallow subduction direction of the Izanagi plate replaced by the straight and steep subduction of the Pacific plate (Zhu et al. 2010).

Similar to intrusive rocks in northwestern Zhejiang and southern Anhui, intrusive rocks and volcanic-intrusive rocks in the survey area fall within the post-collision granite area in the $\mathrm{Rb}-\mathrm{Y}+\mathrm{Rb}$ diagram (Fig. 3.45), and also, largely fall within the later orogeny and post-orogeny areas in the $R_{1}-R_{2}$ diagram, and combined geochemical features demonstrate that intrusive rocks and volcanic-intrusive rocks in the survey area are the product of intracontinent extension after subduction orogeny in Cretaceous.

\subsubsection{Features of Magma Emplacement and Metallogenesis}

\section{Magma Emplacement Mechanism and Metallogenesis}

The relationship between granite emplacement and metallogenesis is an important topic in geological study. In general, "active" emplacing (diapirism, dome, and balloon swelling) plutons are mostly produced in closed-semi-closed environments, adverse to exchange in materials and energy between plutons as well as formation of deposits; "passive" emplacing (e.g., cauldron subsidence, stoping and structure injection) plutons are produced in open environments, conducive to formation of contact metasomatic and other magmatic-hydrothermal deposits (Ma et al. 1994; Zheng et al. 2007; Feng et al. 2009). Intrusive rock series in the survey area, e.g., Ma'anshan, Tangshe, Xianxia, Tonglizhuang, and Wushanguan plutons are clearly under control of NE-strike fold core and fracture structures as well as wall-rock contact zones, thus having the feature of "passive" joint emplacement mechanism of stoping and structure injection. The Early Cretaceous mineralization types in the region are the contact metasomatic skarn type and medium-low temperature magmatic-hydrothermal type, which are different in mineralization characteristics and degree; mineralization associated with stoping emplacing pluton mainly happened at the contact zone of pluton which is in the shape of lenticle, balloon, and lamination, and of which the attitude always varies with the structure of the contact zone, for instance, skarn-type $\mathrm{Pb}-\mathrm{Zn}$ polymetallic deposits are produced on the outer contact zone of Tangshe and Tonglizhuang plutons; mineralization associated with structure injection emplacing pluton mainly took place in the fractures of pluton and its wall rocks, pluton is often in the shape of stable and steep vein and lamination, the mineralization type is medium-low temperature magmatichydrothermal type, for instance, the magmatichydrothermal fluorite deposit formed at the margin of Ma'anshan megacrystic-pegmatitic monzonitic granite, and the quartz veinlet-stockwork W-Mo orebodies developed in the contact zone of Tonglizhuang-grained syenogranite.

In addition, magma ascent and emplacement is not only under control of multiple factors but also a process of formation, growth, and evolution itself. Change in the emplacement mechanisms in the process of ascent and emplacement, as well as resultant changes in physiochemical conditions of mineralization, may result in vertical zonation 

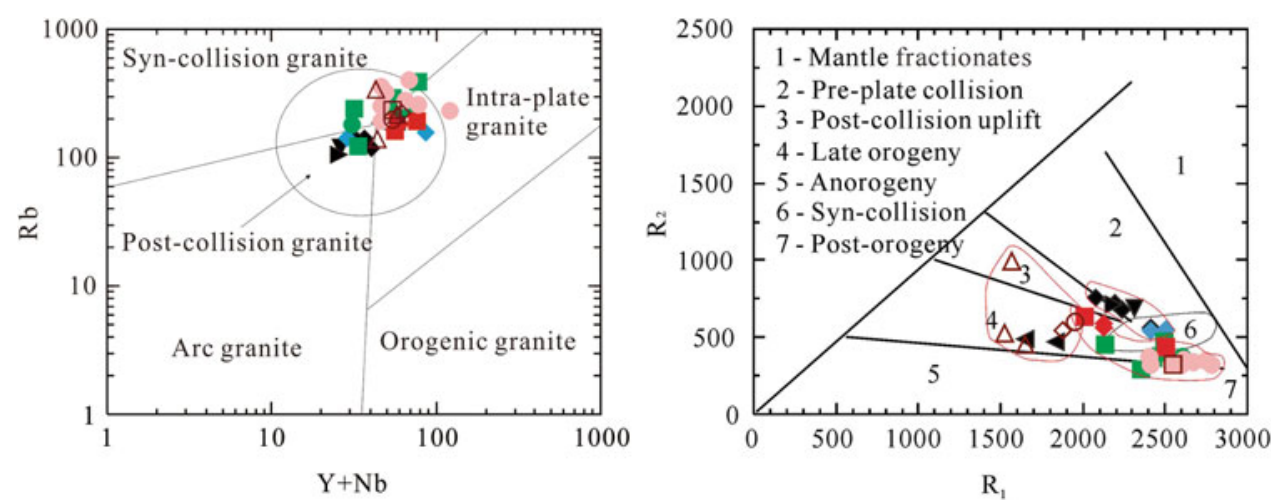

Fig. 3.45 $\mathrm{Y}+\mathrm{Nb}-\mathrm{Rb}$ and $R_{1}-R_{2}$ diagrams of intrusive rock and volcanic-intrusive rock (legends same as Fig. 3.42)

of ore deposits associated with the emplacement mechanism and the ore-controlling factors; metallogenic ability of granite is closely related to granite magma fractionate and evolve, in perspective of the continuity of composite pluton in the process of magmatic differentiation evolution from same source, it is often an intrusion body in a composite pluton series, and usually is a late intrusion body, because the more thorough magmatic differentiation the higher it evolves, the easier it is to form fluids that are enriched in metallogenic elements (Feng et al., 2009). This also demonstrates that some granite plutons' contact structure systems in the survey area may show a feature of horizontal zonation, for instance, Tangshe composite pluton, due to difference in distance to pluton and metallogenesis period, the mineralization type varies from quartz veinlet-stockwork type and skarn-type to structure alteration type or hydrothermal vein type, producing a rule of evolution from $\mathrm{Wu}-\mathrm{Sn}-(\mathrm{Pb})-\mathrm{Ag}$ to fluorite in terms of ore deposit types; geochemical researches indicate that, intrusive rock within the area are high-level fractionation, and differentiation enhances gradually from monzonitic granite to syenogranite in the intrusive rock series, showing a feature favoring $\mathrm{Cu}-$ Mo-W $\rightarrow \mathrm{W}-\mathrm{Mo} \rightarrow$ Mo porphyry metallogenic evolution (Fig. 3.46), which is consistent with the feature that the known W-Mo and Mo deposits (ore occurrences) within the area are closely related to the distribution of fine-grained syenogranite, contact zones have often developed quartz fine-vein $\mathrm{W}-\mathrm{Mo}$ and $\mathrm{Pb}-\mathrm{Zn}$ polymetallic skarn, a main mineralization type in the survey area. But the prospecting potential for porphyry $\mathrm{W}-$ Mo deposits may exist in the deep.

\section{Pattern of Emplacement Growth and Metallogenesis of Plutons}

Plutons of the same periods, even though they are basically identical in size, form, and geochemical components, differ greatly in whether their contain minerals and whether their mineralization is strong or weak, and their mineralization may vary from each other; the reasons are different

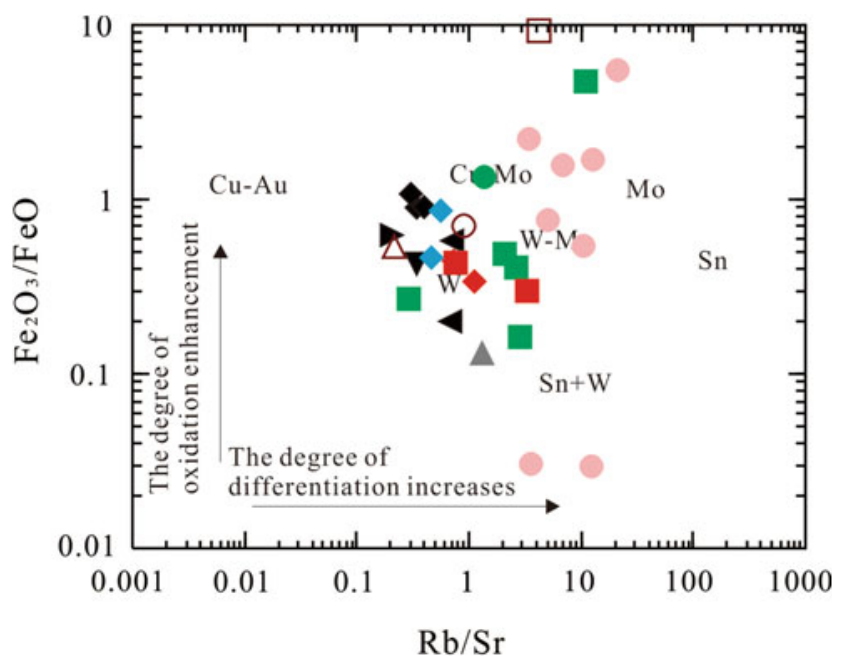

Fig. 3.46 Intrusive rock and volcanic-intrusive rock $\mathrm{Rb} / \mathrm{Sr}-\mathrm{Fe}_{2} \mathrm{O}_{3} /$ $\mathrm{FeO}$ diagrams (legends same as Fig. 3.42) (Blevin 2003)

emplacement mechanism will trigger different metallogenesis on one hand and different pattern of pluton emplacement and growth impact its metallogenic features and patterns on the other hand (Wu 1998; Rui et al. 1991). And the composite pluton's multiple pulsation emplacement process is the aggregation process the same magmatic source, in the ways of phasal accretion growth, emplace, and superimpose inside or around the intrusion body that emplaces initially, and finally a composite pluton in concentric-annular-belt, semi-annular-belt or irregular shape is produced; Here, granitic body in the concentric-annular-belt shape (including semi-annular-belt) is divided into "positive annular-belt (inner intrusion)" and "reverse annular-belt (outer intrusion)" and the former is common (Feng et al. 2009).

In the survey area, though there are similar emplacement mechanisms for Early Cretaceous composite plutons, finding a location at one off, a vast majority of granite pluton have gone through continuous and complex (very short between two explacements) pulsant emplacement growth process. Here, Ma'anshan pluton and Dongkeng volcanic-intrusive plutons show a positive annular-belt, the central unit 
(syenogranite) is later than the emplacement of the marginal units (monzonitic granite and quartz monzonite), the pluton accretes from outer to inner, "inner intrusion" (Fig. 3.47); Tangshe, Xianxia, Wushanguan, and Tonglizhuang plutons are composite plutons in the positive annular-belt-irregular shape, "inner intrusion" or "outer intrusion" accretion in some areas and randomly, no obvious rule in other areas (discrete) (Fig. 3.47). Within the area, the distribution features of known deposits (ore occurrences) related to magmatism also show the intrusive outer contact zones of composite plutons such as Tonglizhuang, Wushanguan, Tangshe, and the northeast section of Xianxia have developed skarn-type polymetallic deposits and quartz veinlet type Mo deposit, Ma'anshan pluton is mainly vein-type deposit but there is no mineralization in Dongkeng volcanic-intrusive pluton. Such metallogenic features indicate that in the condition of the same emplacement mechanism, for granitic pluton, which is formed through multiple period pulsation and owns the way of "outer intrusion" accretion, magma that emplace late may contact sedimentary wall rocks so as to exchange frequently materials and energy, it is prone to generate contact metasomatic deposit and hydrothermal deposits surrounding the pluton, and a vast majority of granite plutons in South China that are closely related to such ore deposit types are granite plutons with relatively small size and have reverse annular-belt structure and formed in the way of outer intrusion accretion; however, for inner intrusion granite plutons, since magma that late emplacement is unable to directly contact sedimentary wall rocks, it is not prone to generate contact metasomatic deposits and hydrothermal deposits. However, if late-stage magma contains enrichment high-temperature hydrothermal fluids, it can intruded upward and even puncture early plutons resulting in occurrence of metallogenesis, and thus pegmatite or porphyry (porphyrite) deposits, as well as greisen-vein-type deposits, are formed in or on the top of plutons (Feng et al. 2009).

\subsection{Volcanic Rocks}

\subsubsection{Overview}

In the survey area, volcanic rocks are mainly located in the east half of Xianxia Mapsheet and Chuancun Mapsheet with outcropping of $556 \mathrm{~km}^{2}$, distributed a normal trapezoid. Its northern side, bordering with Baofuzhen, Anji-Wushanguan, Yuhang District, is in angular unconformable contact with Paleozoic sedimentary strata and in intrusive contact with Wushanguan composite pluton; its southern side, bordering with Majiafan-Gaolingcun-Linbeicun, Lin'an City, is in angular unconformable or fault contact with Paleozoic sedimentary strata; its western side, bordering with Dengcun, Lin'an City-Zhangcunzhen, Anji

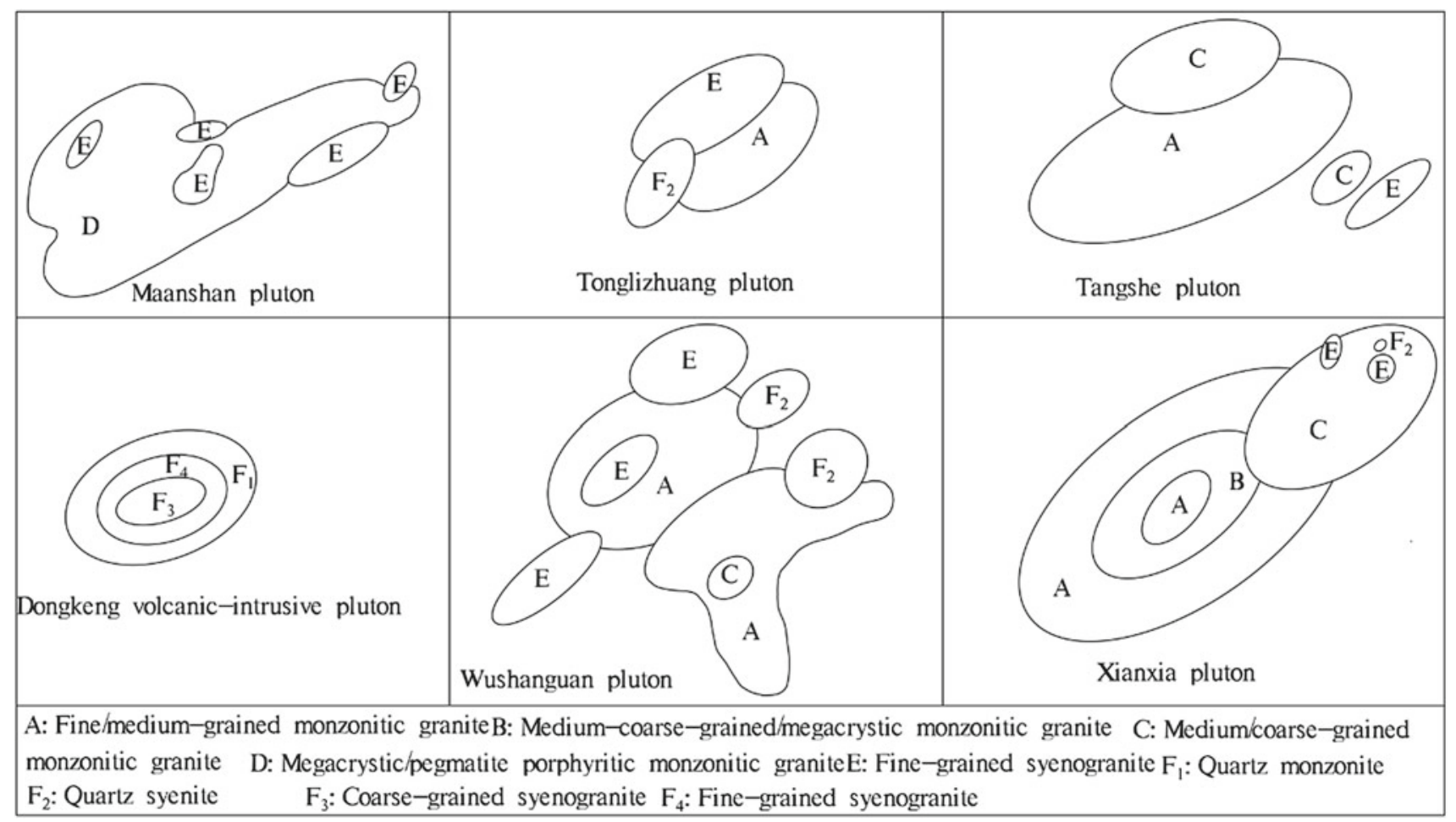

Fig. 3.47 Sketch showing the model for accretion growth ways of pluton in the survey area 
County, in NE-strike fault contact with Paleozoic sedimentary strata an Xianxia composite pluton; it eastern side, bordering with Xianbaikengcun-Langjiacun, Yuhang District, is in intrusive or NW-strike fault contact with Wushanguan composite pluton.

In the survey area, volcanic rock belongs to Yianmu Mount-Mugan Mont volcanic structural depression of Tingzi Mount-Tianmu Mount-Mogan Mount sunzone of the active volcanic zone in northern Zhejiang. With many types of rocks and complex lithologies, volcanic rocks are characterized by great changes in lithofacies combinations, developed volcanic apparatus and multiple eruptions and migrations. On the basis of volcanic rock's distribution features, lithological and lithofacies combination as well as regional comparison, in the survey area, volcanic rockfalls within Mesozoic Huangjian Formation, and can be divided into four eruption rhythms (stratum unit at member level) by volcanic eruption from early to late and from strong to weak.

\subsubsection{Rock Types and Features}

In the survey area, volcanic rock has a number of rock types, can be mainly divided into four categories: volcanic clastic rocks, volcanic sedimentary rocks, lavas, and subvolcanic rocks, and rocks are named mainly by referencing to classification and naming schemes for volcanic clastic rocks in Research Report on Volcanic Structure-Lithology and Lithofacies-Volcanic Strata Mapping Methods, and other categories of rock are named as per this.

\subsubsection{Volcanic Clastic Rock}

In the survey area, there are various types of volcanic clastic rock with main lithology, including rhyolitic agglomerate breccia, rhyolitic agglomerate breccia tuff, rhyolitic/dacitic (breccia-bearing) crystal-vitric tuff, rhyolitic/dacitic (breccia-bearing) crystal-vitric ignimbrite, and rhyolitic/dacitic vitric ignimbrite, etc.

\section{Rhyolitic daciticacitic tuff (ignimbrite)}

It is the main lithology of the Member \#1 $\left(\mathrm{K}_{1} h^{1}\right)$ and \#3 $\left(\mathrm{K}_{1} h^{3}\right)$ of Huangjian Formation and the lithology consists of rhyolitic dacitic breccia-bearing crystal-vitric ignimbrite, rhyolitic dacitic agglomerate-breccia-bearing crystal-vitric ignimbrite, rhyolitic dacitic crystal-vitric ignimbrite, and rhyolitic dacitic crystal-vitric tuff, etc. Hereunder, describes its main lithological features:

\section{(1) Rhyolitic dacitic (breccia-bearing) crystal-vitric ignimbrite}

Mostly gray and offwhite, (breccia-bearing) ignimbrite texture, and massive structure; rock outcropping is obviously coarser that the lava type, and undeveloped joints structure; crystal pyroclast is mainly light-offwhite plagioclase (5$15 \%), \mathrm{K}-\mathrm{Na}-\mathrm{feldspar}(5-10 \%)$ and a handful of quartz (1\%), in the grain size of $0.5-1.5 \mathrm{~mm}$; debris breccia is dark graylight gray, with content of $1-5 \%$, in subangular or subrounded shape, mainly rhyolite, dacite, andesite, and ignimbrite, etc., in the size of $0.5-1.5 \mathrm{~mm}$ for debris and $2-$ $8 \mathrm{~mm}$ breccia. Plagioclase mostly in the angular and subhedral column shapes, some have Na-feldspar bicrystal and annular-belt structure; K-feldspar is mostly in the angular shape, and less in the shape of subhedral plate and column; quartz mostly in the angular shape and less in the shape of hexagonal bipyramid; dark minerals are mainly hornblende, biotite or augite, mostly replaced by chlorite and carbonatite, etc. Plastic vitroclastic, rock debris, and volcanic ash are 74$89 \%$ in content, plastic vitric is mostly in the rod-like, earthworm-like or irregular shape, and largely arranged directionally in rock; plastic rock debris in the shape of long strip, ripped, and lenticles, and it has been devitrified to be felstic and crystal-particle-like felsic minerals.

(2) Rhyolitic dacitic agglomerate-breccia-bearing (vitric) ignimbrite

Offwhite and gray, breccia-bearing crystal-vitric-plasticized tuffaceous texture and false-rhyolitic structure; agglomerate is about $5 \%$ in content and $6-10 \mathrm{~cm}$ in size, while breccia is $15 \%$ in content and $2-3 \mathrm{~cm}$ in size, agglomerate and breccia are mainly in the angular-subangular shape, mainly are crystal-vitric ignimbrite, vitric ignimbrite, and crypto-crystal siliceous, etc.; crystal pyroclast is mainly quartz (1-2\%), K-feldspar (10-15\%), and plagioclase (5-10\%), some rock's crystal pyroclast is up to $30 \%$ in content, $0.2-1 \mathrm{~mm}$ in size, and up to $1.5 \mathrm{~mm}$ for less. Rocks have a handful of gray-green magmatic-fragment strips which are intermittently arranged directionally, and stripe is $5-30 \mathrm{~mm}$ (length) $\times 1-5 \mathrm{~mm}$ (width).

\section{Rhyolitic ignimbrite}

It is the main lithology of Member \#2 of Huangjian Formation $\left(\mathrm{K}^{1} h^{2}\right)$ and the lithology consists of rhyolitic (breccia-bearing) crystal-vitric ignimbrite, rhyolitic agglomerate-breccia-bearing crystal-vitric ignimbrite, and 
rhyolitic crystal-vitric ignimbrite. The features of rhyolitic (breccia-bearing) crystal-vitric ignimbrite are:

Rock varies greatly in color, dark red, light purple, gray purple, gray, offwhite, and gray green, (breccia-bearing) ignimbritic texture and false-rhyolitic structure. In the rock, breccia is $5-10 \%$ in content, containing mainly gray green, dark gray and gray yellow ignimbrite, tuff or cryptocrystalline, some breccia are directionally arranged, in the size of 2-15 mm for most, $20-30 \mathrm{~mm}$ for some and up to $80 \mathrm{~mm}$ for a few (agglomerate), in the subangular-subrounded shape; crystal pyroclast is mainly light pink K-feldspar (5$10 \%)$, quartz (5-10\%), and plagioclase (5\%), in the size $0.5-$ $2 \mathrm{~mm}$, and 3-4 $\mathrm{mm}$ for a few, cemented with tuffaceous. $\mathrm{K}$-feldspar is most in the angular shape, less in the shape of plate-like and column and occasionally Carlsbad twin visible; plagioclase is mostly in the shape of subhedral plate and column, Na-feldspar bicrystal often visible and annular-belt structure occasionally visible; quartz is mostly in the shape of angle and hexagonal bipyramid, occasionally in corrosion curved shape at the margin; dark minerals are mainly hornblende and biotite, which has been altered to be clay minerals. In the rock, plastic vitric pyroclast and volcanic ash are $60-82 \%$ in content, plastic vitric pyroclast is in the shape of bar, rod, strip, and fine stripe, and has been devitrified to be felsitic felsic minerals; plastic debris content is $1-10 \%$, in the shape of lenticles, ripped, and striation, after devitrification it becomes felsitic texture and crystal micro-granular texture, K-feldspar, plagioclase, and quartz phenocryst; plastic vitric pyroclast and debris are clearly directionally distributed forming rhyolitic structure.

\section{Rhyolitic tuff}

It is a lithology of the lower part of Member \#2 of Huangjian Formation $\left(\mathrm{K}_{1} h^{2}\right)$ and the lithology consists of rhyolitic agglomerate-bearing (breccia-bearing) crystal-vitric tuff, rhyolitic breccia-bearing crystal-vitric tuff, and rhyolitic crystal-vitric tuff. Taking the lithology at the lower part of Member \#2 of Huangjian Formation $\left(\mathrm{K}_{1} h^{2}\right)$ East Tianmu Mount Scenic Area as an example, hereunder describes its main lithological features:

(1) Rhyolitic agglomerate-bearing breccia(-bearing) crystal-vitric tuff

Purple red, agglomerate-breccia-bearing tuff texture and massive-laminated structure, in the thickness of $1-5 \mathrm{~m}$; breccia is about $20 \%$ in content and $1-6 \mathrm{~cm}$ in size $(15 \%)$, and $2-10 \mathrm{~mm}$ for a few (5\%); agglomerate is about $10 \%$ in content, $6-20 \mathrm{~cm}$ in size $(8 \%)$, and $20-40 \mathrm{~cm}$ for a few
(2\%); agglomerate breccia is in the subrounded shape, not clear in sorting, in general, the content of agglomerate breccia is low in the upper and lower parts, more in the mid-part; agglomerate breccia has consistent component which is rhyolitic crystal-vitric ignimbrite. In rocks, crystal pyroclast is $30 \%$ in content, locally become rhyolitic crystal pyroclast tuff, crystal pyroclast is mainly feldspar $(15 \%)$ and quartz $(15 \%)$, in the size of $1-2 \mathrm{~mm}$; cemented with tuffaceous. The mid of the stratum has developed interbeddings of purple-red siltstone $(10 \mathrm{~cm})$ and gray-green tuffite (about $1 \mathrm{~m}$ thick), whose attitude is $90^{\circ} \angle 40^{\circ}$ and $50^{\circ} \angle 50^{\circ}$.

\section{(2) Rhyolitic agglomerate-bearing breccia}

Purple red and dark red, agglomerate-bearing breccia texture, and massive structure; agglomerate and breccia are mainly rhyolitic crystal-vitric ignimbrite; agglomerate is $10 \%$ in content and $6-25 \mathrm{~cm}$ in size, in the round and subangular shape, up to $60-70 \mathrm{~cm}$ for a few; breccia is $50-$ $60 \%$ in content and $10-50 \mathrm{~cm}$ in size; crystal pyroclast is mainly quartz (4\%), K-Na-feldspar (20\%), and plagioclase (2\%), and a handful of biotite, in the grain size of $0.2-$ $1.5 \mathrm{~mm}$; cemented with tuffaceous.

\subsubsection{Volcanic Sedimentary Rock}

It is the main lithology at the upper part of the Member \#1 of Huangjian Formation's $\left(\mathrm{K}_{1} h^{1}\right)$, additionally, a handful of it is distributed at the lower part of the Member \#1 of Huangjian Formation $\left(\mathrm{K}_{1} h^{1}\right)$ and the Member \#3 of Huangjian Formation $\left(\mathrm{K}_{1} h^{3}\right)$ in the form of interbeddings (for instance, Tianhuangping and Lichanglong Mount), and lithology includes tuffaceous glutenite, tuffaceous (gravel-bearing) packsand-siltstone, and tuffite, etc.

\section{Tuffaceous Glutenite}

It is mainly distributed at Dashulin area of Dengcun Village, Lin'an District, and Hangzhou City. It is gray, gravel-bearing coarse-sand texture and mainly contains gravel and sand. Gravel is $30-35 \%$ in content, in the size of 2-500 mm varying greatly, generally in the round, subangular, subrounded, long-flat, and irregular shapes, contains complex and various components, mainly sandstone (20\%), quartz $(5 \%)$ and volcanic rock $(75 \%)$, etc.; sand is $70 \%$ in content, in the size of $0.1-2 \mathrm{~mm}$, in the round, subangular, and subrounded shape, mainly debris $(65 \%)$, quartz $(20 \%)$ and felsdpar (15\%); demented with tuffaceous. Rock is 70 $150 \mathrm{~cm}$ thick per layer and inside a handful of gravel is arranged in oblique rows. 


\section{Tuffaceous (gravel-bearing) fine-siltstone}

It is mainly distributed at Shenxi Village Canyon and Tianhuangping area, Baofu Town, Anji County.

Rock at Shenxi Village Canyon is purple red, mediumthin-laminar structure, has minute rhythmic bedding, gravel-bearing coarse-fine-silt texture, in the interbedded shape; purple-red tuffaceous gravel-bearing gritstone stratum, purple gritstone stratum, purple packsand stratum, and dark purple silty mudstone are $10-20 \mathrm{~cm}, 10-30 \mathrm{~cm}, 5-$ $10 \mathrm{~cm}$, and $5-8 \mathrm{~cm}$ in thickness, respectively, with the attitude of $180^{\circ} \angle 20^{\circ}$. Rocks contain a handful of plagioclase whose content is $3-5 \%$ and size is $1-3 \mathrm{~mm}$; a handful of dark-black and gray-green angular tuff breccia locally seen, in the content of $2-3 \%$ and size of $3-10 \mathrm{~mm}$; the lithology at the top is gray-black carbonaceous argillaceous siltstone. Terrigenous clast is $80-85 \%$ in content and mainly is silty-fine sand (65-70\%), argillaceous (15\%), and irony $(5 \%)$. Silty-fine sand is mainly quartz, and a handful of debris, in the angular shape, evenly distributed; argillaceous is cryptocrystalline; irony is limonite, in rendered shape. Volcanic clastic is $10-15 \%$ in content, mainly crystal pyroclast (mainly plagioclase, and a handful of quartz), and a handful of volcanic cinder, pretty evenly distributed in the terrigenous clastics.

At Tianhuangping area, tuffaceous gravel-bearing packsand or siltstone is interbedded with sedimentary breccia crystal-vitric tuff, purple red and brown, medium-thin lamellar, locally interlined with medium-thin-lamellar tuffite, about 5-30 cm thick per layer; in the shape of intermittent long strips and bubbles, tuffaceous packsandy texture, composed of volcanic clastics (25\%), silt and argillaceous (75\%), volcanic ash and cemented with argillaceous. Gravel is in the subangular shape and in the grain size of $0.1-0.25 \mathrm{~mm}$, mainly feldspar and secondly quartz.

\section{Tuffite}

It is distributed at the lower part of the Member \#1 of Huangjian Formation $\left(\mathrm{K}_{1} h^{1}\right)$ and its Member \#3 $\left(\mathrm{K}_{1} h^{3}\right)$ in the form of interbedding, for instance, tuffite at Tianhuangping area, light offwhite, weakly weathered, with the surface in the shape of smooth ellipse; composed of volcanic clastics (75$80 \%)$, silt and argillarceous (20-25\%). Sand is fine grained, mostly $0.01-0.03 \mathrm{~mm}$ in size, and is mainly quartz, etc.

\subsubsection{Lava}

It the main lithology of the Member \#2 of Huangjian Formation, there are complex and various rocks, mainly massive rhyolitic porphyry, rhyolitic tuff lava, rhyolitic agglomerate breccia lava, porphyritic rhyolitic, and bubble rhyolite.

\section{Massive rhyolitic porphyry}

It is mainly distributed at Shenxi Village Canyon, Baofu Town, in Xianxia Mapsheet, and based on features of texture and structure, and it can be divided into (breccia-bearing) vitric massive rhyolitic porphyry, felstic massive rhyolitic porphyry, and felsitic massive porphyritic rhyolitenevadite.

\section{(1) (breccia-bearing) vitric rhyolitic porphyry}

Gray and gray black, breccia-bearing porphyritic texture, and massive structure. Phenocryst is $10-15 \%$ in content and 1$2 \mathrm{~mm}$ in size, but up to $3 \mathrm{~mm}$ for few, mainly K-Na-feldspar $(10 \%)$ and plagioclase $(5 \%)$, a handful of biotite, in the granular or crushed granular shape. Breccia is $2-3 \%$ in content, in the angular-subangular shape, $2-15 \mathrm{~mm}$ in size, purple, gray, and black cryptocrystalline. Matrix is dark gray vitric lava.

\section{(2) Felsitic massive rhyolitic porphyry}

Light gray and gray, porphyritic texture, and massive structure. Phenocryst is $10-30 \%$ in content, mainly light pink K-feldspar and a handful of plagioclases, in the size of 1-3 $\mathrm{mm}$ and in the short column, granular, and irregular shapes. Matrix is light gray felstic lava cementation. Outcropping locally, K-feldspar porphyroclast is indistinctly seen on the weathered surface, NE6 $0^{\circ}$-strike $\left(330^{\circ} \angle 10^{\circ}\right)$ directional arrangement and rhyolitic structure, and $\mathrm{K}$-feldspar porphyroclast featuring that it can be collaged.

\section{(3) Felsitic nevadite}

Gray, porphyritic texture, and massive structure. Phenocryst is $30-50 \%$ in content, and mainly light pink K-feldspar (25$40 \%$ ) and a handful of offwhite plagioclase (5-10\%), in the grain size of 1-3 mm generally, 4-5 $\mathrm{mm}$ for a few and up to 6-10 mm for individual K-feldspar phenocryst; K-feldspar is in the shape of plate and column, and Carlsbad twin occasionally seen; plagioclase is mostly in the shape of subhedral plate and column, Na-feldspar bicrystal often seen, a few like porphyritic; under the microscope, biotite and hornblende have been altered into chlorite and carbonate minerals; quartz is mostly in hexagonal bipyramid shape. Matrix is $50-70 \%$ in content, imbedded-crystal and felsitic, microcrystallite and micro-granular textures, etc., mainly cryptocrystalline felsitic or felsitic felsic minerals, in the grain size of $0.005-0.05 \mathrm{~mm}$.

\section{Porphyritic (bubble) rhyolite}

It is main lithologies of the Member \#2 of Huangjian Formation $\left(\mathrm{K}_{1} h^{2}\right)$, East Tianmu Mount-Shimen Village, Lin'an 
District, Hangzhou City; also, those of the Member \#4 of Huangjian Formation $\left(\mathrm{K}_{1} h^{4}\right)$ along West Tianmu MountLongwang Mount, and along Shifosi, Shanchuang Town, and lithology is mainly porphyritic rhyolite and bubble rhyolite.

Porphyritic rhyolite, light gray, porphyritic texture, bubble-rhyolitic structure, the content of phenocryst varies greatly, more rocks in the central, and less in the margins, mainly K-feldspar (5-20\%), and a handful of plagioclase (1$2 \%$ ) and biotite (1-2\%). K-feldspar and plagioclase are in granular and short strip shapes, in the size of 1-3 1 1-2 mm, some of it has been epidotized; biotite is in the form of schistose agglomerate, in the size of 1-3 $\mathrm{mm} \times 1-3 \mathrm{~mm}$. Rocks at margins have developed bubble in the content of 5$10 \%$ and in the size of $3-15 \mathrm{~mm}$, and rocks in the central have less or not bubble, Rocks have developed rhyolitic strip structure and eddy-like structure. K-feldspar and plagioclase are in the shape of subhedral plate and column, the former surface is argillization of different degrees, the latter surface has altered into sericite and some has Na-feldspar bycrystal; quartz is in the shape of hexagonal bipyramid and some show cataclastic phenomenon; dark minerals have been fully decomposed into chlorite, sericite, and carbonatite, etc., but on the basis of their features such as preserved appearance and transection, it is known they are mainly hornblende, biotite, or augite. Matrix is 75-93\% in content, cryptocrystalline, felsitic, and crystal micro-granular textures, micro-graphic, spherulitic, and cataclastic textures sometimes, mainly felsic minerals, in the partizle size of $0.005-0.05 \mathrm{~mm}$.

Bubble rhyolite, of which the most developed is at the mountain top of Shifosi, Shanchuang Town, and bubble is $50-60 \%$ in content and in the size of $2-15 \mathrm{~mm}$, but $15-$ $80 \mathrm{~mm}$ for a few.

\section{Rhyolitic tuff lava}

It is mainly distributed at Gaoling Village-Zhinanshan Village, Lin'an District, Hangzhou City, with bigger outcropping and thickness. Rocks are light pink, pink and light gray with porphyritic texture, and matrix is of felsitic-minute-grained texture; phenocryst is mainly $\mathrm{K}-\mathrm{Na}$-feldspar (15-30\%), plagioclase (5-10\%), and biotite (1-3\%), and very few quartz, in the grain size of 1-2 $\mathrm{mm}$ in general and 2-2.5 $\mathrm{mm}$ for a few, and a few of $\mathrm{K}$-feldspar is in the shape of long column, about $8 \mathrm{~mm}$ long and $2 \mathrm{~mm}$ wide. Matrix is feldspar (20-30\%) and quartz (37-49\%), in the grain size of $0.02-0.04 \mathrm{~mm}$.

\section{Rhyolitic agglomerate-breccia-bearing lava}

Only seen in Yangjiashan volcanic vent, light purple gray and gray green, etc., breccia agglomerate lava texture, massive structure, mainly breccia (3-5\%), agglomerate (5$10 \%)$ and crystal pyroclast $(<5 \%)$, etc., breccia and agglomerate are gray-green andesite, in the subangular- subrounded shapes, and in the size of $5-50 \mathrm{~cm}$; crystal pyroclast is mainly K-feldspar, plagioclase, quartz, and a handful of biotite, in the grain size of $0.05-1 \mathrm{~mm}$, but up to $1.5-3 \mathrm{~mm}$ for a few. Since it is in the volcanic vent, it has universally developed alterations such as silicification, chloritization, carbonatization, and pyritization.

\subsubsection{Subvolcanic Rock}

It is distributed in Shenxi Village Canyon pitching up Tianpingshan ding-Dongling, Tianhuangping Reservoir, and Liwaichanglongshan-Linjiatang, and its lithology is mainly (quartz) monzonitic porphyry, dacite-porphyrite, and rhyolitic porphyry.

\section{1. (Quartz) monzonitic porphyry}

It is mainly distributed at Shexi Village Canyon Tianpingshan mountain top-Dongling, and the east peak of Tianhuangping Reservoir. Rocks are light pink and pink, of porphyritic texture and massive structure; phenocryst is mainly K-feldspar (5-10\%), plagioclase (3-6\%), and quartz (2-3\%). $\mathrm{K}$-feldspar is light pink, in the shape of strips, in the size of 4 $10 \times 3-5 \mathrm{~mm}(3-4 \%)$, and $10-20 \times 5-10 \mathrm{~mm}$ for a few $(1 \%)$, and it is seen that a handful of K-feldspar wraps plagioclase's growth margin; plagioclase is light green, developed epidotization, in the size of $2-10 \times 2-5 \mathrm{~mm}$; quartz is colorless and transparent, in the size of 1-5 mm, granular, and cataclastic but spliceable. Matrix is mostly gray and gray green, in felsitic-micro-granular shape, mainly alkaline feldspar and quartz microcrystalline, in the grain size of $0.1-$ $0.2 \mathrm{~mm}$. Accessory minerals such as zircon and apatite are very little.

\section{Dacite-porphyrite}

It is mainly distributed in Liwaichanglongshan-Linjiatang. Gray green and dark gray, porphyritic texture, phenocryst (10-30\%), unevenly distributed, concentrated speckles locally seen, phenocryst is $0.1-1 \mathrm{~cm}$ in size, mainly milk-white plagioclase (10-20\%), and a handful of augite (4\%) and hornblende (2\%), and a few quartz locally; plagioclase has pretty intact crystal form, in the shape of subhedral plate and column, Na-feldspar bicrystal often seen and annular-belt structure occasionally seen; K-feldspar is in the shape of plate and column, and has Carlsbad twin; quartz mostly in the shape of hexagonal bipyramid, showing cataclastic phenomenon; dark mineral have been fully decomposed into chlorite and carbonate, in the shape of hexagon and rhombus transection, occasionally in the shape of column, which should be hornblende. Matrix is of micro-grained granitic, spherulitic and micro-graphic textures, of which micro-grained granitic texture is mainly $\mathrm{K}$-feldspar and quartz, in the anhedral granular shape, in the 
grain size of $0.05-0.1 \mathrm{~mm}$; spherulitic texture is composed of fiber-like felsic microcrystalline arranged in radial shape or fan, and the center of some is fine feldspar; micro-graphic texture is composed of feldspar and quartz.

\section{Rhyolite (porphyry)}

It is mainly distributed at Tianhuangping Reservoir. Rocks are gray green and brown, of porphyritic texture and rhyolitic structure; phenocryst is mainly light pink K-feldspar (10\%) and a handful of plagioclase (5\%), in the size of $0.5-2 \mathrm{~mm}$. Matrix has developed flow structure with attitude of $300^{\circ} \angle 80^{\circ}$ and $220^{\circ} \angle 20^{\circ}-60^{\circ}$. At the margin, there are a handful of gray-green cryptocrystalline breccia in the size of $5-10 \mathrm{~mm}$, and $10-30 \mathrm{~mm}$ for a few. K-feldspar is in the shape of plate and column, and Carlsbad twin occasionally seen; plagioclase is in the shape of subhedral plate and column, and Na-feldspar bicrystal and concentrated speckle texture seen on some; quartz is in the shape of hexagonal bipyramid, often corroded and irregular; dark minerals have been fully replaced by chlorite and carbonate, its appearance is like column and sheet, which shall be hornblende and biotite, etc. Matrix is of cryptocrystalline felsitic texture, felsitic texture, and micro-graphic texture, etc., mainly cryptocrystalline felsic minerals (K-feldspar and quartz), in the grain size of $0.005-0.05 \mathrm{~mm}$.

\subsubsection{Facies of Volcanic Rocks}

\subsubsection{Division of Volcanic Rock Facies and Their Main Features}

There are a number of previous schemes to divide volcanic rock facies. By referencing "Research Report on Volcanic Structure-Lithology and Lithofacies-Volcanic Strata
Mapping Methods" and "Detailed Rules of Zhejiang on Regional Geological Survey", according to volcanic eruption type, volcanic material transfer way, orientation environment and state, volcanic rocks in the survey area, can be divided into eight main facies: explosive facies (fallout facies, clastic flow facies and surging facies), volcanic debris-flow facies, eruptive sedimentation facies, extrusive overflow facies, eruptive spill facies, explosive spill facies, volcanic vent facies and subvolcanic rock facies, and ten subfacies (Table 3.3).

\section{Explosive Facies}

(1) Fallout accumulative facies

In the survey area, fallout accumulative facies is the most typical in the mid-part of the Member \#1 of Huangjian Formation $\left(\mathrm{K}_{1} h^{1}\right)$ of Shexi Village Canyon, Baofu Town and is the result of sedimentation and accumulation of volcanic debris under gravity after they are carried overhead by explosive airflow and migrated by wind. Lithology is mainly gray purple rhyolitic dacitic breccia(-bearing) crystal-vitric tuff, a handful of breccia crystal pyroclast tuff, breccia-bearing crystal-vitric weak ignimbrite, and locally interbedded with purple tuffite. This suite of rocks has developed better rhythmic beddings (Fig. 3.48), in mediumthick-lamellar structure, and strata vary greatly in thickness, $10-50 \mathrm{~cm}$ thick per layer; breccia is $10-20 \%$ in content, angular-subangular, mainly light pink rhyolite and gray-green ignimbrite, etc., in the grain size of $5-15 \mathrm{~mm}$; crystal pyroclast is $15-25 \%$ in content, mainly $\mathrm{K}-$ Na-feldspar (10-18\%), plagioclase (5-7\%), and a handful of biotite, in the grain size of $2-3 \mathrm{~mm}$; in this area, the attitude of strata is $45^{\circ} \angle 15^{\circ}$ at the lower part, and the content of breccia and crystal pyroclast becomes less

Table 3.3 Volcanic rock lithology and lithofacies division in the survey area

\begin{tabular}{|c|c|c|c|}
\hline \multirow{2}{*}{$\begin{array}{l}\text { Stratigraphic unit } \\
\text { Huangjian } \\
\text { Formation }\left(\mathrm{K}_{1} h\right)\end{array}$} & \multicolumn{2}{|c|}{ Lithofacies } & \multirow{2}{*}{$\begin{array}{l}\text { Lithology } \\
\text { Rhyolitic/dacitic (bearing-) crystal-vitric tuff, breccia (-bearing) crystal-vitric tuff, and breccia(- } \\
\text { bearing) crystal pyroclast tuff }\end{array}$} \\
\hline & \multirow[t]{3}{*}{$\begin{array}{l}\text { Explosive } \\
\text { facies }\end{array}$} & $\begin{array}{l}\text { Fallout } \\
\text { facies }\end{array}$ & \\
\hline & & $\begin{array}{l}\text { Clastic } \\
\text { flow facies }\end{array}$ & $\begin{array}{l}\text { Rhyolitic/dacitic crystal-vitric ignimbrite, breccia(-bearing) crystal-vitric ignimbrite, breccia(- } \\
\text { bearing) vitric ignimbrite, breccia(-bearing) crystal pyroclast ignimbrite, and debris ignimbrite }\end{array}$ \\
\hline & & $\begin{array}{l}\text { Surging } \\
\text { facies }\end{array}$ & $\begin{array}{l}\text { Its lower part is interbedding of rhyolitic crystal pyroclast tuff and tuffaceous sandstone, and its } \\
\text { upper part is rhyolitic crystal pyroclast tuff }\end{array}$ \\
\hline & \multicolumn{2}{|c|}{$\begin{array}{l}\text { Volcanic debris-flow } \\
\text { facies }\end{array}$} & $\begin{array}{l}\text { Thick-lamellar-massive rhyolitic agglomerate breccia tuff, rhyolitic/dacitic agglomerate rock, } \\
\text { agglomerate breccia, and breccia }\end{array}$ \\
\hline & \multicolumn{2}{|c|}{$\begin{array}{l}\text { Eruptive sedimentary } \\
\text { facies }\end{array}$} & Tuffaceous glutenite, tuffaceous gravel-bearing sandstone, tuffaceous sandstone, and tuffite \\
\hline & \multicolumn{2}{|c|}{ Extrusive overflow facies } & $\begin{array}{l}\text { Vitric (breccia-bearing)rhyolitic porphyry, felsitic massive rhyolitic porphyry, and felsitic } \\
\text { massive nevadite }\end{array}$ \\
\hline & \multicolumn{2}{|c|}{ Eruptive spill facies } & Bubble rhyolite (porphyre) and fluidal rhyolite (porphyre) \\
\hline & \multicolumn{2}{|c|}{ Explosive spill facies } & Rhyolitic tuff lava \\
\hline & \multicolumn{2}{|c|}{ Volcanic vent facies } & Agglomerate breccia lava \\
\hline & \multicolumn{2}{|c|}{ Subvolcanic rock facies } & Monzonitic porphyry, granite porphyry, diorite porphyry, and dacite-porphyrite \\
\hline
\end{tabular}


Fig. 3.48 Thin-medium-layered dacitic tuff in the mid-part of the Member \#1 of Huangjian Formation $\left(\mathrm{K}_{1} h^{1}\right)$, Nanwu Forest Farm, Zhangcun
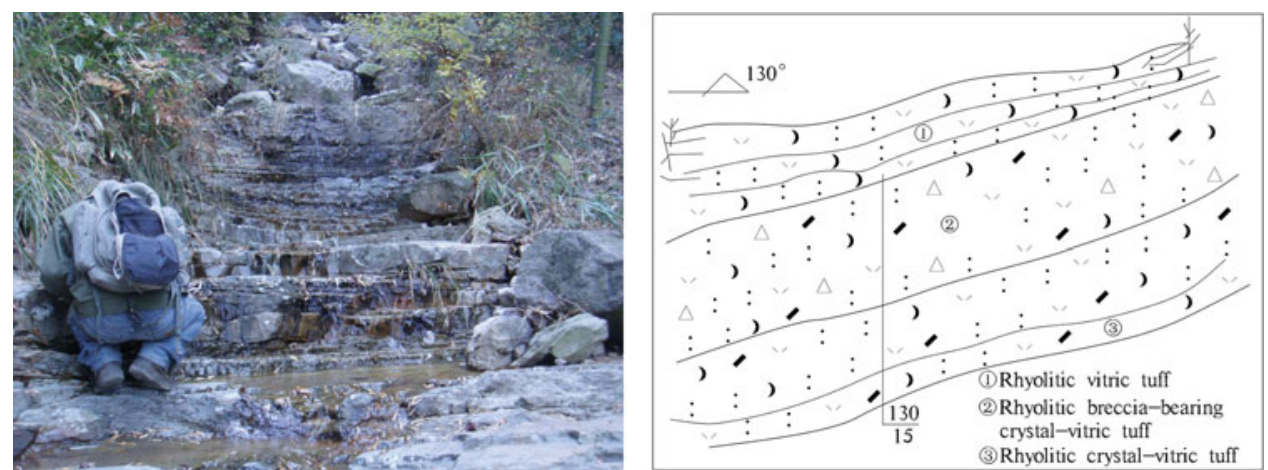

gradually upward, but increases locally, the attitude becomes $195^{\circ} \angle 27^{\circ}$ and the stratum attitude is gentle in general.

\section{(2) Debris-flow accumulative facies}

In the survey area, the debris-flow accumulative facies mainly developed in the lower part of the Member \#1 of Huangjian Formation $\left(\mathrm{K}_{1} h^{1}\right)$ and its Member \#2 $\left(\mathrm{K}_{1} h^{2}\right)$ at Baofu Town and Zhangcun Town, and the Member \#3 of Huangjian Formation $\left(\mathrm{K}_{1} h^{3}\right)$ at Tianhuangping, where volcanic debris with small kinetic energy mainly move in the form of stratified flow in the process of plumed moving outward. Lithology is mainly a suite of rhyolitic dacitic breccia-bearing crystal-vitric ignimbrite and vitric ignimbrite, etc., at different clinkering degrees. Plastic vitric and magmatic fragments are widely developed in rocks, the feature of plastic deformation is very clear so as to form pseu-flowage structure (Fig. 3.49), and it is often seen that pseu-flowage structures flow around crystal pyroclast and breccia, and fold-like quasi-rhyolitic structures are seen locally, indicating the ancient flow direction of debris flow.

With the stable thickness and mostly massive structure, strata in these areas have developed hexagonal, pentagonal, and quadrangular columnar joints and massive joints (e.g., the peak of East Tianmu Mount Scenic Area). Where volcanic debris-flow cooling unit or flow unit is completely developed, their facies sequence structures are: the lower part is rocks of surging accumulative facies (In the survey area, it is only seen at Xikou, Lin'an District, as mentioned below), the mid-part is rock of debris-flow accumulative facies (ignimbrite), and the upper part is rocks of fallout accumulative facies, the debris-flow accumulative facies is in gradually transitional relationship with the surging accumulative facies while in abrupt change relationship with the fallout accumulative facies with clear borderlines (e.g., Shenxi Canyon).

\section{(3) Surging accumulative facies}

In the survey area, the surging accumulative facies is only seen at Xikou Village, Lin'an District, with outcropping locally, in which volcanic debris mainly move in beddy or turbulent form in plume and is not fully homogenized in the cloud formation and consumes energy lightly faster, which is the front of dense, high-concentration volcanic debris flow, one of the sequences of ignimbrite flow units and is in gradually transitional relationship with rhyolitic ignimbrite of the debris-flow accumulative facies.

For this suite of rocks, its lower part is interbeddings of medium-thick-layered light gray rhyolitic crystal pyroclast tuff and dark gray tuffaceous siltstone, gradually transitioned to be offwhite tuffaceous sandstone upwards, and it has wedge-shaped staggered bedding, wavy bedding, oblique bedding, and horizontal bedding, etc., and the borderline for each stratum is irregular (Fig. 3.50). It is in gradually transitional relationship with its overlying rhyolitic crystal pyroclast ignimbrite (debris-flow accumulative facies).

Rhyolitic crystal pyroclast tuff, light gray, tuffaceous texture, and medium-thick-layered structure. Crystal pyroclast is mainly light pink K-feldspar (15-20\%), colorless transparent quartz (15\%), plagioclase (10\%), and a handful of biotite $(5 \%)$, all in the grain size of $0.5-1.5 \mathrm{~mm}$, where the latter developed chlorite alteration; rocks contain a handful of dark green breccia (1-2\%). Rocks vary greatly in thickness, about 8-70 $\mathrm{cm}$ thick per layer. A single layer has developed reverse and normal graded bedding structures (Fig. 3.51), interlined with dark gray ignimbrite $(1-2 \mathrm{~cm})$ locally.

Tuffaceous siltstone, dark gray, tuffaceous silty texture, and medium-thick-lamellar structure, about $5-40 \mathrm{~cm}$ thick per layer; mainly composed of normal sediments and volcanic debris, argillaceous and volcanic ash cements. Normal sediments are $55-60 \%$ in content mainly silty and argillaceous, etc. The silty is finer $(0.03-0.05 \mathrm{~mm})$ and contains feldspar and quartz, not evenly distributed, more at local places. The volcanic debris is $40-45 \%$ in content, mainly vitric fragment, a handful of crystal pyroclast and volcanic ash, etc. Inside a single layer, normal graded bedding structure is developed, and grain size is transitional gradually.

Tuffaceous sandstone, offwhite, mainly sand grains, and argillaceous, etc. Sand is in the angular shape and in the 

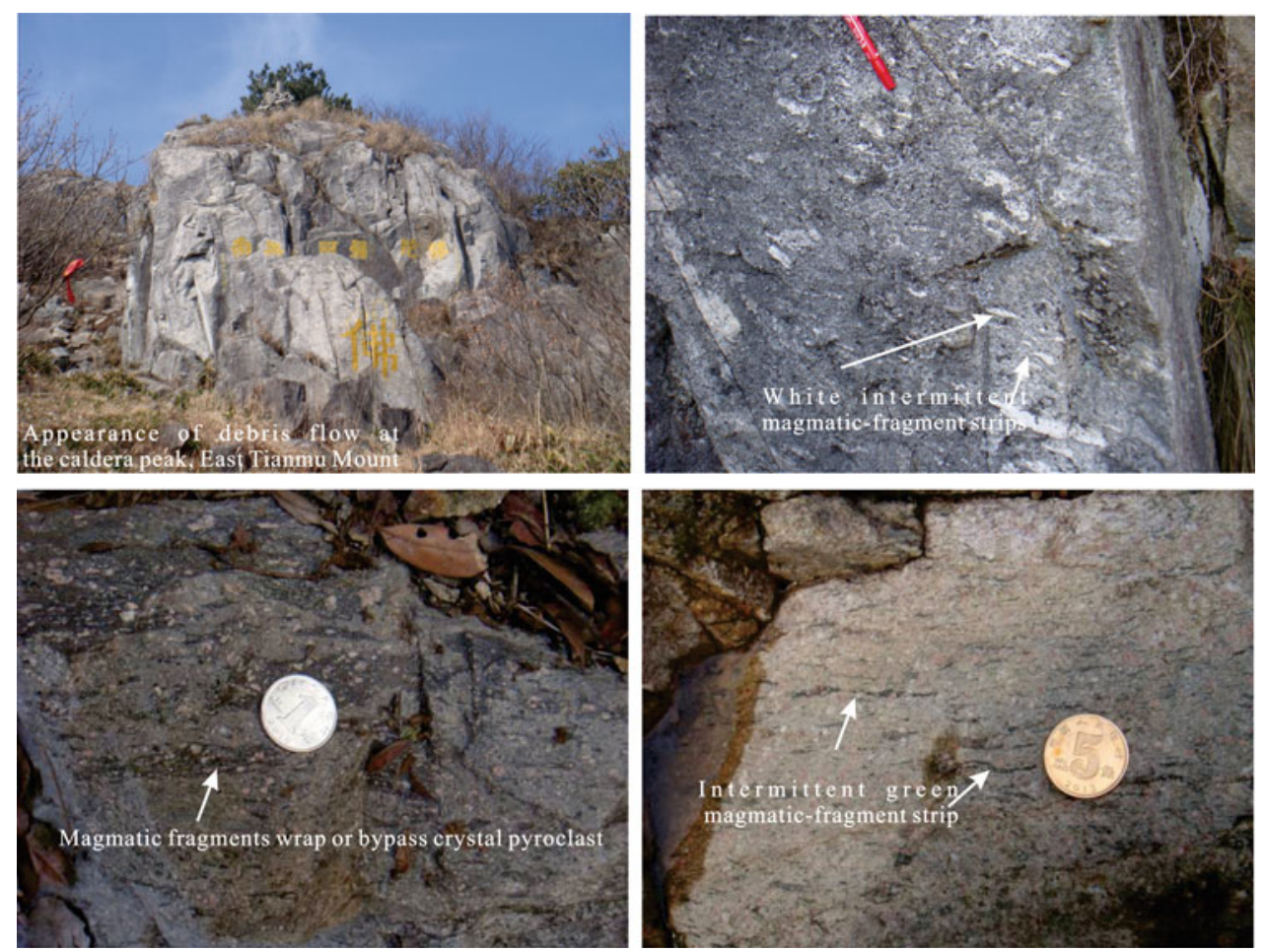

Fig. 3.49 1. Dacitic breccia-bearing crystal-vitric strong ignimbrite of the Member \#3 of Huangian Formation $\left(\mathrm{K}_{1} h^{3}\right)$ at the peak of East Tianmu Mount. 2. Dacitic tuff crystal-vitric strong ignimbrite in the lower part of the Member \#1 of Huangjian Formation $\left(\mathrm{K}_{1} h^{1}\right) .3$ and 4.

Rhyolitic magmatic-fragment crystal-vitric strong ignimbritein the lower part of the Member \#2 of Huangjian Formation $\left(\mathrm{K}_{1} h^{2}\right)$, Shenxi Canyon, Baofu Town

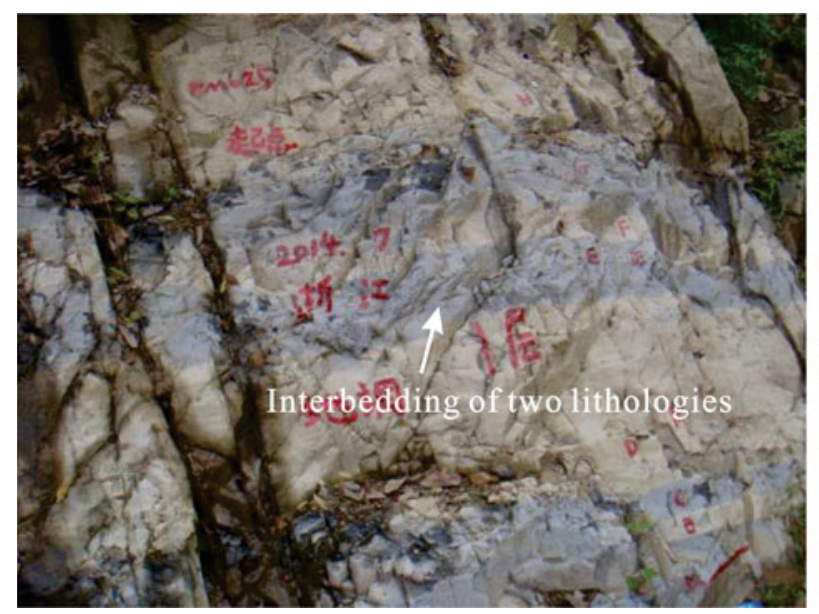

Fig. 3.50 Lower part at Xikou Village, Lin'an District, is interbedding of medium-thick-layered light gray rhyolitic crystal pyroclast tuff and dark gray tuffaceous siltstone (upward, gradually become offwhite
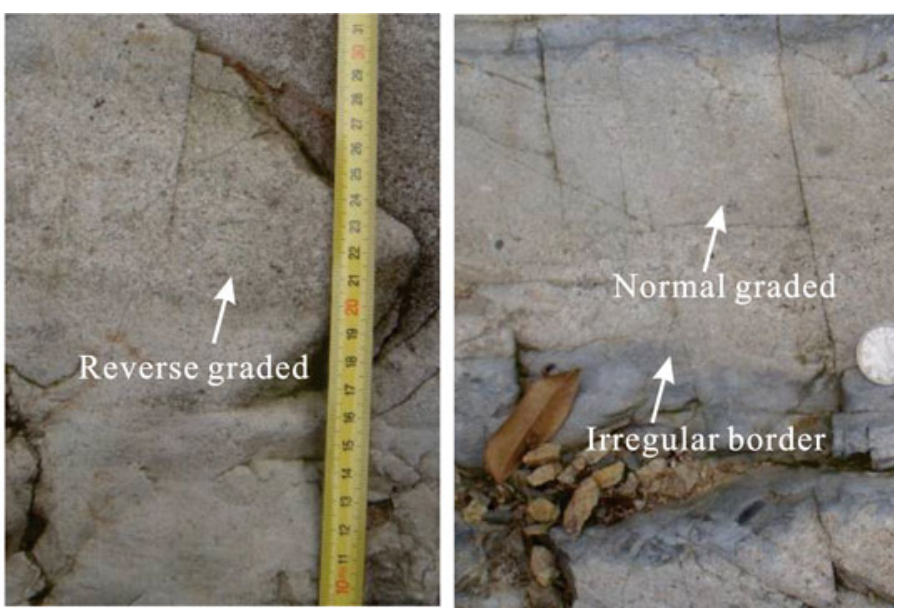

tuffaceous sandstone, and rhyolitic crystal pyroclast tuff in a single layer has developed reverse and normal graded)

pyroclast and volcanic ash, etc. Based on analysis on debris, such rocks experienced short movement and are very likely to accumulation at near places. grain size of $0.1-0.2 \mathrm{~mm}$, mainly feldspar and quartz, etc. The volcanic debris is less than normal sediments in content, about $40 \%$, mainly vitric fragment, a handful of crystal 


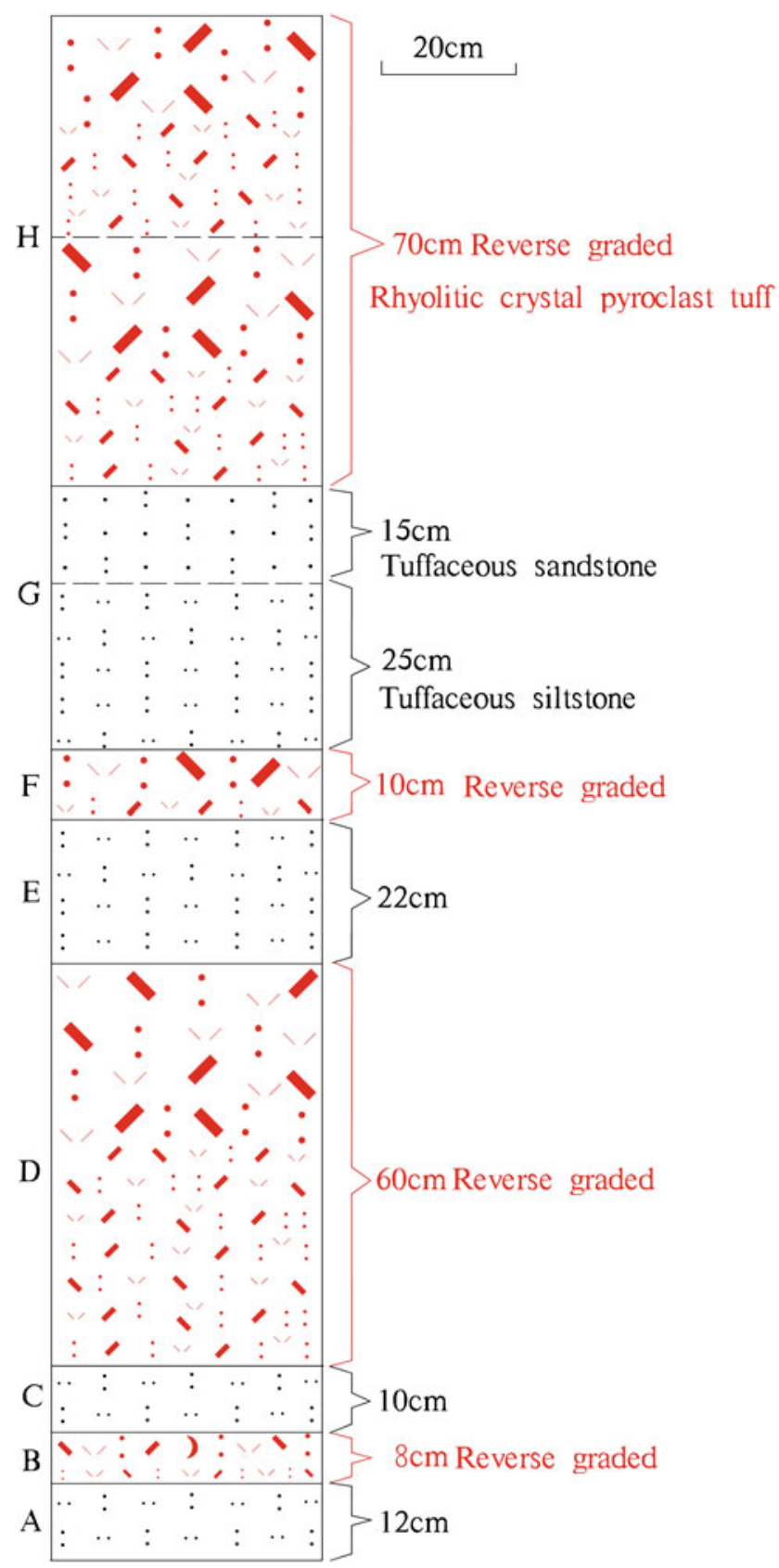

Fig. 3.51 Grade change of volcanic rocks of Surging facies at Xikou, Lin'an

For the surging facies at Xikou Village, Lin'an, the ratio of interbedding of both lithologies in the lower is $6: 4$, the contact surface is slightly wave, in general, the stratum at the lower is thicker and the one at the upper gets thinner; parallel bedding developed at the upper and oblique bedding at the lower; stratum's attitude is $62^{\circ} \angle 42^{\circ}$.

\section{Volcanic debris-flow accumulative facies}

In the survey area, the volcanic debris-flow accumulative facies is only developed in the lower part of the Member \#2 Huangjian Formation $\left(\mathrm{K}_{1} h^{2}\right)$ at East Tianmu Mount Scenic Area, in fault contact with the Member \#3 Xiyangshan Formation $\left(\mathrm{CO} x^{3}\right)$, produced by coarse-graded breccia, agglomerate and rock blocks quickly falling and accumulative near crater under gravity after volcanic debris were brought overhead by explosive gas; however, possibly under action of ephemeral drainage concurrent with volcanic eruption, these volcanic explosive accumulations move volcanic products down along the volcanic slope to form accumulation of volcanic debris-flow facies; its sediment in the lower part is thick-lamellar-massive rhyolitic agglomerate(-bearing) breccia, becomes rhyolitic agglomerate-bearing breccia tuff and tuffaceous gravel-bearing sandstone upward, locally interbedded with thin-lamellar tuffite and tuffaceous siltstone. Features of the suite of rocks are as follows.

(1) Volcanic debris varies greatly in size, volcanic ash coexists with agglomerate, in general, since debris-flow accumulation there is a certain sorting from bottom to top but the sorting is poor in a single stratum.

(2) Agglomerate and breccia had been partly rounded in the transfer process, angular agglomerate coexists with subangular, subrounded, and rounded coarse debris (Fig. 3.52), and on the surface of some agglomerate breccia various impressions due to friction and collision are visible.

(3) Most of the accumulations are volcanic debris and cement is mainly tuffaceous.

\section{Eruptive Sedimentary Facies}

In the survey area, the eruptive sedimentary facies is developed in the top of the Member \#1 of Huangjian Formation $\left(\mathrm{K}_{1} h^{1}\right)$ at Baofu Town-Zhangcun Town, and in the top of the Member \#3 of Huangjian Formation $\left(\mathrm{K}_{1} h^{3}\right)$ at Tianhuangping and Dongkeng Village, etc., which is formed by volcanic eruptive materials falling in water bodies, or being sedimented in water bodies through denudation and transportation, rather continually distributed at the margin of volcanic depression and caldera, or produced in volcanic rock in the form of interbedding, an important part of volcanic depressions or calderas. Sediments are volcanic debris sedimentary rock (tuffaceous glutenite, tuffaceous gravel-bearing sandstone-siltstone, and tuffite) and sedimented volcanic clastic rock (sedimentary breccia tuff), with 
Fig. 3.52 Bottom feature of Huangjian Formation's Member \#2 $\left(\mathrm{K}_{1} h^{2}\right)$ at East Tianmu Mount Scenic Area
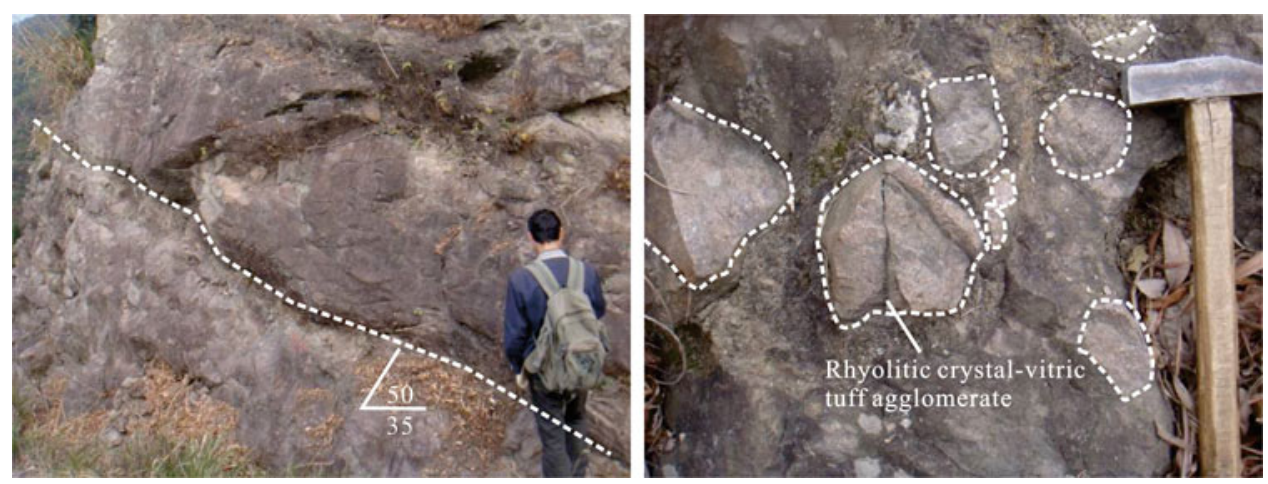

clear horizontal bedding developed (Fig. 3.53). and sedimentary rhythm, and there are interlaced, wavy, and involuted beddings, etc., indicating a turbulent shallow lake facies.

\section{Extrusive overflow facies}

In the survey area, the extrusive overflow facies are mainly developed in the Member \#2 of Huangjian Formation $\left(\mathrm{K}_{1} h^{2}\right)$ in Shengou Village Canyon, Baofu Town, and its lithology is mainly massive rhyolitic porphyry. It is a geological body produced by accumulative and cooling viscous and dense magma that is slowly extruded out of surface along volcanic vent or fractures beside volcanic craters. Usually, its shape is kupola, spine, rock monument, and rock ridge, etc., in different sizes and scales, its occurrence is steep, planarly in the shape of ellipse and round, and often in transitional relationship with rock of the eruptive spill facies.

There exists gradually transitional relationship between various facies zones in the massive rhyolitic porphyry of

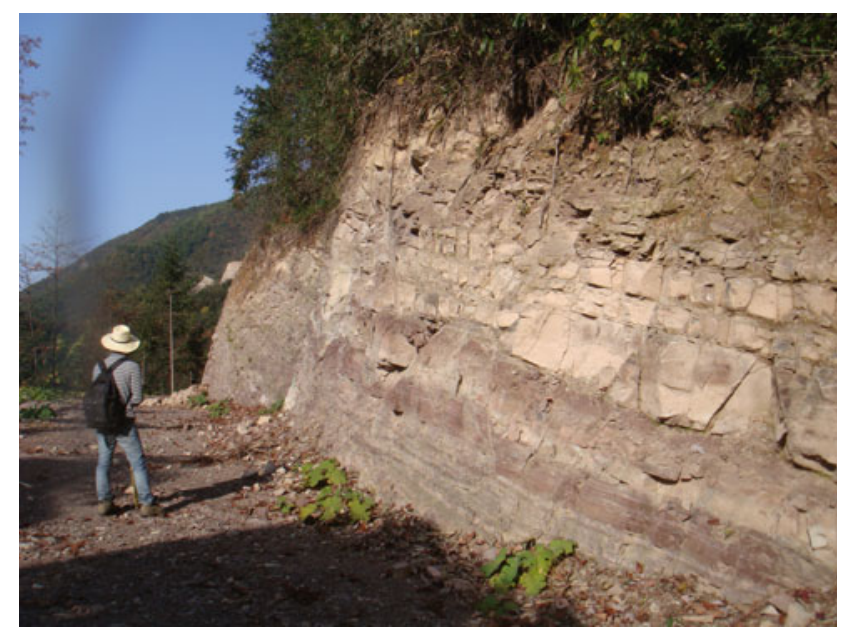

Fig. 3.53 Interbeddings of tuffaceous gravel-bearing packstone and tuffaceous siltstone in the top of the Member \#1 of Huangjian Formation, Nanfu Forest Farm
Shenxi Village Canyon, and the zonation phenomenon is clear. Horizontally, it is divided into vitric (breccia-bearing) massive rhyolitic porphyry at the margin, felsitic massive rhyolitic porphyry in the central and felsitic block nevadite, and meanwhile vein-like intrusion of Early Cretaceous subquartz monzonitic porphyry in the center (Yantianping). The contact relationship between block rhyolitic porphyry and the ignimbrite at the margin is irregular, at some local places steeply dipping vein-like intrusion occurs (see Yangtianping revived caldera for details) and at other local places it dips gently and overlies ignimbrite; affected by later NE-strike fault, it is in fault contact with rhyolitic tuff lava of the magmatic-liquation-type explosive spill facies in the southeastern, and it is presumed that they were in gradually transitional relationship during early eruption stage.

Features of massive rhyolitic porphyry: (1) lithology is single, thick, no interbedding of other volcanic rock or sedimentary rock seen, and no developed rhyolitic structure; (2) the attitude of felsitic nevadite in inner facies zone is steep, with the dip angle of $40^{\circ}-75^{\circ}$ with oblique columnar joints structure developed (Fig. 3.54), and phenocryst content is 40 $60 \%$; (3) the felsitic rhyolitic porphyry of the transitional facies has developed massive joints, phenocryst content is 20 $40 \%$, locally rhyolitic structure indistinctly seen; (4) the vitric rhyolitic porphyry at the margin has developed horizontal plate-columnar joints, with gentle attitude and at the dip angle of $15^{\circ}-30^{\circ}$, more breccia containing similar components are often seen, the border is clear, phenocryst content is $5-20 \%$ and phenocryst has the strong feature of collaging; (5) from central facies zones to transitional and marginal facies zones, phenocryst in rocks becomes more cataclastic, the matrix shows a trend of micro-grained texture-felsitic texture-cryptocrystalline texture; (6) the Early Cretaceous subvolcanic rock-rhyolitic porphyry-rhyolitic tuff lava are closely symbiotic, there were formed basically in the same or similar period, so as to create a symbiotic combined geological body integrating the subvolcanic rock facies, the extrusive overflow facies and the explosive spill facies, indicating they are product of differentiation evolution of comagma. 
Fig. 3.54 Feature of massive rhyolitic porphyry at Shenxi Canyon
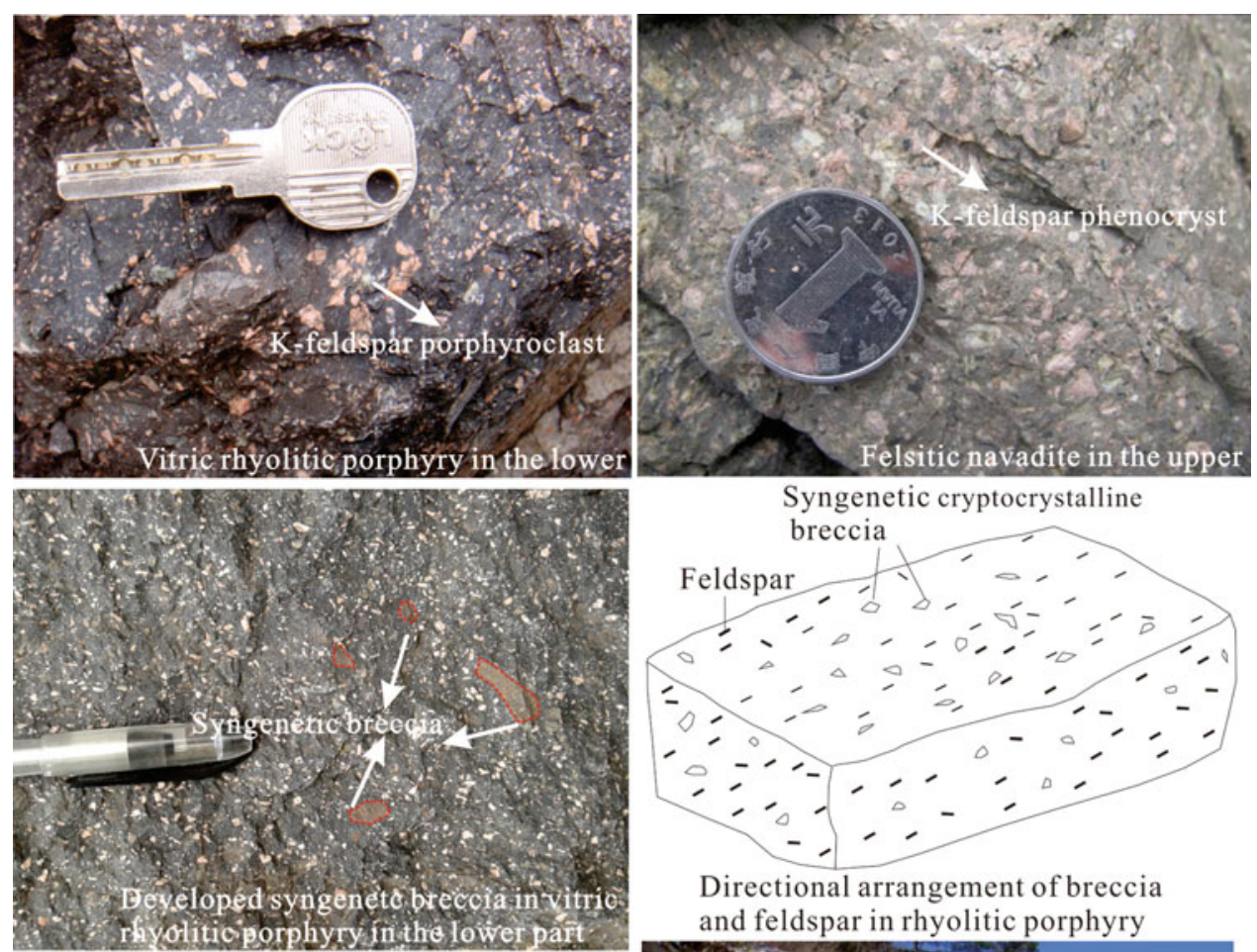

Directional arrangement of breccia and feldspar in rhyolitic porphyry

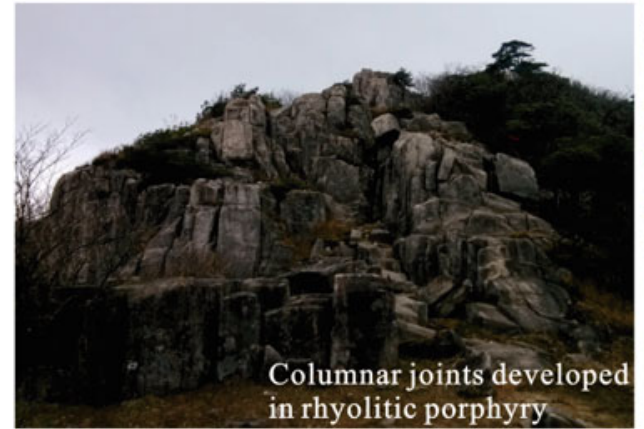

\section{Eruptive spill facies}

In the survey area, the eruptive spill facies is mainly developed in the mid of the Member \#2 of Huangjian Formation $\left(\mathrm{K}_{1} h^{2}\right)$ of South Tianmu Mount and Member \#4 $\left(\mathrm{K}_{1} h^{4}\right)$ of West Tianmu Mount-Longwangshan and North Tianmu Mount-Shifosi, which is lava of various types produced by later magma ascent from the deep underground via the volcanic vent to the earth surface and then spilling out of the crater. In the survey area, lithology is mainly porphyritic rhyolite and bubble rhyolite, one of the main rocks in dome-shaped volcanos, and rhyolitic structure is very developed, in West Tianmu Mount Scenic Area, there are often wrinkle-shaped rhyolitic structures (Fig. 3.55), and it also has developed bedding joints, columnar joints in the shape of embossment are developed at local places, rocks at the margin have developed bubble structure and slightly less phenocryst, and rocks in the mid has less bubble but more phenocryst. Surrounding Shifo Temple area, possibly since magma contains more volatile matters, bubble is very developed in rocks at the lateral of volcanic craters, and often seen concentratively distributed in layers.

\section{Explosive spill facies}

In the survey area, the explosive spill facies is mainly distributed in the upper part of Member \#2 of Huangjian Formation $\left(\mathrm{K}_{1} h^{2}\right)$ of Gaoling Village-Dongkeng VillageShuitaozhuang Village, Lin'an District, a transitional lithofacies due to eruption of volcanos in the form of boiling spill (between intensive explosion and quiet spray and spill), composed of volcanic debris and lava matrix, in overlying/underlying or fault contact relationship with the eruptive spill facies's porphyritic rhyolite in the mid and lower part of Member \#2 of Huangjian Formation $\left(\mathrm{K}_{1} h^{2}\right)$. 

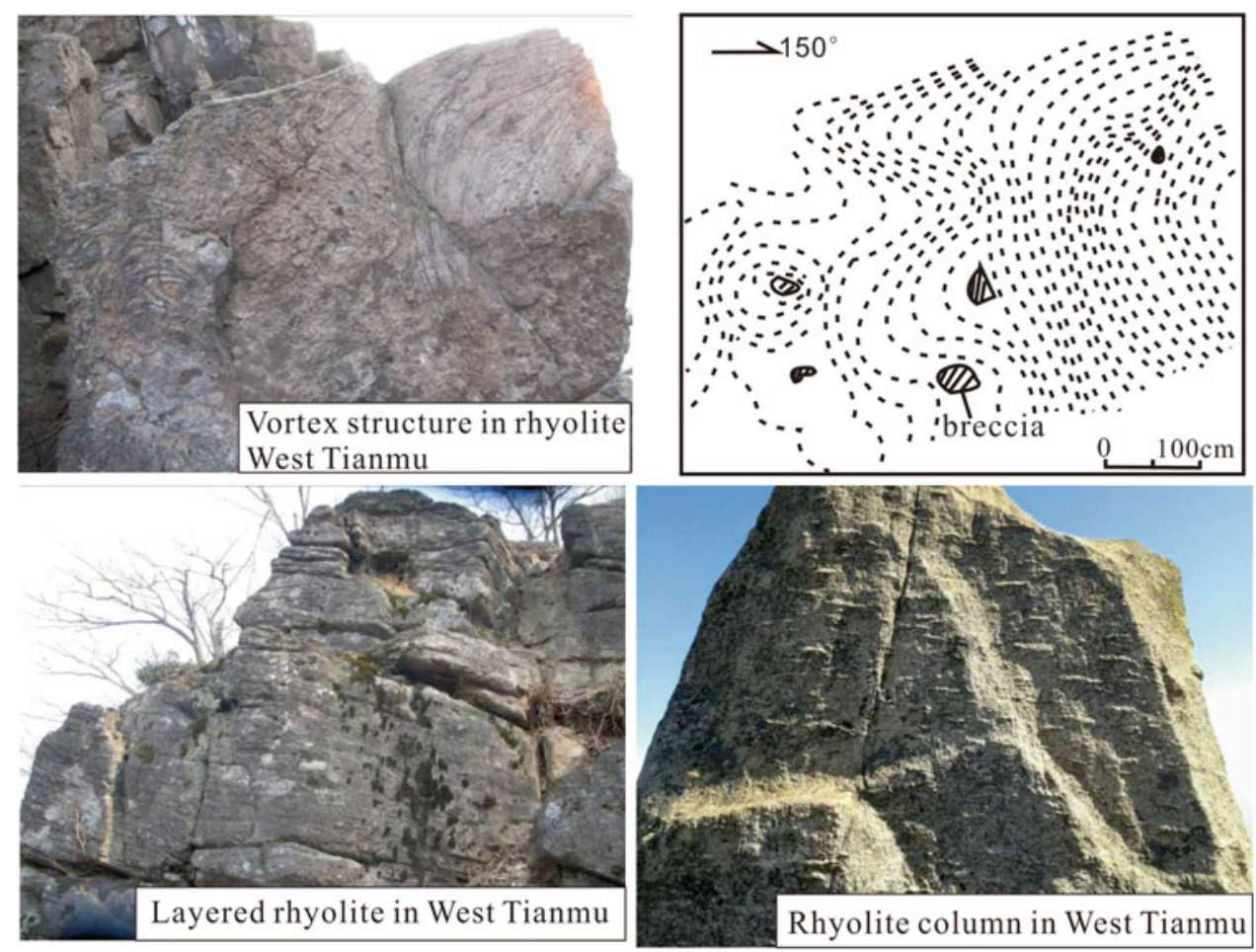

Fig. 3.55 Porphyritic rhyolite in West Tiannu Mount-Longwangshan
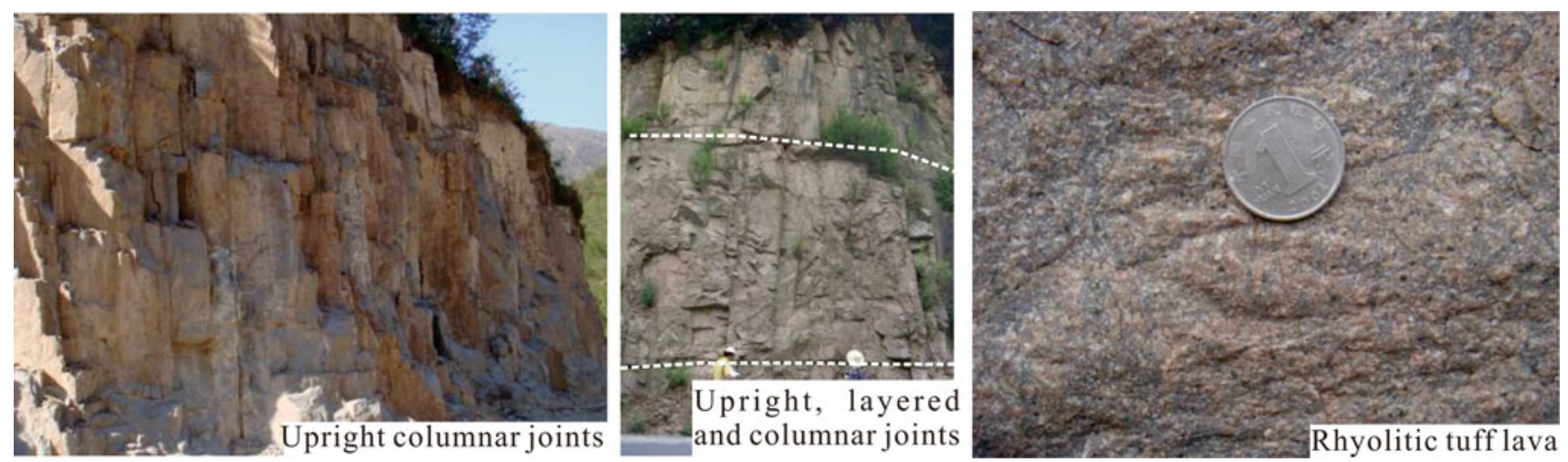

Fig. 3.56 Rhyolitic tuff lava at Dongkeng Village, West Tianmu Mount, Lin'an District

Lithology is mainly rhyolitic (crystal pyroclast) tuff lava, its main difference from porphyritic rhyolite is: the former has no developed flow structure, but massive structure, with developed columnar joints (Fig. 3.56), in medium-fine-grained (quasi-porphyritic) texture, crystal pyroclast is high in content (30-70\%) and matrix is felsitic-micro-grained; the latter has developed both flow structure and columnar joints, but mostly in sheet shape, porphyritic texture, with low phenocryst (5$20 \%$ ), and matrix is cryptocrystalline.

\section{Subvolcanic rock facies}

The subvolcanic rock, very developed in the survey area, is mainly located in the center or surrounding caldera, a ultra-hypabyssal-hypabyssal intrusive body sharing the same source, the same time and the same space with volcanic rock, and it does not outcrop the surface but is located at the subsurface. Lithology is mainly quartz monzonitic porphyry and rhyolitic porphyry, most of them occur like 


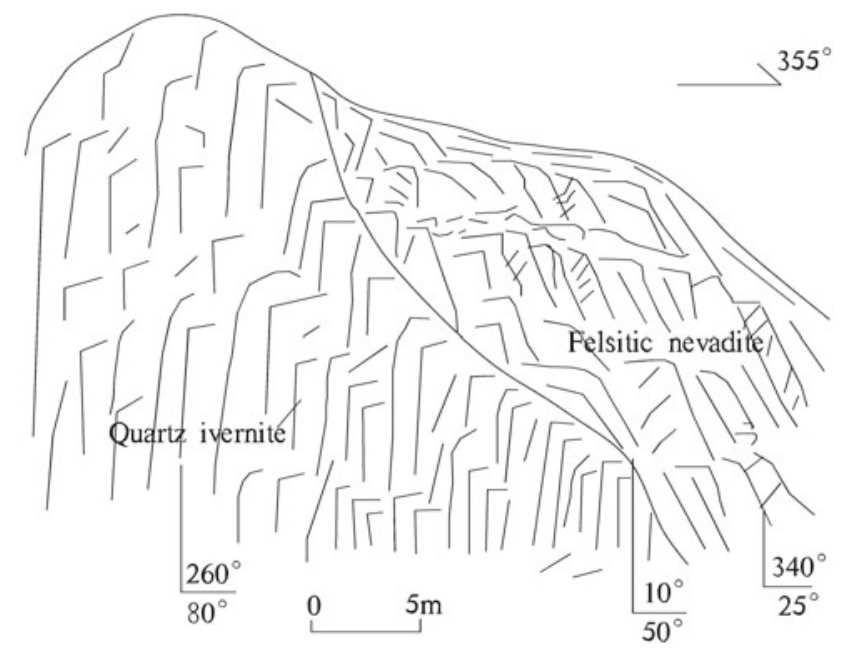

Fig. 3.57 Intrusive features of quartz monzonitic porphyry at Yangtianping

apophysis or boss, in the size of $1-20 \mathrm{~km}^{2}$, for instance, the quartz monzonitic porphyry (Fig. 3.57) at Yangtianping caldera outcrops out of the center of the caldera, in irregular ellipse of which the long and short axes are 7 and $2 \mathrm{~km}$, and it pulsed intruded into felsitic massive nevadite.

It is often filled in radial and annular fracture or fissures between strata, minerals in rocks are complex and many agglomerate breccias such as andesite wrapped inside.

\subsubsection{Combination of Volcanic Facies}

Combination of volcanic facies is the volcanic facies generated during one eruption in the history of a volcano and its generation sequence, and the type of combination of volcanic facies reflects comprehensively the features and rules of volcanic activities. There are temporal sequences and spatial superimposition relationships in lithofacies produced from multiple eruptions, research on combination types of volcanic facies help identify the source and direction of volcanic matters, determine the location of volcanic vent or volcanic eruption center, and restore the type and activity history of ancient volcanos. According to research on volcanic facies in the survey area, there are mainly three types of basic combinations as below.

\section{Explosive facies series (debris-flow accumulative facies-fallout accumulative facies)-eruptive sedimen- tary facies combination}

It is mainly seen at (the lower part) of Yangtianping revived caldera and Tianhuangping caldera, a common type of volcanic facies combinations in the survey area, reflecting that intense eruption and dormancy occur alternately during volcanic action, representing the mutual accumulation relationship between volcanic clastic facies and sedimentary facies. For instance, intense volcanic eruption occurs in the

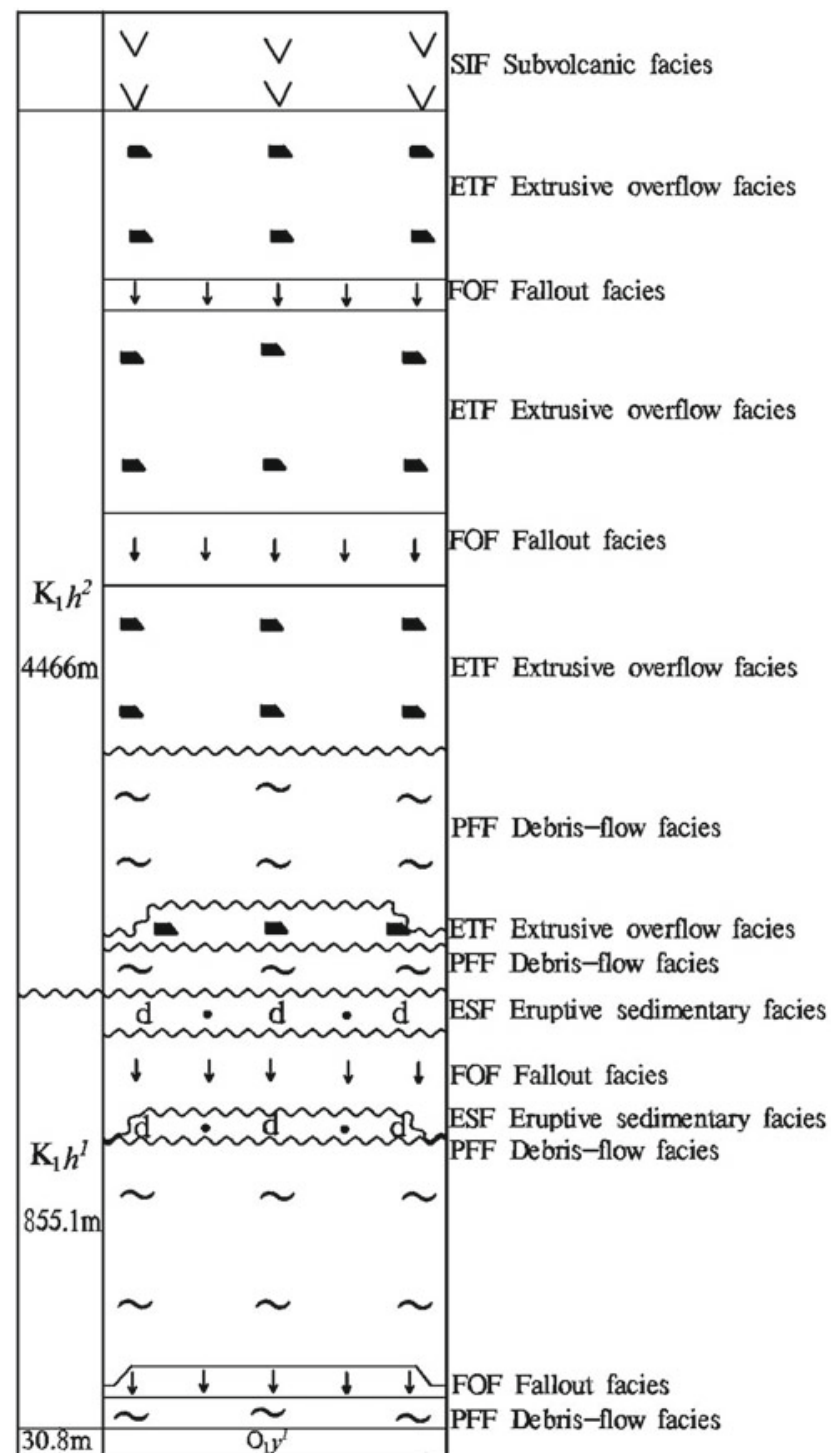

Fig. 3.58 Lithofacies combination in the lower of Yangtianping revived caldera

early of Yangtianping revived caldera led to formation of debris-flow accumulative facies-fallout facies of the explosive facies series, and sedimentary facies erupted locally; after that the crater collapsed to form a caldera lake where a set of stable volcanic-debris-rich sedimentary rocks with a certain thickness was deposited (Fig. 3.58).

\section{Explosive facies series (debris-flow accumulative facies-fallout accumulative facies)-extrusive overflow facies combination}

This series combination is mainly developed at (the upper of) Yangtianping revived caldera which, after collapse and sedimentation from early eruption, began reviving and erupting. Firstly, it erupted intensely for a very short time to 


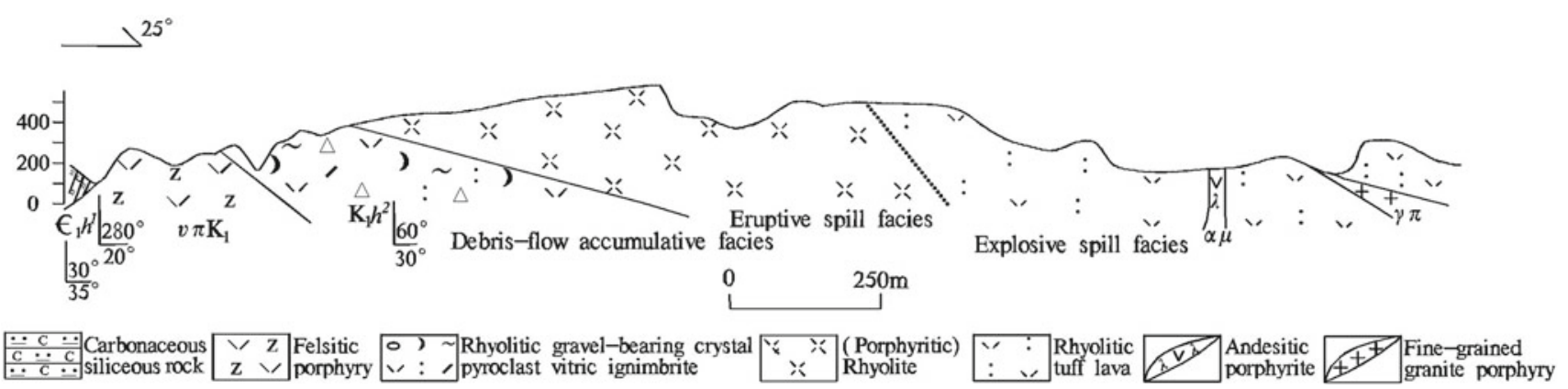

Fig. 3.59 Combination of debris-flow accumulative facies-eruptive spill facies-explosive spill facies in the Member \#2 of Huangjian Formation in the western of East Tianmu Mount

form a set of rocks of debris-flow accumulative facies-fallout accumulative facies, which is not table in thickness, thick at some local places (e.g., Changtanqiao), and thin at others (e.g., Shexi Village Canyon); secondly, the volcano erupted at a weak intensity and experienced extrusion and overflow in large scale, and finally it became intrusion of subvolcanic rock (Fig. 3.59).

\section{Explosive facies series (surging accumulative debris- flow accumulative facies-fallout accumulative facies)- eruptive spill facies-explosive spill facies combination}

It is mainly seen at East Tianmu Mount, Xikou Village, and Dongkeng Village, etc., also one of the important volcanic facies combinations in the survey area, and commonly seen in revived caldera (East Tianmu Mount-Caotanggang) and dome-shaped volcanos (South Tianmu Mount). East Tianmu Mount-Caotanggang revived caldera contains volcanic clastic rock of the explosive facies in its lower, porphyritic rhyolite (bubble rhyolite) of the eruptive spill facies in the mid and rhyolitic tuff lava of the explosive spill facies in the upper, reflecting that volcanic action changes from intense eruption in the early and quiet eruptive spill and explosive spill in the late (Fig. 3.60).

\subsubsection{Volcanic Eruption Rhythms and Cycles}

\subsubsection{Volcanic Eruption Rhythm}

Volcanic eruption rhythm means the cyclical changes of volcanic eruption, and such cyclical changes include regular changes in erupted material components, eruption intensity, eruption ways, and erupted thickness, etc. Generally speaking, a rhythm is composed of a or a few layers of rocks some of which could be very thin, just dozens of centimeters while others may be very thick, about hundreds of meters.

Based on volcanic eruption from strong to weak and its eruption ways, in the survey area, the Huangjian Formation volcanic rocks may be divided into four eruption rhythms (Fig. 3.61).

Eruption rhythm \#1 is mainly the evolution of the debris-flow accumulative facies (locally interbedded with erupted sedimentary facies) $\rightarrow$ the fallout accumulative facies $\rightarrow$ the eruptive sedimentary facies, with the total thickness of $>855 \mathrm{~m}$, mainly distributed along Zhangcun Town in the survey area.

Eruption rhythm \#2 is mainly evolutions of the volcanic debris-flow facies and the surging accumulative facies (local) $\rightarrow$ the debris-flow accumulative facies $\rightarrow$ the extrusive overflow facies $\rightarrow$ the eruptive spill facies $\rightarrow$ the explosive

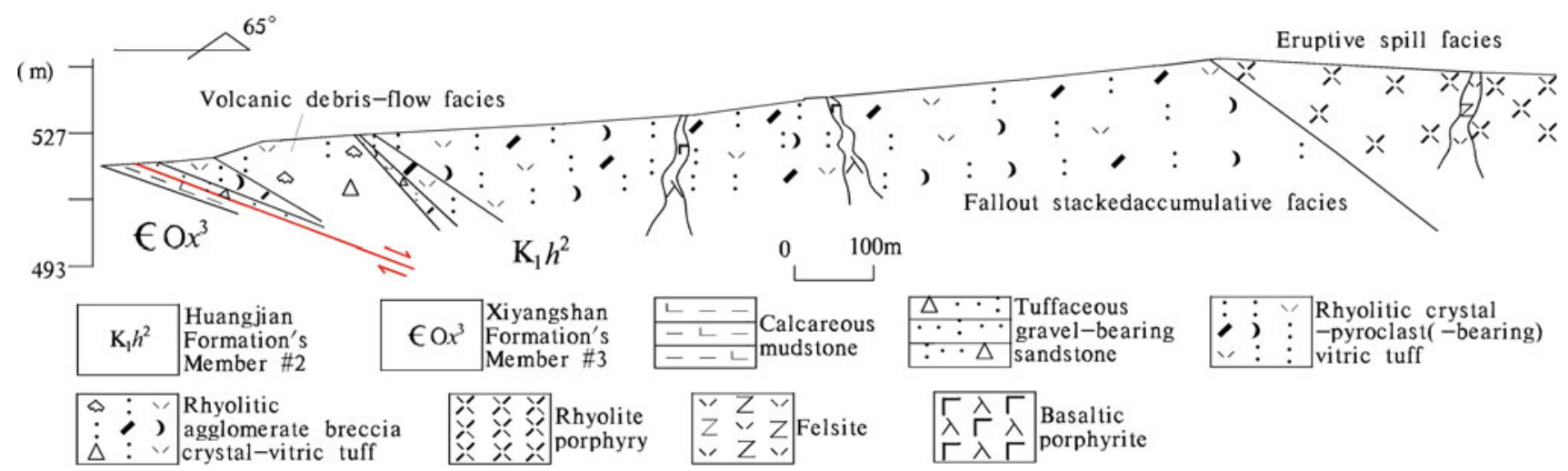

Fig. 3.60 Combination of volcanic debris-flow facies-fallout accumulative facies-eruptive spill facies in Huangjian Formation's Member \#2 of Tianmu Mount Scenic Area 

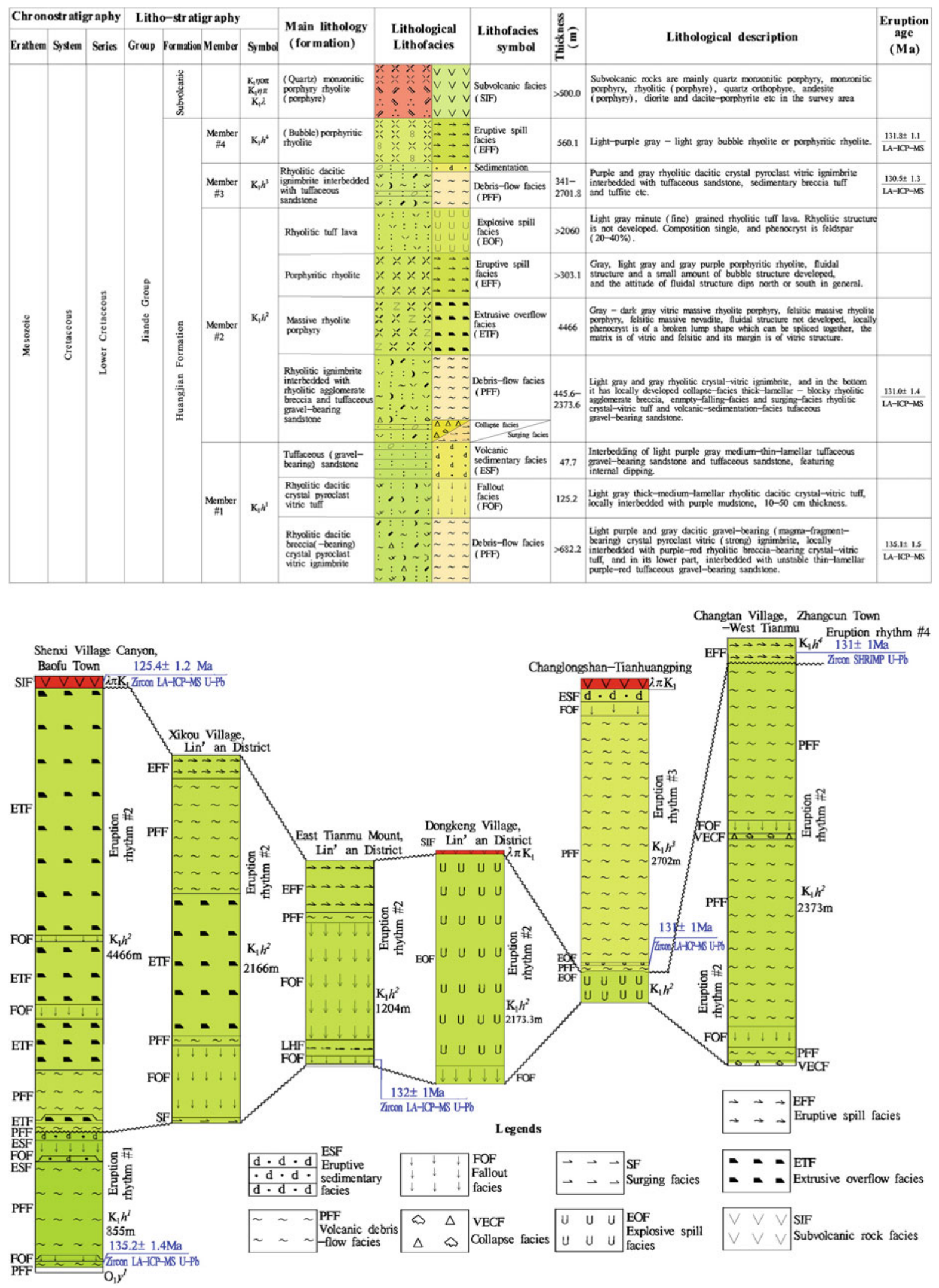

Fig. 3.61 Overall histogram on volcanic eruption rhythm and lithofacies formation in the survey area 
spill facies $\rightarrow$ the subvolcanic rock facies, with total thickness of 7274-9202 m, an important part of volcanic rocks in the survey area. The combination of main rhythmic lithofacies varies in different areas, of these the Baofu TownZhangcun Town is mainly the evolution of the debris-flow accumulative facies $\rightarrow$ the extrusive overflow facies $\rightarrow$ the subvolcanic facies, the East Tianmu Mount is evolution of the volcanic debris-flow facies $\rightarrow$ the debris-flow accumulative facies $\rightarrow$ the eruptive spill facies $\rightarrow$ the explosive spill facies $\rightarrow$ the subvolcanic facies while Xikou Village is evolution of the surging accumulative facies $\rightarrow$ the debris-flow accumulative facies $\rightarrow$ the eruptive spill facies $\rightarrow$ the explosive spill facies.

Eruption rhythm \#3 is mainly evolution of the debris-flow accumulative facies (locally interbedded with the eruption sedimentary facies) $\rightarrow$ the eruptive sedimentary facies $\rightarrow$ the subvolcanic facies, mainly developed in the north Tianhuangping-Linjiatang of the survey area, with the total thickness of $>341-2701 \mathrm{~m}$.

Eruption rhythm \#4, prettily single, mainly composed of the porphyritic rhyolite and bubble rhyolite in eruptive spill facies, is mainly developed at West Tianmu Mount-Longwangshan and South Tianmu Mount of the survey area, with total thickness $>500 \mathrm{~m}$.

\subsubsection{Volcanic Eruption Time Limits and Cycles}

\section{Time limit for eruption}

In order to limit the age of volcanic eruption, in the survey area, its top, bottom, and important volcanic rocks are analyzed for LA-ICP-MS zircon U-Pb chronology. In the survey area, in volcanic rocks, zircon mostly is irregular long strip, with the length of 100-150, 70-100, and 150-200 $\mu \mathrm{m}$ for a few, the length-width ratio is about 2:1, and zircon has developed zonal textures. Zircon in the Member \#1-\#4 of Huangjian Formation and volcanic rock, the $U$ content is $(130-569) \times 10^{-6},(60$ $282) \times 10^{-6},(24-332) \times 10^{-6},(51-381) \times 10^{-6}$, and $(120$ 1447 and 112-1259) $\times 10^{-6}$, respectively, Th content is $(103$ $755) \times 10^{-6}, \quad(10-61) \times 10^{-6}, \quad(3-61) \times 10^{-6}, \quad(7-$ $57) \times 10^{-6}$, and (91-887 and 84-597) $\times 10^{-6}$, respectively, $\mathrm{Th} / \mathrm{U}$ ratio is $0.49-1.41,0.14-0.23,0.12-0.25,0.05-0.23$, (0.59-1.25 and 0.47-1.48), a typical feature of magma zircon. Sample points tested are mostly projected on or near the concordant curve, and ${ }^{206} \mathrm{~Pb} /{ }^{238} \mathrm{U}$ weighted mean age is $135.2 \pm 1.4 \mathrm{Ma} \quad(\mathrm{MSWD}=0.93), \quad 132.1 \pm 1.0 \mathrm{Ma}$ $(\mathrm{MSWD}=1.16), \quad 131 \pm 1.0 \mathrm{Ma} \quad(\mathrm{MSWD}=1.06)$, $131 \pm 1.0 \mathrm{Ma}(\mathrm{MSWD}=0.92), 127 \pm 2.0 \mathrm{Ma}(\mathrm{MSWD}=$ 1.06 ), and $125.4 \pm 1.2 \mathrm{Ma}(\mathrm{MSWD}=1.07$ ), respectively (Fig. 3.62), indicating the time limit for volcanic rock eruption is 135.2-125.4 Ma, the beginning of Early Cretaceous, in the survey area.

\section{Eruption Cycles}

Volcanic cycles are intended to make divisions within a volcanic eruption area or a bigger range, it means formation of different volcanic eruption stages within the activity stage of a volcano and cyclic changes of volcanic products associated with a certain volcanic structures, and generally, there are a few of volcanic apparatus or volcanic groups (eruption basins).

By analyzing comprehensively such factors as features of volcanic activities, features of volcanic rock combinations and discontinuity of volcanic activities, in the survey area, the volcanic activity in Early Cretaceous is just one eruption cycle specifically based on the following evidences:

(1) In the survey area, the Huangjian Formation is the only stratum unit of volcanic rocks which has four eruption rhythms.

(2) Though the volcano erupts in multiple stages for a few times in the survey area, volcanic activities are basically continuous (135.2-125.4 Ma), with no regional structural unconformable surface.

(3) In the survey area, despite non-consistence in volcanic rock types and lithofacies combinations between eruption stages, chemical and geochemical features of the volcanic rocks are prettily similar (as mentioned below).

(4) In the survey area, the volcano acts in the Yianmu Mount-Mogan Mount volcanic depression where the structural environment is unchanged, and spatial distribution landscape and types of volcanic structures are pretty single.

\subsubsection{Volcanic Structures}

The distribution pattern of the Late Mesozoic volcanic rocks in Jixi County-Anji County, an area adjacent to the survey are in Zhejiang and Anhui Province indicates the NE-strike regional fracture plays a controlling role in volcanic activities. In the survey area, volcanic rocks are widely distributed, up to $140 \mathrm{~km}$ in length, the northwest border of the strip shaped Changhua-Tianmu Mount-Mogan Mount volcanic rock zone is under control of the NE-strike Jixi fracture zone and Xuechuan-Huzhou Fault to form a series volcanic eruption areas where plutonic intrusions probably are intermittently distributed (three eruption areas: Changhua, Tianmu Mount, and Mogan Munt), manifesting the relationships between volcanic activities and regional structures.

In the survey area, the main body of volcanic structures is a Tianmu Mount volcanic depression (basin) (Level-IV) in the shape of a normal trapezoid, and its south and north sides are in EW strike or NE strike fault or unconformable contact; 

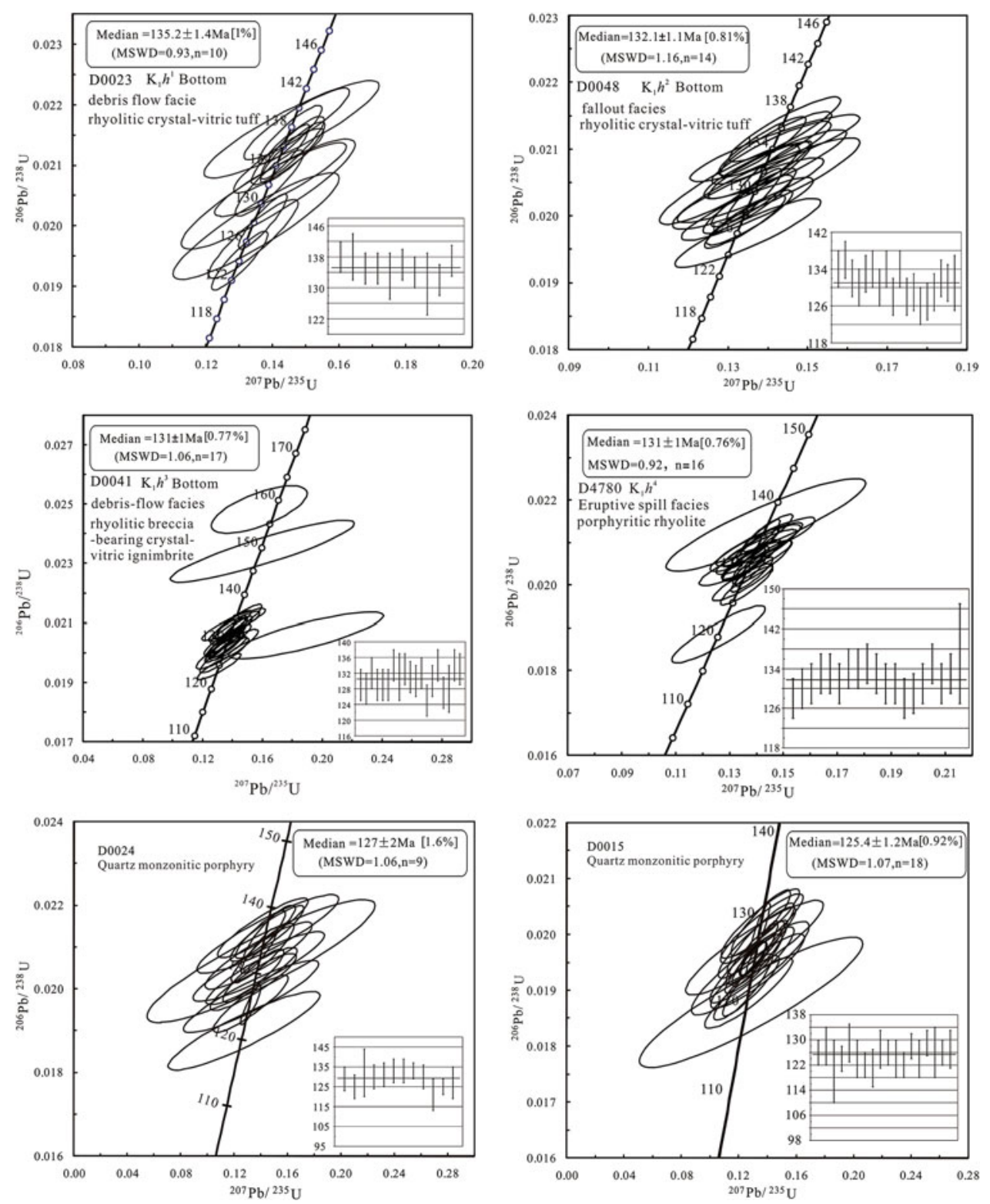

Fig. 3.62 Zircon $\mathrm{U}-\mathrm{Pb}$ concordia diagrams and age histograms for mainly volcanic rocks in the survey area

its west side borders with NE-strike Maotan-Luocun facture and its east side is in fault or intrusive contact with Wushanguan pluton, which is the area accumulation products of Early Cretaceous volcanic activities in the regional fault-depressed structural basin, 30-37 km long from east to west and about $23 \mathrm{~km}$ wide from south to north; its inside developed the eruptive sedimentary rocks, which is intermittently periclinal and dips inward, rock strata are good in stratification, with gentle attitude, for instance at attitude is $95^{\circ}-115^{\circ} \angle 13^{\circ}-15^{\circ}$ for rock strata at Zhangcun Town in the west, $195^{\circ} \angle 27^{\circ}$ for rock strata at Shenxi Village Canyon in the north, and $50^{\circ} \angle 35^{\circ}$ for rock strata at East Tianmu in the south. The border of the volcanic depression is under control of nearly EW-strike buried faults and the NE-strike fault. The nearly EW-strike buried fault, possibly formed in Caledonian or earlier, mainly dipping southward, constituting the north margin of the volcanic rock basin; a large wide and gentle synclinorium formed in the Early Indosinian, i.e., regionally, buried syncline, forming the beginning shape of the volcanic basin, and forming the NE-strike Maotan-Luocun fault (Xuechuan-Huzhou fault) constituting the west margin of the volcanic basin; lifting occurs in Yanshanian so that the fault early formed at the basin border was activated, and the early syncline depression settled down along the border, and intense volcanic eruption and granite intrusion intruded. 
Volcanic activity inside the volcanic depressions of Tianmu Mount is characterized by central eruption, the secondary volcanic structures are mainly central-type volcanic apparatus (Level V) and can be divided into five (revived) calderas and six dome-shaped volcanos based on eruptive and accumulation features. The calderas are included Yangtianping revived caldera, Tianhuangping, Changlongshan-Linjiatang, East Tianmu Mount-Caotanggang, and Yaotianfan caldera, while the dome-shaped volcanoes are included West Tianmu Mount-Longwangshan, South Tianmu Mount, Nanyushan, Shifo Temple, Dashulin, and Wuguishan, with other dome-shaped volcanoes in different sizes. Volcanic structures are characterized by obvious circular structures on 1:50,000 remote-sensing image, e.g., Yangtianping, East Tianmu Mount-Caotanggang, Tianhuangping (revived) caldera, West Tianmu Mount-Longwangshan, South Tianmu Mount, and Nanyushan dome-shaped volcano, with aeromagnetic anomalies developed in central and nearby areas of these volcanoes. All the characteristics of volcanic apparatus are shown in Fig. 3.63.

\subsubsection{1 (Revived) Caldera}

Caldera is a large volcanic apparatus formed after a volcano or a group of volcanoes collapsed, one of the main types of volcanic apparatuses in the survey area. Revived caldera means that after a caldera takes shape there are still volcanic clastic rock and lava erupting out of caldera, but mainly piedmont accumulation, collapsed accumulation at the caldera wall and lacustrine sediments; in some large caldera composed of acidic rocks volcanic activity often recurred to be developed into revived caldera; revived dome left some or all previously sunken fault blocks to uplift and ascent, so that rock strata previously horizontal or dipping inward possibly dip outward at the dip angle from a few degrees to dozens of degrees.

\section{Yangtianping revived caldera}

It is located around Shenxi Village Canyon, Baofu TownZhangcun Town, overall reflecting the whole process of intermittent eruption $\rightarrow$ eruption $\rightarrow$ intermittent $\rightarrow$ eruption $\rightarrow$ eruption and spill $\rightarrow$ subvolcanic rock intrusion. Its basic features are as follow:

\section{(1) Morphological feature}

Caldera spreads like an ellipse, about $120 \mathrm{~km}^{2}$, nearly $10 \mathrm{~km}$ long from east to west and about $12 \mathrm{~km}$ wide from south to north, topographically like a protruding high mountain, planarly distributed like a ring, and on the remote-sensing image there developed clearly irregular circular structures, its margin developed NE-strike, NW-strike, and nearly EW-strike fracture structures, and its surroundings are associated with aeromagnetic anomaly in scale of 1:50,000.

\section{(2) Lithological and lithofacies features}

It is mainly composed of the Member \#1 and \#2 of Huangjian Formation, its outer strata are old and the inner ones are young, and it has the feature of pericline and dipping inward. The early lithofacies combination is the debris-flow accumulative facies interbedded with the volcanic sedimentary facies (rhyolitic dacitic crystal-vitric ignimbrite interbedded with tuffaceous siltstone) $\rightarrow$ the fallout facies (rhyolitic dacitic breccia crystal-vitric tuff) $\rightarrow$ the volcanic sedimentary facies (tuffaceous gravel-bearing siltstone), and the late one is the debris-flow accumulative facies (rhyolitic breccia-bearing crystal-vitric ignimbrite) $\rightarrow$ the extrusive overflow facies (rhyolitic porphyry) $\rightarrow$ the subvolcanic facies (quartz monzonitic porphyry) (Figs. 3.64 and 3.65); both combination's volcanic rocks are in unconformable contact relationship (Fig. 3.66a). The late rhyolitic porphyry in extrusive overflow facies is centered on quartz monzonitic porphyry at Yangtianping, which has relatively complete zonation, its margin features vein-like intrusion, and from inner to outer they are felsitic massive nevadite, felsitic massive rhyolitic porphyry, and vitric massive breccia-bearing rhyolitic porphyry (less speckles); for this suite of strata, its lower has developed horizontal bedding $\left(190^{\circ} \angle 20^{\circ}\right)$ (Fig. 3.66b), its mid has developed horizontal and upright columnar joints and its upper part near the crater developed oblique columnar joints $\left(50^{\circ} \angle 35^{\circ}\right)$.

\section{(3) Structural features}

In the margin of caldera, there are developed radial and circular fractures and the dipstrike for some of them is $250^{\circ} \angle 80^{\circ}, 80^{\circ} \angle 70^{\circ}, 170^{\circ} \angle 30^{\circ}$, and $325^{\circ} \angle 30^{\circ}$, and in the middle there are developed vein groups such as andesite and felsite, where there are plenty of developed andesite agglomerate breccia and veins inside quartz monzonitic porphyry subvolcanic rocks. The northern and western sides of the caldera have the tuffaceous gravel-bearing sandstone in volcanic sedimentary-facie developed early, etc., in the thickness of 47.7-100 m, having the feature of pericline and dipping inward, for instance, the volcanic rock strata are $95^{\circ}-115^{\circ} \angle 13^{\circ}-15^{\circ}$, and $195^{\circ} \angle 27^{\circ}$ in dipstrike, respectively, at Zhangcun in its west and Shenxi Canyon in its north. There are no developed volcanic sedimentary strata in its eastern and southern sides due to late-stage fracture and volcanic eruption. 


\begin{tabular}{|c|c|c|c|c|c|c|c|c|c|c|}
\hline \multicolumn{2}{|c|}{$\begin{array}{c}\text { Active } \\
\text { volcanic zone }\end{array}$} & \multirow{2}{*}{$\begin{array}{c}\begin{array}{c}\text { Eruption } \\
\text { zone }\end{array} \\
\text { Level } \\
\text { III }\end{array}$} & \multirow{2}{*}{\multicolumn{2}{|c|}{$\begin{array}{c}\begin{array}{c}\text { Volcanic-structural } \\
\text { uplift or depression }\end{array} \\
\text { Level } \\
\text { IV }\end{array}$}} & \multirow{2}{*}{\multicolumn{2}{|c|}{ Volcanic apparatus }} & \multirow{2}{*}{$\begin{array}{c}\text { Horizon } \\
\text { lithological for mation }\end{array}$} & \multirow{2}{*}{ Lithof acies combination } & \multirow{2}{*}{$\begin{array}{l}\text { Subvolcanic } \\
\text { rock } \\
\text { (center) }\end{array}$} & \multirow{2}{*}{$\begin{array}{c}\text { Eruption } \\
\text { age }\end{array}$} \\
\hline $\begin{array}{c}\text { Level } \\
\text { I }\end{array}$ & $\begin{array}{c}\text { Level } \\
\text { II }\end{array}$ & & & & & & & & & \\
\hline \multirow{9}{*}{ 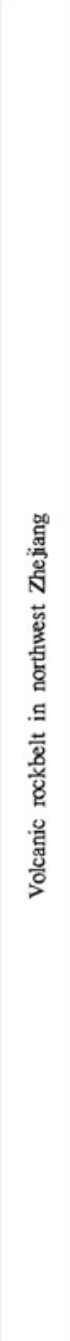 } & \multirow{9}{*}{ 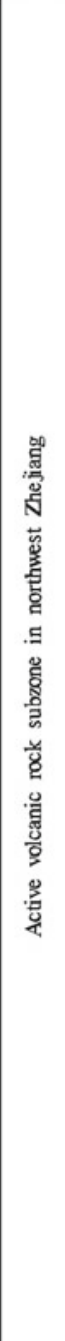 } & \multirow{9}{*}{ 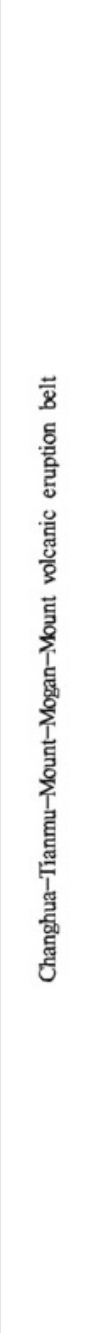 } & \multirow{9}{*}{ 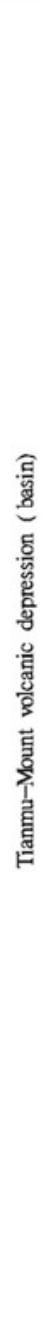 } & \multirow{9}{*}{$\begin{array}{l}\text { Trapezoid; its south } \\
\text { and north sides in } \\
\text { EW-strike or NE- } \\
\text { strike fault or } \\
\text { unconformable } \\
\text { contact, its west } \\
\text { side borders with } \\
\text { NE-strike Xuechuan } \\
\text { - Xiaofeng fault } \\
\text { and its east side is } \\
\text { in fault or intrusive } \\
\text { contact with } \\
\text { Wushanguan } \\
\text { pluton. }\end{array}$} & \multirow{5}{*}{ 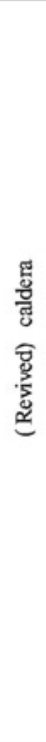 } & Yangtianping & $\begin{array}{l}K_{1} h^{1}, \mathbf{K}_{1} h^{2} \\
\text { Rhyolitic dacitic ignimbrite, } \\
\text { tuff; tuffaceous sandstone; } \\
\text { thyolitic porphyry }\end{array}$ & $\begin{array}{l}\text { Debris-flow facies - fallout } \\
\text { facies - volcanic } \\
\text { sedimentary facies -debris- } \\
\text { flow facies - extrusive } \\
\text { overflow facies -subvolcanic } \\
\text { facies }\end{array}$ & $\begin{array}{l}\text { Quartz } \\
\text { monzonitic } \\
\text { porphyry }\end{array}$ & $\frac{135-125 \mathrm{Ma}}{\text { LA-ICP-MS }}$ \\
\hline & & & & & & Tianhuangping & $\begin{array}{l}\mathrm{K}_{1} h^{3} \\
\text { Rhyolitic dacitic breccia- } \\
\text { bearing ignimbrite; } \\
\text { tuffaceous sandstone; } \\
\text { tuffite }\end{array}$ & $\begin{array}{l}\text { Debris-flow facies - } \\
\text { volcanic sedimentary facies } \\
\text { - subvolcanic facies }\end{array}$ & $\begin{array}{l}\text { Rhyolitic } \\
\text { porphyry }\end{array}$ & $-131 \mathrm{Ma}$ \\
\hline & & & & & & $\begin{array}{c}\text { Changlongshan } \\
1 \\
\text { linjiat ang }\end{array}$ & $\begin{array}{l}\mathrm{K}_{1} h^{2} 、 \mathrm{~K}_{\mathrm{t}} h^{3} \\
\text { Rhyolitic /dacitic breccia- } \\
\text { bearing( strong) ignimbrite; } \\
\text { porphyritic rhyolite and } \\
\text { bubble rhyolite }\end{array}$ & $\begin{array}{l}\text { Debris-flow facies - } \\
\text { volcanic sedimentary facies } \\
\text { - subvolcanic facies }\end{array}$ & $\begin{array}{l}\text { Dacite- } \\
\text { porphyrite }\end{array}$ & $-131 \mathrm{Ma}$ \\
\hline & & & & & & $\begin{array}{l}\text { East Tianmu } \\
\text { ' } \\
\text { Caot anggang }\end{array}$ & $\begin{array}{l}K_{1} h^{2}, K_{1} h^{3} \\
\text { Rhyolitic /dacitic breccia- } \\
\text { bearing( strong) ignimbrite; } \\
\text { porphyritic rhyolite and } \\
\text { bubble rhyolite }\end{array}$ & $\begin{array}{l}\text { Collapse facies ( volcanic } \\
\text { debris--flow facies)- debris- } \\
\text { flow facies - cruptive spill } \\
\text { facies-explosive spill facies- } \\
\text { debris-flow facies }\end{array}$ & & $\frac{132-131 \mathrm{Ma}}{\mathrm{LA}-\mathrm{ICP}-\mathrm{MS}}$ \\
\hline & & & & & & Yaotianfan & $\begin{array}{l}\mathrm{K}_{\mathrm{K}} h^{2} \\
\text { Interbedding of porphyritic } \\
\text { rhyolite and rhyolitic } \\
\text { crystal-vitric ignimbrite }\end{array}$ & $\begin{array}{l}\text { Eruptive spill facies and } \\
\text { fallout facies }\end{array}$ & & $-131 \mathrm{Ma}$ \\
\hline & & & & & \multirow{4}{*}{ 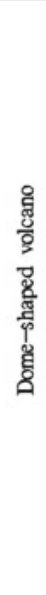 } & $\begin{array}{c}\text { West Tianmu } \\
\text { Mount } \\
1 \\
\text { Longwangshan }\end{array}$ & $\begin{array}{l}\mathrm{K}_{1} h^{2}-\mathrm{K}_{1} h^{4} \\
\text { rhyolitic breccia-bearing } \\
\text { ignimbrite; porphyritic } \\
\text { rhyolite and bubble } \\
\text { rhyolite }\end{array}$ & $\begin{array}{l}\text { Debris-flow facies -eruptive } \\
\text { spill facies }\end{array}$ & & $\frac{132-131 \mathrm{Ma}}{\mathrm{LA}-\mathrm{ICP}-\mathrm{MS}}$ \\
\hline & & & & & & $\begin{array}{c}\text { South Tianmu } \\
\text { Mount } \\
\text { Nanyushan }\end{array}$ & $\begin{array}{l}\mathrm{K}_{1} h^{3} 、 \mathrm{~K}_{\mathrm{l}} h^{4} \\
\text { rhyolitic dacitic ignimbrite; } \\
\text { porphyritic ( bubble) } \\
\text { rhyolite }\end{array}$ & $\begin{array}{l}\text { Debris-flow facies -eruptive } \\
\text { spill facies }\end{array}$ & & $-131 \mathrm{Ma}$ \\
\hline & & & & & & $\begin{array}{l}\text { Shifosi Temple } \\
\text { Wuguishan }\end{array}$ & $\begin{array}{l}\mathrm{K}_{1} h^{3} 、 \mathrm{~K}_{1} h^{4} \\
\text { Rhyolitic dacitic ignimbrite; } \\
\text { porphyritic (bubble) } \\
\text { rhyolite }\end{array}$ & $\begin{array}{l}\text { Debris-flow facies -eruptive } \\
\text { spill facies }\end{array}$ & & $-131 \mathrm{Ma}$ \\
\hline & & & & & & Dashulin & $\begin{array}{l}K_{1} h^{1}, K_{1} h^{4} \\
\text { Tuffaceous glutenite } \\
\text { porphyritic rhyolite and } \\
\text { bubble rhyolite }\end{array}$ & $\begin{array}{l}\text { Volcanic sedimentary facies } \\
\text {-eruptive spill facies }\end{array}$ & & $-131 \mathrm{Ma}$ \\
\hline
\end{tabular}

Fig. 3.63 Division of volcanic apparatus in the survey area

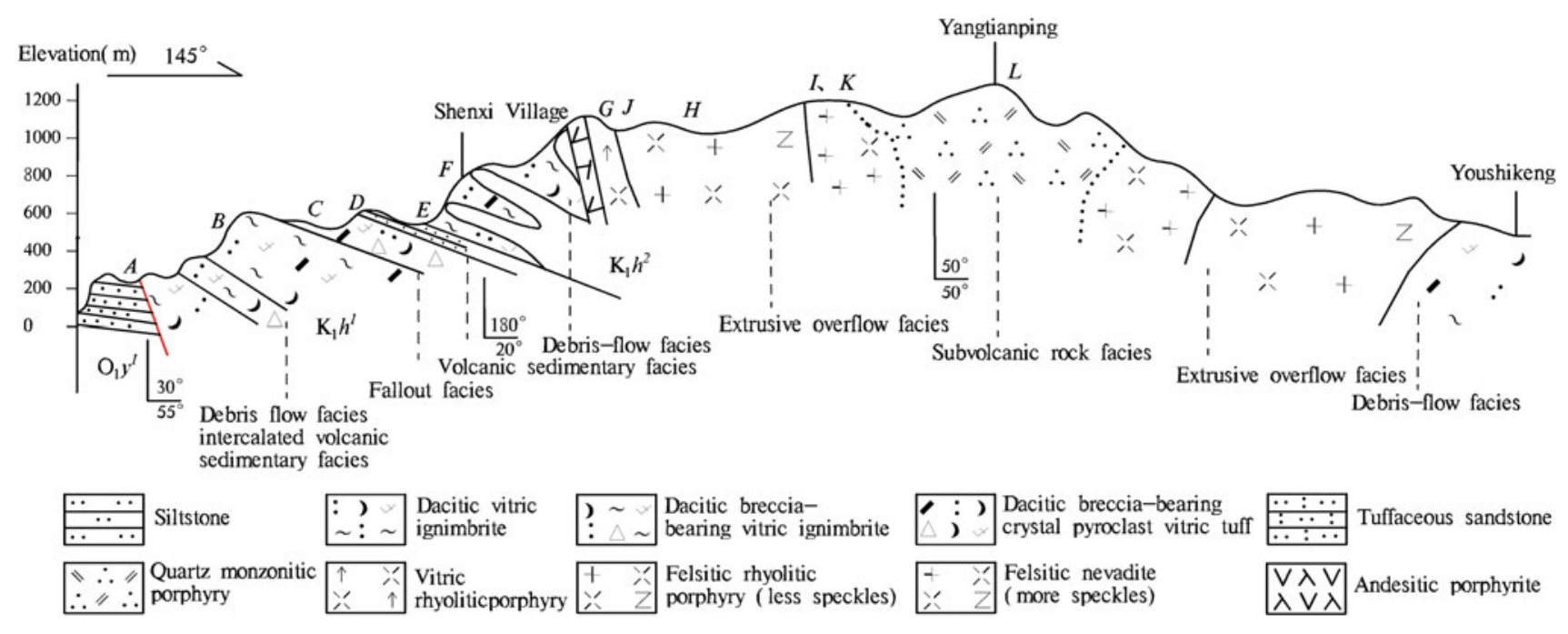

Fig. 3.64 Cross-section profile of Yangtianping revived caldera structure 


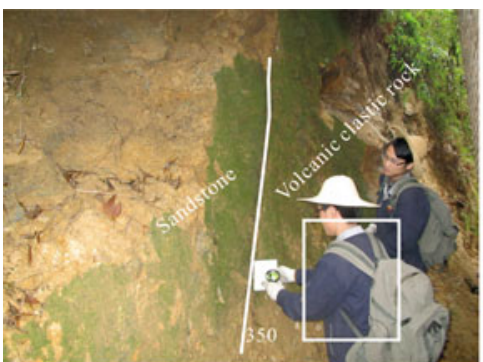

A: $\mathrm{O}, y^{\prime}$ Formation sandstone in fault contact with volcanic rock

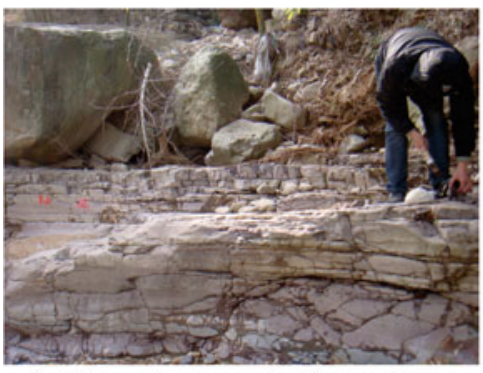

D: Thin-medium-lamellar tuffaceous siltstone

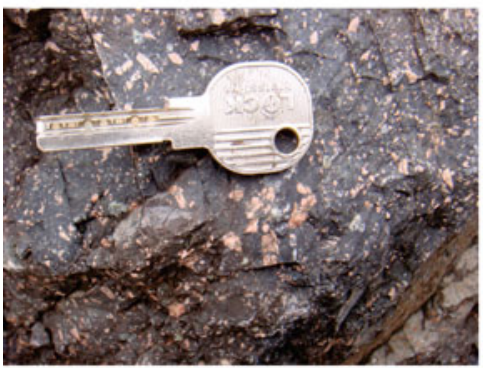

G: Vitric massive rhyolitic porphyry

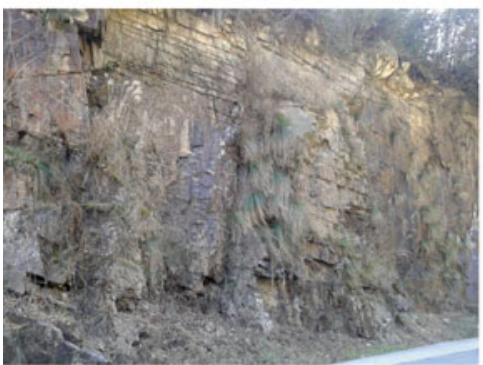

$\mathrm{J}$-Horizontal joints developed in vitric massive nevadite at the margin

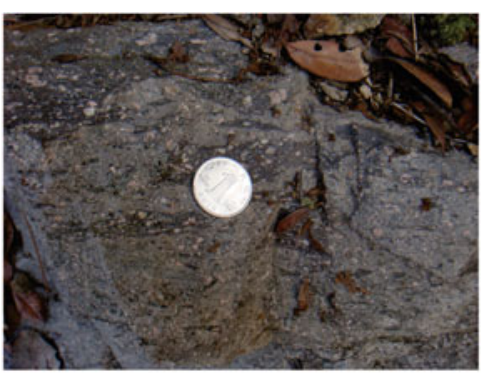

B: Dacitic crystal pyroclast vitric strong ignimbrite

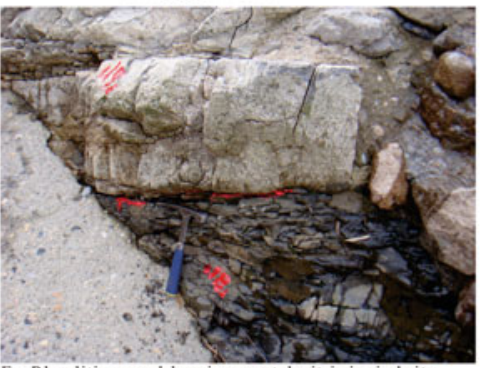

E: Rhyolitic gravel-bearing crystal-vitric ignimbrite conformed above thin-medium-lamellar tuffaceous

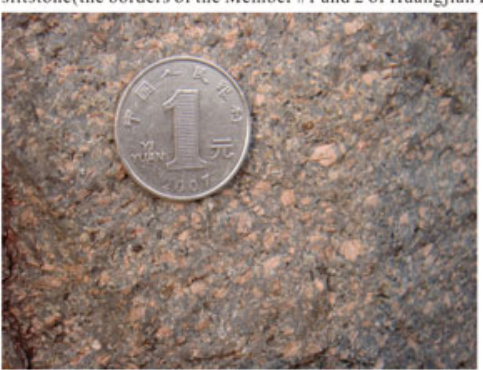

H-Felsitic massive rhyolitic porphyry

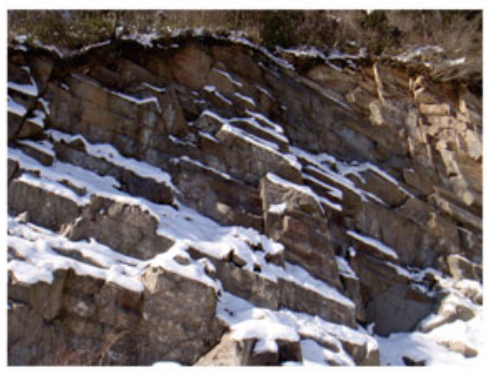

$\mathrm{K}$-Oblique columnar joints developed in felsitic massive nevadite in the mid

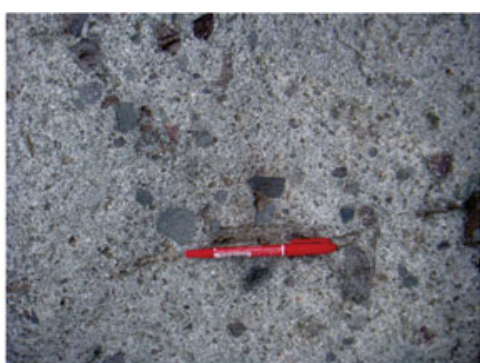

C: Dacitic breccia crystal-vitric tuff

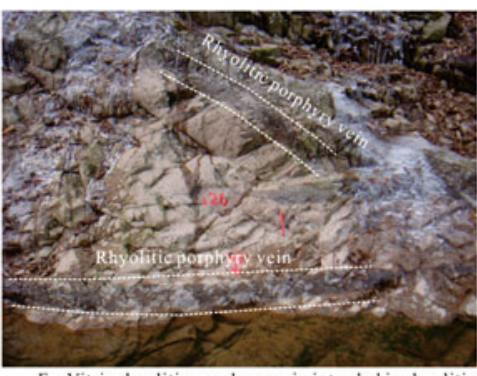

F: Vitric rhyolitic porphyry vein intruded in rhyolitic ravel-bearing crystal-vitric ignimbrite

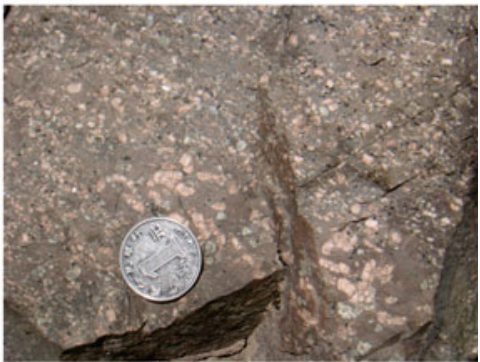

I-Felsitic massive nevadite

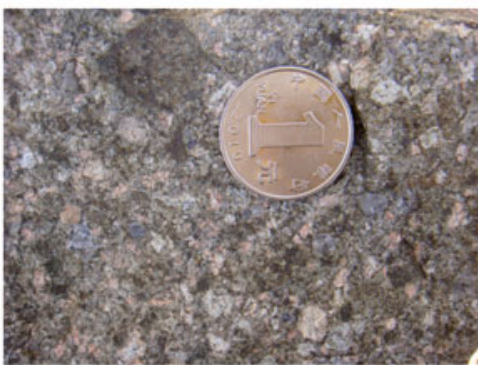

L: Quartz monzonitic porphyry

Fig. 3.65 Images showing field features of Yangtianping revived caldera

(4) Time limit for eruption

Time limit for the caldera eruption was 135.1-125.4 Ma, and it experienced the process of fault depression $\rightarrow$ volcano eruption $\rightarrow$ volcanic collapse and sedimentation $\rightarrow$ reviving and eruption, magmatic extrusion and overflow $\rightarrow$ intrusion of subvolcanic rock in the beginning of Early Cretaceous (Fig. 3.67).

\section{Tianhuangping Caldera}

It is located around Tianhuangping Reservoir (Fig. 3.68), Tianhuangping Town, reflecting the process of eruption $\rightarrow$ intermittence $\rightarrow$ intrusion of subvolcanic rock, and its basic features are as follow: 


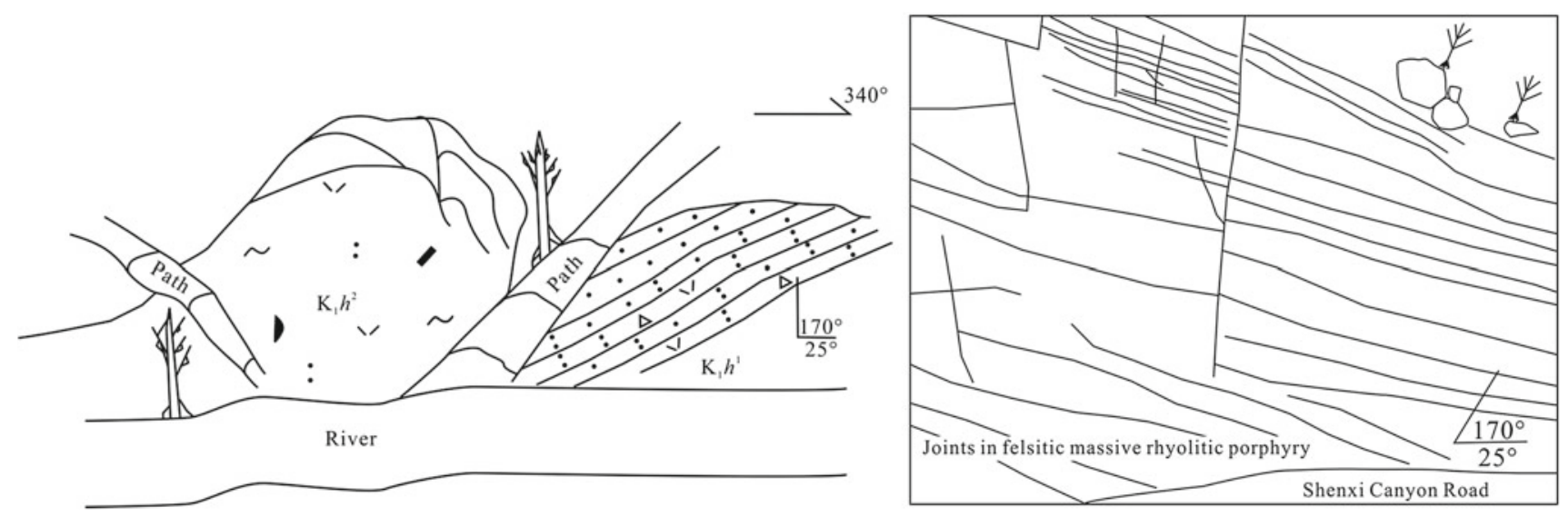

Fig. 3.66 Images showing (rhythmic) unconformable contact relationship between volcanic eruptions in two stages and horizontal joints developed in vitric rhyolitic porphyry in the lower part of late eruption

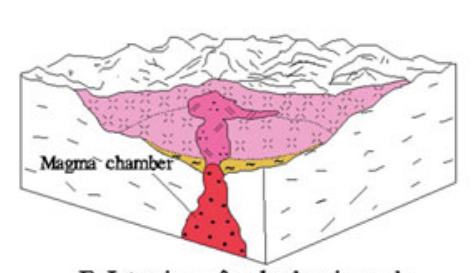

E-Intrusion of subvolcanic rock

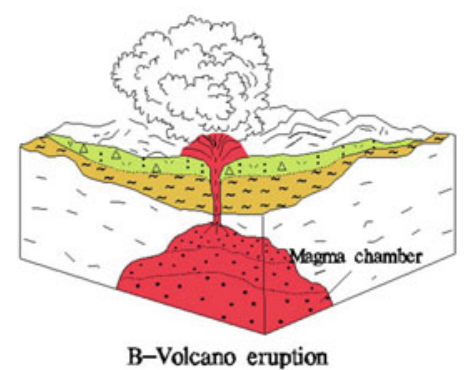

B-Volcano eruption

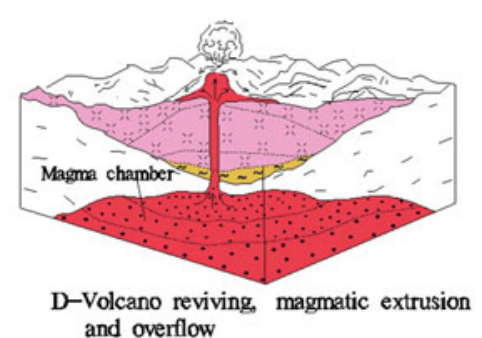
and overflow

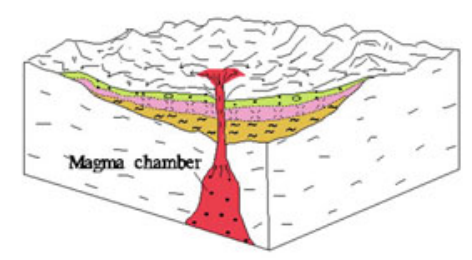

C-Volcano collapse and sedimentation

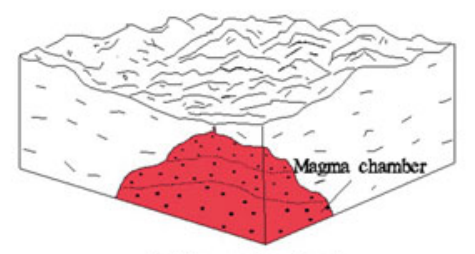

A-Depression basin
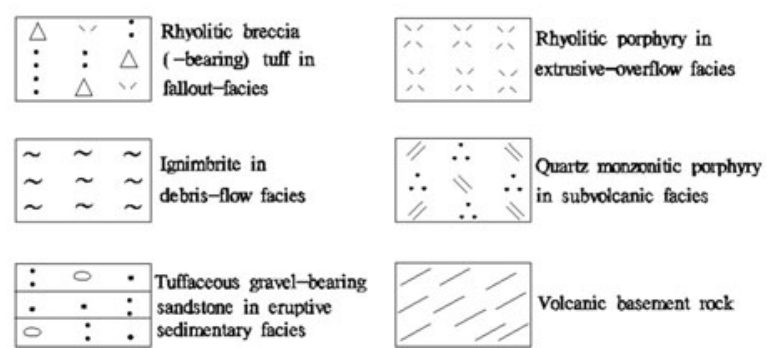

$\therefore \quad \therefore \quad \therefore$ in subvolcanic facies

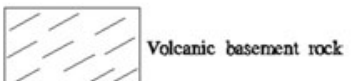

Fig. 3.67 Diagram showing evolution process of the Yangtianping revived caldera

\section{(1) Morphological feature}

Tianhuangping caldera spreads like a long-strip-like ellipse, about $2 \mathrm{~km}^{2}$, nearly $1 \mathrm{~km}$ long from east to west and about $2 \mathrm{~km}$ wide from south to north, topographically like a protruding high mountain (hydropower station), and on the remote-sensing image there developed clearly ellipse-circular structures, and developed aeromagnetic anomaly in scale of 1:50,000.

\section{(2) Lithological and lithofacies features}

It is composed of strata in the Member \#3 of Huangjian Formation, its outer strata are old and the inner ones are young, and it has the feature of pericline and dipping inward, and also planarly distributed like a ring; the lithofacies combination is the debris-flow accumulative facies interbedded with tuffaceous gravel-bearing sandstone (rhyolitic dacitic breccia-bearing crystal-vitric ignimbrite, locally interbedded with tuffaceous-powder gravel-bearing sandstone) $\rightarrow$ the volcanic sedimentary facies (interbeddings of tuffaceous gravel-bearing siltstone, sunken breccia tuff, and tuffite, etc.) $\rightarrow$ the subvolcanic facies(rhyolitic porphyry) (Fig. 3.69).

\section{(3) Structural features}

Perclinal and dipping-inward volcanic sedimentary rocks are developed in the periphery of the caldera, in its south side rhyolitic agglomerate-breccia-bearing crystal pyroclast ignimbrite is of lamination-like structure with the attitude of $330^{\circ} \angle 25^{\circ}$; its west side has developed a large suite of combination of sedimentary breccia tuff, tuffaceous gravel-bearing sandstone, and tuffite, with the attitude of 
$120^{\circ} \angle 20^{\circ}$, and its lower part has developed fold structures and the attitude of both wings of folds are $186^{\circ} \angle 40^{\circ}$ and $20^{\circ} \angle 60^{\circ}$, indicating that volcanic sedimentation was affected by contemporaneous structural movement; its north has developed rhyolitic gravel-bearing crystal-vitric ignimbrite, interbedded with purple-red thin-lamellar tuffite and tuffaceous gravel-sandstone, with the attitude of $210^{\circ} \angle 20^{\circ}$. The rhyolitic porphyry in late subvolcanic facies is in intrusive contact in the south and north sides, with the attitude of the contact surface of $330^{\circ} \angle 70^{\circ}$ and $200^{\circ} \angle 60^{\circ}$.

Within $1-3 \mathrm{~km}$ in the south and east sides of the caldera there are developed subvolcanic rocks such as irregular rhyolitic porphyry and monzonitic porphyry, and veins such as andesite, felsite, and diorite porphyrite.

\section{(4) Time limit for eruption}

It is presumed that the time limit for volcano eruption at the caldera is 132-131 Ma and it generally experienced a process of volcano eruption $\rightarrow$ collapse and sedimentation $\rightarrow$ intrusion of volcanic rock.

\section{Changlongshan-Linjiatang Caldera}

It is located in Linjiatang village, Gaohong town, Lin'an District, with the following features:

\section{(1) Morphological feature}

Changlongshan-Linjiatang caldera spreads like a long strip in NW-strike, about $10 \mathrm{~km}^{2}$, some $5 \mathrm{~km}$ long from northwest to southeast and $2 \mathrm{~km}$ wide from northeast to southwest, topographically in the shape of protruding high mountain. In the remote-sensing image, NW-strike circular structure developed, with 1:50,000 aeromagnetic anomaly, which is cut off by a later NE-strike fracture.

(2) Lithological and lithofacies features

Its west side is composed of rhyolitic dacitic breccia-bearing crystal-vitric ignimbrite of the Member \#3 of Huangjian Formation, and its east side is distributed with the Member \#2 of Huangjian Formation rhyolitic tuff lava and daciteporphyrite in center's subvolcanic rock lithology (Figs. 3.70 and 3.71).

\section{(3) Structural features}

In the northwest and southwest sides of the caldera, a handful of tuffaceous glutenite and tuffaceous gravel-bearing siltstone, which have features of being slightly oblique and dipping inward outcrops about $1.5 \mathrm{~m}$ thick, the tuffaceous gravel-bearing sandstone in the lower part is $5-20 \mathrm{~cm}$ per

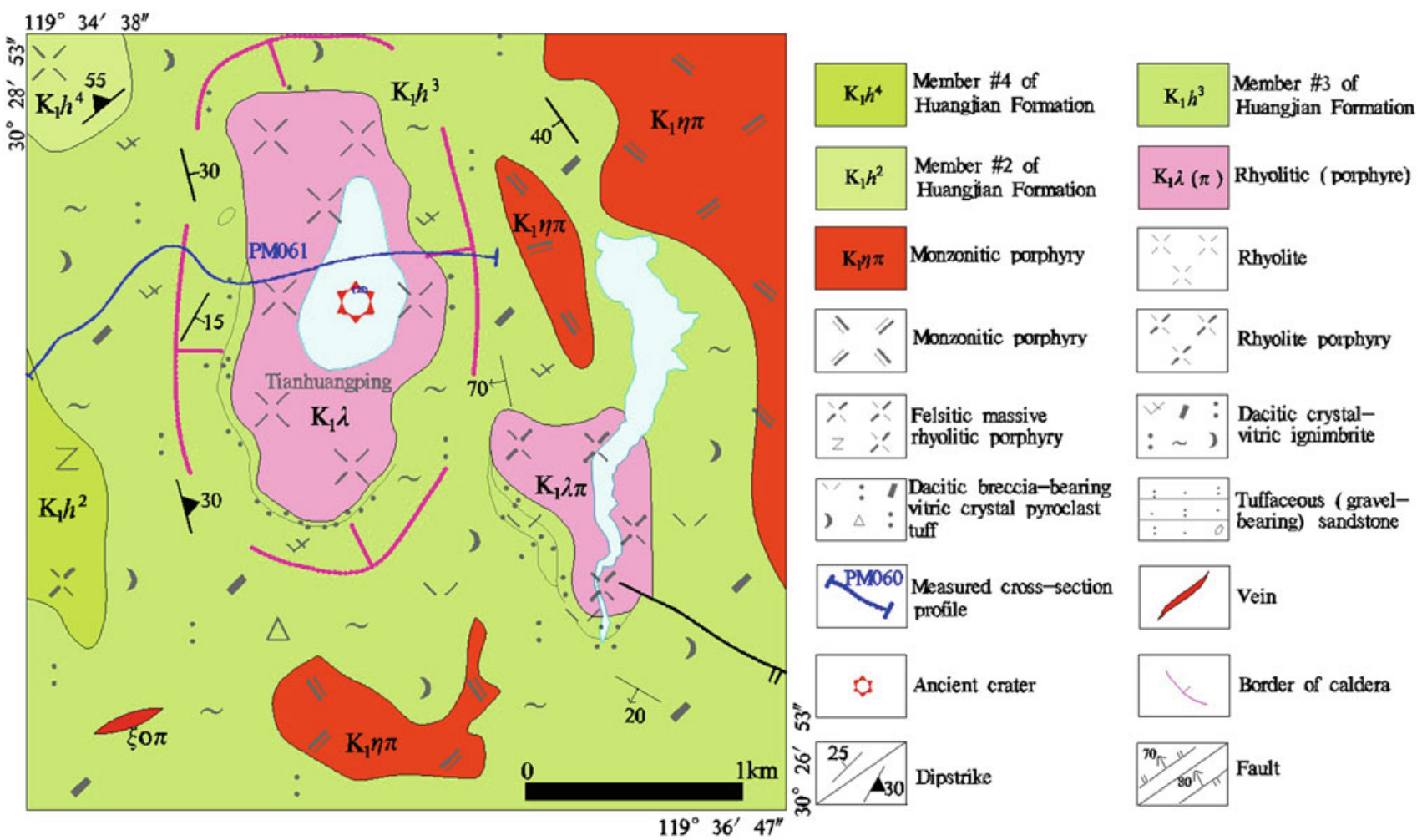

Fig. 3.68 Structural geological map of the Tianhuangping caldera 


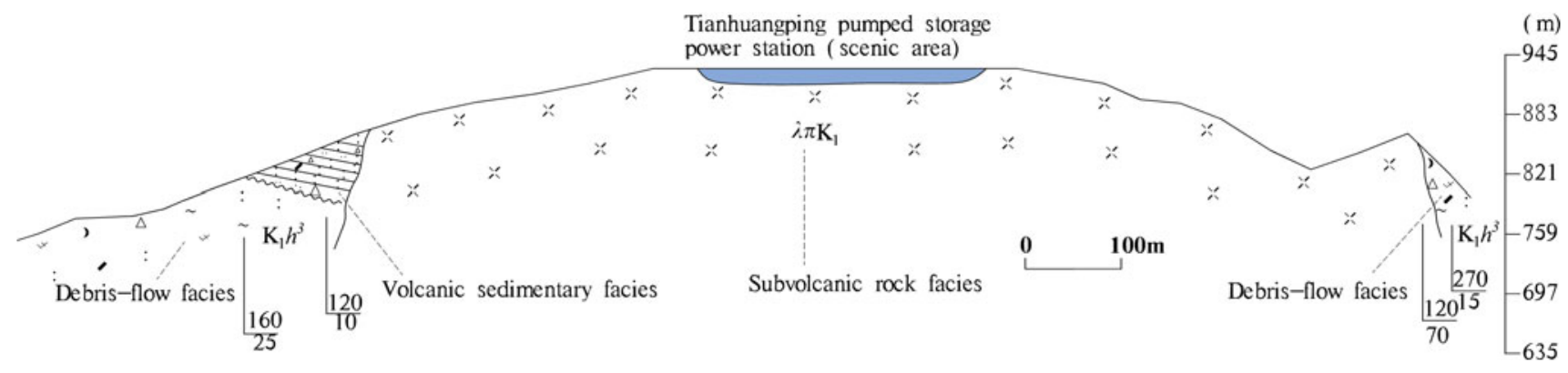

Fig. 3.69 Tianhuangping caldera cross-section profile

layer and the glutenite in the upper is strongly weathered, due to different components, gravel contour is clearly visible, gravel is $30-50 \%$ in content, about $1-8 \mathrm{~cm}$ in size generally, $10-20 \mathrm{~cm}$ for big ones, in the subangular shape, and a few gravel is $40-50 \mathrm{~cm}$ in size and in the shape of ellipse; their attitude is $140^{\circ} \angle 25^{\circ}, 125^{\circ} \angle 15^{\circ}$, and $90^{\circ} \angle 20^{\circ}$, respectively. In the late period, the caldera is cut off into two parts by intrusion of the Wushanguan composite pluton with fine-grained syenogranite apophysis, and silicification alteration developed at the margin of intrusive contact.

(4) Time limit for eruption

It is presumed that the time limit for volcano eruption at the caldera is about $131 \mathrm{Ma}$.

\section{East Tianmu Mount-Caotanggang Revived Caldera}

It is located in East Tianmu Mount, Lin'an District, in the south of the survey area, a well-preserved volcanic apparatus, in high elevation topographically, the peak of East Tianmu Mount is $1479 \mathrm{~m}$ above sea level and its main features are as follow:

\section{(1) Morphological feature}

Planarly it is ellipse, nearly $6 \mathrm{~km}$ long from east to west and 4-5 $\mathrm{km}$ wide from south to north, high and steep in the lower part and gentle in the peak; its south side is in angular unconformable contact with calcareous mudstone and marlstone in Cambrian-Ordovician Xiyangshan Formation, with the strata attitude of $50^{\circ} \angle 40^{\circ}$, and in NW-strike fault contact in the East Tianmu Mount Scenic Area (Fig. 3.72). In the remote-sensing image, there is clearly developed ellipse-circular structure associated with 1:50,000 aeromagnetic anomaly in the mid and margin, which is cut off by a NE-strike fracture later.
(2) Lithological and lithofacies features

Strong in scale and intensity in the early, and it mainly reflects that erupted and collapsed acid magma washed by water flow and then sedimented and afterward it experiences eruptive and explosive spill so that it formed a set of lithology which was rhyolitic agglomerate breccia and crystal-vitric tuff in the lower, and porphyritic (bubble) rhyolite and rhyolitic tuff lava in the upper.

\section{(3) Structural features}

The early stage rock is largely lamellar, periclinal, and dipping inward, with steep dip angle, and the attitude of rhyolitic agglomerate breccia in the bottom is $50^{\circ} \angle 35^{\circ}$ and the attitude of rhyolite in the mid varies greatly, which is $110^{\circ} \angle 75^{\circ}, 220^{\circ} \angle 30^{\circ}$, and $45^{\circ} \angle 40^{\circ}$; there are two lateral craters in the west of Caotanggang. The late is mainly eruption of neutral-acid magma in small scale, only distributed in East Tianmu Mount, and its lithology is rhyolitic dacitic (breccia-bearing) crystal-vitric ignimbrite, especially inner rock which has the feature of strong clinkering, and the false-rhyolitic attitude is $55^{\circ} \angle 15^{\circ}, 30^{\circ} \angle 25^{\circ}$, and $60^{\circ} \angle 70^{\circ}$ (Fig. 3.73).

\section{(4) Time limit for eruption}

On the basis of the zircon LA-ICP-MS U-Pb age of the early rhyolitic crystal-vitric tuff in the lower part (which is $132.1 \pm 1.1 \mathrm{Ma}$ ), it is presumed that the time limit for the caldera is about $132 \mathrm{Ma}$; it generally experiences a process of eruption and sedimentation $\rightarrow$ magma overflow and explosive spill $\rightarrow$ reviving and eruption.

\subsubsection{Dome-Shaped Volcano}

Dome-shaped volcanic apparatus is a dome-shaped body formed by intrusive bodies and spilled lava. When 


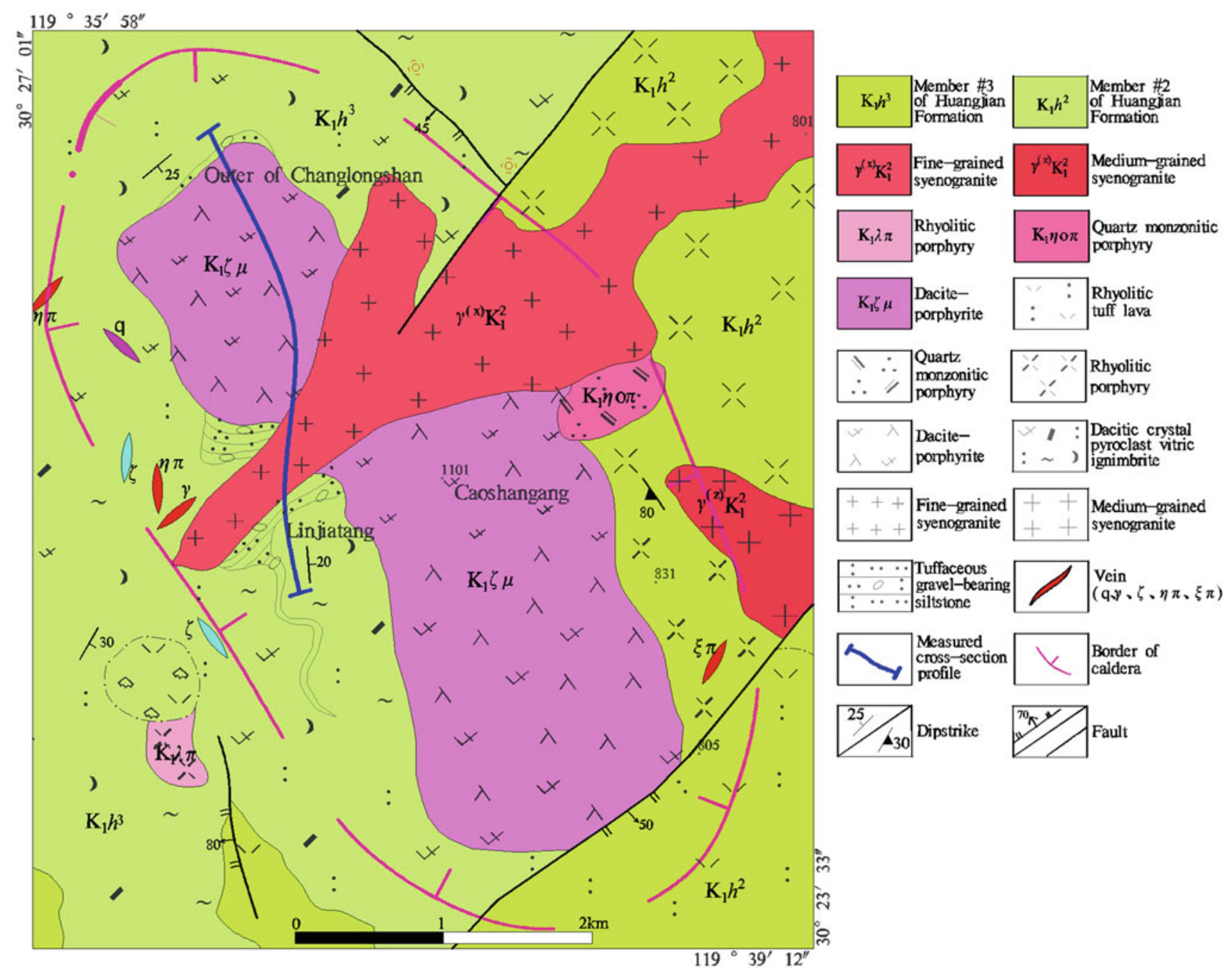

Fig. 3.70 Structural geological map of the Changlongshan-Linjiatang caldera

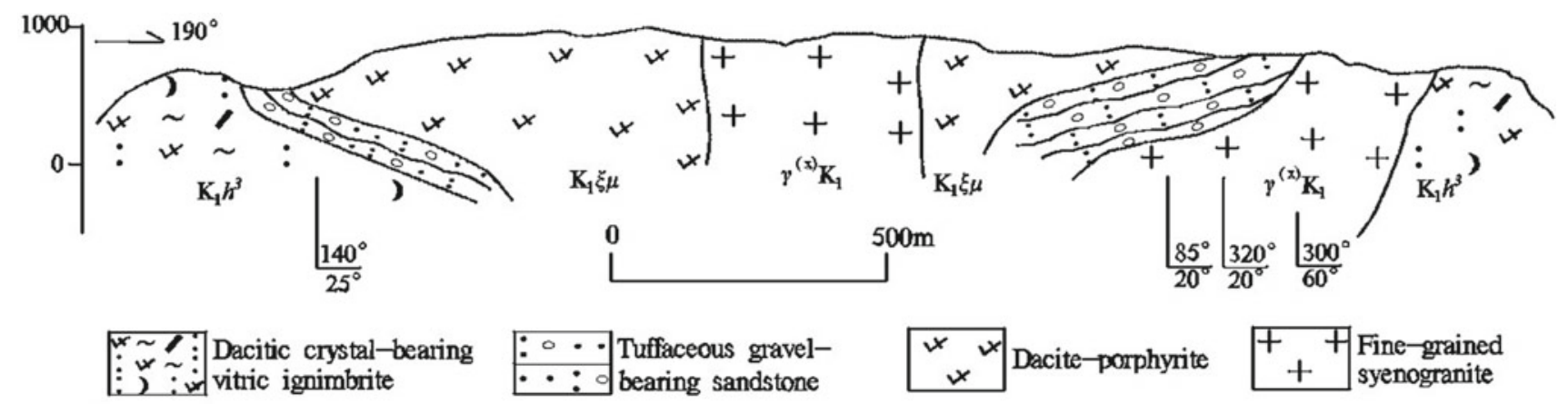

Fig. 3.71 Cross-section profile map of the Changlongshan-Linjiatang caldera

high-viscosity lava materials extruded out of the volcanic vent, they accumulated around or above the exit and do not overflow to form intrusive bodies, but at the same time lava that overflew slightly earlier is hunched up due to increased lava pressure so that it becomes the shape of a dome which is steep at the margin, gentle in the center and has cupola and lava dome in the peak. Main rocks constituting a dome-shaped volcanic apparatus are acid and neutral-acid rocks such as rhyolite and dacite, as well as trachyte and andesite. 


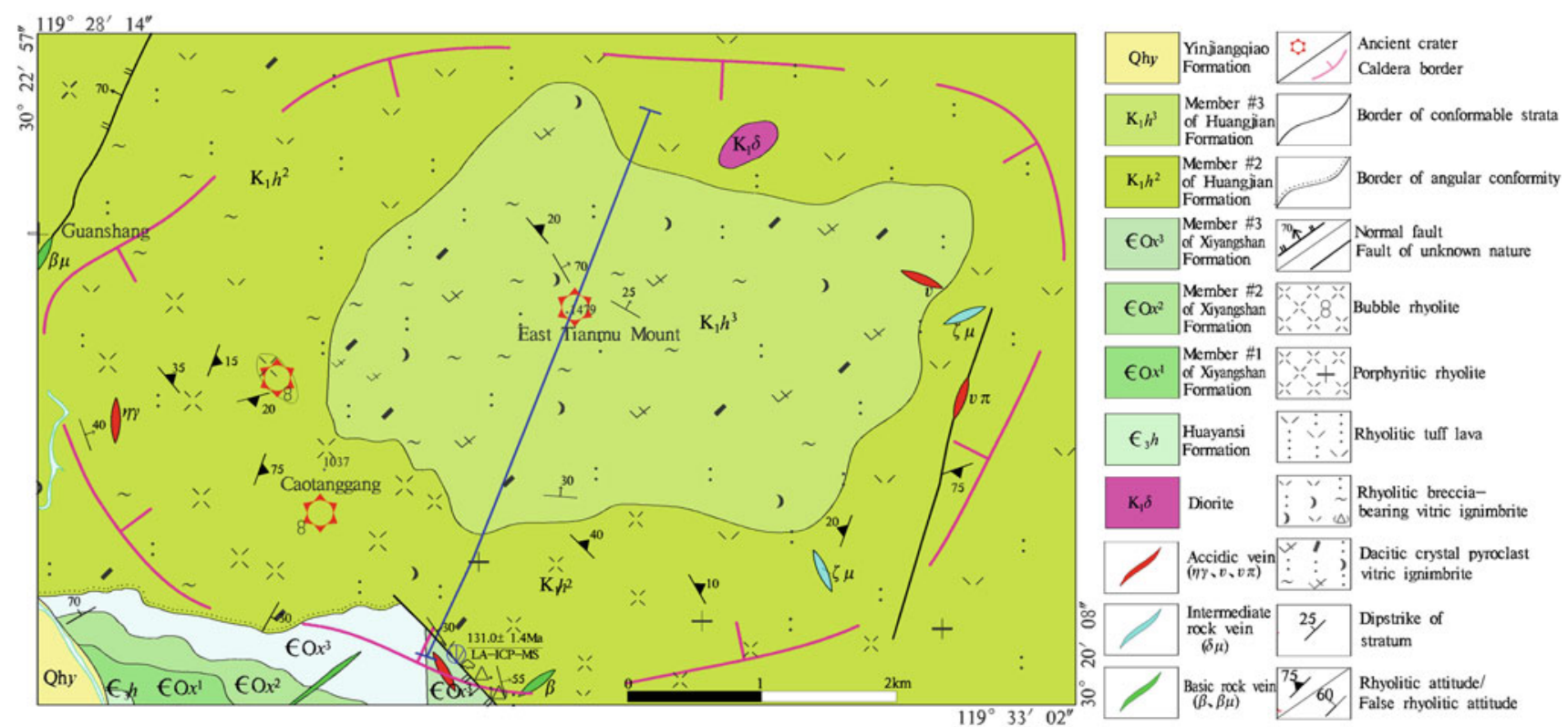

Fig. 3.72 Structural geological map of East Tianmu Mount-Caotanggang Revived Caldera

\section{West Tiannu Mount-Longwang Mount dome-shaped volcano}

The dome-shaped volcano situated at West Tianmu MountLongwang Mount national natural reserve in the south of the survey area, topographically with high elevation, and the highest elevation is $1505 \mathrm{~m}$ and $1587 \mathrm{~m}$, respectively, at West Tianmu Mount and Longwang Mount. There mainly reflects eruption and spill of acid magma with the basic features as below:

\section{(1) Morphological feature}

It is in the NW-strike, nearly $8 \mathrm{~km}$ long and $2-5 \mathrm{~km}$ wide, steep at its margin, like a cliff at local places and rather flat at the upper. In the remote-sensing image there is clearly developed ellipse-circular structures, and NE-strike and $\mathrm{NW}$-strike fracture structures at the margin.

\section{(2) Lithological and lithofacies features}

Lithology and lithofacies is mainly composed of the eruptive spill facies porphyritic rhyolite and bubble rhyolite of the Member \#4 of Huangjian Formation (Fig. 3.74), porphyritic rhyolite in its lower part or margin has developed rhyolitic structure, phenocryst is $10-25 \%$ in content and has developed bubble structure with bubble in the size of $0.5-2 \mathrm{~cm}$ and content of $5-15 \%$; its center is mainly rhyolite with more speckles, where phenocryst content is $25-70 \%$.

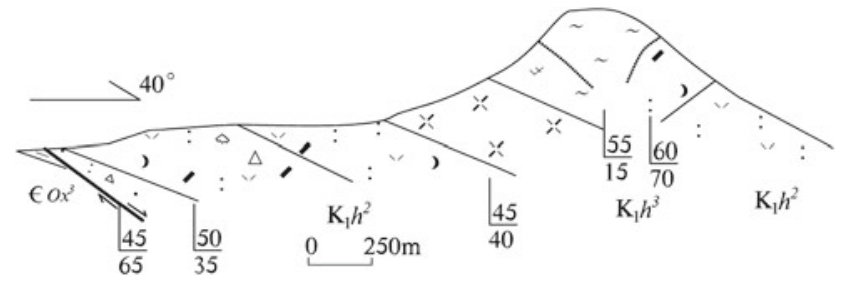

Fig. 3.73 Cross-section profile of East Tianmu Mount-Caotanggang Revived Caldera

\section{(3) Structural features}

Porphyritic rhyolitic in its western is in eruptive unconformable contact with the attitude of $110^{\circ} \angle 50^{\circ}$, its east side is in NE-strike fault contact with Cambrian strata, with the fracture attitude of $300^{\circ} \angle 80^{\circ}$ (Fig. 3.75); rocks at the margin have developed rhyolitic structure with complex attitude, its attitude dips toward NE or East $\left(80^{\circ}-120^{\circ} \angle 20^{\circ}-40^{\circ}\right)$ in general, and toward south locally $\left(180^{\circ}-210^{\circ} \angle 15^{\circ}-20^{\circ}\right)$, there is no rhyolitic structure developed inner rocks but have developed round upright columnar joints structure, in the diameter of $20-100 \mathrm{~cm}$ per column; the features of rhyolitic attitude indicates it flows eastward in general.

(4) Time limit for eruption

Zircon LA-ICP-MS U-Pb age for porphyritic rhyolite is $131 \pm 1$ Ma. 


\section{South Tianmu Mount Dome-shaped Volcano}

South Tianmu Mount dome-shaped volcano, together with Nanyushan and Shifo Temple dome-shaped volcanos, are distributed like bead streams in the EW strike, in the north of the survey area, also having relatively high elevation topographically, with the main features as below:

\section{(1) Form and shape feature}

Planarly in the shape of ellipse-round, $2-4 \mathrm{~km}$ long from east to west and $1-3 \mathrm{~km}$ wide from south to north, similarly it is steep in the lower part and flat at the mount peak. In the remote-sensing image, there is clearly developed ellipsecircular structure, with 1:50,000 aeromagnetic anomaly developed in the margin.

\section{(2) Lithological and lithofacies features}

Lithology in the lower part is mainly neutral-acid rhyolitic dacitic (breccia-bearing)crystal-vitric ignimbrite in the accumulation of debris flow early stage erupted, and locally has developed rock strata or interbedding of tuffaceous gravel-bearing sandstone and agglomerate breccia, about 20-100 cm per layer, for instance, the attitude of volcanic sedimentary interbedding is $140^{\circ} \angle 45^{\circ}$ and $290^{\circ} \angle 25^{\circ}$, respectively, at the north of South Tianmu Mount and at the east of Nanyushan; lithology in the upper part is mainly the late-stage eruptive spill facies' porphyritic rhyolite, and the attitude of rhyolitic structures is complex, generally having the feature of dipping southward or southeastward $\left(120^{\circ}\right.$ $213^{\circ} \angle 30^{\circ}-80^{\circ}$ ) (Figs. 3.76 and 3.77 ), locally have developed bubble rhyolite, in the bubble size of $0.3-5 \mathrm{~cm}$, concentratively distributed like laminations, bubble rare at local places. Around the dome-shaped volcano, volcanic rocks are composed of quartz monzonitic porphyry and rhyolitic porphyry, as well as veins such as sillite and diorite.

\section{(3) Time limit for eruption}

The zircon LA-ICP-MS U-Pb age of porphyritic rhyolite in West Tianmu Mount Dome-shaped volcano is $131 \pm 1 \mathrm{Ma}$, as the eruption time limit.

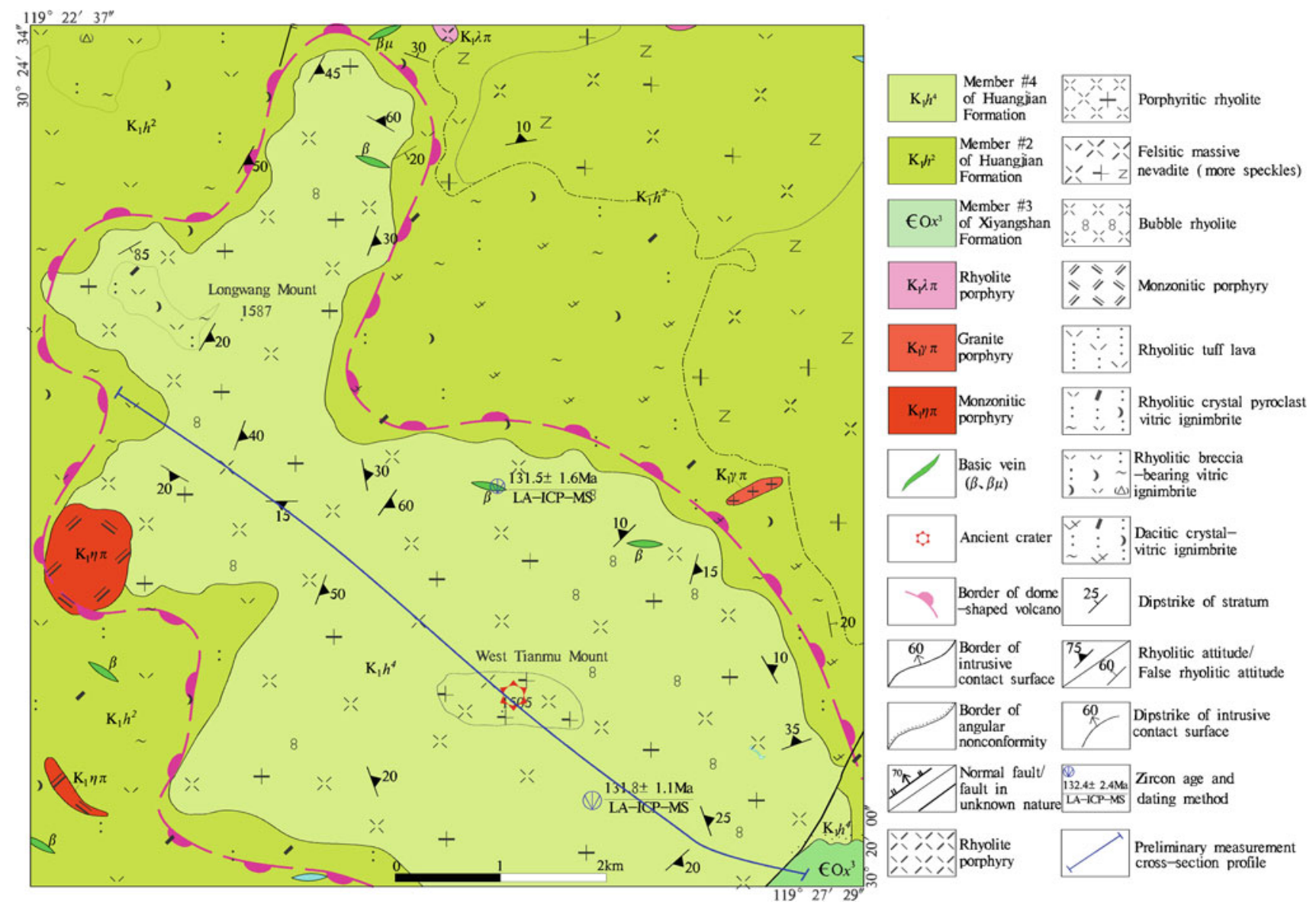

Fig. 3.74 Structural geological map of West Tianmu Mount-Longwang Mount dome-shaped volcano 


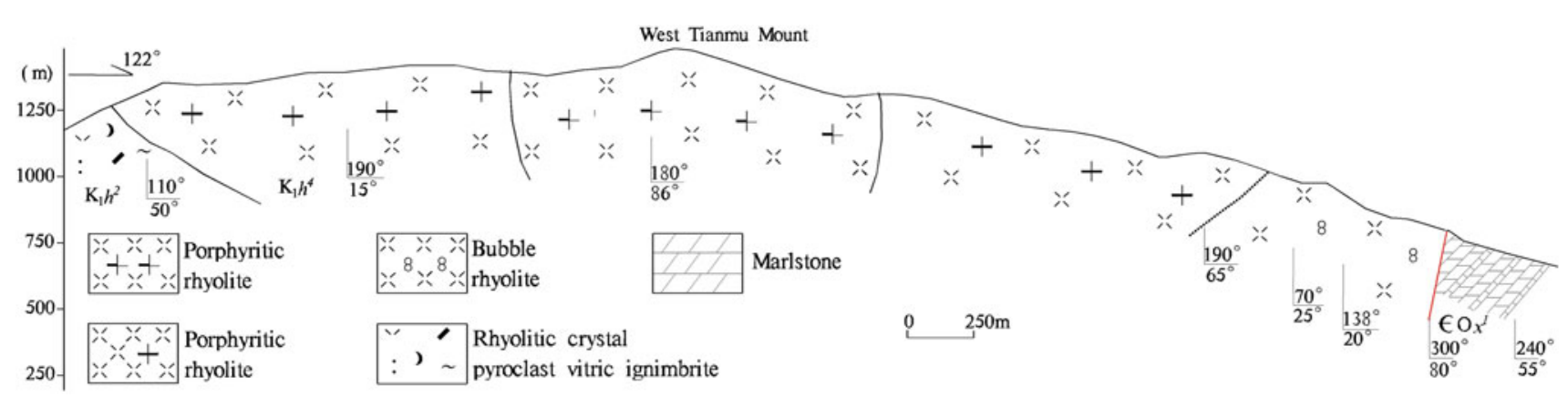

Fig. 3.75 Structural cross-section profile of West Tianmu Mount-Longwang Mount dome-shaped volcano

\section{Dashulin Dome-shaped Volcano}

Dashulin dome-shaped volcano is distributed Lin'am Yuanlinwukou at the southwest corner of the volcanic rock area of the survey area, with the following main features:

\section{(1) Morphological feature}

Planarly in the shape of long-strip ellipse, about $2 \mathrm{~km}$ long from south to north and $1.5 \mathrm{~km}$ wide from east to west, similarly it is steep in the lower part and flat at the mountain peak, extending south beyond the survey area (Fig. 3.78).

\section{(2) Lithological and lithofacies structural features}

Western of the volcano is in angular unconformable contact with Ordovician Changwu Formation siltstone strata, and locally in NE-strike fault contact. Around its bottom, there are developed tuffaceous glutenite and gravel-bearing sandstone, with gravel content of $20-25 \%$ and gravel size of $2-500 \mathrm{~mm}$, varying greatly, which is generally rounded, subangular, subrounded, long-flat, and irregular, mainly sandstone (20\%), quartz (5\%), and volcanic rock (75\%), 10-15 cm thick per layer, and a handful of gravel are arranged in oblique rows; of this suite of rock strata, the west and north sides are the most developed, with the attitude of $130^{\circ} \angle 40^{\circ}$ in the west and $230^{\circ} \angle 30^{\circ}$ in the north. The mid-part of local places in the north has a handful of sandwich of dacitic breccia-bearing crystal pyroclast vitric ignimbrite, and the attitude of rhyolitic-like structure is $230^{\circ} \angle 30^{\circ}$. It the upper part, it is a suite of porphyritic rhyolite, the attitude of rhyolitic structure is $130^{\circ} \angle 20^{\circ}, 230^{\circ} \angle 48^{\circ}, 165^{\circ} \angle 25^{\circ}$, and $220^{\circ} \angle 20^{\circ}$, tilting southward overall (Fig. 3.79). Around the dome-shaped volcano, there are developed subvolcanic rocks and veins such as
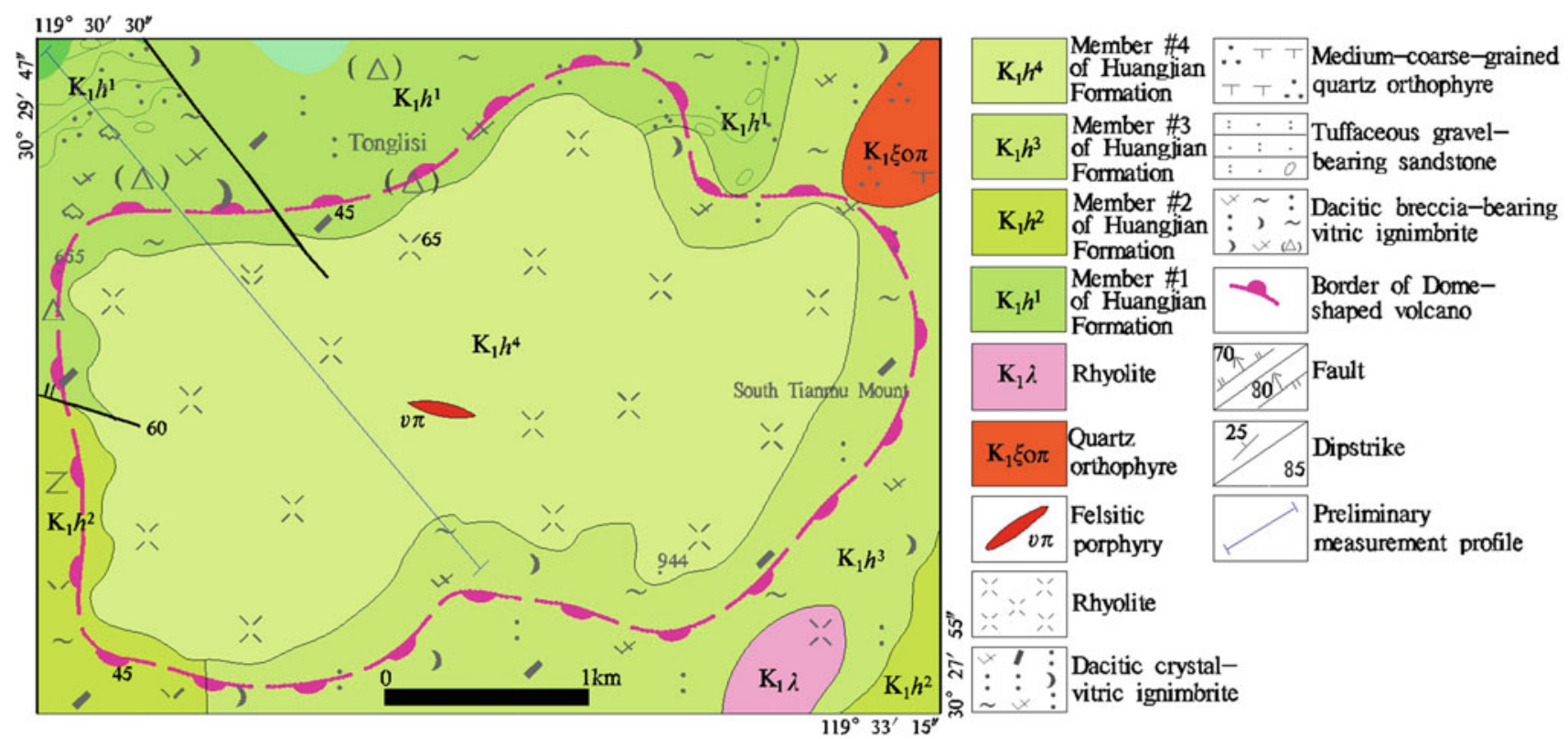

Fig. 3.76 Structural geological map of South Tianmu Mount-Longwang Mount dome-shaped volcano 


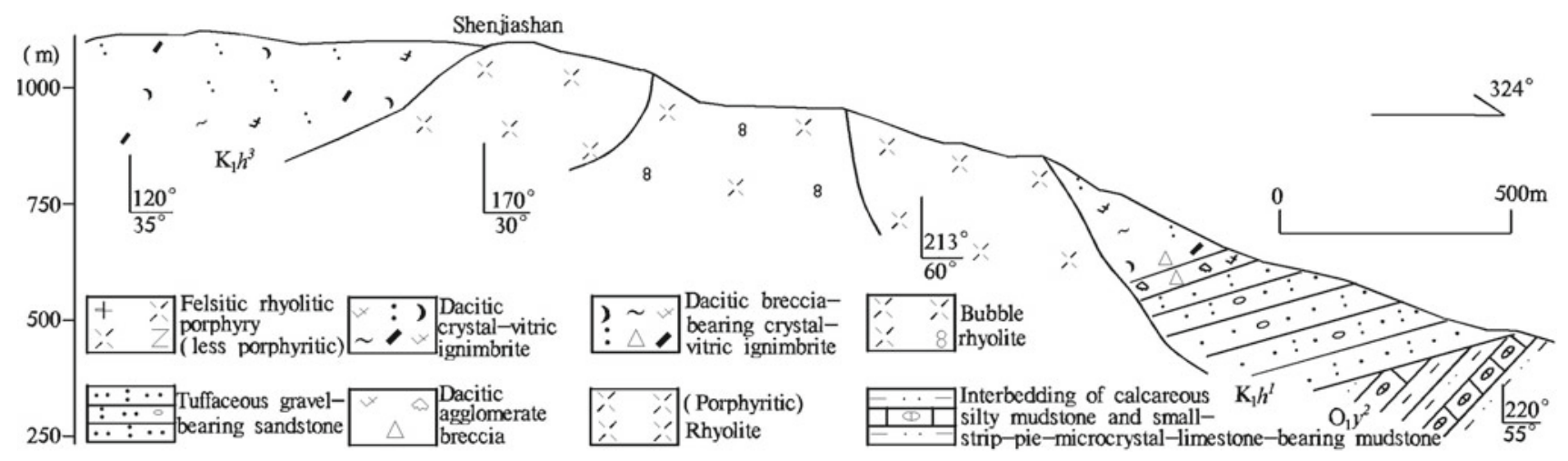

Fig. 3.77 Structural cross-section profile of South Tianmu dome-shaped volcano

granite porphyry, monzonitic porphyry, orthophyre, and dacite-porphyrite.

(3) Time limit for eruption

It is presumed that the time limit for its volcanic action is similar to that of West Tianmu Mount dome-shaped volcano $(131 \pm 1 \mathrm{Ma})$.

\subsubsection{Regularity on Volcano Structural and Product Migration}

In the survey area, volcanic apparatuses typically have the feature of bead-stream combinations, for instance: in the west side, West Tianmu Mount -Longwang Mount, South Tianmu Mount, and Nayushan dome-shaped volcanos, and Yangtianping revived caldera have clearly NE-strike arrangement feature; in the east side, South Tianmu Mount dome-shaped volcano, and Tianhuangping, LinjiatangChanglong Mount and Yaotianfan calderas have the spatial combinations of NW-strike bead-stream-like arrangement; in the north side, South Tianmu Mount, Nanyushan and Shifo Temple dome-shaped volcanos have the feature of nearly EW-strike arrangement; in the south side, West Tianmu Mount-Longwan Mount and East Tianmu MountCaotanggang dome-shaped volcanos and Yaotianfan caldera also have the feature of nearly EW-strike arrangement, all
Fig. 3.78 Structural plane of Dashulin dome-shaped volcano

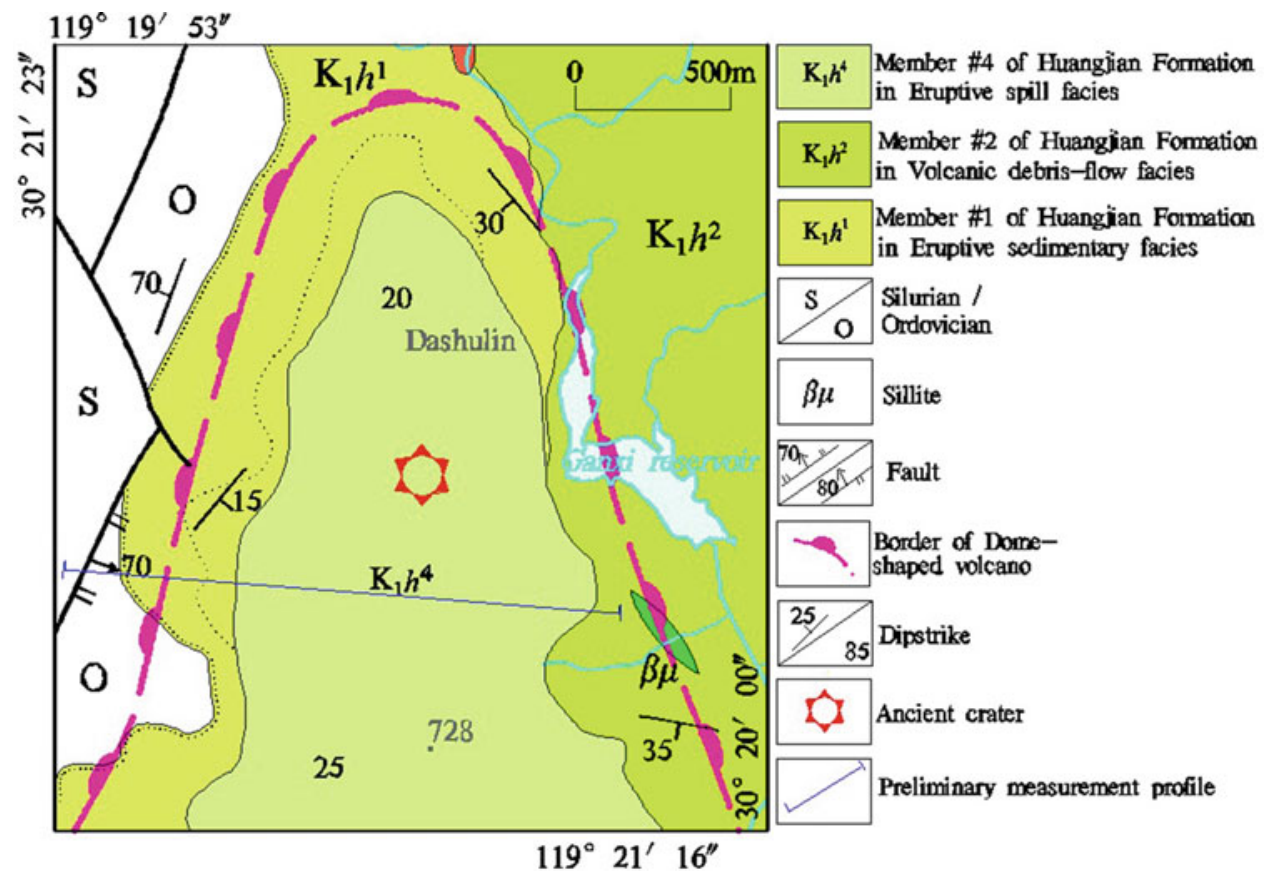




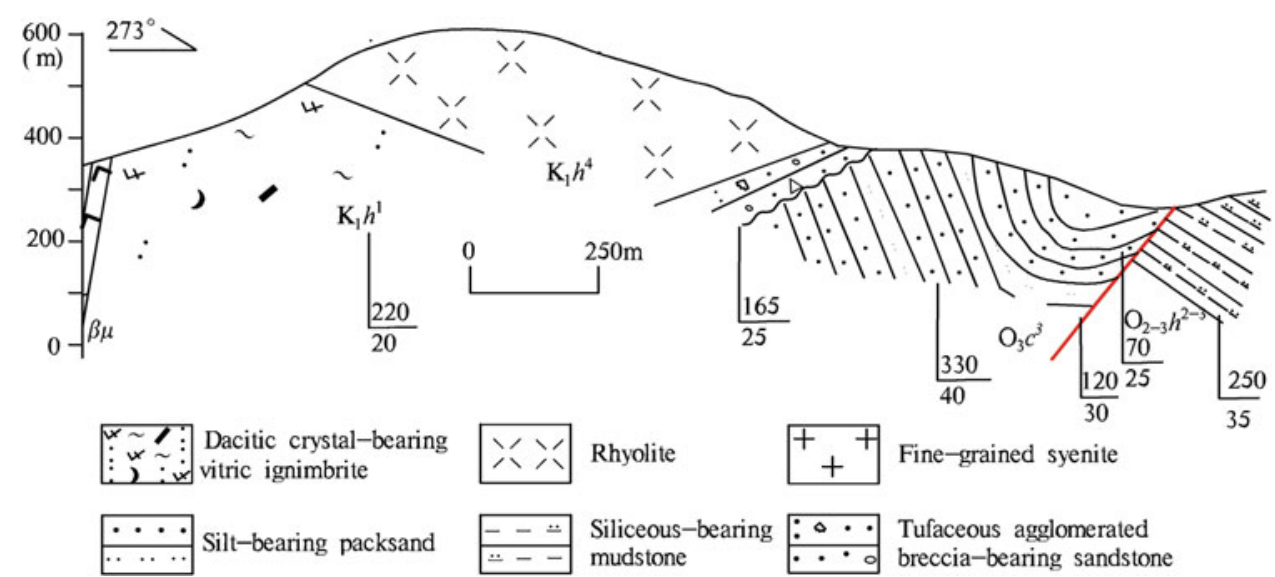

Fig. 3.79 Structural profile of Dashulin dome-shaped volcano

these indicate the controlling effect of the deep basement structure on volcanic apparatuses, constituting a normal-trapezoid volcanic basin. In general, in the survey area, volcanic structures feature migration from the central to east, north, and south, and the volcanism shows an evolution feature that is dominated by eruption in the early stage, extrusive overflow, eruptive spill, and explosive spill in the mid-stage, and eruption in the late stage.

\subsubsection{Geochemical Characteristics and Tectonic Setting of the Volcanic Rocks}

\subsubsection{Geochemical Features}

\section{Volcanic rocks}

In the survey area, volcanic rocks in the Huangjian Formation is high in $\mathrm{SiO}_{2}$ content (66.68-76.90\%), enrichment in alkali (Alk $=\mathrm{K}_{2} \mathrm{O}+\mathrm{Na}_{2} \mathrm{O}$, 7.15-9.93\%) (Fig. 3.80), high in $\mathrm{K}_{2} \mathrm{O} / \mathrm{Na}_{2} \mathrm{O}$ ratio $(1.37-2.80 \%)$; low in $\mathrm{MgO}(0.24$ $1.14 \%), \mathrm{P}_{2} \mathrm{O}_{5}(0.03-0.13 \%)$, and $\mathrm{TiO}_{2}(0.14-0.45 \%)$; the DI index is high (81.04-93.21), similar to that of intrusive rocks. From the Member \#1 to \#4 of Huangjian Formation, the contents of $\mathrm{SiO}_{2}, \mathrm{~K}_{2} \mathrm{O}$, and $\mathrm{TiO}_{2}$, and the $\mathrm{K}_{2} \mathrm{O} / \mathrm{Na}_{2} \mathrm{O}$ ratio show a trend of gradual increase, and the contents of $\mathrm{Al}_{2} \mathrm{O}_{3}, \mathrm{TFeO}, \mathrm{MgO}, \mathrm{CaO}$, and $\mathrm{P}_{2} \mathrm{O}_{5}$ show the trend of increase and then decrease. In general, $\mathrm{Al}_{2} \mathrm{O}_{3}, \mathrm{CaO}, \mathrm{MgO}$, $\mathrm{FeO}, \mathrm{TiO}_{2}, \mathrm{P}_{2} \mathrm{O}_{5}$, and $\mathrm{Fe}_{2} \mathrm{O}_{3}$ have a negative correlation with $\mathrm{SiO}_{2}$, while $\mathrm{K}_{2} \mathrm{O}$ has no clear correlation with $\mathrm{SiO}_{2}$. All these features suggest that as differentiation evolution becoming more sufficient, lithologies evolve toward acidity and their alkalinity does not change greatly. A/CNK is $0.91-$ 1.18 , featuring evolution from metaluminous to weakly peraluminous (Fig. 3.81); Rittmann Index $(\sigma)$ is $1.51-3.72$ having the features of shoshonite series. $\mathrm{TFeO} / \mathrm{MgO}$ ratio is 2.85-9.70, average value (6.17) is close to the I-type granite (2.27) (Whalen et al. 1987), but very different from A-type granite (13.4) (Turner et al. 1992).

Volcanic rocks are medium or high in $\sum$ REE content $\left(151.99 \times 10^{-6}-296.83 \times 10^{-6}\right), \quad$ and the chondrite-normalized REE patterns show the feature of dipping rightward. The light and heavy rare-earths differentiate rather clear, $\mathrm{La}_{\mathrm{N}} / \mathrm{Yb}_{\mathrm{N}}$ is $6.32-11.92$ and $\delta \mathrm{Eu}$ is $0.17-$ 0.65 , showing strong negative Eu anomaly. From early to late, the LREE and HREE differentiation weakens and the negative Eu anomaly gets slightly stronger. Enriched in $\mathrm{K}$, $\mathrm{Th}, \mathrm{U}$, and $\mathrm{Rb}$, strongly depleted in such LILE as $\mathrm{Ba}$, and from early to late stage the depleted features weakens; weakly depleted in $\mathrm{Nb}$ and $\mathrm{Ta}$, strongly depleted in HFSEs such as $\mathrm{Sr}, \mathrm{P}$, and $\mathrm{Ti}$.

$\left({ }^{86} \mathrm{Sr} /{ }^{87} \mathrm{Sr}\right)_{i}$ is $0.70029-0.70751, \varepsilon \mathrm{Nd}(t)$ is -6.24 to -4.69 , and $\mathrm{T}_{\mathrm{DM} 2}$ is $1.31-1.43 \mathrm{Ga}$.

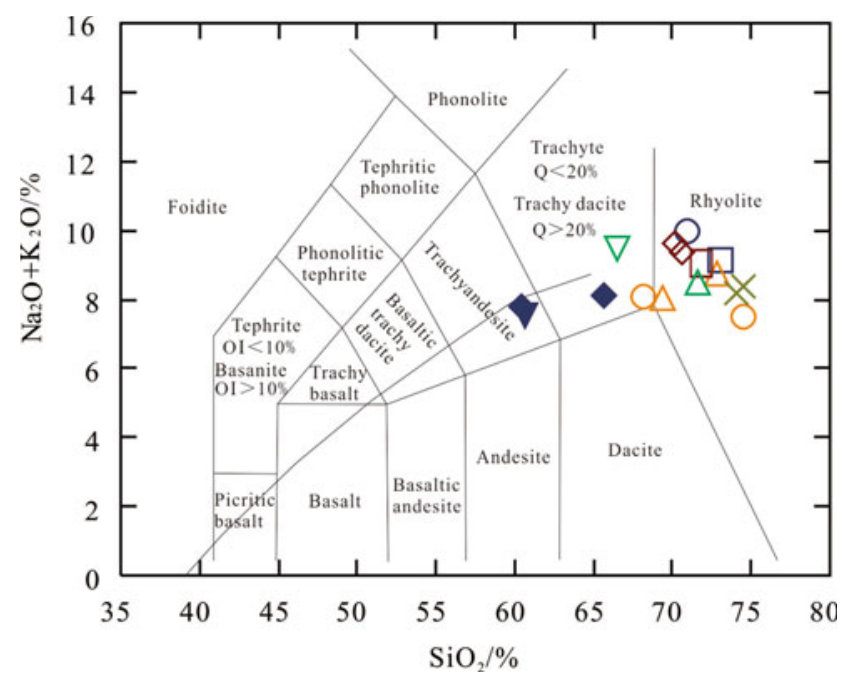

Fig. 3.80 $\mathrm{SiO}_{2}-\mathrm{Na}_{2} \mathrm{O}+\mathrm{K}_{2} \mathrm{O}$ for volcanic rocks in the survey area 


\section{Subvolcanic Rocks}

Subvolcanic rock is low in $\mathrm{SiO}_{2}$ content (60.48-65.69\%), enriched in alkali ( $\left.\mathrm{Alk}=\mathrm{K}_{2} \mathrm{O}+\mathrm{Na}_{2} \mathrm{O}, 7.46-8.09 \%\right)$, low in $\mathrm{K}_{2} \mathrm{O} / \mathrm{Na}_{2} \mathrm{O}$ ratio (1.08-1.20\%); high in $\mathrm{MgO}(1.44-2.55 \%$ ), $\mathrm{P}_{2} \mathrm{O}_{5}(0.16-0.34 \%)$, and $\mathrm{TiO}_{2}(0.58-0.83 \%)$; DI index is lower (67.26-76.94); $\mathrm{A} / \mathrm{CNK}$ is $0.84-0.94$, showing metaluminous. Rittmann Index $(\sigma)$ is $2.88-3.41$, and this means all have the features of shoshonite series.
Subvolcanic rock is high in content of $\sum$ REE $\left(202.73 \times 10^{-6}-224.14 \times 10^{-6}\right)$, and the chondrite-normalized REE patterns show a feature of weakly dipping toward right, light, and heavy rare-earth differentiate pretty obvious, $\mathrm{La}_{\mathrm{N}} / \mathrm{Yb}_{\mathrm{N}}$ is $9.78-10.32$ and $\delta \mathrm{Eu}$ is $0.51-0.68$, Eu showing medium negative anomaly. Enrichment in $\mathrm{K}, \mathrm{Th}, \mathrm{U}$, and $\mathrm{Rb}$, etc., and depletion in $\mathrm{Ba}, \mathrm{Sr}, \mathrm{P}, \mathrm{Nb}, \mathrm{Ta}$, and $\mathrm{Ti}$, etc., weaken compared with volcanic rock.
Fig. 3.81 REE

chondrite-normalized diagram and trace element primitive mantle-normalized diagram for main volcanic rocks in the survey area
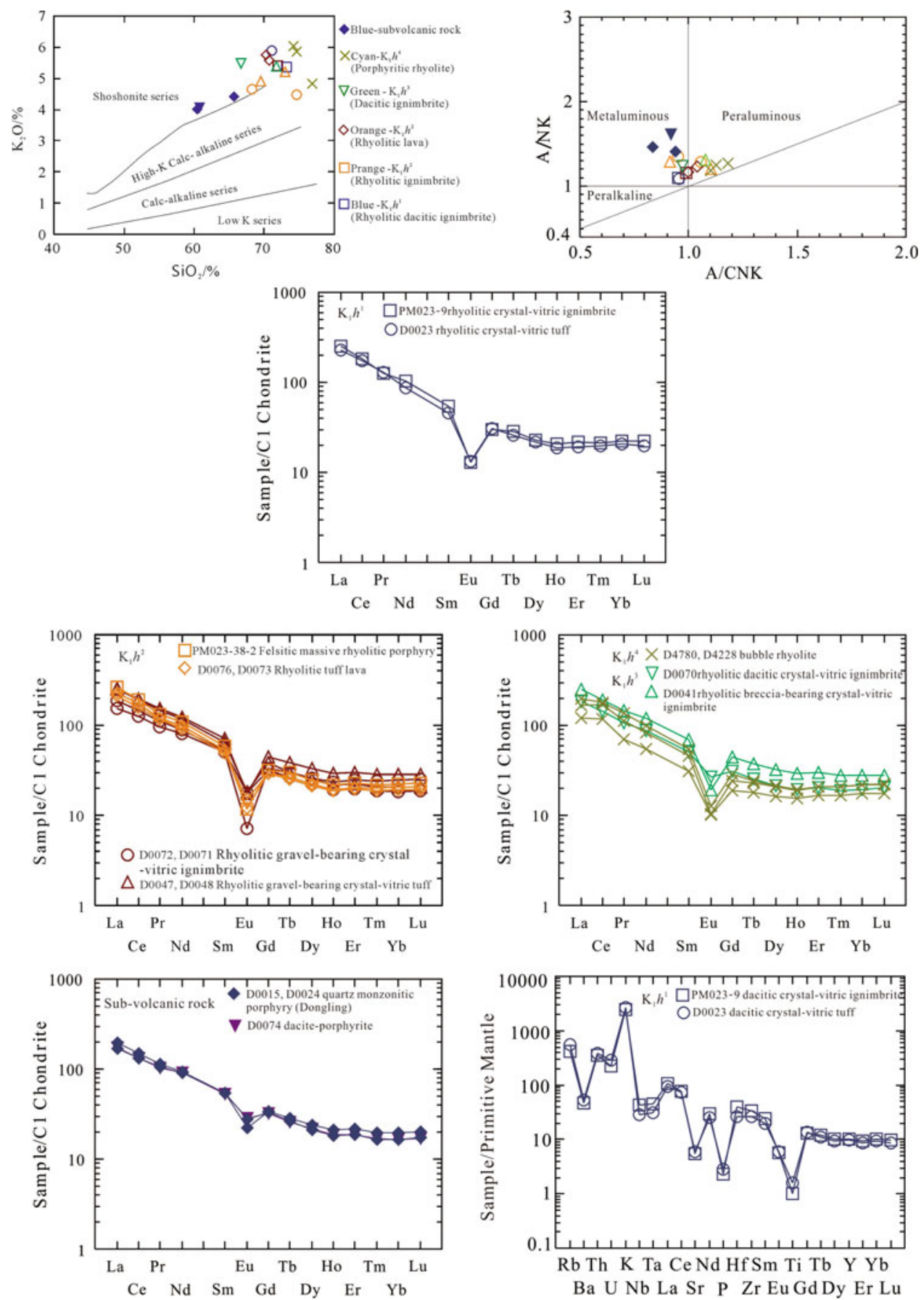
Fig. 3.81 (continued)
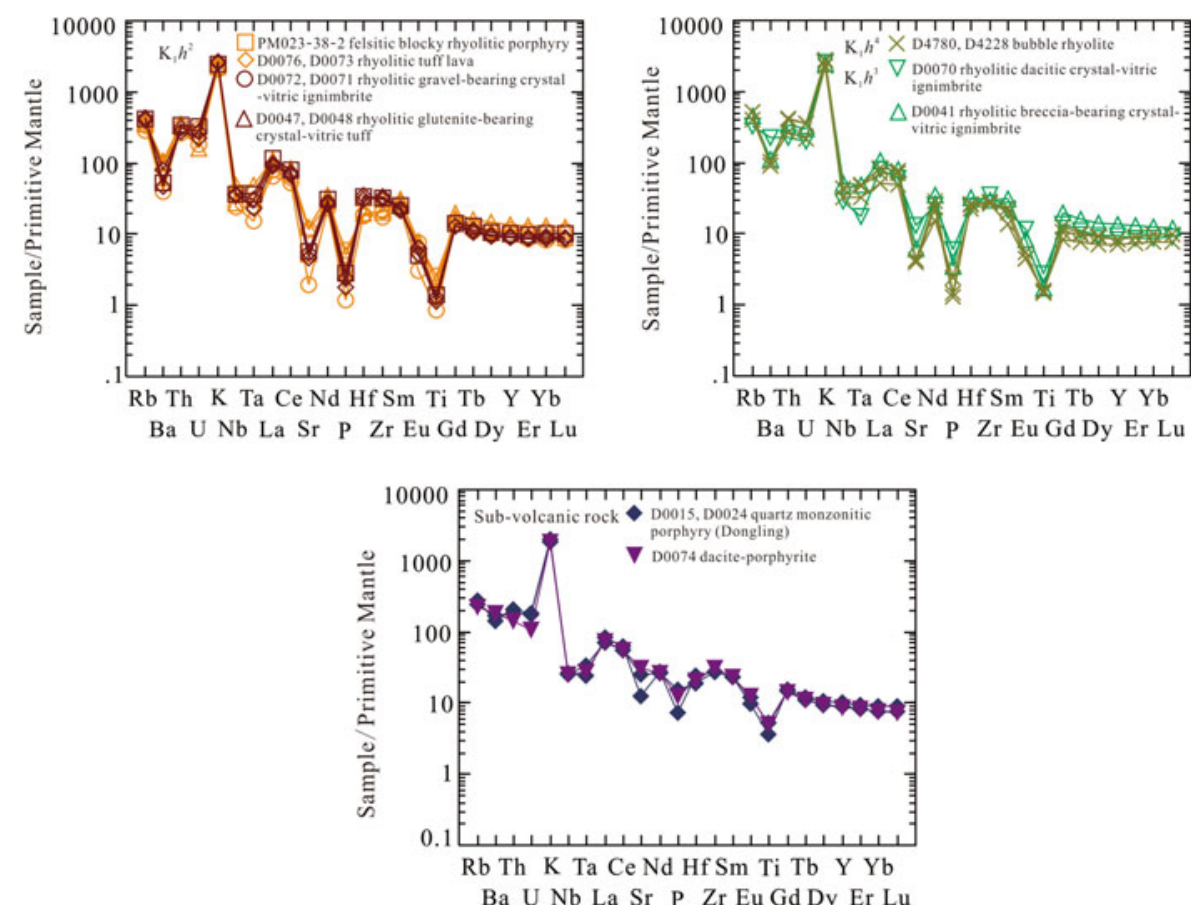

$\left({ }^{86} \mathrm{Sr} /{ }^{87} \mathrm{Sr}\right)$ is $0.70733-0.70847, \varepsilon_{\varepsilon \mathrm{Nd}}(t)$ is -5.07 to -4.55 , and $\mathrm{T}_{\mathrm{DM} 2}$ is $1.30-1.33 \mathrm{Ga}$, like other volcanic rocks in the survey area.

\subsubsection{Magmatic Source and Tectonic Setting}

Four eruptive rhythms can be divided into the survey area, based on the combination of volcanic lithologies and lithofacies as well as regional comparison. The geochemical features suggest that the early stage is a suite of shoshonite-series rhyolitic volcanic clastic rock and lava with high $\mathrm{Si}$ content $(66.68-76.90 \%)$, low $\mathrm{Sr}$ $\left(35.05 \times 10^{-6}-229.7 \times 10^{-6}\right)$, and strong negative $\mathrm{Eu}$ anomaly, the late stage is a suite of shoshonite-series volcanic rock with low $\mathrm{Si}(60.48-65.69 \%)$, relative high $\mathrm{Sr}$ $\left(225.0 \times 10^{-6}-551.4 \times 10^{-6}\right)$ and medium negative $\mathrm{Eu}$ anomaly, and volcanic clastic rock and lava are relatively lower in content of $\mathrm{Ti}, \mathrm{Co}$, and $\mathrm{Ni}$ than subvolcanic rock, from early volcanic clastic rock and lava eruption to late intrusion of volcanic rock, the components between both change apparently from high $\mathrm{Si}$, low $\mathrm{Sr}$ content and high differentiation to low $\mathrm{Si}$, relatively high $\mathrm{Sr}$ and low differentiation (Fig. 3.82), which may reflect that differentiation evolution of magma in the upper horizon is lower than that in the bottom horizon, in Tianmu Mount, component zonation exists in magma chamber, highly differentiate magma concentrate at the top of magma chamber to be erupted early, and such component zonation in magma chamber is pretty universal in Late Mesozoic volcanic rock in southeast coastal regions (Xing et al. 2009).
For (sub) volcanic rock series, $\left({ }^{86} \mathrm{Sr} /{ }^{87} \mathrm{Sr}\right)_{\mathrm{i}}$ is 0.70029 0.70847 with average value of $0.70566 ; \varepsilon \mathrm{Nd}(t)$ is -6.24 to -4.55 , with average value of -5.05 , and $\mathrm{T}_{\mathrm{DM} 2}(\mathrm{Nd})$ is 1.30 $1.43 \mathrm{Ga} ; \varepsilon \mathrm{Nd}(t)$ is significantly higher than $\varepsilon \mathrm{Nd}(t)(-8.12$ to -9.06) of lithospheric mantle in the north margin of Yangtze block (Xue et al. 2009); the $\mathrm{T}_{\mathrm{DM} 2}(\mathrm{Nd})$ also significantly lower than the peak age (1.6-1.7 Ga) of crust-source-type granite of Yanshanian in South China ( $\mathrm{Li} 1993)$ and the $\mathrm{T}_{\mathrm{DM} 2}(\mathrm{Nd})$ of basement metamorphic rocks in southwest of Yangtze block $(2.0 \mathrm{Ga})$ and Cathaysian orogeny $(1.8-2.2 \mathrm{Ga})$ (Che and Jiang 1999), indicating the magmatic source area may be the place where the lithospheric mantle of Yangtze block and ancient crust materials are mixed because there are clear crust-mantle interaction and addition of juvenile mantle materials in volcanic rock of Tianmu Mount.

Similar to the intrusive rock series and the volcanic-intrusive rock series in the survey area, intrusive (sub) volcanic rock series in the survey area belongs to the post-collision granite in the $\mathrm{Rb}-\mathrm{Y}+\mathrm{Rb}$ diagram (Fig. 3.45), and also largely belongs to the later orogeny and post-orogeny areas in the $R_{1}-R_{2}$ diagram. The (sub) volcanic-intrusive rock series are the product of intracontinent stretching after subduction orogeny in Cretaceous epoch, according to the geochemical and chronological features.

\subsubsection{Volcanic Activity and Metallogenesis}

In the survey area, volcanism and intrusion are developed well, and metallogenesis related to volcanic activity is much 

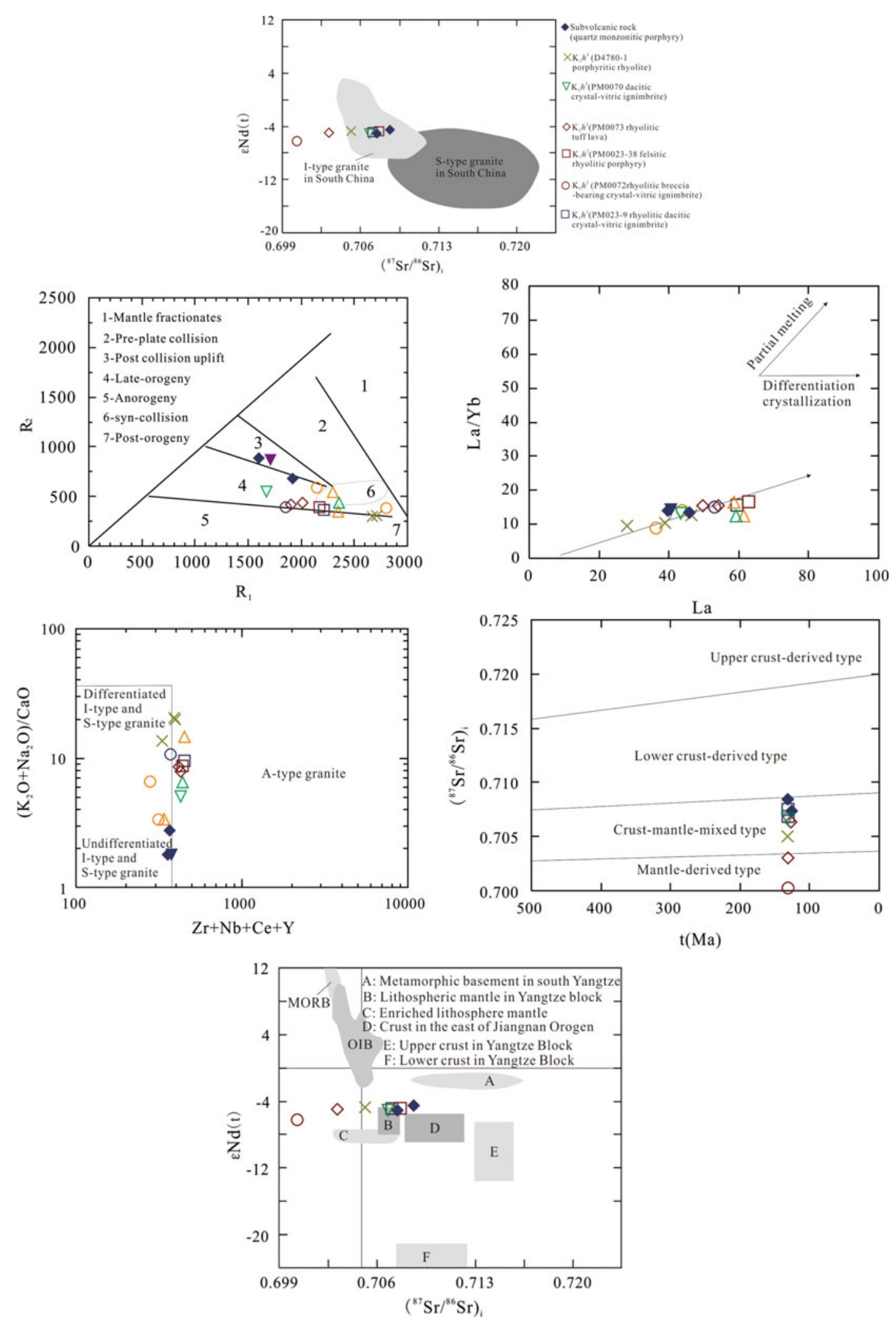

Fig. 3.82 Discrimination diagrams of volcanic rock types and tectonic setting in the survey area 
weaker compared to intrusive activities. The reasons are that (1) volcanic activity mainly acts within the early depression basin where there is no wall rocks related to metallogenesis; (2) the product of volcanic eruption crystallizes fast, and there is no plenty of ore-forming fluids. Therefore, in the field survey, a handful of $\mathrm{Zn}-\mathrm{Pb}$ and fluorite mineralization developed in fractures are casually seen. However, in the survey area, uranium ore occurrences are developed in rhyolitic porphyry of Mogan Mount, in the east periphery of the survey area. Volcanic structures and plenty of lava outcrops are developed, so in the future exploration and research should be focused on metallogenesis associated with volcanic structures. In addition, in the survey area, exogenous mineral resources associated with volcanic rock are mainly bentonite, kaolin, and clay minerals, which developed in ignimbrite and lava, in lamellar shape, and are worth prospecting.

\subsection{Vein Rocks}

\subsubsection{Distribution Features}

In the survey area, vein rocks are widely distributed, and areas for sedimentary strata, intrusive rocks and volcanic rocks have developed veins to different degrees, and there are various types of attitudes, mainly NW-strike and NW-strike, secondly NNE-strike, nearly SN strike and nearly EW strike, etc.; there are totally 194 veins, of which 59 are in sedimentary rock areas, 60 in intrusive rock areas, and 75 in volcanic rock area.

\subsubsection{Rock Types}

Veins have complex lithologies, followed by granite porphyry, granite, aplite, felsite, rhyolitic porphyry, andesite, andestic porphyrite, diorite, dacite, dacite-porphyrite, orthophyre, diabase, sillite, and lamprophyre, etc., which generally show the feature of transition from acid to neutral and basic. Main geological features of vein rocks are described in Table 3.4.

\section{Granitic porphyry}

Widely developed within Ma'anshan pluton, NE-strike intruded in monzonitic granite and syenogranite (Fig. 3.83), the dipstrike of the intrusive contact is $310^{\circ}-330^{\circ} \angle 50^{\circ}-80^{\circ}$, borderline is straight, flat, and clear; veins are $1-10 \mathrm{~km}$ long and 10-100 m wide. Porphyritic texture, phenocryst unevenly distributed, mainly K-feldspar (3-10\%), quartz (3-5\%), plagioclase (3-5\%), and a handful of biotite, generally in the grain size of $0.6-1.5 \mathrm{~mm}$, less up to about $2 \mathrm{~mm}$. Matrix: feldspar and quartz, mostly in the micro-grained shape, hidden graphic texture seen locally, generally in the grain size $<0.5 \mathrm{~mm}$.

\section{Pegmatite}

Granitic pegmatite, the vast distributed in Ma'anshan and Xianxia plutons, mainly lump and lentoid, the former diameter is just $50 \mathrm{~cm}$, and the latter is generally not in a large scale, $30-50 \mathrm{~cm}$ long and $8-15 \mathrm{~cm}$ wide. The lentoid pegmatite in fine-grained syenogranite at Guocun transitions from coarse-grained and medium-grained syenogranite to fine-grained syenogranite, but there is no zonation on vein body itself, composed of pegmatitic-shaped Na-feldspar, quartz and a handful of biotite (Fig. 3.83), fine-grained syenogranite, feldspar quartz, and quartz zones can be seen in the outer contact zone of some vein bodies.

\section{Dioritic porphyrite}

Mostly inside Xianxia pluton, showing cyan-gray, a number of veins are arranged nearly in parallel and intruded as a high
Table 3.4 Main geological features of vein rocks in the survey area

\begin{tabular}{|c|c|c|c|}
\hline Area & Lithology & Intrusive age & Lithological features \\
\hline Ma'anshan & $\begin{array}{l}\text { Granite } \\
\text { porphyry }\end{array}$ & $\begin{array}{l}127.3 \pm 1.8 \mathrm{Ma} \\
\text { LA-ICP-MS } \\
\text { Zircon U-Pb }\end{array}$ & $\begin{array}{l}\text { NE-strike of } 40^{\circ}-60^{\circ} \text {, mostly dipping northwest, and a } \\
\text { few dipping southeast, at the dip angle of } 50^{\circ}-80^{\circ} ; 1- \\
10 \mathrm{~km} \text { long and } 10-100 \mathrm{~m} \text { wide per vein. Porphyritic } \\
\text { structure, phenocryst: quartz }(10 \%) \text {, K-feldspar }(10 \%) \text {, } \\
\text { plagioclase }(5 \%) \text {, and a handful of biotite, with grain } \\
\text { size of } 0.6-1.5 \mathrm{~mm} \text {, and up to } 2 \mathrm{~mm} \text { for a few. Matrix: } \\
\text { feldspar and quartz, mostly in the micro-gained shape, } \\
\text { generally with the grain size }<0.5 \mathrm{~mm}\end{array}$ \\
\hline Xianxia & Diabase & $\begin{array}{l}128.3 \pm 2.4 \mathrm{Ma} \\
\text { LA-ICP-MS } \\
\text { Zircon U-Pb }\end{array}$ & $\begin{array}{l}\text { Veins are prettily developed, granitic vein is the most } \\
\text { common, vein strikes vary from NE to SW differently, } \\
\text { more veins are NE-strike of } 20^{\circ}-60^{\circ} \text {, mostly dipping } \\
\text { southeast, less dipping northwest, dip angle of } 50^{\circ}-80^{\circ} \text {; } \\
\text { veins are mainly } 1.5-3 \mathrm{~m} \text { wide, a few up to } 50 \mathrm{~m} \text { wide; } \\
\text { it is } 0.2-1 \mathrm{~km} \text { long per vein }\end{array}$ \\
\hline $\begin{array}{l}\text { West } \\
\text { Tianmu }\end{array}$ & Diabase & $\begin{array}{l}130.3 \pm 1.1 \mathrm{Ma} \\
\text { LA-ICP-MS } \\
\text { Zircon U-Pb }\end{array}$ & $\begin{array}{l}\text { NW-strike or nearly EW strike intruded in porphyritic } \\
\text { rhyolite, it is generally } 10-100 \mathrm{~m} \text { long, } 0.1-1 \mathrm{~m} \text { wide, } \\
\text { dipping } 0-10^{\circ} \text {, and at the dip angle of } 75^{\circ}-80^{\circ}\end{array}$ \\
\hline
\end{tabular}




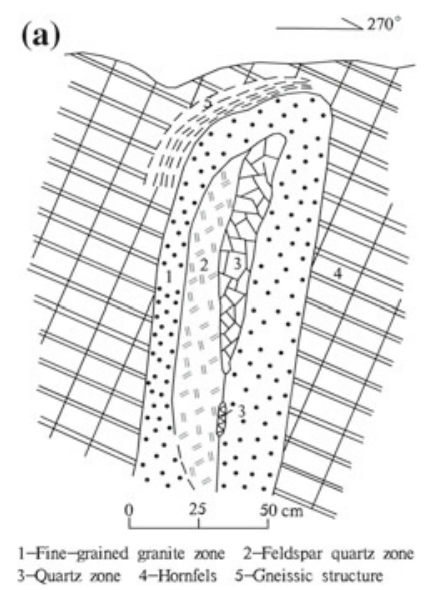

(b)

(c)
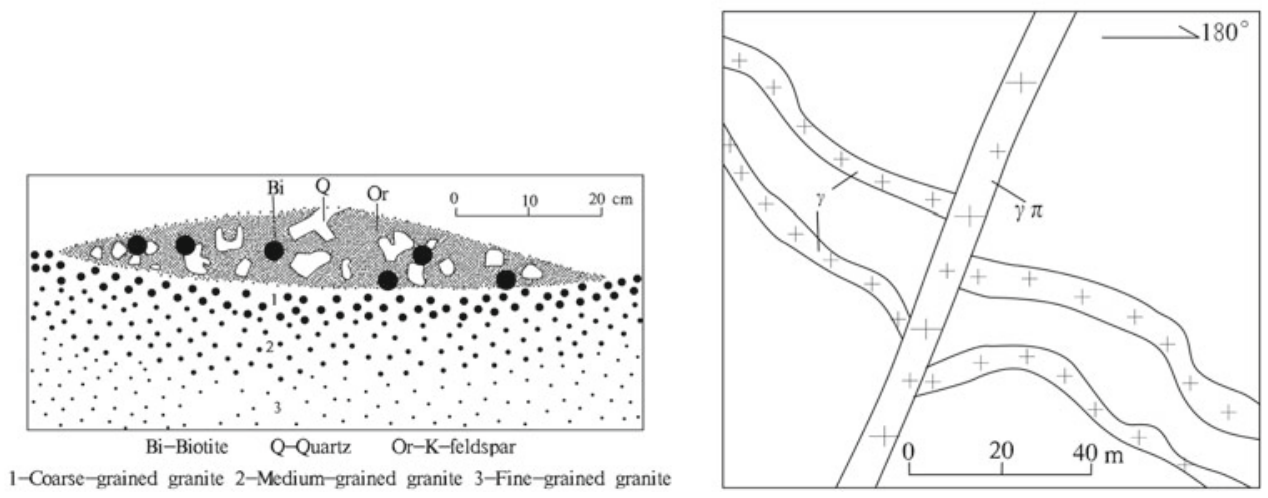

Fig. 3.83 a, b Outcropping sketch and zonation diagram of granite pegmatite inside Ma'anshan composite pluton; $\mathbf{c}$ fine-grained syenogranite vein cut off by granite porphyry inside Ma'anshan composite pluton

angle $\left(15^{\circ} \angle 75^{\circ}\right)$ into monzonitic granite (Fig. 3.84). The rocks are strongly weathered, and spheroidal weathering can be seen. The weathering spheroid varies in size, generally $15 \mathrm{~cm} \times 25 \mathrm{~cm}$, in the shape of ellipse.

\section{Diabase}

Mostly developed in Xianxia pluton and volcanic rock, for instance, diabase vein in porphyritic rhyolite at West Tianmu Mount is about $10-100 \mathrm{~m}$ long, $10-100 \mathrm{~cm}$ wide and $10^{\circ} \angle 85^{\circ}$ in dipstrike. The diabase vein is wide in its east, and narrow in its west, and the contact surface is generally flat, straight, and clear. A very handful of plagioclase phenocryst is seen in rock locally, as with a few quartzs, and phenocryst is $1-3 \mathrm{~mm}$ in size. There are numerous pores on the vein surface, which are directionally arranged, in the size of $1-5 \mathrm{~mm}$, with its dipstrike similar to the veins.

\subsubsection{Geochronological Features}

Zircon LA-ICP-MS U-Pb geochronological research is conducted on granitic porphyry vein (D0034) in Ma'anshan pluton, diabase veins in Xianxia pluton (D0013) and West Tianmu Mount porphyritic rhyolite (D4235). In granitic porphyry, zircon is mostly irregular long and short column, with the length of 50-200 $\mu \mathrm{m}$, and the length-width ratio is about $3: 1-1: 1$, showing obvious oscillatory zoning. In diabase,
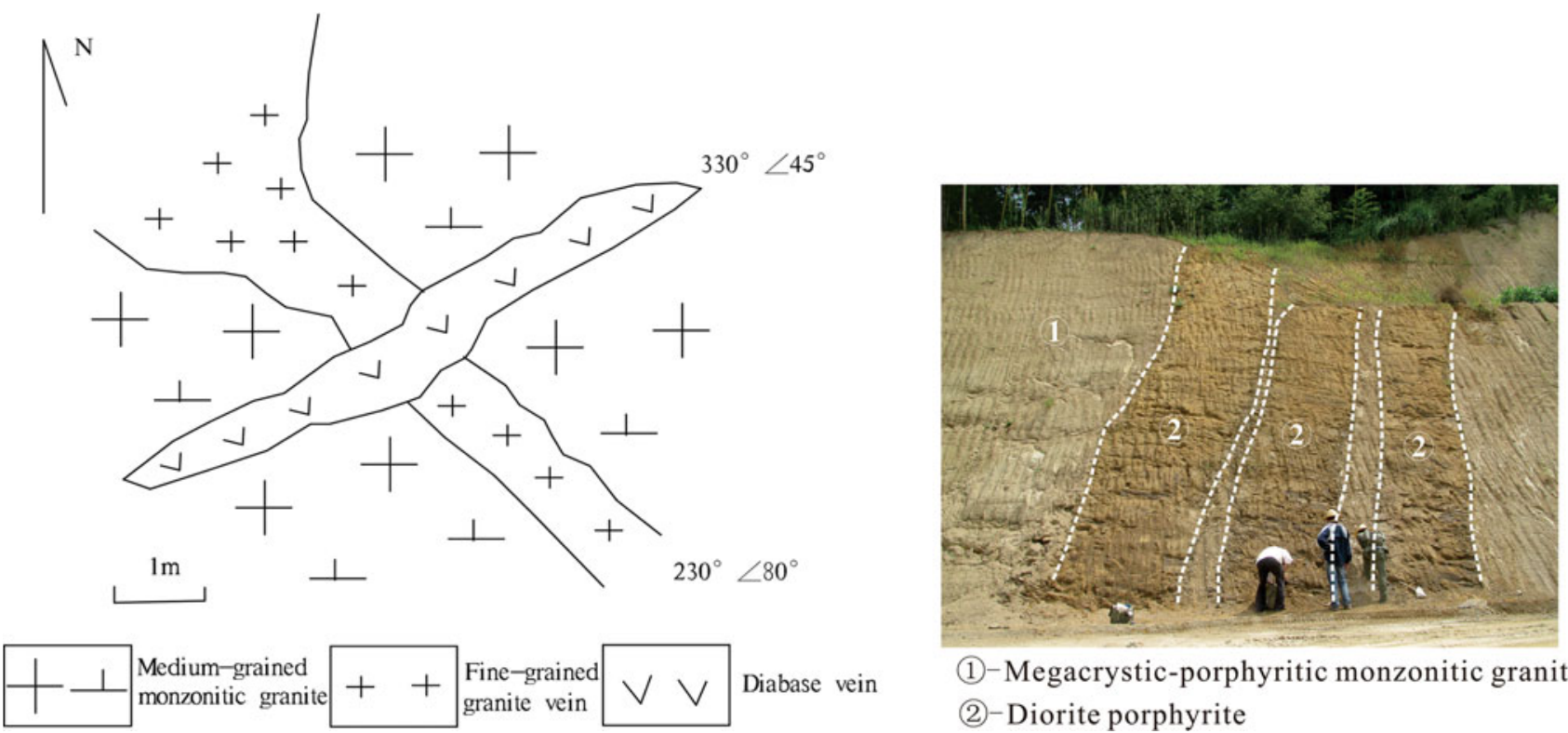

(1)-Megacrystic-porphyritic monzonitic granite

(2)-Diorite porphyrite

Fig. 3.84 Outcropping features of veins inside Xianxia composite pluton 
zircon is mostly irregular long and short columns, with the length of $60-100 \mu \mathrm{m}$, the length-width ratio of $1.5: 1-1: 1$, and also contains oscillatory zoning.

$\mathrm{U}$ content in zircon is $122 \times 10^{-6}-836 \times 10^{-6}$, $83 \times 10^{-6}-1717 \times 10^{-6}$, and $51 \times 10^{-6}-336 \times 10^{-6}$, respectively, Th is $97 \times 10^{-6}-349 \times 10^{-6}, 11 \times 10^{-6}-$ $914 \times 10^{-6}$, and $8 \times 10^{-6}-84 \times 10^{-6}$, respectively, and $\mathrm{Th} / \mathrm{U}$ ratio is $0.54-1.62,0.03-1.92$, and $0.11-0.35$, respectively, showing a typical feature of magmatic zircon. Sample locations mostly are projected on or near the concordant curve, $206 \mathrm{~Pb} / 238 \mathrm{U}$ weighted mean age is, respectively, $127.4 \pm 1.8 \mathrm{Ma} \quad($ MSWD $=0.77), \quad 128.3 \pm 2.4 \mathrm{Ma}$ $(\mathrm{MSWD}=2.8)$, and $130.3 \pm 1.1 \mathrm{Ma} \quad(\mathrm{MSWD}=1.12)$ (Fig. 3.85), representing the overall intrusive age of veins in the survey area (130.3-127.4 Ma).

\subsubsection{Geochemical Features and Origin of the Vein Rocks}

\section{Geochemical Features}

\section{Granitic porphyry}

(1) The content of $\mathrm{SiO}_{2}, \mathrm{MgO}, \mathrm{CaO}, \mathrm{Na}_{2} \mathrm{O}+\mathrm{K}_{2} \mathrm{O}, \mathrm{P}_{2} \mathrm{O}_{5}$, and $\mathrm{TiO}_{2}$ is $76.74 \%, 0.21 \%, 0.40,8.04 \%, 0.02 \%$, and 0.07 , respectively.
(2) Rittmann Index $(\sigma)$ is 1.92 , within the range of high $\mathrm{K}-$ $\mathrm{Ca}$ alkaline series.

(3) Peraluminous, A/CNK is 1.14.

(4) $\sum \mathrm{REE}$ is low, $\sum \mathrm{REE}=122.78 \times 10^{-6}$, LREE/HREE $=$ 3.47, and the chondrite-normalized REE patterns show a feature of "V" shape. The light and heavy rare-earth differentiate unobviously, and $\mathrm{Eu}$ anomaly is obvious $(\delta \mathrm{Eu}=0.21)$.

(5) The trace element spider diagram indicates enrichment in LILEs such as $\mathrm{K}$, Th, $\mathrm{U}$, and $\mathrm{Rb}$, but strongly depleted in elements such as $\mathrm{Ba}$; strongly depleted in HFSEs such as Sr, P, Nb, and Ti (Fig. 3.86).

\section{Diabase}

(1) The content of $\mathrm{SiO}_{2}, \mathrm{MgO}$, and $\mathrm{CaO}$ is $47.66-48.44 \%$, $3.32-3.53 \%$, and 5.41-6.19\%, belonging to trachy basalt and tephrite in the TAS diagram, alkaline basalt in the $\mathrm{Nb} / \mathrm{Y}-\mathrm{Zr} /\left(10000 \mathrm{TiO}_{2}\right)$ diagram.

(2) $\mathrm{Na}_{2} \mathrm{O}+\mathrm{K}_{2} \mathrm{O}$ content is 5.49-6.87\%, Rittman index $(\sigma)$ is 5.54-10.13, within the area for shoshonite series.

(3) Metaluminous, $\mathrm{A} / \mathrm{CNK}$ is $0.84-0.86$, the content of $\mathrm{P}_{2} \mathrm{O}_{5}$ and $\mathrm{TiO}_{2}$ is $0.41-0.54 \%$ and $2.14-2.23 \%$.

(4) $\sum \mathrm{REE}$ is moderate, $\sum \mathrm{REE}=174.98 \times 10^{-6}$ $179.48 \times 10^{-6}$, showing enrichment in LREE, and LREE and HREE differentiate obviously, LREE/HREE $=7.93-7.95$. The chondrite-normalized
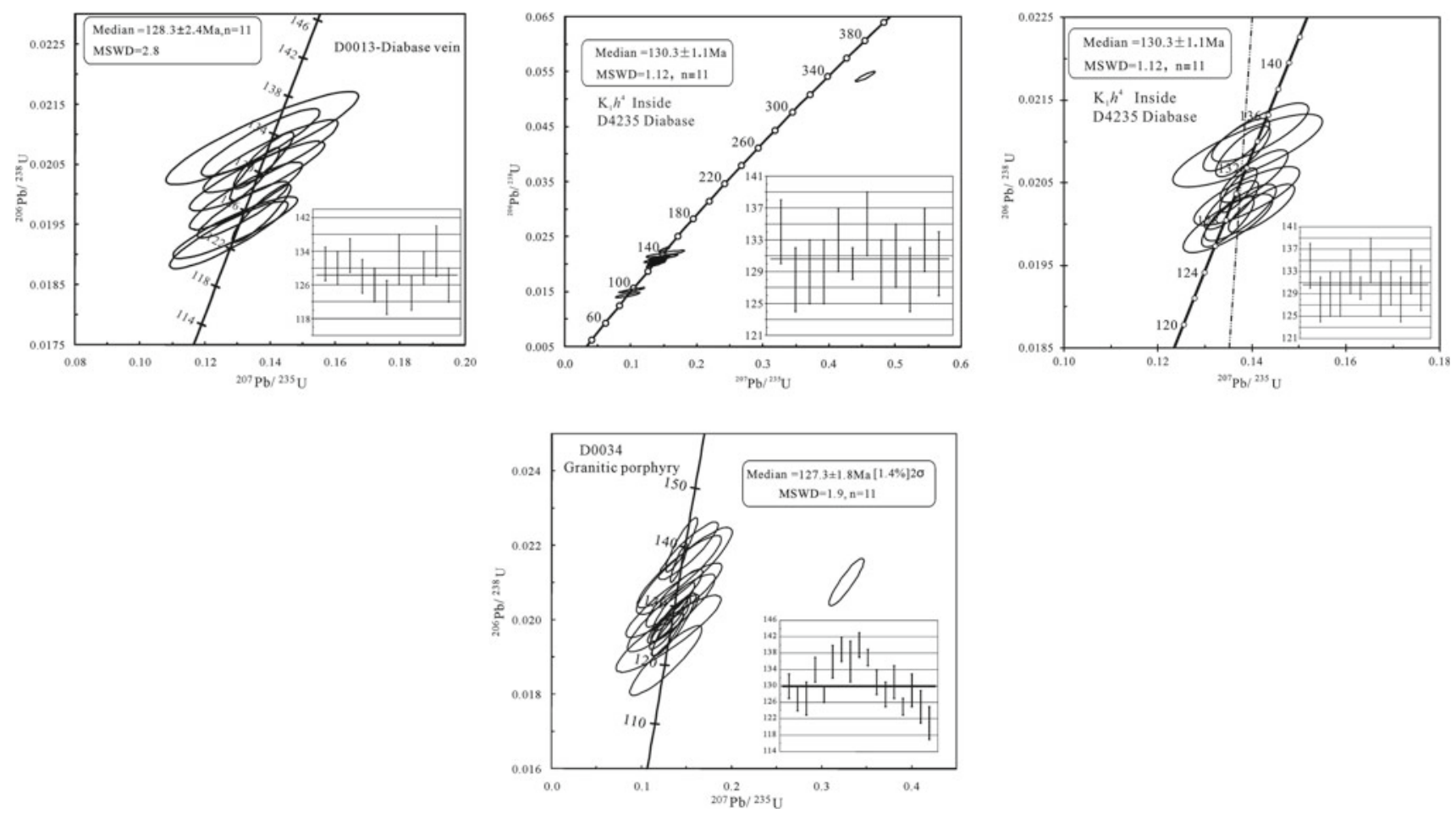

Fig. 3.85 Zircon $\mathrm{U}-\mathrm{Pb}$ concordia diagrams and age histograms for vein rocks in the survey area 

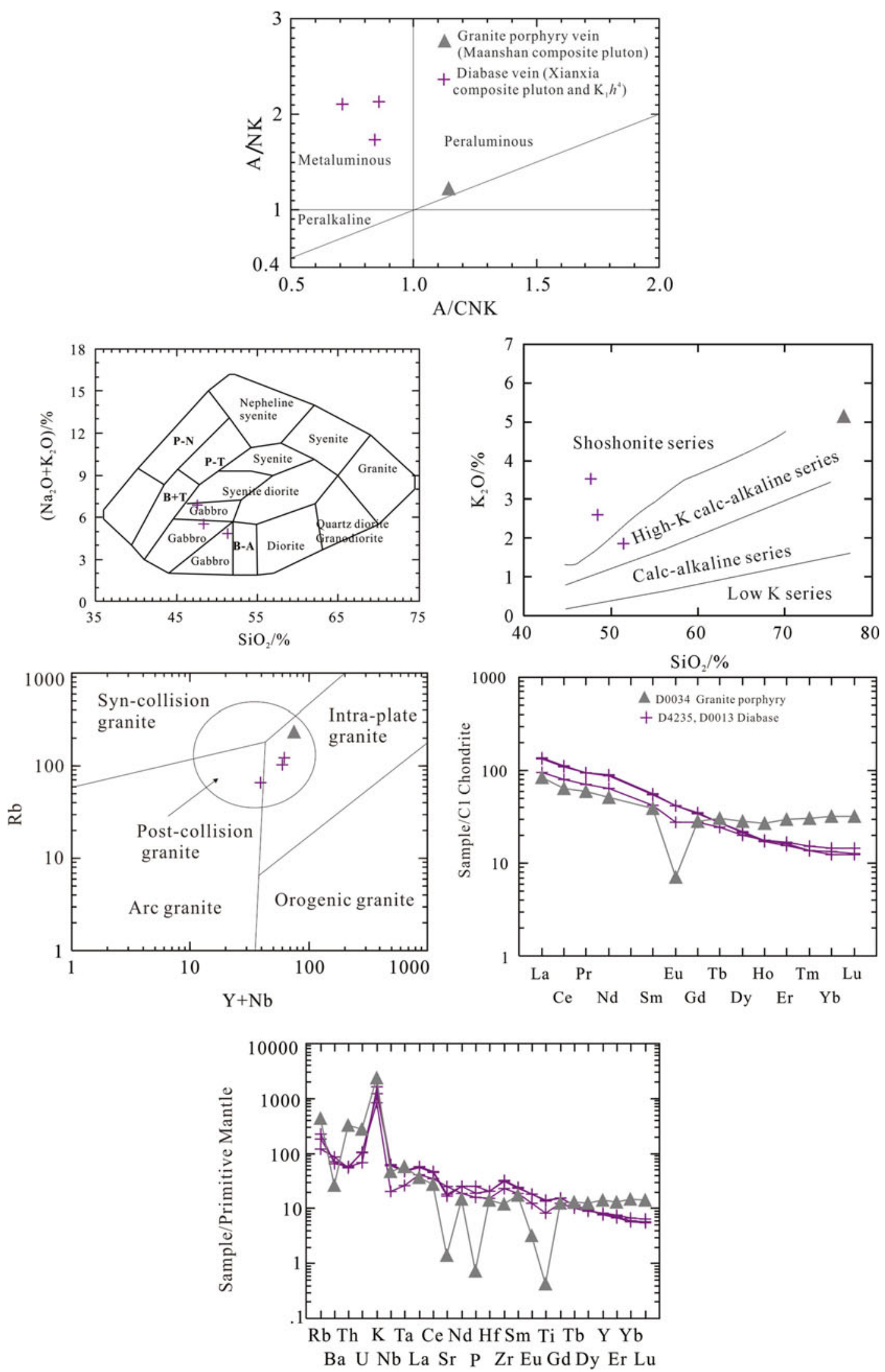

Fig. 3.86 Geochemical feature and discrimination diagram of main rock veins in the survey area 

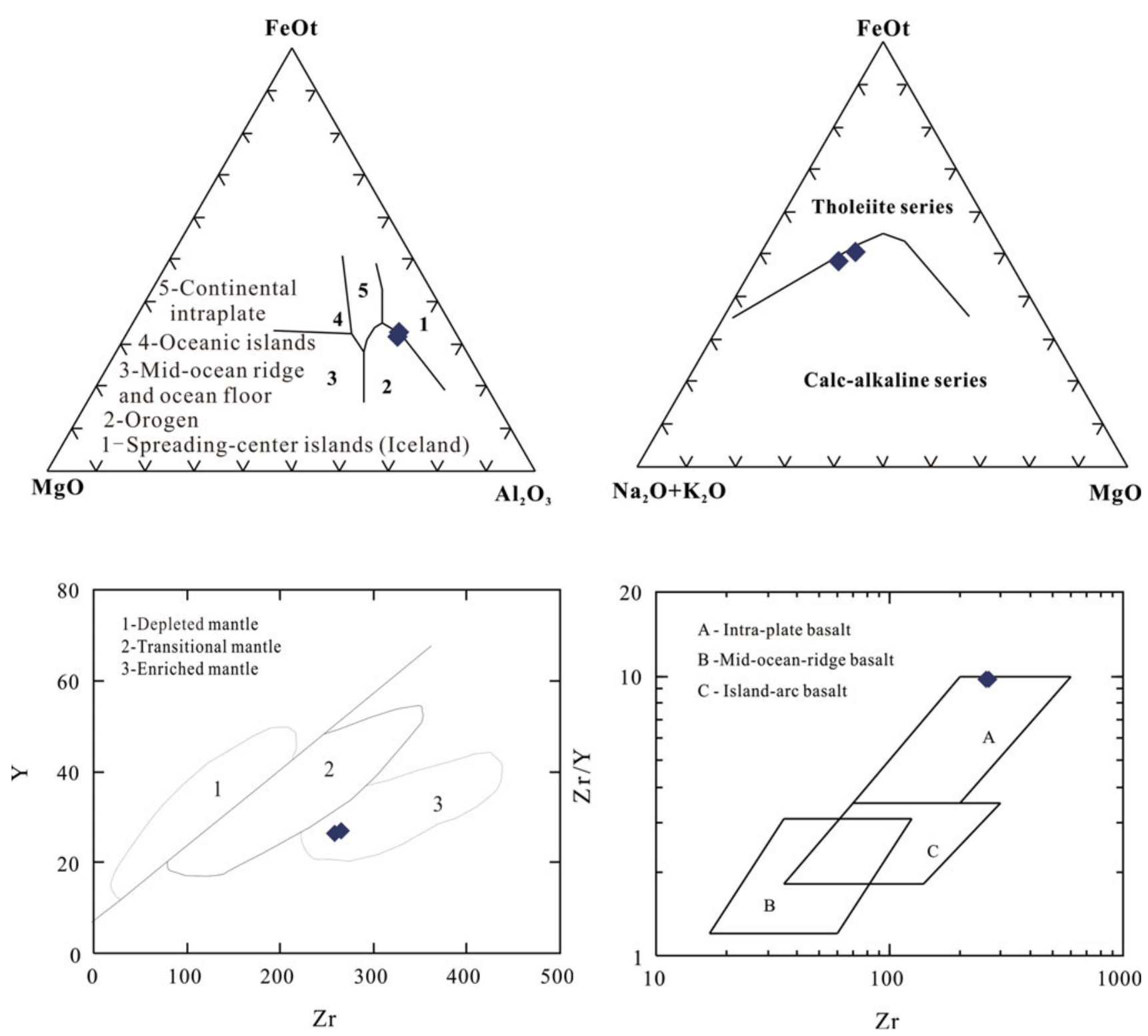

Fig. 3.87 Geochemical discrimination diagram of selective diabase veins in the survey area

REE patterns generally show the feature of dipping rightward, nearly no $\mathrm{Eu}$ anomaly $(\delta \mathrm{Eu}=0.91-0.95)$ and $\mathrm{Ce}$ anomaly $(\delta \mathrm{Ce}=0.95-0.96)$.

(5) The trace element spider diagram indicates enrichment in LILE such as Rb and K, and slightly weakly depleted in elements such as $\mathrm{Ba}, \mathrm{Th}, \mathrm{U}$, and $\mathrm{Sr}$.

\section{Origin of the vein rocks}

In the survey area, vein rocks formed close to or slightly later than the intrusion of volcanic rock and intrusive rocks, but all occurs in Early Cretaceous, and belong to the granitic area of post-collision plate in the $\mathrm{Rb}-\mathrm{Y}+\mathrm{Rb}$ diagram, products of intracontinent stretching after subduction orogeny in Cretaceous. Especially, diabase showing obvious relative HFSE deficit suggests that the enrichment of lithospheric mantle components is related to the modification of subducting slabs, and such enriching mantle-derived feature possibly records early modification of subducting slabs but also is the result of subduction of contemporaneous plates. The $\mathrm{Zr} / \mathrm{Y}-\mathrm{Zr}$ diagram shows that all diabases belong to the intraplate environmental area (Fig. 3.87), suggesting that diabase magma does not from island arc or active continental margin, and the enriching mantle-derived feature indicated by it possibly succeeds mainly the early modification record of subducting slabs.

Meanwhile, a series Early Cretaceous tensile red fault depression basins were developed in southeast China, indicating since the Early Cretaceous it had been regionally in the background of lithosphere expansion. In south China, 
from early to late stage (140-70 Ma) of the Late Mesozoic, diabase veins had been widespread for multiple periods, which also indicates the then background of intense crust tension, and such crust tension has the feature of episodic activity that is transitioned from local regions in the early stage (e.g., 140 Ma mainly happened in north Guangdong and west Fujian) to holistic tension in the late stage (since $94 \mathrm{Ma}$ ). Diabase vein rocks formed under the expansional background are widely distributed in west Fujian, coastal areas of Fujian, Hainan, Jiangxi, and Zhejiang, etc., a product from the joint melting of lithospheric mantle and convective asthenosphere.

\subsection{Comparison Between Intrusion and Volcanism}

\subsubsection{Time and Space Relationship}

According to the patterns of magmatism, magmatite in the survey area is divided into three series: intrusive rock, volcanic-intrusive rock, and (sub)volcanic rock, and their metallogenic time limits are 145.1-125.0 Ma, 130.5127.7 Ma, and 135.2-125.4 Ma, respectively, all in the beginning of Early Cretaceous. Intrusive rocks are mainly developed at the margins of NE-strike faults, folds, and volcanic depressions, Ma'anshan pluton is mainly under control of the NE-strike, Tongkengcun-Qiguancun fault and Tangshe pluton are mainly under control of the NE-strike, Wangjia-Tangshecun anticline fold while Xianxia, Tonglizhuang, and Wushanguan plutons intruded around the margin of volcanic depressions, and their formation is closely related to basin-control structures in volcanic depressions. Volcanic-intrusive rock is mainly developed at the margin of early intrusive rock and volcanic depressions as well as in volcanic rocks; volcanism-subvolcanism is mainly under control of volcanic depressions. Overall, in the survey area, intrusion is a little earlier than volcanism, featuring migration from west to east, and there is close time-space relationship in terms of rock-control and basin-control structures.

\subsubsection{Origin Relationship}

In the survey area, product of intrusive rock is mainly acidic, followed by monzonitic granite-syenogranite; the volcanic-intrusive product is mainly intermediate acidic, followed by quartz diorite-quartz syenite-quartz monzonite-syenogranite; (sub) volcanic product is mainly intermediate acid-neutral, followed by rhyolitic dacitic-rhyolitic ignimbrite, lava, quartz monzonitic porphyry, and rhyolitic porphyry, etc. Evolution processed showing as acidic $\rightarrow$ intermediate acid $\rightarrow$ neutral and metaluminous $\rightarrow$ weakly $\quad$ peraluminous $\rightarrow$ (maluminous $\rightarrow$ metaluminous) from early to late stage; products of these three rock types show the feature of high differentiation evolution, and only the DI index of the volcanic rock is lower. The detailed characteristics of the Early Cretaceous magmatic rocks is listed in Table 3.5.

\subsubsection{Comparison with Magmatite in Neighboring Areas}

Based on the reliable dating data in recent 10 years, it is known that Yanshanian intrusive rocks in northwestern Zhejiang and neighboring areas were mainly formed in Middle Jurassic-Early Cretaceous (168-124 Ma), concentrated in three stages: $168-163 \mathrm{Ma}, 150-147 \mathrm{Ma}$, and 142$124 \mathrm{Ma}$. The age trends to become young toward northeast, and in Late Cretaceous, small-scale magmatic activities occurred at 118-115 Ma locally.

In general, rocks were formed earlier in western Zhejiang, for instance, granodiorite at Tongcun formed at $162.1 \mathrm{Ma}$ (Zhu et al. 2014), and the magmatic source is dominated by the lower crust, and crystallization differentiates weakly. However, in plutons located in neighborhoods in Zhejiang and Anhui, the mantle-derived materials increase, which belongs to crust-mantle-mixed area where crystallization differentiates strongly (Fig. 3.88). From Middle and Late Jurassic to Early Cretaceous, the tectonic setting of intrusive rocks evolved from collision-arc granite to intraplate granite. The diversity and changes in magmatic source also demonstrated the changes in subduction angle of paleo-Pacific-plate, transformation from subduction and extrusion orogeny in the Middle-Late Jurassic to expansion and tension in the beginning of Early Cretaceous, which resulted in different contributions of lithospheric mantle of Yangtze block and crust material source areas in Jiangnan Orogen, and differentiation of magma crystallization.

For volcanic basins developed in Late Mesozoic in northwestern Zhejiang and its surrounding, the main body of its volcanic rock strata is the lower volcanic rock series, and a handful of upper volcanic rock series, and bordering with the nearly EW-strike Changhua-Hangzhou Fault, it can be divided into two volcanic rock areas: Shunxi-Huzhou and Changshan-Tonglu. In Shunxi-Huzhou volcanic rock area, outcropped volcanic rock is mainly Huangjian Formation $\left(\mathrm{K}_{1} h\right)$ and a handful of Laocun Formation $\left(\mathrm{K}_{1} l\right)$ of lower volcanic rock series Jiande Group, and on the basis of zircon $\mathrm{U}-\mathrm{Pb}$ age analysis on volcanic basins of Tianmu Mount, Huangjian Formation is erupted in 135-125 Ma, the beginning of Early Cretaceous. In Changshan-Tonglu volcanic rock area outcropped strata are mainly Laocun Formation $\left(\mathrm{K}_{1} l\right)$, Huangjian Formation $\left(\mathrm{K}_{1} h\right)$, Shouchang Formation 
Table 3.5 Feature comparison of magmatism of the Early Cretaceous in the survey area

\begin{tabular}{|c|c|c|c|}
\hline Series & Intrusive rock series & $\begin{array}{l}\text { Volcanic-intrusive rock } \\
\text { series }\end{array}$ & (Sub) volcanic rock series \\
\hline $\begin{array}{l}\text { Location and } \\
\text { rock-control } \\
\text { structure }\end{array}$ & $\begin{array}{l}\text { Paleozoic stratum area; } \\
\text { NE-strike fault, folds, and } \\
\text { the margin of volcanic } \\
\text { depressions }\end{array}$ & $\begin{array}{l}\text { Margin of early intrusive } \\
\text { rocks and volcanic } \\
\text { depressions, as well as } \\
\text { inside of volcanic lava }\end{array}$ & $\begin{array}{l}\text { Inside of volcanic } \\
\text { depressions, and fracture } \\
\text { at the basin margin }\end{array}$ \\
\hline $\begin{array}{l}\text { Lithological } \\
\text { combination }\end{array}$ & $\begin{array}{l}\text { Monzonitic granite - } \\
\text { syenogranite }\end{array}$ & $\begin{array}{l}\text { Quartz diorite-quartz } \\
\text { syenite-quartz } \\
\text { monzonite-syenogranite }\end{array}$ & $\begin{array}{l}\text { Ignimbrite, lava, quartz } \\
\text { monzonitic porphyry and } \\
\text { rhyolitic porphyry }\end{array}$ \\
\hline $\begin{array}{l}\text { Major } \\
\text { elements } \\
\text { geochemical } \\
\text { features }\end{array}$ & $\begin{array}{l}\text { (1) Acid } \\
\text { (2) Metaluminous } \\
\text { (3) High K calc-alkaline } \\
\text { series } \\
\text { (4) Low } \rightarrow \text { high } \\
\text { differentiation }\end{array}$ & $\begin{array}{l}\text { (1) Intermediate acid } \\
\text { (2) Weakly peraluminous } \\
\text { (3) Shoshonite series } \\
\text { (4) Moderate } \\
\text { differentiation }\end{array}$ & $\begin{array}{l}\text { (1) Intermediate } \\
\text { acid } \rightarrow \text { acid } \\
\text { (2) Weakly peraluminous } \\
\text { (3) Shoshonite series } \\
\text { (4) Low-high } \\
\text { differentiation }\end{array}$ \\
\hline $\begin{array}{l}\text { Trace element } \\
\text { geochemical } \\
\text { features }\end{array}$ & $\begin{array}{l}\text { Medium and high } \\
\sum \mathrm{REE} \text {, weakly } \\
\text { dipping-right "V"-shape } \\
\text { rare-earth curve, negative } \\
\text { Eu anomaly. Enrichment } \\
\text { in } \mathrm{K}, \mathrm{Th}, \mathrm{U} \text {, and } \mathrm{Rb} \text {, and } \\
\text { deficit in } \mathrm{Ba}, \mathrm{Sr}, \mathrm{P}, \mathrm{Nb} \text {, } \\
\mathrm{Ta} \text {, and Ti, etc. From } \\
\text { monzonitic granite to } \\
\text { syenogranite, } \sum \mathrm{REE}, \mathrm{Rb} \\
\text { content, and negative Eu } \\
\text { anomaly trend to increase, } \\
\text { and }(\mathrm{La} / \mathrm{Yb})_{\mathrm{N}} \text { ratio, } \mathrm{Sr} / \mathrm{Y} \\
\text { ratio and } \mathrm{Sr} \text { content trend } \\
\text { to decrease while deficit } \\
\text { in } \mathrm{Ba}, \mathrm{Nb}, \mathrm{Ta}, \mathrm{Sr}, \mathrm{P}, \mathrm{Eu} \text {, } \\
\text { and Ti, etc., trend to } \\
\text { enhance }\end{array}$ & $\begin{array}{l}\text { Medium and high } \\
\sum \mathrm{REE} \text {, weakly } \\
\text { dipping-right "V"-shape } \\
\text { rare-earth curve, negative } \\
\text { Eu anomaly. Enrichment } \\
\text { in } \mathrm{K}, \mathrm{Th}, \mathrm{U}, \text { and } \mathrm{Rb} \text {, and } \\
\text { loss in } \mathrm{Ba}, \mathrm{Sr}, \mathrm{P}, \mathrm{Nb}, \mathrm{Ta} \text {, } \\
\text { and Ti, etc. From quartz } \\
\text { diorite to syenogranite, } \\
\sum \mathrm{REE}, \mathrm{Rb} \text { content, and } \\
\text { negative Eu anomaly } \\
\text { trend to increase, and } \\
\text { (La/Yb) })_{\mathrm{N}} \text { ratio, Sr/Y ratio, } \\
\text { and } \mathrm{Sr} \text { content trend to } \\
\text { decrease while deficit in } \\
\mathrm{Ba}, \mathrm{Nb}, \mathrm{Ta}, \mathrm{Sr}, \mathrm{P}, \text { Eu, and } \\
\mathrm{Ti}, \text { etc., trend to enhance }\end{array}$ & $\begin{array}{l}\text { Medium and high } \\
\sum \text { REE, weakly } \\
\text { dipping-right rare-earth } \\
\text { curve, negative Eu } \\
\text { anomaly. Enrichment in } \\
\mathrm{K}, \mathrm{Th}, \mathrm{U} \text {, and } \mathrm{Rb} \text {, and } \\
\text { deficit in } \mathrm{Ba}, \mathrm{Sr}, \mathrm{P}, \mathrm{Nb} \text {, } \\
\mathrm{Ta} \text {, and Ti, etc. From } \\
\text { volcanic rock to } \\
\text { subvolcanic rock, } \\
\sum \mathrm{REE}, \mathrm{Rb} \text { content, } \\
\text { negative Eu anomaly, and } \\
\text { loss in } \mathrm{Ba}, \mathrm{Nb}, \mathrm{Ta}, \mathrm{Sr}, \mathrm{P} \text {, } \\
\text { and Ti, as well as } \\
(\mathrm{La} / \mathrm{Yb})_{\mathrm{N}} \text { ratio, all trend } \\
\text { to lower }\end{array}$ \\
\hline $\begin{array}{l}\text { Type of } \\
\text { formation } \\
\text { causes }\end{array}$ & I-type granite & I-type granite & I-type granite \\
\hline $\begin{array}{l}\text { Magmatic } \\
\text { source }\end{array}$ & $\begin{array}{l}\text { Mainly remodification of } \\
\text { ancient crust materials, } \\
\text { and a handful of } \\
\text { lithospheric mantle } \\
\text { materials of Yangtze } \\
\text { block }\end{array}$ & $\begin{array}{l}\text { Mixture of materials in } \\
\text { lithospheric mantle of } \\
\text { Yangtze block and } \\
\text { ancient crust }\end{array}$ & $\begin{array}{l}\text { Mixture of materials in } \\
\text { lithospheric mantle of } \\
\text { Yangtze block and } \\
\text { ancient crust }\end{array}$ \\
\hline $\begin{array}{l}\text { Magmatic } \\
\text { evolution }\end{array}$ & $\begin{array}{l}\text { Differentiation } \\
\text { crystallization } \rightarrow \text { partial } \\
\text { melting }\end{array}$ & Partial melting & Partial melting \\
\hline $\begin{array}{l}\text { Formation } \\
\text { time limit } \\
\text { (Ma) }\end{array}$ & $145.1-125.0$ & $130.5-127.7$ & $135.2-125.4$ \\
\hline Metallogenesis & $\begin{array}{l}\text { Skarn-type } \mathrm{Zn}-\mathrm{Fe} \\
\text { polymetallic and fluorite; } \\
\text { quartz fine-vein tungsten; } \\
\text { hydrothermal vein-type } \\
\text { fluorite, } \mathrm{Sb}\end{array}$ & & $\begin{array}{l}\text { Volcanic-subvolcanic } \\
\text { hydrothermal } \mathrm{Zn}-\mathrm{Pb} \text {, } \\
\text { fluorite mineralization, } \\
\text { Uranium? }\end{array}$ \\
\hline
\end{tabular}

$\left(\mathrm{K}_{1} s\right)$, and Hengshan Formation $\left(\mathrm{K}_{1} h s\right)$ of lower volcanic rock series Jiande Group, and a handful of Zhongdai Formation $\left(\mathrm{K}_{2} z\right)$ of upper volcanic rock-system Qujiang Group, and in Jiande Group, the zircon U-Pb age is $134-115 \mathrm{Ma}(\mathrm{Li}$ et al. 2011). Overall, the period of lower volcanic rock series in Tianmu Mount and Shouchang, Jiande, northwest Zhejiang, is similar to the time limit for eruption of volcanic rock in its northwest neighborhood area, the middle and lower Yangtze River, (which is $135-123$ Ma in Early Cretaceous) (Zhou et al. 2011). 

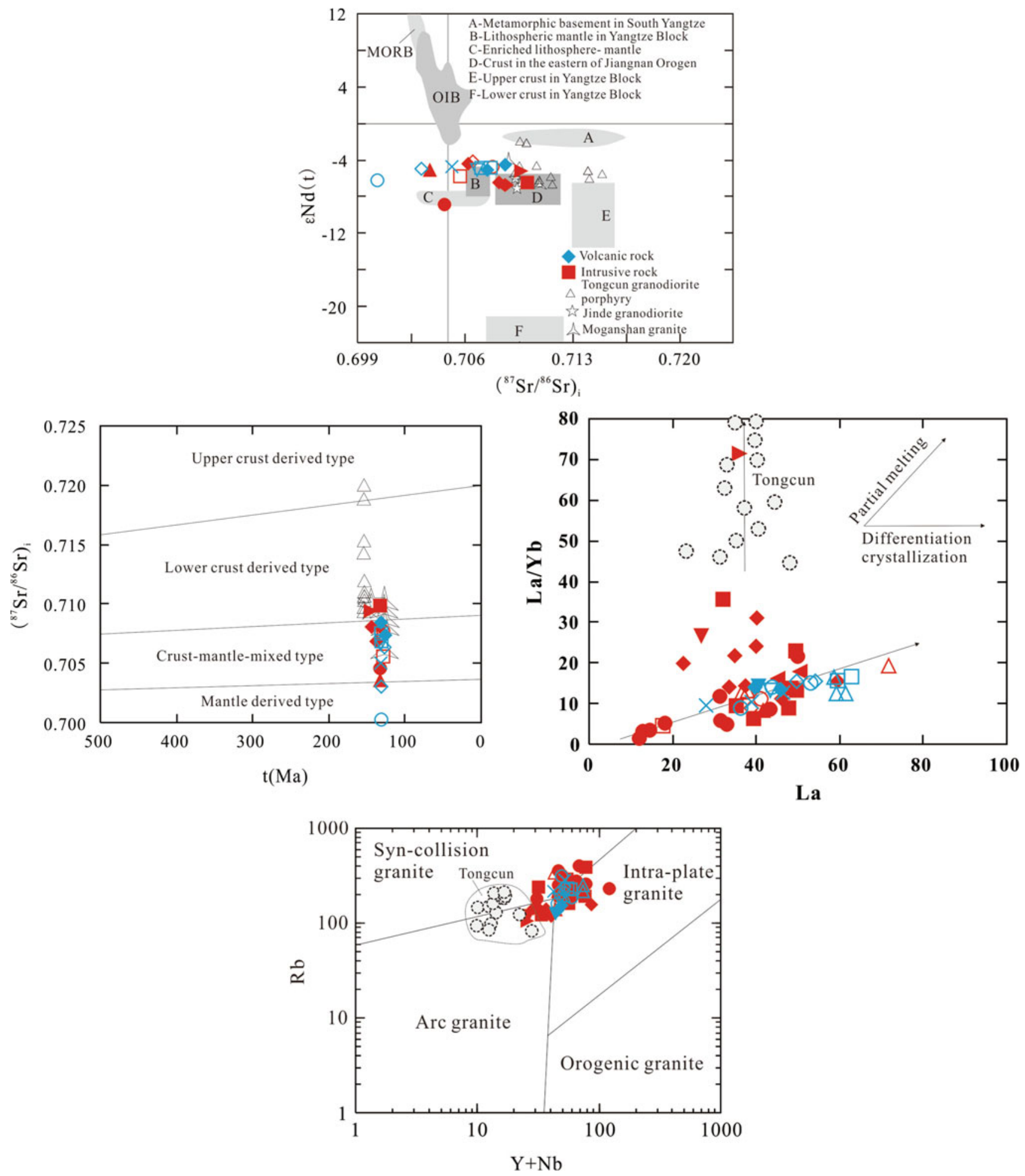

Fig. 3.88 Geochemical features and discrimination diagrams for magmatite in the survey area and neighboring areas

In Zhejiang Province, the lower and upper volcanic rock series can be divided into three volcanic activity cycles, the lower volcanic rock series corresponds to cycle \#I and \#II while the upper volcanic rock series corresponds to cycle
\#III (Yu et al. 2001; Yan et al. 2005). According to existing statistic chronological data, the period of the eruption of the lower volcanic rock series in Zhejiang is the beginning of Early Cretaceous (Fig. 3.89). In northwest Zhejiang, 


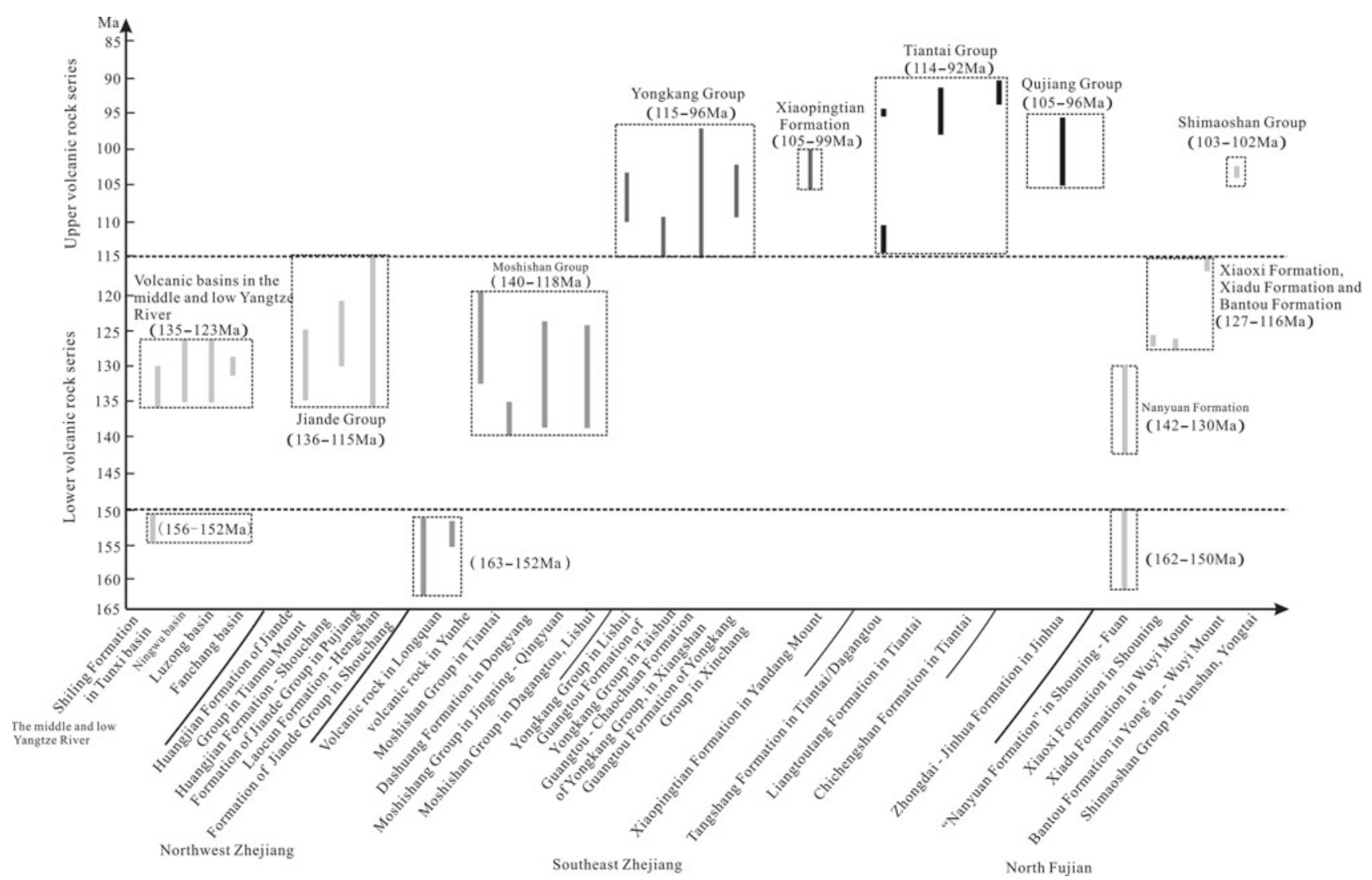

Fig. 3.89 Distribution of eruption time limits of volcanic rocks in Zhejiang and neighboring areas

volcanic rock horizons are Laocun Formation and Huangjian Formation of Cycle \#I, and Shouchang Formation and Hengshan Formation of Cycle \#II, of Jiande Group, for which the time limit of eruption concentrates at 136$115 \mathrm{Ma}$. In southeast Zhejiang, volcanic rock horizons are Dashuang Formation, Gaowu Formation and Xishantou Formation of Cycle \#I, and Chawan Formation, Jiuliping Formation, and Zhucun Formation of Cycle \#II, of Jiande Group, for which the time limit of eruption concentrates at 140-118 Ma. Volcanic rocks of Yongkang Group, Qujiang Group, and Tiantai Group of the upper volcanic rock series are erupted in 115-92 Ma, the end of Early Cretaceous-the beginning of Late Cretaceous.

In Fujian Province, of the lower volcanic rock series of Late Mesozoic, Nanyuan Formation volcanic rock is the most widely distributed rock types, with large era span, i.e., the end of Late Jurassic-the beginning of Early Cretaceous (Regional Geology in Fujian 2011), and the representative age of volcanic rock is 162.3-149.8 Ma (Late Jurassic) and 142.3130.1 Ma (Early Cretaceous) (Xing et al. 2008), and the age of volcanic rock in Xiadu Formation, Bantou Formation, and Xiaoxi Formation of the lower volcanic rock series is 127$116 \mathrm{Ma}$; the age of volcanic rock in Shimaoshan Group of the upper volcanic rock series is 103-102 Ma. Regarding the tectonic setting of Late Jurassic volcanic rock in Nanyuan Formation, previous research determined that it formed under a different tectonic setting compared that under which the Early Cretaceous volcanic rock and both are products, respectively, before and after the end of great transformation of the tectonic regime in later Mesozoic (Xing et al. 2008; Li et al. 2009), and it is unsuitable to include the Late Jurassic volcanic rock in the lower volcanic rock series (Duan et al. 2013). Recently, some Late Jurassic volcanic rock strata were also discovered in Zhejiang and Anhui, for instance, Shiling Formation in Tunxi, south Anhui (154.7 Ma, Yu et al. 2016; 156-152 Ma, Tang et al. 2016), Huangjian Formation in Shouchang, north Zhejiang (150.9 Ma, Li et al. 2011), Dashuang Formation in Dagangtou, Lishui, southeast Zhejiang (155-152 Ma, Zhejiang Institute of Geological Survey 2013), and in Longquan (162.7-148.7 Ma, Zhejiang Institute of Geological Survey 2017). All of these ages indicate a volcanic eruption event happened in South China in Late Jurassic (163-150 Ma) but with a small scale, which may be a prelude of a large-scale volcanic activities of Early Cretaceous, or product of volcanic activities under different tectonic settings, which should be further researched in the future.

By combining comparative analysis on regional strata and chronology, it is known that Late Mesozoic volcanic activity 
in Zhejiang and Fujian should begin in $162 \mathrm{Ma}$ (Mid to Late Jurassic); the Early Cretaceous lower volcanic rock series erupts in some 142-118 Ma in large scale, reaching peak in 135-125 Ma, which is a set of high K calc-alkaline volcanic eruptive rocks, most of which are intermediate acidic-acidic. While the upper volcanic rock series volcanic activities weaken significantly in 115-92 Ma, a set of basalt-rhyolite dual-peak combination and red layer sedimentary rocks; the regional unconformable surface between the lower and upper volcanic rock series (i.e., Minzhe movement) should have formed in about 118-115 Ma.

\section{References}

Blevin PL (2003) Metallogeny of granitic rocks. Gemoc Macquarie University. In: Magmas to mineralisation: The Ishihara symposium. Geoscience Australia, Canberra, Australia, pp 1-4

Chen JF, Jiang BM (1999) $\mathrm{Nd}, \mathrm{Sr}, \mathrm{Pb}$ isotope tracing and crustal evolution in southeastern China. In: Zheng YF (ed) Chemical geodynamics. Science Press, Beijing, pp 262-287 (in Chinese with English abstract)

Chen PR, Hua RM, Zhang BT et al (2002) Early Yanshanian Post-Orogenic Granitoids in the Nanling Region: petrological Constraints and geodynamic settings. Sci China (Ser D) 45 (8):756-768

Dong SW, Zhang YQ, Long CX, Yang ZY, Ji Q, Wang T, Hu JM, Chen XH (2007) Jurassic tectonic revolution in China and new interpretation of the Yanshan Movement. Acta Geol Sin 81 (11):1449-1461 (in Chinese with English abstract)

Duan Z, Xing GF, Yu MG, Zhao XL, Jin GD, Chen ZH (2013) Time sequence and geological process of Late Mesozoic volcanic activities in the area of Zhejiang-Fujian Boundary. Geol Rev 59 (3):454-469 (in Chinese with English abstract)

Feng ZH, Wang CZ, Wang BH (2009) Granite magma ascent and emplacement mechanisms and their relation to mineralization process. J Guilin Univ Technol 29(2):183-194 (in Chinese)

Fujian Institute of Geological Survey (2011) Fujian Regional Geology (in Chinese). National Geological Archives of China [distributor], 2018. http://www.ngac.org.cn/Data/FileList.aspx?MetaId= 43FBD60C736B3FF1E05341015A0AECA0\&Mdidnt=d00134772

Gao S, Qiu Y M, Ling W L, McNaughton NJ, Groves DI (2001) SHRIMP single zircon $\mathrm{U}-\mathrm{Pb}$ dating of the Kongling high-grade metamorphic terrain: Evidence for $>3.2 \mathrm{Ga}$ old continental crust in the Yangtze craton. Sci China (Ser D), 44(4):326-335

Gao YF, Yang ZS, Santosh M et al (2010) Adakitic rocks from Slab melt-modified mantle sources in the continental collision zone of Southern Tibet. Lithos 119(3-4):651-663

Guo ZF, Wilson M, Liu JQ (2007) Post-collisional adakites in South Tibet: products of partial melting of subduction-modified lower crust. Lithos 96(1-2):205-224

Hoskin PWO, Schaltegger U (2003) The Composition of Zircon and Igneous and Metamorphic Petrogenesis[J]. Rev Miner Geochem 53:27-62

Hou ZQ, Gao YE, Qu XM et al (2004) Origin of adakitic intrusives generated during mid-Miocene east-west extension in Southern Tibet. Earth Planet Sci Lett 220(1-2):139-155

Jiang YH, Zhao P, Zhou Q et al (2011) Petrogenesis and tectonic implications of Early Cretaceous S- and A-type granites in the northwest of the Gan-Hang rift, SE China. Lithos 121:55-73

Li XH (1993) Geochronological framework and isotope system constraints of crustal growth and tectonic evolution in South China.
Bull Mineral Petrol Geochem 3:113-115 (in Chinese with English abstract)

Li ZN, Quan H, Li ZT et al (2003) Mesozoic, Cenozoic igneous rocks and their deep processes in eastern China. Geological Publishing House, Beijing, pp 1-351(in Chinese)

Li XH, Li ZX, Li WX et al (2007) U-Pb zircon, geochemical and Sr$\mathrm{Nd}-\mathrm{Hf}$ isotopic constraints on age and origin of Jurassic I and A-Type granites from Central Guangdong, SE China: a major igneous event in response to foundering of a subducted flat-slab? Lithos 96:186-204

Li LM, Sun M, Xing GF et al (2009) Two late Mesozoic volcanic events in Fujian Province: constraints on the tectonic evolution of southeastern China. Int Geol Rev 51:216-251

Li XH, Chen SD, Luo JH, Wang Y, Cao K, Liu L (2011) LA-ICP-MS $\mathrm{U}-\mathrm{Pb}$ isotope chronology of the single zircons from early Cretaceous Jiande Group in Western Zhejiang, SE China: significances to stratigraphy. Geol Rev 57(6):825-836 (in Chinese with English abstract)

Li ZL, Zhou J, Mao JR, Yu MG, Li YQ, Hu YZ, Wang HH (2013) Age and geochemistry of the granitic porphyry from the northwestern Zhejiang Province, SE China, and its geological significance. Acta Petrol Sinica 29(10):3607-3622 (in Chinese with English abstract)

Ma CQ, Yang KG, Tang ZH et al (1994) Magma dynamics of granitetheory and methodology as well as analysis of granite in East Hubei. China University of Geosciences Press, Wuhan (in Chinese)

Mao JR, Li ZL, Ye HM (2014) Mesozoic tectono-magmatic activities in South China: retrospect and prospect. Sci China Earth Sci 57:2853-2877

Rui ZY, Zhang HT, Li N, Wang LS (1991) On the multiple emplacement of the granitic magma and the multiple minerogenetic models. Acta Petrol Mineral 10(2):97-103 (in Chinese with English abstract)

Sun SS, McDonough WF (1989) Chemical and isotopic systematics of oceanic basalts: implication for mantle composition and processes. In: Saunder AD, Norry MJ (eds) Magmatism in the ocean basins. Geol Soc Spec Publ 42:313-345

Tang S, Xu XB, Yuan YM (2016) Geochemistry and geochronology of the volcanic rocks from Tunxi basin in southern Anhui and their tectonic significance. Acta Petrol Mineral 35(2):177-194 (in Chinese with English abstract)

Turner SP, Foden JD, Morrison RS (1992) Derivation of some A-Type magmas by fractionation of basaltic magma: an example from the Padthaway Ridge, South Australia. Lithos 28:151-179

Vavra G, Schmid R, Gebauer D (1999) Internal morphology, habit and $\mathrm{U}-\mathrm{Th}-\mathrm{Pb}$ microanalysis of amphibolite-to-granulite facies zircons: geochronology of the Ivrea Zone (Southern Alps). Contrib Miner Petrol 134:380-404

Wang YL, Wang Y, Zhang Q, Jia XQ, Hang S (2004) The geochemical characteristics of Mesozoic intermediate-acid intrusives of the Tongling area and its metallogenesis-geodynamic implications. Acta Petrol Sinica 20(2):325-338 (in Chinese with English abstract)

Wang XL, Shu XJ, Xu XS et al (2012) Petrogenesis of the early Cretaceous adakite-like porphyries and associated basaltic andesites in the eastern Jiangnan orogen southern China. J Asian Earth Sci 61:243-256

Wang YJ, Fan WM, Zhang GW et al (2013) Phanerozoic tectonics of the South China Block: key observations and controversies. Gondwana Res 23:1273-1305

Whalen JB, Currie KL, Chappell BW (1987) A-Type granites: geochemical characteristics, discrimination and petrogenesis. Contrib Mineral Petrol 95:407-419

Wu LS (1998) Type of magmatic emplacement in relation to mineralization in Jiujiang Ruichang District, Jiangxi Province. Min Deposits 17(1):36-45 (in Chinese with English abstract)

Xia LQ, Xia ZC, Xu XY, Li XM, Ma ZP, Wang LS (2004) Carboniferous Tianshan igneous megaprovince and mantle plume. 
Reg Geol China 23(9-10):903-910 (in Chinese with English abstract)

Xing GF, Lu QD, Chen R, Zhang ZY, Nie TC, Li LM, Huang JL, Lin M (2008) Study on the ending time of Late Mesozoic tectonic regime transition in South China_comparing to the Yanshan Area in North China. Acta Geol Sin 82(4):451-463 (in Chinese with English abstract)

Xing GF, Chen R, Yang ZL, Zhou YZ, Li LM, Jiang Y, Chen ZH (2009) Characteristics and tectonic setting of Late Cretaceous volcanic magmatism in the coastal Southeast China. Acta Petrol Sinica 25(1):77-91 (in Chinese with English abstract)

Xue HM, Wang YG, Ma F, Wang C, Wang DE, Zuo YL (2009) The Huangshan A-type granites with tetrad REE: constraints on Mesozoic lithospheric thinning of the southeastern Yangtze craton? Acta Geol Sin 83(2):247-259 (in Chinese with English abstract)

Yan TZ, Yu YW, Chen JF, Xu XM, Wang JG, Cai ZH, Dong YH (2005) Nd-Sr isotope features of Cretaceous volcanic rocks in northwestern Zhejiang. Chin Geol 32(3):417-423 (in Chinese with English abstract)

Yu YW, Xu BT, Chen JF, Dong CW (2001) Nd isotopic systematics of the Late Mesozoic VOLCANIC Rocks from Southeastern Zhejiang Province, China: implications for stratigraphic study. Geol J China Univ 7(1):62-69 (in Chinese with English abstract)

Yu XQ, Chen ZW, Liu X, Ji X, Zhou SZ, Yang XP (2016) LA-ICP-MS zircon age of volcanic rock of Shiling Formation in Tunxi area, south Anhui, and redetermination of its epoch. Geol Bull China 35 (1):175-180 (in Chinese with English abstract)

Zhang HF, Goldstern SL, Zhou XH et al (2008) Evolution of subcontinental lithospheric mantle beneath eastern China: Re-Os isotopic evidence from mantle xenoliths in Paleozoic kimberlites and Mesozoic basalts. Contrib Mineral Petrol 155:271-293

Zhang JJ, Shi GH, Tong GS, Zhang ZY, Liu H, Wu RT, Chen L (2009) Geochemistry and geochronology of copper and polymetal-bearing volcanic rocks of the erhuling formation in Xujiadun, Zhejiang Province. Acta Geol Sin 83(6):791-799 (in Chinese with English abstract)

Zhang BT, Wang KX, Ling HF, Wu JQ (2012) Zircon U-Pb and whole-rock $\mathrm{Rb}-\mathrm{Sr}$ chronology, $\mathrm{Sr}-\mathrm{Nd}-\mathrm{O}$ isotopes and petrogenesis of the mogaoshan granite pluton in the Zhejiang Province. Bull Mineral Petrol Geochem 31(4):347-353 (in Chinese with English abstract)
Zhejiang Institute of Geological Survey (2013) The regional geological survey of Shuangxi Town, Lishui City, Dagangtou Town and Zhangcun map sheets on a scale of 1,50,000 in Zhejiang (in Chinese). National Geological Archives of China [distributor], $2018 . \quad$ http://ngac.org.cn/Data/FileList.aspx?MetaId= 43FBD60C7B413FF1E05341015A0AECA0\&Mdidnt=d00135959

Zhejiang Institute of Geological Survey (2017) The regional geological and mineral resources survey of Xuanhu and Ruiyang map sheets on a scale of 1,50,000 in Zhejiang (in Chinese)

Zheng JM, Xie GQ, Chen MH, Wang SM, Ban CY, Du JL (2007) Pluton emplacement mechanism constraint on skarn deposit: a case study of skarn Fe deposits in Handan-Xingtai area. Min Deposits 26 (4):481-486 (in Chinese with English abstract)

Zheng YF, Xiao WJ, Zhao GC (2013) Introduction to tectonics of China. Gondwana Res 23:1189-1206

Zhou TF, Fan Y, Yuan F, Zhang LJ, Ma L, Qian B, Xie J (2011) Petrogensis and metallogeny study of the volcanic basins in the Middle and Lower Yangtze metallogenic belt. Acta Geol Sin 85 (5):712-730 (in Chinese with English abstract)

Zhou J, Jiang YH, Zeng Y, Ge WY (2013) Zircon U-Pb age and Sr, $\mathrm{Nd}$, Hf isotope geochemistry of Jingde pluton in eastern Jiangnan orogen, South China. Geol China 40(5):1379-1391 (in Chinese with English abstract)

Zhou J, Jiang YH, Ge WY (2014) High Sr/Y jingde pluton in the Eastern Jiangnan orogen, South China: formation mechanism and tectonic implications. Acta Geol Sin 88(1):53-62 (in Chinese with English abstract)

Zhu DC, Mo XX, Wang LQ et al (2009) Petrogenesis of highly fractionated I-Type granites in the Chayu Area of Eastern Gangdese, Tibet: constraints from Zircon U-Pb geochronology, geochemistry and Sr-Nd-Hf isotopes. Sci China (Ser D: Earth Sci) 52(9):1223-1239

Zhu G, Niu ML, Xie CL et al (2010) Sinistral to normal faulting along the Tan-Lu Fault Zone: evidence for geodynamic switching of the East China continental margin. J Geol 118:277-293

Zhu YD, Ye XF, Zhang DH, Wang KQ, Wang CS, Yin XB (2014) Petrochemistry, SHRIMP dating and $\mathrm{Sr}-\mathrm{Nd}$ isotopic constraints on the origin of the Kaihua porphyry Mo $(\mathrm{Cu})$ deposit, Zhejiang Province. Earth Sci Front 21(4):221-234 (in Chinese with English abstract)
Open Access This chapter is licensed under the terms of the Creative Commons Attribution 4.0 International License (http:// creativecommons.org/licenses/by/4.0/), which permits use, sharing, adaptation, distribution and reproduction in any medium or format, as long as you give appropriate credit to the original author(s) and the source, provide a link to the Creative Commons license and indicate if changes were made.
The images or other third party material in this chapter are included in the chapter's Creative Commons license, unless indicated otherwise in a credit line to the material. If material is not included in the chapter's Creative Commons license and your intended use is not permitted by statutory regulation or exceeds the permitted use, you will need to obtain permission directly from the copyright holder.

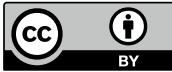

